Aino Kallas

Negotiations with Modernity

Edited by

Leena Kurvet-Käosaar and Lea Rojola 
The Finnish Literature Society (SKS) was founded in 1831 and has, from the very beginning, engaged in publishing operations. It nowadays publishes literature in the fields of ethnology and folkloristics, linguistics, literary research and cultural history.

The first volume of the Studia Fennica series appeared in 1933. Since 1992, the series has been divided into three thematic subseries: Ethnologica, Folkloristica and Linguistica. Two additional subseries were formed in 2002, Historica and Litteraria. The subseries Anthropologica was formed in 2007.

In addition to its publishing activities, the Finnish Literature Society maintains research activities and infrastructures, an archive containing folklore and literary collections, a research library and promotes Finnish literature abroad.

STUDIA FENNICA EDITORIAL BOARD

Markku Haakana, professor, University of Helsinki, Finland

Timo Kaartinen, professor, University of Helsinki, Finland

Kimmo Rentola, professor, University of Turku, Finland

Riikka Rossi, postdoctoral research fellow, University of Helsinki, Finland

Hanna Snellman, professor, University of Jyväskylä, Finland

Lotte Tarkka, professor, University of Helsinki, Finland

Tuomas M. S. Lehtonen, Secretary General, Dr. Phil., Finnish Literature Society

Johanna Ilmakunnas, secretary of the board, Dr. Phil., Finnish Literature Society, Finland

Editorial OfFice

SKS

P.O. Box 259

FI-00171 Helsinki

www.finlit.fi 


\section{Aino Kallas}

Negotiations with Modernity

Edited by Leena Kurvet-Käosaar and Lea Rojola

Finnish Literature Society $\cdot$ Helsinki 


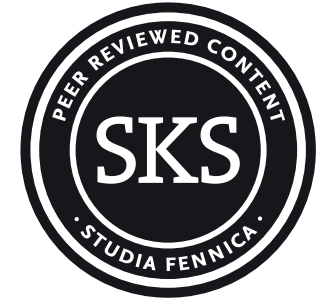

Studia Fennica Litteraria 4

The publication has undergone a peer review.

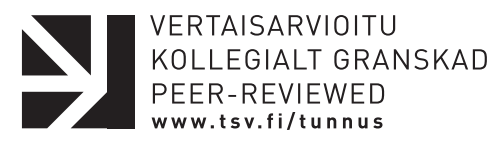

The open access publication of this volume has received part funding via a Jane and Aatos Erkko Foundation grant.

(C) 2011 Leena Kurvet-Käosaar, Lea Rojola and SKS

License CC-BY-NC-ND 4.0. International

A digital edition of a printed book first published in 2011 by the Finnish Literature Society. Cover Design: Timo Numminen EPUB Conversion: Tero Salmén

ISBN 978-952-222-260-2 (Print)

ISBN 978-952-222-750-8 (PDF)

ISBN 978-952-222-787-4 (EPUB)

ISSN 0085-6835 (Studia Fennica)

ISSN 1458-5278 (Studia Fennica Litteraria)

DOI: http://dx.doi.org/10.21435/sflit.4

This work is licensed under a Creative Commons CC-BY-NC-ND 4.0. International License. To view a copy of the license, please visit http://creativecommons.org/licenses/by-nc-nd/4.0/

A free open access version of the book is available at http://dx.doi. org/10.21435/sflit.4 or by scanning this QR code with your mobile device. 


\section{Contents}

Leena Kurvet-KäosaAr And Lea Rojola

Introduction: Aino Kallas, Negotiations with Modernity 7

\section{Along the Trajectories of the New Woman}

TiINA KIRss

Scheherazade's Whisper

Contrapuntal Readings of Aino Kallas and Isak Dinesen 18

LEA RoJola

"And she felt the desire to speak"

Aino Kallas, Maie Merits, and the Female Voice 35

Kukku Melkas

From Apocalypse to the New Paradise

Early Ecological Thinking and Aino Kallas' Work in the 1920s 53

\section{Crossing Modernity's Master Discourses}

MirJam Hinrikus

Decadent Modernism and the Imprint of Taine in Aino Kallas'

Young Estonia: Portraits and Trajectories 66

LeEna Kurvet-KäOsaAR

"The vitality of primeval peasant blood"

The Hereditary Potential of Estonians in the Work of Aino Kallas 91

SilJa VUORIKuru

Following the Traces of Unknown Bathseba 111

LIINA LUKAS

Goethe, Master!

Reading Goethe with Aino Kallas and her Contemporaries 130

REIN UNDUSK

Does Love Have An Essence?

Existentialist Remarks on Aino Kallas' Prose Ballads 142 


\section{Life on the Borders}

SirJe Olesk

Aino Kallas on the Boundaries of Finland, Estonia and the World 162

Ritva Hapuli

"The suitcases in my room"

Aino Kallas as a Traveller and a Travel Writer 181

MAARIT LESKELÄ-KäRKI

Songs of Comfort and Lamentation

Autobiographical Connections in the Texts of the Ageing Aino Kallas 198

Kai Stahl and Tutta Palin

The Aino Kallas Iconography

Interactive Self-Presentation 215

Contributors 252 


\section{Introduction}

\section{Aino Kallas, Negotiations with Modernity}

Aino Kallas (neé Aino Julia Maria Krohn) was born on August 2, 1878 and, according to her own words, had an artist's "multicolored pulse in her blood" that implied the possibility of one day "flying like smoke, like wind" beyond the material borders of her daily self $(1920,39)$ for as long as she could remember. Envisioning herself as an artist in an early autobiographical work Katinka Rabe (1920) that focuses on her childhood, Kallas was at the time of completing the novel still at the beginning of her self-realization as an artist; she couldn't have foreseen the scope and impact of her work in the future. Yet this elaboration of a creative credo constitutes an important axis that informs her journey of following a vocation in an environment not always hospitable or accommodating to her ambitions. Today, the varied and rich legacy of Aino Kallas (1878-1956) that consists of novels, short stories, plays, literary and cultural criticism, memoirs, biographies, diaries, and letters places her firmly among the outstanding writers and intellectuals of the first half of the $20^{\text {th }}$ century in the (modernist) literary canon of Finland and Estonia.

In October 2008, the 130th anniversary of Aino Kallas' birth was celebrated at the Estonian Literary Museum in Tartu with a conference that focused on her engagements with "the modern" on the Estonian and Finnish cultural scene at the beginning of the $20^{\text {th }}$ century - the two cultural contexts that played a central role in her life. Aino Kallas once noted in her diary that she has no one country to call her own, "she belongs to the world"1 $(1956,182)$. Here, Kallas does not so much celebrate cosmopolitan sentiment but voices a feeling of loss for not being able to fully belong to one culture - or the failure of any one culture to recognize her as one of its own. The feeling of loss is understandable, because Kallas left Finland very early, at the age of 22 when she in 1900 married an Estonian scholar and man of letters Oskar Kallas and, via St. Petersburg, the young couple moved to Estonia. This had a significant impact on the authorship of Aino Kallas. From 1903 on, she wrote only two works in which the events do not occur in Estonia. And yet, the works are written in Finnish and in that sense she dwelled in two places, two countries and, at times, felt that neither of them understood her literary art.

However, from a wider perspective of the artistic and intellectual legacy of Aino Kallas, such identification also testifies to her intellectual and aes- 
thetic grasp of modernity and her varied and rich modes of engagement with it. Compared to "old Europe", Estonia and Finland were two young cultures at the beginning of the $20^{\text {th }}$ century devoted not only to the process of advancing national culture, but also tuned in to absorbing and reflecting upon wider international cultural developments. For Aino Kallas, following and participating in the cultural debates in Estonia and Finland was a priority. At the same time, however, her whole oeuvre is a constant process of negotiation between her more immediate contexts and the leading conceptual frameworks of art, aesthetics, geniality, knowledge, subjectivity, race, sexuality, nature, etc., circling in Europe at the end of the 19th century and the beginning of the $20^{\text {th }}$ century.

In the re-conceptualization of Finnish and Estonian modernism and the literary heritage of fin de siècle, Aino Kallas is today considered to occupy a significant position (see, e.g., Rojola 1992, 132-150; Olesk 1999, 324-326; Kurvet-Käosaar 2006; Leskelä-Kärki 2006; Melkas 2006; Leskelä-Kärki, Melkas and Hapuli 2009). However, early research on Kallas treats the question of modernism or modernity in relation to her work with considerable reservations. Kai Laitinen, who wrote the first monograph of Kallas, argues that because of the historical themes in Kallas' work, her place is firmly outside the modernist literary canon. This is due to the fact that the concept of modernism is quite narrow in Laitinen's study. When feminist scholars began approaching the work of Kallas with more flexible concepts of modernism and modernity, the result was quite the opposite: Kallas' fiction, life-writings and essayistic work inscribe important aspects of the kind of engagement with modernity that has been vital to women authors all over to Europe. In particular, in the first decades of the $20^{\text {th }}$ century, many modernist women authors tried to imagine a new female subject through various kinds of myths and utopias, and Kallas is one among them. Such imaginative work produced a new female subject that was also, in a pronounced manner, a bodily and hence a sexual subject, and many central themes of Kallas' fiction as well as her other writings confirm such position (Kurvet-Käosaar 2006, Lappalainen 1995, Rojola 1994). The extensive scope of the new kind of knowledge that emerged within the process of engagement with myths and history of women authors of the period, including the work of Aino Kallas, can be viewed as a new epistemology within the Western ways of knowing (Melkas 2006). These re-evaluations place Aino Kallas firmly at the heart of the new worldview that emerged gradually at the end of the $19^{\text {th }}$ and the beginning of the $20^{\text {th }}$ century.

For Aino Kallas, being a modern individual was never an aim in itself; rather, her engagement with central intellectual and cultural debates of her times was a means of producing and assembling for herself a space of existence, "a room of her own" that she could inhabit creatively and with a sense of agency - as a woman (with its varied and often conflicting roles) and as an artist. Aino Kallas is not alone in her attempt to elaborate an existential stance that would enable and support female subjectivity and creativity and cater for the needs of a woman intellectual in an era when misogynistic visions of culture and society, perceptions of art, and genius abounded. Comparable strategies and manoeuvres can be detected in the 
ways in which many early 20th century women of letters came to voice a "critique of modern civilization", ultimately leading them to "remarkable new vision[s]" (Hill 1999, 1-2). (See, e.g., Benstock 1987, Gilbert and Gubar 1987, 1989, Felski 1995, Podnieks 2000).

Although the interpretations of Kallas' fictional work in relation to the paradigm of modernism have played a crucial role in securing her a position in the literary canon of Finnish and Estonian modernism, the current collection is not limited to an analysis of aesthetic concerns and values, but places her work and life into the wider socio-cultural frameworks of her times. The traditional, dominantly male use of the paradigm of literary modernism has foregrounded, more or less exclusively, aesthetic and formal concerns. In the Anglo-American conceptualisations of modernism, influenced by the New Critics and T. S. Eliot's "doctrines of impersonality and of the objective correlative" (Hanson 1998, 203), literary works were carefully isolated from their wider cultural contexts, making it appear "blunt, banal, even gauche to discuss modernist writing as a critique of twentieth-century culture" (Dekoven 1992, 12). Challenging the view of transcendent art, feminist critics have made visible the extent to which modernist literature was "always embedded in particular social and ideological systems in which gender was a key element” (Hanson 1998, 204). Several feminist critics of modernism have highlighted the need to look for the implications of the modernist motto of "making it new" not only in women's texts but also in the ways they managed their lives and conceived themselves, placing emphasis on defiance of normative configurations of gender roles (see, e.g., Benstock 1986, 3; Hanscombe and Smyers 1987, 11; Podnieks 2000, 74).

Approaching the question of modernism and gender from the perspective of a cultural critic, Rita Felski calls into doubt the very usefulness of the concept of viewing it as a set of dominantly formal markers that makes it possible to view some literary texts as "embodying the truth of the modern Zeitgeist in a uniquely representative way" $(1995,26)$; she proposes, instead, to use a more flexible concept of modernity. Aiming at a wider gendered perspective of the modern period, Felski, as along with Ann Ardis, argues for the need to take into consideration not only a few "exemplary canonical [literary] texts" by women writers but also the impact of mass political movements and various aspects of popular culture such as fashion, consumer culture, journalism, as well as a radical constructions of feminine sexuality (Felski 1995, 27-28, Ardis 2003, 1). Felski also highlights the necessity to include in the analysis of women's experience of modernity women belonging to different strata of society and a concern for the everyday and the mundane, the areas of women's lives usually dismissed as insignificant $(1995,28)$.

Though opinions vary both on dating modernity as well as its implications in terms of progress and development, it undoubtedly belongs among the key concepts of Western culture and history. The current collection strives to make visible the manner of Aino Kallas' engagement with modernity, emphasizing her significance not only to the cultural contexts and artistic and intellectual horizons of Finland and Estonia, but also on a wider scale also those of Scandinavia and Europe. There is no doubt that 
Aino Kallas was throughout her life intensely tuned toward building a familiarity with the key debates over culture, aesthetics, gender, sexuality, race, and environment in Europe and in Scandinavia. Her wide horizon of knowledge was exemplary for a woman of her time, and her observations of topical intellectual and aesthetic issues of the day (that in overt format can be found in her cultural criticism and in more covert manner her fictional work) were sharp and insightful.

Aino Kallas' negotiations with modernity can be tentatively divided into various clusters of thought. Questions of the new aesthetics emerged in relation to the Young Estonia movement, in Kallas' search for her own poetics of writing, and in the interrelationship and tensions between aesthetic and experiential concerns. The role of Aino Kallas as a 'cultural ambassador', mediating and introducing Estonian culture in Finland and vice versa, as well as her attempts to place Estonian and Finnish culture into wider European frameworks, relate to aesthetic concerns but also reflect on the problem of (cultural) belonging in Aino Kallas' own life. Aesthetic matters in turn are intertwined with wider socio-cultural concerns and intellectual developments that find reflection in Aino Kallas' fiction, in her life-writings, and in her work as a cultural critic. Demonstrating a familiarity with the thought of many leading European intellectuals of the period, the work of Aino Kallas engages, for example, with the perceptions of culture and humanity of more general nature (Friedrich Nietzsche, Otto Weininger, Georg Simmel), sexuality (Sigmund Freud, Cesare Lomboso, Richard von Krafft-Ebbing), race (Arthur de Gobineau, Hippolyte Taine, Auguste Morel), the interrelationship between nature and civilization (Elin Wägner, Rosa Mayreder), and women's emancipation, in particular Scandinavian feminist thought (Ellen Key, Minna Canth, Laura Marholm).

Although Aino Kallas is most well known in Finland and in Estonia, her work has also been translated into English, Swedish, Norwegian, Dutch, Italian, German, Hungarian and Russian. In 1922 Aino Kallas moved to London to accompany her husband who assumed the post of the Estonian Ambassador to the United Kingdom. The Kallas family stayed in London for 12 years, and it was during this period that Aino Kallas wrote her most influential work, the novels Barbara von Tisenhusen (1923), Reigin Pappi [The Rector of Reigi] (1926), and Sudenmorsian [The Wolf's Bride] (1928). She also gradually developed an international reputation, and translations of her work started appearing in different languages. Only two years after moving to London, two volumes of her work were translated into English by Alex Matson: the short story collection The White Ship (1924) and a collection of two novels, Barbara von Tisenhusen and Reigin Pappi published under the title Eros the Slayer (1924), followed by The Wolf's Bride that was published in 1930.

This current collection, the first in English on the work of Aino Kallas, reflects on the processes of Aino Kallas' engagement with modernity from various viewpoints and thematic angles, focusing on her novels and short stories, the previously unknown play "Bathseba", diaries, letters, cultural criticism, and visual images of her. Although the objective of the collection is not only to present Aino Kallas' work and life from the perspective 
of feminist criticism, most contributions make visible the genderedness of different discourses of modernity, and Aino Kallas' awareness of such bias as well as the importance for her to relate to aesthetic and socio-cultural matters and reflect upon her own life as a woman. Such perspective, however, rarely comes to dominate the work of Aino Kallas but rather forms an ever-present level of engagement and reflection among a range of issues concerning modernity.

The articles in the first section of the volume, titled "Along the Trajectories of the New Woman", concentrate on Aino Kallas' work as part of a process of envisioning new female and feminist aesthetics modes of knowledge. Tiina Kirss offers a comparative contrapuntal reading of the fiction of Aino Kallas in relation to that of an internationally renowned Danish woman author Isak Dinesen (Karen Blixen), focusing on dialectical, uneasy, and unconventional relations with "modernisms" in the literary cultures of the primary audiences of the two authors. As Kirss argues, Dinesen in her "stylised Gothic" stories and Kallas in her historical fictions take stances on an exoticized past: despite many of the labels each have warranted in literary histories, neither is a "modern" writer only. Lea Rojola focuses on issues of the female voice within the Western literary tradition through an analysis of Aino Kallas' short story "Lasnamäen valkea laiva” [The White Ship] (1913). Concentrating on the theme of the female voice and a woman's right to speak on three levels, Rojola interprets the short story in relation to the process of Aino Kallas seeking a voice of her own as an author, the implications of the cultural figure of the speaking woman for her own community, and within the wider context of the Western literary tradition, where the female voice is usually interpreted as a symbol of disastrous power. Kukku Melkas presents Aino Kallas' prose work in connection with the early (feminist) ecological thought that emerged in Scandinavia between the two World Wars, examining Kallas' exploration of the gendered culture/nature dualism and her search for a new kind of relationship between woman, man, and nature that can be seen as a novel way of thinking about nature and environment - which can today be seen as part of ecological thought.

Five articles in the section "Crossing Modernity's Master Discourses" trace Kallas' engagement with cultural debates of central importance in late $19^{\text {th }}$ and early $20^{\text {th }}$ century Europe concerning decadent modernism, theories of race and heredity, and the relationship between Finnish literary symbolism and Kallas' unpublished play Bathseba. The section also extends the application possibilities of the concept of modernity beyond the more common temporal frame of late $19^{\text {th }}$ and early $20^{\text {th }}$ century, focusing on Kallas' reading of Goethe and offering a conceptualisation of the fiction of Kallas within the framework of existentialism. The article by Mirjam Hinrikus highlights the role of Aino Kallas as a cultural critic via her collection of essays Nuori Viro. Muotokuvia ja suuntaviivoja [Young Estonia. Portraits and Trajectories] (1918), offering an in-depth analysis of the imprint of Hippolyte Taine on Kallas' explanations of Young Estonia's place in cultural history, particularly his insistence on contextualising literary texts in the cultural "moment" of their genesis. She also points out that an outstanding feature of the collection is the problem of (the excess of) modernity - of European 
culture having reached its peak and from there taking a plunge toward the over ripened impulses of decadence and degeneration. Leena KurvetKäosaar explores Aino Kallas' engagement with race and heredity debates of late 19th century and early 20th century Europe, focusing in particular on her representation, both in fiction and in life-writings, of the potential and limits of the Estonian race - highlighting in particular "the vitality of native peasant blood" as the foundation of high-quality Estonian culture and as a guarantee of the advancement of Estonians as a nation. Her fine reflection of the subject follows the main foci of the debate both in Europe at large (works of Darwin, Taine, Lombroso, Morel, etc.) as well as the Estonian highlights of that debate (Johannes Aavik's theory of 'reverse selection', Juhan Luiga's ideas on the Northern spirit, etc.).

Silja Vuorikuru's article focuses on Aino Kallas' unpublished verse drama Bathseba (1909) set in a biblical milieu, an exception in Kallas' oeuvre. The manuscript of the play, believed to be lost, was discovered by Vuorikuru in the Estonian Literary Museum in Tartu, Estonia, in February 2008. A comparison of Bathseba to Kallas' published works reveals that Bathseba as the main character notably resembles the ambivalent female figures of Kallas' later works, especially the heroines of the Eros the Slayer trilogy. Also, the conscious use of biblical pastiches, allusions, and quotations in Bathseba are distinctive in Kallas' published works. Liina Lukas looks at Goethe's impact on Aino Kallas' personality and literary development, in particular the process of objectification of subjective passions into a work of art. Kallas' strongest interest in Goethe coincides with a period of crisis in her personal life, as well as issues of artistic development. Lukas focuses on Goethe's role in these processes in the life of Aino Kallas, approaching the topic in a wider context of Goethe's reception in the early $20^{\text {th }}$ century European and Finnish culture, then proceeding with an analysis of Goethe's possible role in the artistic and personal development of Aino Kallas. Rein Undusk argues that tragic love can be considered a theme that fascinated Aino Kallas throughout her artistic career. Analysing Kallas' conception of love in the context of 19 th and 20th century existential thought, Undusk gives special attention to its religious undertones, which testify to the existence of certain Romantic ideals in Kallas' work. The tragedy of love in Kallas' masterpiece Eros the Slayer, always accompanied by a kind of religiously elevating experience, can be interpreted also as the writer's artistic quest for the existential feeling of life so characteristic of Romantic philosophy and, for example, of the first existentialist thinker Søren Kierkegaard.

The last section of this volume, titled "Life on the Borders", approaches the implications of modernity via a focus on Aino Kallas' management of her life and the reflections of her life experience in her life writing. In various ways, articles in this section evoke the concept of the border that may imply a demarcation line between two cultures - Finnish and Estonian. It concentrates on the effect of cultural encounters and border crossings upon travelling, the complex and shifting nature of the borders of "fictional" texts and autobiographical accounts, and addresses the framing processes of the authorial image constructed through visual means during Kallas' lifetime. Basing her argument on Juri Lotman's claim about the creative potential of 
the periphery, Sirje Olesk analyses the position of Aino Kallas on the borderlines of two national literatures as an interesting example of the enriching and inspiring influence on "the other" to a writer's work. The life and work of Aino can be looked at as a constant movement between various borders, most importantly the cultural and linguistic border between Finland and Estonia, the generational gap between the intellectuals affiliated with the newspaper "Postimees" and the literary grouping Young Estonia, and artistic quests between realism and modernism during the 1910s. Ritva Hapuli's article represents Aino Kallas as a traveller and travel writer, testifying to Kallas' identification as a world-citizen. Arguing that Kallas' interests and skills as a novelist are to be seen also in her travel narratives - a doubly marginalized type of narrative because of the marginal relevance of the genre and due to the fact that travelling and travel narratives have been dominated by men - Hapuli offers an analysis of Kallas' Marokon lumoissa [Under the Spell of Morocco] (1931) as a Finnish representative of the controversial women's Orientalism.

Maarit Leskelä-Kärki's contribution focuses on the autobiographical connections in the texts of ageing Aino Kallas, investigating the letters, diaries and poems that Aino Kallas wrote during the 1940s. Leskelä-Kärki analyses the ways in which Kallas used poetry as a place to remember, mourn and cope with the losses in her life in the 1940s, drawn from Kallas' last remaining diary documents, entitled after her death Vaeltava vieraskirja [The Wandering Quest Book] (1957) and forming a touching document of an ageing woman writer that solidifies the connection between writing and mourning. In Leskelä-Kärki’s view, ageing Aino Kallas and her late production offers a different perspective of the canonised picture of Kallas as a writer and her connections to modernity. Tutta Palin and Kai Stahl outline the Aino Kallas iconography, suggesting new attributions and complements to her image by presenting some less known material, especially from Estonian archives, including some line drawings that present Kallas from a fresh angle. Yet they also correspond with the two main iconographic variants, that of the mystical dark woman in 'Art Nouveau' or Symbolist terms, and that of the more somberly elegant 'New Woman' of the inter- and postwar era. Elaborating on the interactive processes through which her portraits were produced and selected for publicity, Stahl and Palin show that visual self-presentation, articulated in carefully weighed experimentations with both 'traditional' and 'modern' female types and feminine styles, was an integral part of Kallas' authorial strategies.

Work on this collection was supported by an Estonian Science Foundation grant "Positioning Life-Writing on Estonian Literary Landscapes", Cultural Endowment of Estonia, and the Vihuri Foundation. We would like to thank Marlene Broemer and Blake Royer for language editing, Tiina Kirss and Marika Liivamägi for translating some articles from Estonian into English, and Paavo Castrén and Kalle Pihlainen for translations of Aino Kallas' work into English. We would also like to thank Rutt Hinrikus, Leena Kirstinä, Maarit Leskelä-Kärki, Kukku Melkas, and Sirje Olesk for support and assistance during various stages of work on the collection, and Tutta Palin and Kai Stahl for expert advice on the cover image of the collection. 
We would also like to thank the Finnish Literature Society for accepting the volume for their Studia Fennica Litteraria Series, the publishing directors Päivi Vallisaari and Tero Norkola, and editorial manager Johanna Ilmakunnas for their support and work with the collection.

\section{Notes}

1. [Mina kuulun maailmalle.]

\section{References}

\section{Research objects}

Kallas, Aino 1920: Katinka Rabe. Helsinki: Otava.

Kallas, Aino 1956: Päiväkirja vuosilta 1927-1931. [Diary from the Years 1927-1931.] Helsinki: Otava.

\section{Research literature}

Ardis, Ann 2003: Introduction. In: Ann L. Ardis \& Leslie W. Lewis (eds.), Women's Experience of Modernity, 1875-1945. Baltimore: Johns Hopkins University Press.

Benstock, Shari 1986: Women of the Left Bank: Paris, 1900-1940. Austin: University of Texas Press.

Dekoven, Marianne 1992: Rich and Strange: Gender, History, Modernism. Princeton: Princeton University Press.

Felski, Rita 1995: The Gender of Modernity. Cambridge, Mass.: Harvard University Press.

Gilbert Sandra M. and Susan Gubar 1987: No Man's Land. The Place of the Woman Writer in the Twentieth Century. Volume I: The War of the Words. New Haven and London: Yale University Press.

Gilbert, Sandra M. and Susan Gubar 1989: No Man's Land. The Place of the Woman Writer in the Twentieth Century. Volume II: Sexchanges. New Haven and London: Yale University Press.

Hanson, Claire 1998: Looking within: Women's writing in the modernist period, 1910-40. In: Marion Shaw (ed.), An Introduction to Women's Writing From the Middle Ages to the Present Day. Hemel Hempstead: Prentice Hall.

Hanscombe, Gillian and Virginia L. Smyers 1987: Writing for Their Lives: The Modernist Women, 1910-1940. London: The Women's Press.

Hill, Maryli 1999: Mothering Modernity: Feminism, Modernism, and the Maternal Muse. New York: Routledge.

Kurvet-Käosaar, Leena 2006: Embodied Subjectivity in the Diaries of Virginia Woolf, Aino Kallas and Anaïs Nin. Tartu: Tartu Univeristy Press.

Lappalainen, Päivi 1995: Tuoksuvat kukat ja kultaiset hedelmät. Aino

Kallaksen Katinka Rabe identiteetin rakentumisen kuvauksena. [Fragrant Flowers 
and Golden Fruits: Aino Kallas' Katinka Rabe as a Portrayal of the Construction of Identity.] In: K. Kurikka (ed.), Identiteettiongelmia suomalaisessa kirjallisuudessa. [Identity Issues in Finnish Literature.] Turku: Turun Yliopisto, Taiteiden tutkimuksen laitos.

Leskelä-Kärki, Maarit 2006: Kirjoittaen maailmassa. Krohnin sisaret ja kirjallinen elämä. [The Krohn Sisters: Lives in Writing.] Helsinki: Finnish Literature Society.

Leskelä-Kärki, Maarit, Kukku Melkas and Ritva Hapuli (eds.) 2009: Aino Kallas. Tulkintoja elämästä ja tuotannosta. [Aino Kallas. Interpretations of her Life and Work.] Helsinki. BTJ.

Melkas, Kukku 2007: A Struggle for Knowledge: The Historical Novel and the Production of Knowledge. In: Päivi Lappalainen \& Lea Rojola (eds.), Women's Voices. Female Authors and Feminist Criticism in the Finnish Literary Tradition. Studia Fennica, Litteraria 2. Helsinki: Finnish Literature Society.

Melkas, Kukku 2006: Historia, halu ja tiedon käärme Aino Kallaksen proosatuotannossa. [History, Desire, and the Serpent of Knowledge in the Works of Aino Kallas.] Helsinki: Finnish Literature Society.

Olesk, Sirje 1999: Kansallismielisyys ja modernismi Viron runoudessa. Kaanonin historia. In: Tero Koistinen et al (eds.), Kaksi tietä nykyisyyteen. Tutkimuksia kirjallisuuden, kansallisuuden ja kansallisten liikkeiden suhteista Suomessa ja Virossa. Helsinki: Finnish Literature Society.

Podnieks. Elizabeth 2000: Daily Modernism: The Literary Diaries of Virginia Woolf, Antonia White, Elizabeth Smart, and Anaïs Nin. Montreal: McGill-Queen's University Press.

Rojola, Lea 1992: “Konsa susi olen, niin suden tekojakin teen." Uuden naisen uhkaava seksuaalisuus Aino Kallaksen Sudenmorsiamessa. In: Tapio Onnela (ed.), Vampyyrinainen ja Kenkkuiniemen sauna. Suomalainen kaksikymmenluku ja modernin mahdollisuus. Helsinki: Finnish Literature Society. 



\section{Along the Trajectories of the New Woman}





\title{
Scheherazade's Whisper
}

\author{
Contrapuntal Readings of Aino Kallas \\ and Isak Dinesen ${ }^{1}$
}

For both Aino Kallas (1878-1956) and Karen Blixen (Isak Dinesen, 1885 -1962) the social position and public voice of "writing women" and their access to authorship were crucial personal concerns as well as lively, often vexing topics of ambient debate; both were ambitious not only to write, but to be recognized as authors, envisioning and gaining international readerships. Dinesen and Kallas are an example of "parallel lives" of women writers from northern Europe in the 20th century: their trajectories across geographic, linguistic, and cultural boundaries issue invitations to contrapuntal biographical readings, with due respect for the warnings by feminist biographers that such analyses should be grounded in the author's work, and not a reduction of the writings to ciphers of the authors "lives". 2 The personae and agency of women characters and the imagined politics of gender cut across both Kallas' and Dinesen's fictional and autobiographical writings.

Dinesen and Kallas both embody the intellectual thirst of "new women" of their era for wider horizons and space for self-expression, with the attendant resistance to social convention. They both made life choices, which positioned them through marriage at some remove from their "native" cultures, with generative results. These distances proved creatively enabling, spacious, and evocative; each writer would struggle to maintain or recreate that distance with variable success in later life. Karen Dinesen's marriage in 1913 to her Swedish cousin Bror Blixen meant seventeen adventuresome years in East Africa, with both space and stimulus for writing, until this idyllic vision was undermined by illness, the deterioration of her marriage, and the financial failure of the couple's coffee plantation. ${ }^{3}$ Aino Krohn's marriage to Estonian scholar Oskar Kallas in 1900 took her to the "near abroad" of turn of the century Tartu, where she chafed against the stuffy provincial atmosphere while finding a more hospitable micro-environment and like-minded aesthetic among the writers of the Young Estonia movement. (Laitinen 1997, 52). The summer holidays Aino Kallas spent on the Estonian islands of Saaremaa and Hiiumaa opened up the realm of local and regional history, and the striking contrasts between the legacy of slavery ${ }^{4}$ in the Estonian past 
and the past of her native Finland proved remarkably stimulating subject matter for much of her later fiction.

Both writers actively sought a wider readership than their own nation; at different points in their lives, they each found their way to English-language readerships, and to appreciative, even enthusiastic reception in English and/or American literary circles. Aino Kallas was able to cultivate her contacts in the British publishing world while her husband was Estonian ambassador in London (1922-1934), and placed a collection of eighteen of her stories, The White Ship, translated from the Finnish by Alex Matson, with Jonathan Cape publishers in 1924, with a commendatory foreword by John Galsworthy (Laitinen 1997, 283-284). ${ }^{5}$ Isak Dinesen's first collection of stories, Seven Gothic Tales, was published in the United States in 1934; both the title and her elusive pen name created intrigue that enhanced the book's reception. Both writers went on to publish subsequent story collections in English. For Kallas, these were translations of Eros the Slayer (1927), also published in the United States, and the Wolf's Bride (translated by Alex Matson and Bryan Rhys, 1930); for Dinesen, it was Winter's Tales (1942), Anecdotes of Destiny (1958), and Last Tales (1957). ${ }^{6}$

The deeper, creative relations of both writers with their languages of composition are also intriguingly multiple and fluid. Susan Hardy Aiken has pointed out the divergence of the texts of Dinesen's English and Danish tales; the stories first published in English had to be rewritten to accommodate a Danish audience. ${ }^{7}$ This "reverse accommodation" to the literary culture of her place of origin is a curious dynamic, commented upon by Dinesen's biographer Judith Thurman (Thurman 1982, 288), as well as in later Danish criticism of her work (Johannesen 1961, 32). Dinesen's working notes to her later stories were composed in a mixture of languages (Klünder 2000). Aino Kallas, fully fluent in Estonian, the close relative of her native Finnish, wrote all of her major literary and critical works in Finnish, having the advantage of an exquisitely sensitive "personal translator" in the Young Estonia writer Friedebert Tuglas. Kallas reciprocated by translating Tuglas into Finnish. This "direct broadcast" of Kallas' works to a double audience also refracts her literary persona through a doubled process of reception. Kallas' access to her source material, particularly for the Estonian stories, was in the Estonian language, as in the eye-opening conversations with her husband's uncle Carl Allas, the vicar of Karja parish, in summer 1903, and the subsequent raising of her consciousness through her own social experience of status differences in Tartu philanthropic work, as in her comments on the Red Cross Women's Committee in her diary (Laitinen 1997, 46). The multilingualism of the European educated person of her times was thus given a sharper accent by this bilingual dynamic between Estonian and Finnish.

This paper seeks to examine, in sequence and in tandem, some of the consequences of exoticizing and archaizing manoeuvres and conventions in Aino Kallas' and Isak Dinesen's short fiction. I have chosen to focus the inquiry on the first English-language collections of each writer's work: The White Ship (1924) and Seven Gothic Tales (1934), with some additional examples drawn from Dinesen's Winter's Tales (1942) and Kallas' Eros the Slayer (1927). The reasons and justifications for positioning the parallel inquiry 
are more complex than "levelling the field" linguistically or circumscribing the range of works selected for consideration from two ample oeuvres. They include both the terms under which each writer issued an intentional invitation of a new readership and metatextual issues posed by collections of short stories taken as a single whole volume. For Dinesen, this latter issue is a matter of defining a generic profile for her first book in English; for Kallas, taking a cross-section of her work previously published in other languages and resituating it under a new roof with a "title story" indicates the operation of a metanarrative by means of which Kallas greets English readers not only as a Finnish writer, but as a literary ambassador and a spokeswoman for Estonia.

\title{
Archaization and its landscape
}

The first stage of exoticization in Dinesen's and Kallas' stories is a gesture of archaization found at the beginning of the stories, laying the frame of a semi-distant "stylized" past. In some stories the frame contains a concrete date, as if to authenticate and anchor the anecdote in a specific era, or, alternatively, to evoke the "aura" of a particular time. Several of Dinesen's tales in the collections Seven Gothic Tales and Winter's Tales ${ }^{8}$ gesture toward a time eighty to one hundred years before the time of writing, as if to provide time as a fourth dimension of space: "Three quarters of a century ago there lay in Antwerp, near the harbour, a small hotel named the Queen's Hotel. It was a neat, respectable place, where sea captains stayed with their wives" ("The Young Man with the Carnation", WT 3) This degree of removal in time guarantees that the tale to be unfolded (which the narrator gives the reader, to imply it is of oral provenance) has passed through several cycles of remembering, with its festoonings and condensations as acknowledged in the opening frame:

\begin{abstract}
About eighty years ago a young officer in the guards, the youngest son of an old country family, married, in Copenhagen, the daughter of a rich wool merchant whose father had been a peddler and had come to town from Jutland. In those days such a marriage was an unusual thing. There was much talk of it, and a song was made about it, and sung in the streets" ("The Pearls", WT 104).
\end{abstract}

In addition to tales that begin with a marriage or a journey, there are those that evoke the misfortunes of a particular family with broad brushstrokes covering longer tracts of lived time, as in "The Dreaming Child".

By contrast, Dinesen's tale “The Invincible Slave-Owners” begins with a more specific oral quotation: “' 'Ce pauvre Jean', said a Russian General with a dyed beard on a summer evening of 1875 in the drawing room of a hotel in Baden-Baden" (WT, 125). With the repetition of the phrase "Ce pauvre Jean", the story is launched and set in motion. Indeed, the interjection of the formula of historical dating in the first sentence is clearly the interruption of the voice of the true storyteller by the "framing narrator", a small delay raising the narrative tension by a notch. Similarly, in "The Heroine", the 
historical date serves to situate the storyteller in the frame of the tale that is his medium:

There was young Englishman, named Frederick Lamond, who was the descendant of a long line of clergymen and scholars, and himself a student of religious philosophy, and who when he was twenty years old, attracted his teacher's attention by his talent and tenacity. In the year of 1870 he got a travelling legacy, and went away to Germany. (WT, 70.)

This thumbnail portrait of the main character contains the energy and the narrative kernel of the "anecdote of destiny" that is about to unfold.

Kallas sets up her tale "Gerdruta Carponai" in a similar manner, in the neutral voice of a historically knowledgeable narrator:

In the spring of 1710, during the Great Northern War, while the Russians were besieging Riga, a deadly pestilence called the Black Death came down from the interior to the islands, first to Hiiumaa, then to Saaremaa, thence across the little Sound to Muhu and finally during the autumn to the lonely island of Ruhnu (WS, 36).

Historical events thus concretized become the context for the happening of "marvelous and terrible things" (WS 37); what matters for the story "Gerdruta Carponai" is a new myth of origins, the post-catastrophe rebirth of the human race through the union of the highborn Gerdruta and the peasant Laes, who find each other on the beach of the depopulated island. Granted, the tale takes place within a frame of historical plausibility, in one of those periods when the Black Plague ravaged the Estonian countryside, but the dating of the tale does not alter its mythic structure or resonance. Neither, however, is the frame entirely detachable.

Slightly less oblique framing sentences locate some of Kallas' stories in a more generally periodized framework of colonial history, the trope of "seven hundred years of slavery", of which the Preface to The White Ship partakes virtually without nuance. Kallas' story “The Wedding” (in Finnish "Häät”) opens with a more ambiguous formula: "A hundred years ago a wedding was being celebrated in Saaremaa" (WS 69). "One hundred years ago" places the events in the period of serfdom, and the implicit outrage of the narrator comes from the fact that this is the recent past, not a time recessed by centuries: the first-night's privilege is a custom still in use. In yet a third manner, some stories ("Ingel", "Kupja-Pärdi surm" [The Death-Bed of Kubja-Pärt], and "The Trip to Town" [Kaupunkimatka]) leave references to the times of slavery on an implicit level, or situate the story temporally through occasional signals in the body of the story to historical realia or personages, such as the allusion to Catherine II in "The Parish Clerk and the Vicar" [Lukkari ja kirkkoherra], which also retains Vicar von Rosen's historical name. Such stories are emblematic, typological set pieces, which, like the Dinesen stories mentioned above, have the feel of folklorized anecdotes, pebbles polished to smoothness by repeated retellings; similar stories could have and probably did happen to others over long spans of time. 
In those of Kallas' stories that turn around epidemic diseases such as leprosy, the historical period in which the action transpires must be deduced from the atmosphere, as in "Young Odele and the Leper" [Legenda nuoresta Odelesta ja pitaalisesta] set in the early days of medieval colonization with its main character, the wife of Jürgen Schutte, historically particularized, and the more abstract leper's tale "The Sacrifice" [Yksi kaikkien edestä], set in an island fishing village, but with no historical place or time markers. In the larger framework of The White Ship as a collection, these two stories evoke and resonate with one another through their common subject and their contrasting social milieu and setting in time. The collection as a whole moves temporally from the more distant past of the early medieval Christianization of Estonia, "Young Odele", through the 1905 revolution with "Bernhard Riives", with a small recursion in the final (title) story, "The White Ship" [Lasnamäen valkea laiva] to the Maltsvetite movement of the 1860s.

As distinct from the fragrant rose garden and bees of "Young Odele and the Leper", "Bernhard Riives" is told with a minimalist efficiency and matter-of-factness, complete with a specific identifying tag of historical date. The "reality effect" of the text is bound up with its political moral. "Bernhard Riives" is an anecdote of destiny pivoting around a peasant who participated in the uprisings of the 1905 revolution who would rather die than be humiliated by submitting to a beating. This can be seen from the closing frame of the story, pronounced by the witness, teller, and "owner" of the tale, the young officer in the punitive squad: "But my opinion is this: in this peasant, this Bernhard Riives, seven centuries of slavery straightened its back" ${ }^{9}$ ( WS, 206).

In this context it seems appropriate to remind the reader that not all of Kallas' stories selected for the White Ship bear relentless scars of suffering under slavery. There are trickster tales, like the "Smuggler", or double trickster tales in which social unequals try their mettle and cleverness against one another ("The Parish Clerk and the Vicar", "A Trip to Town"), and stories with a likely tragic outcome infused with an alternative, even one of fantasy (Ingel's symbolic revenge for the mistreatment of her infant child by exchange of the noble child's and the urchin's garments) or belligerent hope ("The Wedding"). The belief that "mixing blood" produces strong and unusual children animates several of the stories in which boundaries between noble and peasant are transgressed, albeit in extreme conditions, as in "Gerdruta Carponai".

In Kallas' fictions, exoticization also works through sensuous prose with a lucidity so keen as to generate an effect of the "uncanny", most visible in stories with a love plot containing highly charged passages of landscape description or short notations which resonate with the passional register of the characters' interaction. In the story "Saaremaa" with which Kallas chooses to open her first English-language collection, The White Ship, landscape description also serves another purpose, that of constructing an Estonian regional landscape in a manner congruent with the collection's metatext, introducing, mediating, or "inventing" the Estonian past for an English reader at the beginning of the 1920s: 
The whole is crushed and meek, as though trampled for ages under an iron heel. For those with eyes to see-the starved, accusing features of a labour-slave stare from all quarters of the sun-baked, unworked pasturage. Even the Saaremaa rock mirrors a slavish soul, never rising to the height of a mountain, never defying the heavens, but withdrawing into the earth, hiding its menace in its heart, like a slave. (WS, 19-20). ${ }^{10}$

In contrast to the delicate use of environmental detail, such as Kallas' frequent and favourite trope of bees to accent passionate moments, this kind of landscape drawing is rather heavy-handed, sometimes due to the ideological freight: "Much history exists of Saaremaa, but Saaremaa itself is its own most impartial historian. The record of seven centuries of slavery is written upon its landscape"11 (WS, 19). As the Saaremaa landscape becomes for Kallas a synecdoche for the territory of Estonia as a whole, a concentrated model across which the narrative of colonial violence is deployed and instantiated, regional variations recede from view. The story of Estonia's past is writ large in Saaremaa and "anecdotes of [its] destiny", and the reader does well to keep a steady gaze against the wobbling boundary between fiction and history.

Alternatively, the inscription of harsh history on the landscape is "read" or translated by an "alien" narrator, walking in the countryside, or taking a bird's eye view of the island from the privileged position of a genial traveller, furnished with asides and comparisons from different places, including the manor gardens, to whom he or she is no stranger. In at least one example, such comparisons of agrarian reality with manor and church have a bizarre, almost mannerist effect. The sheep of Saaremaa cause a cultured panorama to emerge from a barren wilderness:

Gnawing from all sides at the bushes they reduce them to large green hummocks, set side by side on the level ground. They stand as it were in a rococo garden, clipped into decorative form by the hand of a skilful gardener, some round as spheres, others elongated like eggs, others shaped to resemble onions, or the cupolas of Russian churches. (WS 17-18). ${ }^{12}$

This panoramic pastoral view is sustained in a horizontal sweep, moving inland from the beach, and culminates in the village and its dwellings.

The landscape improves progressively - the cattle plains give way to moors covered with hazel-bushes, where swollen with pride the juniper achieves the status of a tree, and looks like a poor stunted copy of the cypresses in the graveyard groves of the south"13 (WS 18).

In keeping with common knowledge of regional folklore, the juniper as a symbolic element signifies both endurance and stuntedness of growth, echoed on another level by the huts of the hamlet, huddled together and close to the ground. This evocation of the human settlement yields via the figure of the windmill on its stone foundation, to what the narrator deems to be the "heart" of Saaremaa: 
The heart of Saaremaa is of stone. When the land cracks during the spring floods and rains, it lays bare whitey-green limestone, the bone beneath the deep open wounds of the earth. Of such is the backbone of Saaremaa. (WS 19.) ${ }^{14}$

It is intriguing to compare this construction of a landscape with the opening of Dinesen's "Sorrow-Acre", in which the setting for the story is first parsed horizontally, then refracted through the prism of reading and read vertically:

A child of the country would read this open landscape like a book. The irregular mosaic of meadows and cornlands was a picture, in timid green and yellows, of the people's struggle for its daily bread; the centuries had taught it to plough and sow in this way. On a distant hill the immovable wings of a windmill, in a small blue cross against the sky, delineated a later stage in the career of bread. The blurred outline of thatched roofs - a low, brown growth of the earth - where the huts of the village thronged together, told the history, from his cradle to the grave, of the peasant, the creature nearest to the soil and dependent on it, prospering in a fertile year and dying in years of drought and pests" $(W T, 30)$.

The reader, the "child of the country" also deciphers the place of the redtiled church, also referred to as "a strange house, inhabited only for a few hours every seventh day", and the country house at the centre of the estate: "The child of the land would read much within these elegant, geometrical ciphers on the hazy blue. They spoke of power, the lime trees paraded round a stronghold" (WT, 30).

If a parallel reading of "Sorrow-Acre" and "Saaremaa" renders visible different aspects of the symbolic economy of Dinesen's and Kallas' stories, and accents the greater importance for Kallas of a metanarrative of colonization and slavery taken over from "real history", the two writers meet on the level of the kinds of narrative situations they craft in "The White Ship" and the more heterogeneous stories of "Winter's Tales". They also intersect in their studies of gender relations, and in their evocation of the powers specific to women, even when female characters are accused and punished as women for breaking social taboos.

\section{Is the storyteller a woman?}

Aino Kallas foregrounds the magical and ritual aspects of women's power in several of her stories, and in this sense shares Dinesen's hopeful awe toward women's "witchcraft". Though she has no comparable "mistress-trope" for the female storyteller comparable to Dinesen's Scheherazade, and though she adopts no pseudonymous mask as Karen Blixen does, the cross-dressings of (oppressive) voice in the male narrators of several of Kallas' stories, and her novel Reigin pappi [The Rector of Reigi] raise different questions about camouflage, gender-crossing, and subterfuge, as does the character Aalo, who shapeshifts into wolves to gain voice. A useful contrast in this respect is provided by the short novel "The Wolf's Bride" and the story "The 
White Ship", both stories of women voicing desire bring the characters to ruin: the Wolf's Bride through heresy, the Maltsvetian Maie Merits renouncing her visionary longing for the "white ship" and her charismatic leadership to return home to woman's sphere: "She remembered her husband, her sons, her everyday tasks, the chamber behind the shop and the bread baking in the oven, and her hands went instinctively to her unplaited hair, while her heart turned sick with longing"15 (WS 256).

Cross-dressing the narrator as a male storyteller may be considered an integral part of the overall exoticization that takes place in Kallas' Estonian stories, and it is an interesting question whether it occurs as an effect of point-of-view or "voice", or a combination of both. ${ }^{16}$ In some of the stories included in The White Ship collection, the reins of the narrative seem to be summarily "handed" to a male narrator. For example, in "Bernhard Riives" the story is told by a young officer from the punitive expeditions to the Baltics following the revolutionary events of 1905, who is thereby treated the source and proprietor of the tale, and whose voice is "impersonated"; in "Bernhard Riives" there are no (speaking) women characters at all, and the denouement consists of a dialogue between the officer and Riives himself, revealing Riives' moral stringency and unbending nature. The tale's concluding moral is prophetic of the implications and consequences of the "slave's unbroken back". Power dynamics between peasant and manor servant sometimes play out through a combination of dialogue and style indirect libre, as in the deftly wrought plot twists of "The Trip to Town" and "The Parish Clerk and the Vicar", arranged next to each other in the collection as companion pieces.

Kallas' fictions contain many parabolic patterns of gender relations impacted by colonial relations, with sujets drawn from Estonian folklore and cultural history. Reading the stories within the framework of their arrangement in the collection, two women of very different social standing - Young Odele and the peasant wetnurse Ingel - sit with infants on their knee. Infertility is at the root of the bitterness of Kubja-Pärt's marriage; fertility and childbearing are a woman's birthright, a source of joy and fulfillment, as in "Alien Blood" [Vieras veri] and "Ingel", even if the church condemns unwed motherhood, and despite the yoke of slavery. If Dinesen's intarsia stories contain various comic elements, and often resolve even hopeless situations in the spirit of high comedy, Kallas' stories typically come to more tragic conclusions - whether due to unrequited or forbidden love, or inflected by practices of gendered colonial violence, such as the forced abandonment of her own infant by a peasant mother summoned as wet-nurse for the baron's son ("Ingel"); the baron's "first night's privilege" ("The Wedding"); or, as in "Bathsheba of Saaremaa", a husband's conscription into the Tsar's army through the baron's sealed letter, evidence of a wife's betrayal, intuitively voiced by the suspicious mother-in-law Old-Kai. In this complex story in the form of a play, the sexual politics of peasant woman and baron is narratively tooled on the anvil of the Biblical tale of David and Bathsheba.

Perhaps the only Dinesen tale that in its tonality approaches the tragedy of Kallas' Estonian tales is the often-anthologized "Sorrow-acre", in which an 
old peasant mother buys her falsely-accused son's freedom from the landlord by a superhuman and mortal feat; ploughing a rye field alone in one day, the mother dies in her son's arms at sunset. In part the tragic outcome is entailed by the historical topoi Kallas chooses as thematic terrain: the passion of Barbara von Tisenhusen for a low-born schoolteacher, and her drowning by her brothers is a tale of both gender and colonialism; the tragic heroine is a victim of the code of honour that accompanied and sustained German colonial rule in the Baltic lands. This dictate of the subject matter is amplified in The White Ship by a metatext, established by both Kallas' own preface and by the opening story, "Saaremaa". A further important nuance in the Estonian tales is Aino Kallas' fascination with contemporary theories about race and "breed"; the mystique of racial difference and "alien blood" seems located at an even deeper substratum of her fictional texts than the probing of the psychic energy vectors of gendered passion. The racial topos subtends Kallas' colonial narrative of Estonia's past, and alien-bloodedness adds additional charge to several of the stories, particularly those with major characters from "intermediate" social categories, such as parish-clerks and bailiffs. ${ }^{17}$

\section{The Gothic and parables of gender}

In Dinesen's stories, particularly in her "Gothic tales", the narrative dynamics are generated from gendered "social" relations in an insistently fictionalized world in which "normal" social relations have ceased or been suspended. These fictions are played out through artful patterns of embedded stories, qualifying each other by means of their frames and tellers. The stories are illustrations of the limits of "gender rules", the consequences of transgressing them (at times liberating), and the loopholes of alternatives visible from odd angles of perception. In keeping with reading Dinesen and Kallas "contrapuntally", I shall examine some of the lines of their divergence, through an examination of the narrative logic of a few of Dinesen's Gothic tales. ${ }^{18}$

"The Roads Round Pisa" gravitates around two young women, Rosina and Agnese, who are friends, "blood sisters", and allies, who never appear together in the same frame, except as part of the grandmother's narrative. While in "The Supper at Elsinore", Fanny and Eliza both fit their brother's estimation of women who have no price, and who "ought not to have been women", Agnese, who is younger than Rosina, actively carries out her own fantasy of female freedom and adventure, including cross-dressing as a man: "This girl had been allowed to grow up wild and had become a real child of her age. She got into her head the wild notion that she looked like the Milord Byron ... and she used to dress and ride as a man, and to write poetry" (GT, 174). Agnese is single while Rosina is trapped in a marriage to the impotent Prince Pozentiani, an alliance arranged for her by her step-grandmother to prevent her sharing her mother's fate of death in childbirth. Agnese uses her greater freedom to act as her friend's courier and go-between, and substitutes for Rosina in bed during Rosina's 
clandestine visit to her lover. The surprise appearance that night of Prince Pozentiani's substitute, Prince Nino, by whose agency he is to conceive his heir, binds Agnese to an even more complex destiny than the intrigue of her friend. Agnese's success depends upon her cross-dressing, her imitation of the male role, even to the point of serving as a second in a duel, and upon her adeptness at telling stories. In the sixth section of the tale, where the marionette show is revealed as both a replica and pivot of the interlaced narratives, Agnese "followed the development of the plot in the spirit of a fellow author" $(G T, 13)$. A few pages later, still disguised as "Daniele de la Gherardesci", she consents to play the part of Prince Nino's second in the marionette comedy of the duel, and tells Prince Nino the story of Joseph and Potiphar's wife from the perspective of Potiphar's wife as an old woman. The story both maintains and reveals her disguise: she, not Rosina, is the woman Nino slept with, and the duel will release both Agnese and Nino from the symbolic stasis of the moment when they recognized their mutual love and consummated it without confessing it.

Cross-dressing is an important issue in "The Roads Round Pisa", and it is a curious feature of the third important woman in the story, Carlotta, Rosina's step-grandmother, that she appears initially as a man. Carlotta is the first to release the narrative momentum of the tale when she appears on the scene as the victim of a carriage accident. At first glance she appears as "a bald old man with a refined face and a large nose", but, replacing her bonnet, inside which was fastened "an abundance of silvery curls", she becomes "a fine old lady of imposing appearance" $(G T, 169)$. Late in the story, after the birth of her great-grandson, she again appears in the male role in a tiny inset tale of the Nativity. For Dinesen, these miniatures, whether they are theatrical scenes or tableaus, or narrative cameos like Agnese's story, retell a traditional tale from a woman's point of view.

Carlotta, who is desperately plotting to prevent Rosina from bearing a child by her lover Mario, is both a storyteller and a stage manager. It is she who tells Rosina's story to the central character of the outer frame, the melancholy Augustus von Schimmelmann, and assigns him a mediating place in its denouement. Unlike the aged and faithful housekeeper Madame Baek in "Elsinore", who first receives the strange visitation of the dead son of the household and goes to bring the sisters from Copenhagen to the ghostly supper, Carlotta is unable to mediate her plot directly because of her injuries in the carriage accident. Her story, which forms the third section of "The Roads Round Pisa", is a deathbed confession, and the addressee, Augustus von Schimmelmann, is a stranger to her. The motivation of the tale is in part confessional, and in part pragmatic. She needs a nobleman to carry out her errand, and she enlists Augustus's services to see it through.

It is interesting that Carlotta, both a prohibitive and protective presence in the life of her step-granddaughter Rosina, is the one who tells Rosina's tale as well as her own. At no point does Rosina appear to tell her own story. One wonders about the narrative strategies behind this indirection, which therefore calls for a closer examination of the power dynamics between the older and younger woman in this pair. Rosina is by no means a conventional character, though she is caught up in the traditional roles of wife, lover, and 
mother. At every step of her apprenticeship to traditional roles, she has offered up her defiance along with her extraordinary beauty. Upon the announcement of her betrothal, she appears before her grandmother "as lovely as the young St Michele commanding the heavenly hosts" $(G T, 173)$ to tell her that she is in love with her cousin Mario and would marry no one else. Carlotta describes her own counteroffensive, which includes the Gothic device of shutting up the young virgin in a castle, but the reader learns nothing of Rosina's actual response to her imprisonment. The reader does, however, learn that she sabotages the marriage by publicly proclaiming the impotence of her husband Prince Pozentiani, turning him into public laughingstock, and by applying to the Pope to annul her marriage. Rosina desires the traditional benefits of marriage and family, but she is willing to use unconventional means to receive them on her own terms.

Carlotta's solution to the dilemmas of womanhood is the radical one: she is terrified of childbirth, and "trades" in her wealth and beauty for the promise of her widower husband, whose first wife died in childbirth, that he would give her no children. Carlotta's fear marks her tutelage of her stepgranddaughter (Rosina) in whom she affirms the attitudes of the goddess Diana toward men: "I did not want her to marry, so I was for a long time pleased to see the hardness and contempt that the child showed toward all men, and especially toward the brilliant young swains who surrounded her with adoration" $(G T, 172)$. Carlotta's role in orchestrating and narrating Rosina's destiny, and in organizing the whole tale around the germ of her fear, is a fascinating example of the female storyteller's power. It is perhaps most interesting that while her radical (feminist) pedagogy fails with Rosina, whose story ends happily contrary to Carlotta's designs and expectations, Carlotta succeeds in teaching Augustus, whose own search for a truth and identity occurs in the context of an unhappy marriage to a beautiful and jealous woman.

Dinesen's tales are entertainments, part of the pleasure of which derives from teaching and learning, with all the inventiveness that these require. The devices of "imitation Gothic" (or "Gothic revival"), including the conventions of violence of that genre, serve to outline the playing field in which gender dilemmas risk being taken too seriously by the characters participating in the fiction. In "Deluge at Norderney", the first story in Seven Gothic Tales, Malin Nat-og-Dag, an eccentric spinster noblewoman, tells a younger woman's tale. In the hayloft that Malin has turned into a salon, the four refugees from a sudden tidal wave tell their stories to pass the time before the rising waters claim them. The Countess Calypso von Platen Hallermund is Malin's sixteen-year-old goddaughter, who has fled from the castle of her homosexual uncle, a kind of male counterpart to the convent in "The Monkey", where - true to Gothic convention - Countess Calypso has been imprisoned. Malin herself tells the story of Calypso's escape: convinced that her femaleness would cut her off from the only companionship possible within her uncle's "fiefdom", was prepared to cut off her breasts with a hatchet. As she prepares for this ritual self-mutilation in her great-grandmother's attic, she notices a painting of nymphs on the wall, and recognizes a beauty companion to her own. After this sexual awakening, she proceeded to her 
uncle's bedroom, but finds it unnecessary to kill him with the hatchet, for he is not half as threatening, as he once had seemed. Instead, accompanied by Malin, she escapes to the seaside resort of Norderney, where the destinies of the hayloft refugees converge.

It is interesting that though Calypso has broken free from a classically Gothic situation of imprisonment, she remains silent throughout the "Deluge at Norderney". She is the only one of the characters who does not tell a story, and she submits unquestioningly, though perhaps with a twinkle in her eye, to the mock wedding that Malin and the False Cardinal celebrate between herself and the melancholy young "hero" Jonathan Maersk. The relationship between Malin and Calypso echoes that of Carlotta and Rosina in "The Roads Round Pisa", one of many examples of such interlacings between the separate Gothic tales.

The important difference accentuating the powers of the female storyteller is the explicit evocation of Scheherazade at the end of the tale. As dawn breaks with the floodwaters reaching the floorboards, Malin interrupts a story she has just begun telling to the Cardinal about her childhood freedoms with the words, "à ce moment de sa narration ... Scheherazade vit paraître le matin, et, discrète, se tut"19 $(G T, 79)$. Indeed, Malin has aligned herself with Scheherazade's narrative situation earlier in the tale. Calypso is the narratee of her tale, just as Scheherazade told tales to the Caliph with her sister as the silent narratee. The are abundant implications for the narrative dynamics of "Deluge" and for the collection Seven Gothic Tales as a whole, of the figure of Scheherazade - disguised as an elderly spinster.

\section{Conclusion: Scheherazade's whisper}

In the 1980s, Dinesen's story “The Blank Page” became an allegory of feminine creativity for Anglo-American feminist literary critics seeking to define a feminist poetics, literary foremothers, and a "female tradition". The search - even the hunger - for such allegories, epitomized by the adoption of the "Blank Page", was symptomatic of a perceived lack of compelling models of female creativity, and complemented empirical and documentary efforts to rescue women writers from miniaturization and from other reductionist manoeuvres in literary history. ${ }^{20}$ In the case of Dinesen, the choice of "The Blank Page" eclipsed the far more extensive material of gender allegories and parables in her works, including those with more complex skeins of intergenerational relationships, tropings on androgyny and cross-dressing. It is far more suggestive to examine Dinesen's stories in the wider perspective of generic subversion, what Susan Hardy Aiken calls "a countertextual thematics of female authority and creativity" (Aiken 1984, 172). More recent scholarship, including Aiken's own, has corrected this selectivity, focusing on Dinesen's use of tropes of masks and witchcraft in the staging of women's power, along with meticulous textual studies of her evocation of the figure of Scheherazade as the emblem for the female storyteller.

While Scheherazade illustrates the complexity of the self-positioning of a woman writer from Scandinavia who is unwilling to remain within 
the boundaries of nice, proper "women's literature", there may be more disturbing implications to the "orientalist" symbolism of the narrator of the Arabian Nights. What does it mean in a larger sense to gesture as Dinesen does toward Scheherazade, to "borrow" her, to assume her mask? Seen with a postcolonial eye, this gesture may cohere with the implicit presuppositions of Dinesen's romanticization of Africa and its oral traditions in Out of Africa. One should not be trapped, however, by the impulse to postcolonial correctives. On the one hand, as Abdul JanMohamed has pointed out, Dinesen's cultural knowledge of East Africa through a prolonged period of living there, and her eschewing of conventional colonialist attitudes and pronouncements is a commendable fact (JanMohamed 1983, 57). In the cultural text of the Arabian Nights, widely disseminated in the west, the position of Scheherazade as a narrator circulates tacitly, though it has received far less direct attention than the exotic fabric of her tales. Dinesen calls attention to this frame, suggesting that women's compulsion to tell a story may indeed be a survival tactic, a metaphorical way to defer rape, mutilation, and death - as such a manifestation of storytelling as witchcraft. As readers with "postcolonial eyes", one should be careful to notice both the blindnesses and the insights of this undertaking.

To theorize about the female storyteller is to extend Walter Benjamin's ideas concerning the cultural function of the storyteller. The woman artist haunts Benjamin's essay, whether as the maternal righteous man of Leskov's tales, the silkworker in the quotation from Valéry, the Muse of epic remembrance, or the resourceful Scheherazade, who begins fresh stories under the Muse's tutelage (Benjamin 1977). ${ }^{21}$ There is a further paradox regarding the masking and framing of Dinesen's tales. If Scheherazade's storytelling is staged as an internal frame to Dinesen's stories, she plays with more conventional ways of women writer's masking who they are and what they are doing under cover. Dinesen's use of a male pen name is a time-honored key for women accessing public authorship "legitimately", as well as a crowning joke on this device. "Isak", which means "laughter" in the Biblical story of Abraham, delightfully deceived the American readers of Dinesen's Seven Gothic Tales, at least at first.

Dialectical and uneasy relations with "modernisms" in the literary cultures of their primary audiences is yet another level at which Kallas and Dinesen can instructively be set alongside each other, and this would require a much longer and separate examination. Dinesen in her "stylized Gothic" stories, and Kallas in her historical fictions of Estonia, take stances on an exoticized, "occulted" past: while this gesture and the conventions adopted to implement it may arguably be "of modern spirit", or based on pastiche, as in the "Gothic revival" one should hesitate before the attribution of the label of "modernism" to either of these two writers. ${ }^{22}$ It could equally plausibly be claimed that both Dinesen and Kallas resist "writing modern" in their own particular ways. Dinesen's stories deploy a Boccacian strategy of embedded narratives and inset tales, thus creating interpretive possibilities in which each frame relativizes the other. This level of artifice - which often reaches a high level of "mannerism" is avoided, if not foreclosed, by Kallas, except in the rare instances in which she writes in the mode of a 
stage play, as in "The Bathsheba of Saaremaa" or at the end of "Bernhard Riives" where the frame is not closed by the narrator of the first line of the story, who passed on the talking stick to the young officer. For Kallas and Dinesen, exoticization and the deliberate use of archaization are more than emblematory artifice, and more than thematic features; rather they are part of a posture that makes writing possible at all - even for the imaginary granddaughters of Maie Merits, and the sisters of Scheherazade.

\section{Notes}

1. The article has been written with the support of ESF grants 7354 ("Positioning Life-Writing on Estonian Literary Landscapes") and 7271 ("Writing Women': Women in Estonian literary and cultural history 1880-1925").

2. Cf. Phyllis Rose, Parallel Lives: Five Victorian Marriages (London: Knopf, 1984). Examples of comparative and contrapuntal biographies of women writers indicative of directions in which Kallas and Dinesen would fruitfully be examined include Susan Horton's Difficult Women, Artful Lives: Olive Schreiner and Isak Dinesen (Baltimore: The Johns Hopkins University Press, 1995) and Ellen Moers' collective biography Literary Women (Oxford, Oxford University Press, 1977). Specific to the literary life of Aino Kallas, two in-depth studies should be mentioned in the current context: Maarit Leskelä-Kärki's doctoral dissertation on the Krohn sisters, Kirjoittaen maailmassa. Krohnin sisaret ja kirjallinen elämä, [The Krohn Sisters: Lives in Writing] (2006) and Leena Kurvet-Käosaar's dissertation on women's diaries, Embodied Subjectivity in the Diaries of Aino Kallas, Virginia Woolf and Anaïs Nin, (2006). Both of these studies provide suggestive models for contrapuntal readings based on lifewriting and epistolary writing as sources.

3. As Susan Hardy Aiken indicates based on Karen Blixen's letters, "For all its unconventionality by bourgeois standards, the couple's decision to immigrate to British East Africa in 1913 was ... the re-enactment of a well-worn convention: the European topos of Africa's terra incognita as a fertile, alluring El Dorado" (1990, 37). Karen Blixen was infected with syphilis within her first year in East Africa; her marriage failed by the end of WWI, and she was forced to leave the farm and Africa in 1930 (Thurman 1982, 282).

4. Slavery, used by Aino Kallas as a general signifier, needs historicizing in the Estonian context. One step toward specificity can be taken using two terms in common use-pärisorjus (in literal translation "true slavery"), referring to the period from colonization and christianization of the eastern Baltic in the 13th century when Estonian peasants were tied to the land as the serfs of German barons, up to the czar's decree that the Estonian peasants be set free, in 1816 and 1819 respectively, and teoorjus (corvee labour), the period after 1816 and through the closing decades of the 19th century, when more and more peasants began purchasing their land from the baronial estates. Regional and local contextualization is also important, since the regime of the landlord could vary from benevolent patriarchy to extremes of colonial violence. It is interesting that Aino Kallas subsumes these two terms (which she surely would have known as an Estonian speaker and through her study of Estonian history) under the general designation "slavery"; by refusing the historical differentiation, she in fact achieves a darker and starker portrait of the condition of the Estonian peasantry.

5. Reference to stories in the collection as WS.

6. On the context and publication history of Kallas' works in England, see Laitinen 1997, 152. 
7. The Gothicism of Dinesen's first book to be published in English, "Seven Gothic Tales" is in Susan Hardy Aiken's view "doubly mimetic": Dinesen claimed to write in a way evoking the "Gothic revival", as it was seen in English, American, and Continental literature from the 18th century onward. "As a Dane writing to capture an English audience, she playfully assumes the role of a latter-day northern "barbarian", translating writing into a kind of raiding" (Aiken 1990, 68). This playful interpretation indicates the kind of literary posing characteristic of Dinesen as an author.

8. Reference to the stories on the collection as WT.

9. [Mutta minun mielipiteeni on: tässä talonpojassa, tässa Bernhard Riiveksessä suoristui seitsensatavuotisen orjuuden selkä.] (Kallas 1995, 19)

10. [Koko maisema on masennettu ja nöyra, aivankuin olisi pitkät ajat raskaan rauta-anturan alle tallautunut. Ne ovat työorjan nälkiintyneet, syyttävät kasvot, jotka paistavat joka puolelta vastaan kovaksi kuivuneesta, käyttämättömästä karjamaasta, - sille, jolla on silmät nähdä. Saarenmaan kivessäkin on orjan luonto, se ei milloinkaan vuorina kohoa, ei taivasta uhmaile, vaan maan sisustaan vetäytyy, kätkee uhkansa sydämeensä kuin orja.] (Kallas 1928, 9.) The translator's choice to render the Estonian word pärisori as labour-slave is an interesting one. See footnote 3 (the surpluses and the deficits of this choice are intriguing).

11. [On monta historiaa Saarenmaan menneisyydestä, mutta ei yhtäkään niin puolueetonta kuin tämä luonto. Saarenmaalla luonto kirjoittaa historiaa seitsensatavuotisesta orjuudesta.] (Kallas 1928, 9.)

12. [Ne jytystelevät katajapensaita joka puolelta, pureskellen ne suuriksi, vihreiksi mättäiksi, jotka toinen toisensa vieressä eroavat tasangosta. Se on kuin rococo-aikuinen puutarha, jonka taitavan puutarhurin käsi on kuvioiksi leikellyt, toiset ovat ympyriäisiä kuin pallo, muutamat munan soikeita, toiset supistuvat säännölliseksi sipuliksi kuin venäläisen kirkon kupu] (Kallas 1928, 8).

13. [Maisema kehittyy vähitellen, - karjamaat muuttuvat matalaa pähkinäpensaikkoa kasvavaksi nummeksi, tulee vastaan keto, jossa kataja yhtäkkia on kiivennyt puuksi, ennenkuulumattomassa ylpeyden puuskassa, muistuttaen huonoa, kituvaa jäljennöstä etelän hautasypressilehdoista] (Kallas 1928, 8).

14. [Saarenmaan sydän on kiveä, kevättulvien ja sateitten aikana lohkeilee äkkiä maa, ja tulee näkyviin valkeanvihertävä kalkkikivi, aivankuin olisi maassa luuhun asti ulottuva haava. Se on Saarenmaan selkäranka.] (Kallas 1928, 9.)

15. [Hän muisti miestään, poikiaan, arkipäiväistä askarettaan, puodintauskamaria ja uunissa paistuvia leipiä, ja hänen kätensä palmikoitsivat vaistomaisesti vanunutta tukkaa, samalla kun hänen sydämensä oli sairas ikävästä.] (Kallas 1957, 385.) See Lea Rojola's article in this volume for a theoretically and interpretively compelling reading of this story. My own reading of the tale leans toward a more pessimistic view of the ending, in line with Rachel Blau Duplessis ' claim that the endings of modern stories by women about women often shortcircuit bolder possibilities, even when "subtexts and repressed discourses can throw up one last flare of meaning” (Duplessis, 1985, 3).

16. Kukku Melkas provides an insightful analysis of this issue in the third chapter of her book, Historia, halu ja tiedon käärme: Aino Kallaksen tuotannossa [History, Desire, and the Serpent of Knowledge in the Works of Aino Kallas.], (Helsinki: Suomalaisen Kirjallisuuden Seura, 2006).

17. See articles in this volume by Kurvet-Käosaar and Hinrikus.

18. Reference to the stories on the collection as GT.

19. [At that moment in her story...Scheherazade saw that dawn had broken, and discreetly fell silent.]

20. E.g., Sandra Gilbert and Susan Gubar, The Madwoman in the Attic: the Woman Writer and the Nineteenth-Century Literary Imagination (New Haven: Yale University Press, 1979).

21. Benjamin's essay "Der Erzähler" is subtitled "Betrachtungen zum Werk Nikolai 
Lesskows." The essay seems deliberately and cleverly to avoid the matter of the gender of the storyteller. Thus the "spangling" of the essay with shadow-women as storytellers is especially intriguing, a topic heretofore unexplored in Benjamin scholarship.

22. Toby Foshay issues this caution with respect to unreflective appropriation of Isak Dinesen as a modernist writer (Foshay 1994, 193).

\section{References}

\section{Research objects}

Dinesen, Isak 1957: Last Tales. New York: Vintage.

Dinesen, Isak 1934: Seven Gothic Tales. New York: Random House.

Dinsen, Isak 1942: Winter's Tales. New York: Random House.

Kallas, Aino, 1928: Novelleja. Helsinki: Otava.

Kallas, Aino, 1927: The White Ship. Estonian Stories by Aino Kallas. Translated from the Finnish by Alex Matson. London: Jonathan Cape.

Kallas, Aino, 1957: Valitut teokset. Helsinki: Otava.

\section{Research literature}

Aiken, Susan Hardy 1990: Isak Dinsen and the Engendering of Narrative. Chicago: University of Chicago Press.

Benjamin, Walter 1977: Der Erzähler. In: Walter Benjamin, Illuminationen. Ausgewählte Schriften. Frankfurt: Suhrkamp.

Duplessis, Rachel Blau 1985: Writing Beyond the Ending. Bloomington: Indiana University Press.

Foshay, Toby 1994: Isak Dinesen's The Pearls: Resentment and the Economy of Narrative. In G. A. Woods (ed), Isak Dinesen and Narrativity. Ottawa: Carleton University Press.

JanMohamed, Abdul 1983: Manichean Aesthetics: The Politics of Literature in Colonial Africa. Amherst: University of Massachusetts Press.

Johannesson, Eric O. 1961: The World of Isak Dinesen. Seattle: University of Washington Press.

Klünder, Ute 2000: "Ich werde ein grosses Kunstwerk schaffen..." Eine Untersuchung zum literarischen Grenzgängertum der zweisprachigen Dichterin Isak Dinesen/ Karen Blixen. Göttingen: Vandenhoeck \& Ruprecht.

Kurvet-Käosaar, Leena, 2006: Embodied Subjectivity in the Diaries of Virginia Woolf, Aino Kallas, and Anaïs Nin. Dissertationes litterarum et contemplations comparativae Universitas Tartuensis. Tartu: Tartu University Press.

Laitinen, Kai 1997: Aino Kallas. Uurimus Aino Kallase loomingu peateemadest ja taustast. [Aino Kallas. A Study on the Main Topics and Background of her Work.] Tallinn: Sinisukk.

Leskelä-Kärki, Maarit 2006: Kirjoittaen maailmassa. Krohnin sisaret ja kirjallinen elämä.[ [The Krohn Sisters: Lives in Writing.] Helsinki: Suomalaisen Kirjallisuuden Seura. 
Melkas, Kukku 2006: Historia, halu ja tiedon käärme Aino Kallaksen tuotannossa. [History, Desire, and the Serpent of Knowledge in the Works of Aino Kallas.] Helsinki: Suomalaisen Kirjallisuuden Seura.

Thurman, Judith 1982: Isak Dinesen. The Life of a Storyteller. New York: St Martin's Press. 


\title{
"And she felt the desire to speak"
}

\author{
Aino Kallas, Maie Merits, and the Female Voice
}

Aino Kallas' short story "Lasnamäen valkea laiva” [The White Ship], published originally in her short story collection Lähtevien laivojen kaupunki [The City of Departing Ships], has generally been seen as an important stage, maybe even as a turning point in the development of Kallas' literary work. One reason for this is the fact that the story ends a long silent period in her work, a period during which she desperately tried to find a new way to write; her previous writing style no longer satisfied her. As she wrote in her diary at the end of 1908: "The realistic technique that I have after a lot of work more or less acquired no longer satisfies me" (Kallas 1953, 121). Her previous work, Ants Raudjalg had been published in 1907 and two collections of short stories titled Meren takaa [From Overseas] in 1904 and 1905. All these works were traditionally realistic in their style as well as in their writing techniques. ${ }^{2}$ However, breaking out from the realistic style of writing was not easy and Lähtevien laivojen kaupunki was published in 1913 only after five "silent" years.

Reasons for Kallas' long search can be found in both her personal life as well as the social and literary worlds that changed in the early $20^{\text {th }}$ century. In 1903 Kallas had moved via St. Petersburg to Tartu. This move sealed by her marriage was crucial to her development as a writer. Through Estonian society a whole new world of thematics opened up for her, a world she made use of for the rest of her writing career. All Kallas' work apart from the autobiographical novel Katinka Rabe (1920) moves within Estonian themes. Moving to Tartu also placed Kallas permanently in between two cultures, Estonian and Finnish.

Being a citizen of two worlds, so to speak, enriched Kallas' literary expression but also caused her problems, as it meant she felt permanently homeless. Finland was no longer her home, but she also felt like a stranger in Estonia. At times, being in two places at once presented itself as insecurity, wavering and difficulty in finding her own place. Through her realistic short stories that were also critical of society, Kallas opened up new paths in Estonian literature. But even after the realistic phase, she brought new views to the Estonian literary life. Namely, she was a member of an Estonian literary group Noor-Eesti [Young Estonia] that sought to internationalise Estonian literature and bring in new thoughts to replace the old parochial 
and cliquish ones. At least in the early years, Kallas apparently also shared the literary and cultural political aims of the group.

The members of Noor-Eesti emphasized the individualism of art and also attempted to define the tasks of the artist. However, the profuse emphasis on the individualism of art and the artistic vocation, typical of the group, might have caused Kallas to feel insecure, which expressed itself as a sense of homelessness and in-betweenness. Although women's social position and political rights grew at the beginning of the $20^{\text {th }}$ century, the ideas about and attitudes towards women did not change as quickly. Kallas' correspondence shows that she experienced the division between everyday duties and creative work as extremely contradictory. In addition, being a female artist in the early $20^{\text {th }}$ century meant stepping into an area of culture that traditionally had been perceived as masculine. This might also have engendered conflicting feelings, since in order to be a "real" artist a woman had to suffocate her feminine side.

The search for a new style of writing is also inscribed in the stories in the collection Lähtevien laivojen kaupunki. The stories represent various different styles, which suggest that Kallas was trying out different writing techniques. However, the last stories of the collection, especially "Lasnamäen valkea laiva" and "Yksi kaikkien puolesta" [One For All], suggest that Kallas' stylistic search had not been in vain. In both stories it is possible already to see hints of the archaic style that later became one of the hallmarks of Kallas' writing. Particularly "The White Ship" has been seen as a turning point because of her style and writing technique (Laitinen 1973, 263-285). In addition, it has been thought to anticipate the later themes and characters in Kallas' writing, especially those of the 1920s. And the female character of the novel, Maie Merits has been seen as an older sister to the female characters of the 1920s novels such as Catharina Wycke in the Reigin Pappi [The Rector of Reigi] (1926) and Aalo in Sudenmorsian [The Wolf's Bride] (1928). ${ }^{3}$ I would, however, add one more important element to those that previous research has brought up, namely the fact that "The White Ship" is one of the first literary texts in which Kallas discusses in a particularly emphatic manner the social and political position of women.

The events depicted in "The White Ship" are based on historical events. The peasants' religious-social rebel movement that the novel describes was born in the 1850s near Tallinn, when the peasants grew weary of the unjust way they were treated. Although the movement was a rebel movement it was also from the start a religious sect, with lay preachers and people who had ecstatic experiences. The leader of the movement was a peasant Juhan Leinberg that the members called prophet Maltsvet, a title that also gave the movement its name, the Maltsvetite movement. Coaxed by Leinberg, the peasants wanted to move from Estonia. In the late spring of 1861, a large group of members gathered on the strand of Lasnamäe near Tallinn, to wait for a white ship that was supposed to take them to the Crimean region where their prophet was said to have already gone in advance. The ship, however, never arrived and slowly the movement withered away. (Laitinen 1973, 49-53.)

Kallas' short story "The White Ship" describes the life of the members during the five weeks they spent on the beach in Lasnamäe waiting for the 
white ship. Kallas is interested in the religious zeal of the group of hundreds of peasants. From the group of peasants, Kallas highlights the wife of the village merchant, Maie Merits. Maie hears a voice that tells her to join the movement. She leaves her house in the middle of her baking, leaves her husband and her children, joins the group waiting for the white ship on the Lasnamäe shore and starts to preach ecstatically the teachings of the prophet Maltsvet to the crowd. The ship, however, never shows up and slowly also Maie's visions wither away. At the end of the story, Maie returns home to her husband and children.

\section{"The White Ship" and the Bible}

There are many elements in the style of "The White Ship" that have led the Finnish literary critic Kai Laitinen to call Kallas' way of writing a myth technique. What is important for this type of technique is an archaic and biblical use of language that Kallas in this story tries out for the first time. Along with the topic of the story, its style also works to link the text to a biblical story. There are various explicit references for instance to the biblical story of the Jews enslaved by the Egyptians. Laitinen has named the myth used in the story biblical: it is a story of a mythical journey to the Promised Land (Laitinen 1973, 274).

Kallas herself, also in her diaries, mentions her exercises in biblical expression. However, although for the individual technique of mythical writing the importance of the Bible might be great, it was not uncommon for the female writers of that time to use the Bible as an intertext in their works. Kukku Melkas has shown how a similar configuration can be found in the story Jerusalem written by Selma Lagerlöf whom Kallas not only knew well but also admired, as well as in the texts of many other European female writers of the turn of the century. Rewriting of the Biblical myths was important for female writers since the Bible was thought to be one of the central means of women's oppression. (Melkas 2006, 39-40.)

The real events behind the story, as well as the story's explicit references to the Bible, have encouraged researchers to interpret "The White Ship" through its intertextual relations, and in fact these interpretations have become fairly established (cf. Laitinen 1973, Melkas 2006, Vuorikuru 2007). In these readings the intertext is, on a general level, understood as a text that is cited, rewritten and transformed into something new albeit recognizable, by another text, in this case Kallas' story (cf. Prince 2003, 46). Readings emanating from intertextuality have usually been justified by arguing that it deepens the meaning of the text and provides new insights for the reader.

In the case of "The White Ship", the intertextual connections to the Bible can, however, be problematic from the point of view of the story's complexity. The biblical model may create expectations that prevent the reader from noticing the multiplicity and richness of the text. In this sense an intertext can also limit the interpretation and in the worst case work as a reductive and deterministic force. It may condition the reading in ways 
that contort and maybe even lead astray the interpretations of the characters, actions and the end results (cf. Norris 2008, 14). Hence, it has been suggested by some scholars that interpretations that resist the making of intertextual connections might be productive. One such way of interpreting the story might be called contrasted reading in which the reader wilfully picks up elements from the text that distinguish or make it differ from its intertext (Norris 2008, 15). Contrasted reading has been applied to Kallas' story by such authors as Kukku Melkas and Silja Vuorikuru. According to Vuorikuru, the intertext that structures "The White Ship" is an old biblical myth about a trek in the wilderness and the relationship of these two texts invites the reader to reflect on the theme of an aspiration towards a utopia. In the biblical myth the crossing of the sea is a motif that unveils the side chosen by God: the chosen people of Israel walk across the sea whereas their adversaries, the Egyptians, drown. According to Vuorikuru's contrasted reading, in "The White Ship" the trek fails before it has properly begun. The water cannot be crossed. The members of the sect run to the water to greet the ship already in the evening of the first day. They stay in the water for a couple of hours but have to return disappointed when the ship does not appear. (Vuorikuru 2007, 176). Unlike Vuorikuru, Kukku Melkas has emphasized the critique of the Bible inscribed in the story, particularly from the point of view of women's position and argues that it is possible to see the story's main protagonist Maie Merits, as a female Christ figure (Melkas 2006, 42).

Although the contrasted reading does resist the meanings constructed by the intertextual connections, the interpretation nevertheless remains connected to the intertext. The biblical intertext is still the origin of the reading as well as the surface onto which the other text can be mirrored. "Virginal reading", then, has been proposed as another way of reading that resists the intertextual connections (Norris 2008, 15). Virginal reading suggests that the text is read as if the reader had no knowledge of the intertextual links within the text. In relation to "The White Ship" this means that the interpretation has to follow a path that completely bypasses the biblical references in the story. Although in practice it is most likely that pure virginal reading is impossible, especially when the story explicitly refers to its intertext, it is possible for the reader to wilfully skip the intertext offered by the text. This is exactly the way in which I will proceed to read Kallas' story in this article, since as I will show, this way of reading allows the reader to frame the story differently. The new context, which I construct in this article, opens up elements and meanings in the story that previously have not been perceived. ${ }^{4}$

\section{The voice as a theme of the short story}

The short story "The White Ship" has been characterized as a skilful and powerful description of a mass movement and mass suggestion. These characterizations have their background in the many biblical intertexts that exist in the novel (see e.g., Laitinen 1973, 274). However, many studies have pointed out 
what an important role the young wife of the village merchant, Maie Merits, plays in the novel (see Rojola 1995a and 1995b; Melkas 2006; Vuorikuru 2007). In addition to being a depiction of a mass movement the novel is also a story about a certain phase in Maie Merits' life. The importance of Maie's role as a central figure in the novel is emphasized not only by the fact that she is the only character who has a name in the novel, but also by the way in which the information about the thoughts and feelings of the movement are mediated to the reader largely in relation to the visions of Maie. Through Maie Merits, a theme, which is emphasized already at the beginning of the novel and which is essentially related to Maie's motive to join the movement, is constructed in the novel: she feels the desire to speak. When the story is examined without its biblical intertext, it becomes clear that speaking and the voice have an important role in it. "The White Ship" is saturated with themes of speech, voice, and the possibility of articulation.

At the beginning of the novel, the narrator describes in quite a detached way, a group of people and Maie performing her everyday duties. Maie's inner feelings are depicted on the one hand in relation to her children, when Maie is anxious that her children might get lost in the crowd, and on the other hand in relation to a voice she hears:

Then suddenly she was aware of a voice, clear and not be misunderstood: "See, two stand in the fields and grind, and one is taken," and her heart was filled with a great unrest on account of these words, like unto dough to which yeast is added, so that she forgot her two sons, and likewise the bread in the oven, and went indoors, staggering as though overcome by sleep. (LLK 226.) ${ }^{5}$

The voice Maie hears has exceptional power, and after having heard it Maie sinks into a kind of trance forgetting all of her previous life. Soon after, when Maie has started to follow and reached the crowd, the narrator points out: "all doubt fell from her and she felt a desire to speak" $(L L K, 227)$. This is the first expression of Maie's own desire in the short story. In the same context the narrator emphasizes that when she realizes the desire to speak, Maie also forgets her own shyness. In this sense the story tightly interweaves speaking and courage.

The structural tensions of the short story are arranged through Maie's speaking/silence. At first, when the faith in the arrival of the white ship is still great, the story depicts how a voluble stream of words flows from Maie's lips. At times Maie even shouts out in a loud voice. Towards the end of the novel, when the promised ship still is nowhere to be seen and things start going wrong for the Maltsvetians, Maie's speech also becomes more and more confused: "Maie's speech was tangled and strange at this time so that not nearly all could follow her thought, although her trances lasted longer and she could speak without ceasing for two long hours" 7 ( $L L K 248$ ). When the cultists' dream of the new life outside Estonia has come to nothing Maie says: "To-day I cannot speak" (LLK 246). Finally the words betray Maie when the body of the drowned man from Järvamaa man is brought to the shore. The cultists start to collect their things to go home, when they finally realize that their journey of hope has come to its end: 
Though no one spoke to her [Maie], she knew, sitting with bare feet in the meadow ditch, that all waited for her to open her mouth and speak. But there was no longer anything to say to them. (LLK 255.) ${ }^{9}$

Maie's important position and the meaning of the power of her voice to the members of the community is also emphasized by the fact that even in the last moments of despair the cultists wait for Maie to come up with a solution to their anxious situation. Maie, however, can no longer speak to them. Maie's last words, "[t]here is no white ship"10 (LLK 256) are of course of utmost importance to the meaning of the short story.

For Kallas to choose an ecstatic religious sect through which to study the meaning of speaking and voice, especially of woman's voice, as a topic of her novel is of course understandable. Prophets like those of the Maltsvetite sect were relatively common in early $19^{\text {th }}$ century Europe (Sulkunen 1999, 108). ${ }^{11}$ Also choosing Maie as the central character of the story is logical, since those going into a trance in religious sects were for the most part women (Sulkunen 1999, 20, 65-78). This, however, does not allow for a conclusion that spirituality in itself was somehow divided according to gender as Irma Sulkunen $(1999,100)$ also points out. Rather women, due to their social position and general social role were thought to be in a better situation to mediate those sides of the spirituality that the patriarchal society had either ignored or hidden deep into the communal consciousness as dangerous. When the hierarchical settings are turned upside down, those in the state of "madness", especially the women who had no public power nor position were best equipped to function as the mental release route for these issues (cf. Sulkunen 1999, 100). Even though spirituality is not essentially gendered, this situation, however, provided room for women's voices to be heard. In this context it is natural that Kallas chose as a building block for her short story a historical situation in which women also in reality had room to speak.

\section{The voices of literature}

Above I have pointed out the elements of "The White Ship" that clearly show the thematic importance of voice in the short story. However, I will further argue that in relation to literature in general and to Kallas specifically, voice also acquires wider meanings. In everyday speech we commonly speak of the voice of a particular writer, up to a point where we can even recognize it. However, in relation to a literary text, voice is very complex and partly also a problematic concept: the text does not actually speak; it is a silent entity and in that sense it has no voice either (see e.g., Aczel 1998). So when we ask who speaks in a literary text, we further have to ask, is it even possible to say that texts speak and if so, what are the theoretical motivations and implications of such an understanding? ${ }^{12}$ In literary criticism, voice has mostly been analysed by narratologists. ${ }^{13}$ They can, however, be criticized for analysing voice only to construct a general position of the speaker. Hence, they have written about the voice of the narrator and the 
characters as if they were separate from each other. Regardless of those many problems connected to the concept of voice in literary criticism, Richard Aczel wants to maintain its use due to the many advantages he sees in it. Aczel has started to develop the concept of voice in a way that does not imply a homogeneous position for the speaking subject and that makes it possible to connect the text to its context. For him the voice heard in literature is a configuration of borrowed speech styles, in which the importance of the reader is emphasised. (Aczel 2001, 597-598.)

Aczel bases his understanding of the voices in literature on Mikhail Bakhtin's ideas. According to Bakhtin, voice is always a formation of quotations. Multiple voices always penetrate every utterance and hence every literary text. Every text, even that of a single writer is always imbued by voices and it is not possible to connect the source of the voice to the presence of the speaker. (Aczel 2001, 599.) When we read we not only see and sense the text, but we also can always hear voices in it, even when we read quietly to ourselves (Bakthin 1981, 293). In addition, listening is always historically positioned. Therefore, in reality, the writer of the text and its reader, who eventually recreate (renew) the text, as equal participants in the creation of the world depicted by the text. The text and the world that it depicts become part of the real world and enrich it. Similarly the real world steps into the text and its world as part of the process of creation. Through the voice of the reader, the literary text is also renewed every time it is read. When the listeners/readers recreate the work, the attributes of the accents, emphases and intonations can change according to the echoes in the ears of the historical listener/reader. (Bakhtin 1981, 293; cf. also Aczel 2001, 605.)

In relation to the understanding of the voice described above, "The White Ship" and the examination of it through the concept of voice can be linked to various different levels, all of which have their own individual voice that can be heard in the story. These voices can be understood as expanding circles created by each other. In the "choir" of the story, voices of at least three levels can be found: 1) the voices in the story are related to Kallas and her personal life and work as a writer, 2) the voices in the story are tightly connected to the tradition of western literature and 3) the voices in the story are parts of the world view of Kallas and other female writers of that time and reflect women's position and the valuing of their voices. These levels are of course not separate from each other but tightly linked. The choir of the voices in the story expresses "worry" over the voice: who has a voice and what can one do with a voice? Who can speak and who cannot? The voice is thus politicised. In European women's literature these same issues have been dealt with from the end of the $19^{\text {th }}$ century and they culminate in a new narrative figure - present in the repertory of many European female writers - the woman who speaks out courageously and loudly. (Cf. Kahane 1995, viii.) 


\section{The author's voice}

The period after she wrote the realistic Estonian short stories was important for Kallas' own identity as a writer. At the end of the first decade of the $20^{\text {th }}$ century Kallas had decided to move in a new direction, only she did not know the specifics. The section called "Saarenmaalainen intermezzo" in the collection Lähtevien laivoijen kaupunki is perhaps the most obvious evidence of this search. The section includes small text exercises various in style, and the inclusion of the section in the collection was far from obvious. At the beginning of 1913, Kallas wrote that she had started to greatly doubt the miniatures, as she had titled them. They started to feel merely like simple "experiences in style" and "literary études" and she suggested to the editor that they should be left out of the collection. (Kallas 1953, 290). The editor, however, favoured their inclusion and eventually Kallas herself admitted that she was pleased that they were included.

The last stories in the collection, "One for all" and "The White Ship", however, show that Kallas was discovering a new style. Her search then, was not mere experimentation, but actually resulted in discoveries that indicated Kallas' path as a writer for a long time hereafter. In January 1913 she could already write in her diary that "[n]ow, both 'The White Ship' and 'One for all' are ready, and I know I am a writer" 14 (Kallas 1953, 285). In her statement one can hear her pride. Finishing the short story "The White Ship" convinced Kallas of her own abilities as a writer and proved that she had found her own voice distinct from other writers. Finding her own voice was for Kallas such an important event that she even prophesied about her own future as a writer by writing in her diary: "Whatever I will write in the future, I will not do it better than in "The White Ship"'15 (Kallas 1954, 41).

Written literature often presents itself as speech. Therefore, it is quite natural that the writer of a prosaic work is often considered to be its speaker. From this there is only a short step to understanding the story as an articulation of its writer. In this way literature is often rendered unproblematically into the voice of the writer that mediates his or her opinions and ideologies (Keskinen 2000, 167). This way of thinking has for a long time been seen as theoretically untenable and many literary scholars gave up the notion of authorship altogether. Feminist scholars have, however, repeatedly emphasised that the (female) author's life is always embedded within the text because gender is one of the central elements that affects ones abilities to act on the literary field. The author's life, her works and the context of their creation must be understood as a historical position, which exists as a discursive network within literary institutions (Walker 1990, 560; Parente-Čapková 2006, 197).

In response to Michel Foucault's (1969/77) famous question "What does it matter who speaks?" many feminists have referred to the fact that many concepts, such as ownership, appropriation, origin and signature work differently for men and women (cf. Miller 1988). Hence, it really does matter who is speaking. Therefore, female writers in early $20^{\text {th }}$ century Finland, often pondered the problems of female creativity and women's artistry. (Cf. Parente-Čapková 2006.) The fact that being a female artist means public 
speaking and even more importantly the courageous use of one's own voice is often emphasised in these writings.

If the voice is given the importance it deserves in the thematics of the "The White Ship", it is possible to see Maie Merits as the "alter ego" of Aino Kallas. She herself had already realised this in 1913, when she wrote in her diary: "Nowadays I could not write a single line that was not lived through in some sense. I'm not talking about confessions, which to me are only an indiscreet and cheap desire to effect" ${ }^{16}$ (Kallas 1953, 122). The lived, then, does not in Kallas' thinking mean that there would be echoes of the writer's own life in the work. Rather, what is at stake is that the literary material has been filtered through the sentiments and world-view of the writer.

For Kallas, finding her own voice meant awareness of her own artistic goals. Hence, there are places in the "The White Ship" that can be seen to refer to the artistic vocation, as Kukku Melkas has noted. Melkas has argued that when Maie preaches, she at the same time plods through the field of wheat to collect grapes for people: "She plucked grapes from the vines for them, the juice streaming between her fingers, until she herself and all around her were intoxicated with golden stream [...]"17 (LLK 239). Grapes are part of early $20^{\text {th }}$ century Russian artistic imagery, where grapes and wine functioned as the signs of an artist's creativity and ecstasy. Maie's ecstasy can be interpreted as the ecstasy of the writer, through which she pulls the listeners (readers) along (Melkas 2006, 48).

The almost exaggerated concentration on the vocation, with a complete devotion to one's art has also been connected to being an artist/writer. As has been pointed out above, this idea of vocation was also part of the ideology of the Noor-Eesti writer's group that was important to Kallas. She repeatedly refers, in her diaries and letters, to the difficulty of combining the roles of writer and mother. This conflict has also left its traces in "The White Ship". When she follows the group of the prophet Maltsvet, Maie forgets her children, her husband and the whole of her previous life. Some memories, however, penetrate her consciousness even in the midst of all the prophesising:

Maie wandered among them, and in her brain dwelt a dim remembrance of something she could not recall. Her thoughts stopped always at the moment when she felt the crowd around her, but what was beyond that moment it was impossible for her to say. At times thoughts not her own came to her, like fragments of some lost and distant being. Sitting on the shore, and watching the children roast their half-naked limbs in the sun, she felt a desire to go to them and stroke their heads, and when she half-unknowingly fondled the children's hair, the feel of it awakened in her a sense of familiar things, which she had surely lived through before, but where and when? $(L L K 238 .)^{18}$

In "The White Ship" the two roles of Maie Merits, that of public speaker and mother and wife, have been almost totally separated from each other. At the beginning of the story Maie is a silent mother and wife, who occupies herself with the duties of a housewife and is worried about her children. When Maie starts to preach - to speak - the whole of her previous life vanishes from 
her mind. In fact it seems that still at the beginning of the $20^{\text {th }}$ century, it was difficult to fit husband or children into the world of a female writer.

\section{Female voices in the literary tradition}

Through the voice of Maie Merits, Kallas' short story is positioned in the long tradition of Western literature, where the power, influence and force of the female voice has been examined in innumerable literary works. The partly mythical history of the female voice began in Ancient Greece. In Ancient mythology there are two female figures whose voices are of great importance to the whole tradition of Western literature. One of the characters is the muse the other the siren. In the ancient mythologies, both voices are emphatically female as well as extremely powerful and truth-revealing voices.

Muses were the messengers of literature in a sense that only poets could hear their voices. Poets, then mediated the messages of the muses to ordinary people, who could not hear their voices. However, even ordinary mortals could hear the voices of the other female figures, those of the sirens. Sirens are probably the most well known figures of Homer's The Odyssey. They are women whose task is very similar to that of the muses: their singing, like that of the muses, is in the original myth a story, that tells the truth about the Trojan war and its heroes. Sirens differ from muses only in that all mortals can hear their voices. This, however, has destructive consequences for mortals. As ordinary people cannot bear the truth, those who heard the Siren's song were doomed to death. The skeletons on the shores of the Sirens' island confirmed this. What is important in these mythical female figures is that originally their voice was that of epic poetry, that is, the voice of literature, which in this way proves to be female in its origins.

In the long tradition of interpretation of Western literature the significance of the Sirens' voice has however diminished. We have forgotten the element that was the semantic content of the Sirens' voice. That the Sirens sang of truth and represented the voice of literature has in the course of history disappeared from the imagery of the Sirens. Through the narrowing of the myth, the Sirens' narration has been transformed into mere singing. The interpretations started to emphasise the female voice that threatens men and hence, what is now left of the song of the Sirens is merely this terrifying voice that seduces men but whose content is not mentioned. Sirens lose their speech and become a mere voice. In the tradition that started from the Romans and continues to our days, the sirens have been seen as embodying the powerful and irresistible voice that is almost like a cry of an animal. Half women, half animals, the sirens come to represent a vocal expression that is different from the human voice (Cavarero 2005, 103).

In the Western interpretative tradition, the sirens have also undergone a bodily metamorphosis. They have become beautiful, even though in the original story their beauty is not mentioned at all. The attributes commonly attached to the female voice are also emphasised in the traditional interpretations of the siren: the female voice needs to be heeded since it contains 
elements dangerous to men. On the other hand this interpretative tradition also compels one to ask: "Is this the masculine dream of a woman in which the woman has to be beautiful, but she is not allowed to speak?" (Cavarero 2005, 106-107).

When Maie's voice is set within this interpretative tradition, it would seem that Maie in fact reproduces this diminished myth of the Sirens and the Western misogynistic tradition of the destructive power of the female/ female writer's voice. Maie's voice seduces people to wait for the white ship, for the dream guiding them to salvation. In reality, however, her voice lures them towards their destruction. Many of those waiting for the ship die, because they listen to Maie's speech. The first victims to suffer are the children. At the beginning of the third week on the shore of Lasnamäe, the son of the Kolgarand's fisherman falls ill with fever and dies. Later many other children become sick and die. From the point of view of the female voice then, the story seems quite pessimistic.

It is possible, however, to disentangle this pessimistic and perhaps also problematic interpretation, by examining the "origins" of Maie's voice. Is it really her own voice we hear when she is prophesising? Does she not simply repeat the visions she hears about from the prophet? These questions present another possible interpretation of the story. The idea of the white ship is not Maie's own dream, but is rather given to her by a prophet. It is the dream of the prophet Maltsvet that Maie only repeats. She then is not the narrator of that story, but rather an echo of a masculine voice. In this sense what is at stake is not the female voice, but masculine speech, that a woman is repeating/reiterating regardless of the fact that the female voice in the story can be seen as revolutionary. Since a woman is nevertheless speaking publicly, the story also emphasises that the woman has no voice of her own, but she simply repeats the speech given to her by the tradition. From this point of view Maie's voice is also destructive to the community. Only at the end of the novel does Maie separate her own voice from the teachings of the prophet. The sentence "There is no white ship" is Maie's own. It is her own voice that in fact is positioned in total opposition to the message of the prophet. Furthermore, if Maie's prophesising is destructive to her community, her own voice is equally destructive to the patriarchy. Maie's voice becomes "noise" that shakes the whole of the masculine system, as it eventually tells the truth, just as the voices of muses and sirens have done before. It is then possible to interpret Kallas' story as saying that if women want to speak at all, they will first have to speak with a masculine voice, since this is the only way for them to step into the public sphere. However, once there, they must start speaking with their own voices and destroy the dreams produced by the masculine tradition by stating that there is no white ship.

\section{The right to a voice}

The foregrounding of the voice in Kallas' short story makes it possible to take up a third context within which the importance of the story for the 
women's movement becomes central. One of the central topics in the late $19^{\text {th }}$ and early $20^{\text {th }}$ century social discussion was women's right to vote. In this sense the theme of the woman's voice is closely related to the demands of the women's movement. In addition, however, the right to one's own voice was part of women's demands in a larger sense as well. On a more symbolic level, the voice signified women's right to be heard not only in matters concerning them, but also in a more general sense. Due to this broader notion the voice has remained an important metaphor in feminist research even today.

Scholars have attempted to consolidate the idea that around the 1920s, the political and social perspective slowly faded in Kallas' work and the social "oppositions shine only dimly and only through few dichotomies" (Laitinen 1995, 315). In many ways this sentiment is revealing. Even though the texts do not explicitly address class or other social differences and inequalities, it does not necessarily mean that they were not political. Throughout the 1910s women's position and the problems related to being a woman started to occupy Kallas' mind more and more. If this is not understood as a social and political issue, it is clear that the question of women's social position is being undermined and not taken as a serious social and political matter.

In general, the voice is almost naturally understood to bring along the presence of the speaking subject. Therefore in feminist theories, acquiring a voice has meant not only acquiring political rights, such as the right to vote, but also in more general terms, having a larger cultural power, sexual independence and freedom of expression, all of which have traditionally been forbidden for women. In this way the voice has also become a metaphor for textual authority and is used to refer to women's efforts to reclaim their own experiences through writing. (Cf. Lanser 1992.) As a textual metaphor, voice can also be used to refer women's right to self-expression, typical or particular only to them and different from that of men. Through this is it possible to understand why the images and themes related to voice are important and why the concept of the voice has become central for the identity politics of marginalised groups.

The metaphors of voice became part of feminist theory and discussion at the beginning of Second Wave feminism, in the 1960s and 1970s. Hence, Judith Fetterley (1978), for instance, uses the metaphor of the voice when describing women's oppression. According to her what is at stake in the oppression of women is a kind of masculinisation. The concept refers to the way in which women are taught to think, experience, and interpret the world and its phenomena in a similar way to men, which results in the silencing women's own voices. Fetterley's study was published at the time when the concept of woman was still taken for granted without much theoretical problematisation. Woman's voice became in Fetterley's and also other feminists' research a sign of the original and unchanged femininity/ womanhood. Later, however, this kind of essentialist and essentialising understanding of woman has been strongly criticised, and it has been emphasised that woman as well as the "female voice" are configured through complex and ever changing conventions and in this sense a woman is 
rather something that is made than something that simply is. Regardless of the justified criticisms, the concept of the female voice has nevertheless remained as an important trope of women's independence and autonomy (Lanser 1992, 3).

Following Fetterley's ideas, it is possible to see Maie Merits as a victim of masculinisation. Maie repeats the message of the prophet Maltsvet. She speaks with a masculinisised voice, not with her own. Maie and the other women in the story start to observe and interpret the world in the way proposed by their prophet. The masculinisised female speaker is possessed by an alien (male) spirit that silences the original (female) voice. Through the disappearance of her voice, Maie Merits herself also disappears. This notion of disappearance is further supported by the way in which Maie in a sense denies herself, when the question of her identity arises:

But many around her made inquiry: "Who is this?" And others answered: "She is not of the Maltsvets, as her dress is of many colours and her hair is plaited." She made answer to them all: "Why do ye ask? I am no one; I have neither name nor children, neither husband nor home." (LLK 227-228)19

Silja Vuorikuru $(2007,183)$ has argued that the use of the negative formulae ("I am no one") in the above quotation, expresses the shedding of the previous chains of life, such as the responsibility of the mother and the name received from the husband. This interpretation is of course further supported when Maie actually lists these exact things - children, husband and house - and then proceeds to deny them. When the woman leaves the place the cultural system marked as "natural" for her (i.e. from home), there will be nothing left of her anymore. She does not even have a name. In this sense finding the prophet's voice meant for Maie the vanishing and the death of the self. When a woman starts to speak publicly, she simultaneously disappears as a woman. The story then emphasises the asymmetry that exists between the voices of women and men in our cultural practices: the woman who speaks publicly is no longer a woman.

Vuorikuru has further pointed out that the Maltsvetite utopia is distinctively a women's utopia. Women are depicted as strong, visible and loud; they speak publicly in the camp. (Vuorikuru 2007, 182.) It is true, that the women are distinct within the group that waits for the white ship. They are perceived as individuals even though only Maie Merits' name is mentioned. However, women are also active in other ways. A blind old woman who, while waiting for the ship, watches the sea with eyes that no longer see is mentioned several times as is the mother of Kolgarand's dead child. When her child dies, she begins to criticise the whole project of waiting for the ship:

[...] she was still more dissatisfied, beginning to complain in a loud voice and say she needed no white ship, but wanted her son back again, whose sickness was a result of the cold and wet nights. But her husband, who was pious and Godfearing, hurriedly silenced her before she could heap upon sin, and after that she dared no longer to speak her thoughts aloud, her lips moving instead in a silent babble of words that none understood. (LLK 242-243. $)^{20}$ 
At this point, however, the mother of the dead child does not yet question the existence of the white ship. She merely points out that it is not needed. In any case, the first voices doubting the sense of waiting for the ship are women's voices. When the male speech proves to be lies, Maie becomes conscious of her condition. Hence, before Maie can become conscious of her own place, before she can become a conscious, speaking subject, the male speech has to be proven a lie. In the end of the story she speaks with her own voice as well as with the voice of the other women and tells the truth: there is no white ship. Although Maie Merits in the story is chosen as an individual from the group of those waiting for the ship, the story simultaneous emphasises that Maie's experience is not unique in a sense of being individualistic:

[...] she felt the longing of all those hundreds flow into her until her soul seemed overfull. She seemed herself to disappear, as though the boundaries of her soul and body had given way; her spirit dissolved to nothing, and she was lost with it, but suddenly life awoke within her for all who stood around, drooping and in pain, with a great and bitter yearning. (LLK 235. $)^{21}$

The fact that Maie previously, having been asked who she is, has answered that she is no one, does not have to be interpreted as a "disappearance of the self" (cf. Vuorikuru 2007, 183) and as such, a negative thing. It is also possible to argue that what vanishes in the story, is only the Western, individualistic concept of the self and that the story in fact suggests a replacement for it. This replacement resembles the notion of the voice familiar from the writings of Bakhtin. As I have pointed out above, Bakhtin argues that many voices penetrate each utterance. The individual and his/her voice are never single but always in relation to multiple others that constitute the voice that we hear. It is then possible to understand the voice of Maie as imbued with the voices of all oppressed and silenced women, even if the voice on the surface is Maie's.

In Kallas' story women are marked out as a group of their own. Women and their children are the first ones to throw a shadow of doubt on the whole project of waiting for the ship. It is possible that at first waiting for the ship was also women's utopia, as Vuorikuru $(2007,182)$ has argued, but very soon they notice that for them and their children the waiting simply means suffering. A particularly good example of this is the death of Kolgarand's two-year-old son:

But in the beginning of the third week the two-year-old son of a fisherman from Kolgarand fell ill with fever and convulsions and died in the lap of his mother, who wailed and stormed alternately. Her husband nailed short unplaned boards together, and bore the coffin on his shoulder to the town, but the mother followed behind, and the white ship in which her little son was leaving her gave her no joy. $(L L K 242 .)^{22}$

The story emphasises that waiting for the white ship is men's utopia. For women, men's white ship proves to be nothing more than a child's coffin rigged up from a couple of unplaned boards. 
"The White Ship" has often been interpreted in a rather pessimistic way as a story in which dreams are just illusions that eventually die. We know that Maie returns home to her children and her husband, but in fact we do not know what kind of Maie it is that returns. The pessimistic interpretations have been based on the assumption that Maie simply returns to her previous role as a dutiful, obedient and above all silent (mute) wife. In reality, however, the story does not support this kind of interpretation. In fact it takes a lot of courage to announce that the ship does not exist. Maie is no longer the shy and quiet young wife that once left home. She has learned a bitter lesson with the prophet Maltsvet. It is no good for women to believe in the dreams created by men, but rather they have to courageously tell the truth no matter how bitter. Equally it is possible to read in the story a suggestion that women need to built their own dreams and speak about them with their own voices.

\section{Notes}

1. [Realistinen tekniikka, jonka niin suurella työllä olin jossain määrin omaksunut, ei tyydytä minua enää.]

2. In these collections of short stories Kallas describes the history of Estonian peasants as a history of fatigue, whipping and failed rebellions. See, e.g., Vuorikuru 2007, 185.

3. Maie's role as the "big sister" can now be questioned, though, because Silja Vuorikuru has found the manuscript of Bathseba, which Kallas most probably wrote in 1909-1910. This text presents a protagonist who in many ways resembles both Maie Merits and Kallas' other female characters. Cf. Vuorikuru's article in this collection.

4. About the significance of the contextualization for feminist literary criticism, see Rojola 2004, 36-38.

5. [Silloin hän kuuli jonkun sanovan selkeällä ja tajuttavalla äänellä: "Katso, kaksi jauhattavat kedolla, ja yksi otetaan", ja samalla hänen sydämensä täytettiin suurella levottomuudella, näitten sanojen johdosta, ikäänkuin taikina, johon hapatus heitetään, niin että hän unohti tykkänään poikansa, niin myös leivät uunissa, ja meni sisään, hoiperrellen kuin puoliunessa.] Reference is to the collection Lähtevien laivojen kaupunki [The City of Departing Ships], referred to as $L L K$.

6. [...haihtui hänestä yhtäkkiä kaikkinainen epäily, ja hän tunsi haluavansa puhua, ...]

7. [Maien puheet olivat sekavia ja outoja näinä aikoina, niin etteivät lähestulkoon kaan kaikki niitä oivaltaneet, vaikka hänen loveenlankeemisensa kesti nyt entistä kauemmin, ja hän taisi puhua pari tuntia yhtämittaa.]

8. [Minä en voi puhua tänään.]

9. [Vaikka ei kukaan sanonut, tunsi hän kuitenkin, istuessaan paljaat jalat niittyojassa, että kaikki odottivat hänen avaavan suunsa ja puhuvan. Mutta hänellä ei ollut heille mitään sanomista.]

10. [Valkeaa laivaa ei ole.]

11. Also in Finland many ecstatic religious sects were born from the latter half of the $18^{\text {th }}$ century onwards, as Sulkunen (1999) has shown.

12. The theoretical aspects of literary voice have gained wide interest especially among cognitive narratologists. The magazine New Literary History published one issue 
$(32,2001)$ dedicated to the problems of the voice.

13. One of the most important scholars developing the concept of voice has been Gérard Genette (1980), who wanted with the concept of voice to answer the question "who speaks?" in literary work.

14. [Nyt ovat siis "Lasnamäen valkea laiva" ja "Yksi kaikkien edestä" valmiit, ja minä tiedän olevani runoilija.]

15. [Mitä minä vastaisuudessa tulenkin kirjoittamann, oikeampaan en voi osata kuin "Lasnamäen valkeassa laivassa".]

16. [... en voisi enää kirjoittaa riviäkään, joka ei olisi elettyä jossain merkityksessä. En puhu tunnustuskirjallisuudesta, jossa näen usein vain epähienoa, koristelevaa ja halpaa efektinhalua.]

17. [... ja nyt hän riipi heille rypäleitä, ja niitten mehu vuosi pitkin hänen sormiaan, ja hän itse ja he kaikki huumaantuivat tästä kultaisesta mehusta...]

18. [Mutta Maie kulki heidän keskellänsä, ja hänen aivoissaan hämärsi tieto jostakin, mitä hänen oli mahdoton muistaa. Hänen ajatuksensa pysähtyivät alati hetkeen, jolloin hän tunsi ihmistungoksen ympärillään, mutta mitä sen tuokion takana oli, ei hän tiennyt. Joskus tuli hänelle ajatuksia, joita hän ei omikseen tuntenut, ikäänkuin mureneina jostakin kadonneesta ja kaukaisesta olennosta. Istuessaan rannalla ja nähdessään lasten paahtavan puolipaljaita jäseniään hiekassa, hän halusi mennä ja silittää heidän päätään, ja kun hänen sormensa hajamielin haroivat lasten hiuksia, herätti hiusten hipaisu tutun tunnon, jonka hän varmasti oli ennenkin elänyt, mutta missä ja milloin?]

19. [Mutta monet hänen ympärillään kysyivät: "Kuka tämä on?” Ja toiset vastasivat: "Ei hän taida olla maltsvetien parista, sillä hänen hameensa on kirjava, ja hiukset palmikolla." Silloin hän vastasi kaikille yhteisesti: "Miksi te kysytte? Minä en ole kukaan, minulla ei ole nimeä eikä lasta, ei miestä eikä kotia."]

20. [... hän oli vieläkin tyytymättömämpi ja alkoi napista suurella äänellä ja sanoa, ettei hän tarvinnut mitään valkeaa laivaa, vaan tahtoi lapsensa takaisin, joka oli saanut taudin kosteudesta ja yökylmästä. Mutta hänen miehensä, joka oli hurskas ja jumalaapelkääväinen, sulki kiireesti hänen herjaavan suunsa, ennenkuin se ennätti enempää syntiä tehdä, eikä hän sen jälkeen enää uskaltanut mitään ääneen puhua, mutta hänen huulensa liikkuivat lakkaamatta, sopottaen sekavia sanoja.]

21. [Silloin hän tunsi, kuinka kaikkien näitten satojen ihmisten ikävä ikäänkuin valui häneen, kunnes hänen sielunsa kävi ahtaaksi. Hän itse hävisi, kuoli pois, ikäänkuin hänen ruumiinsa ja sielunsa rajat olisivat murtuneet, hänen elämänsä haihtui olemattomaksi, ja hän itse sen keralla, mutta yhtäkkiä elivät hänessä kaikki, jotka hänen ympärillään riutuivat kipeästä ja ylensuuresta odotuksesta.]

22. [Mutta kolmannen viikon alussa sairastui erään Kolgarannan kalastajan kaksiajastaikainen poika kuumeeseen ja kouristuksiin ja heitti henkensä äitinsä vuoroin vaikeroidessa ja soimatessa. Hänen miehensä naulasi kokoon pari lyhyttä, höyläämätöntä laudanpätkää ja kantoi kirstun olallaan kaupunkiin, mutta äiti seurasi taampana eikä ollut tyytyväinen lapsensa valkeaan laivaan.] 


\section{References}

\section{Research objects}

Kallas, Aino 1913/1995: Lähtevien laivojen kaupunki. [The City of the Leaving Ships.] Helsinki: Suomalaisen Kirjallisuuden Seura.

Kallas, Aino 1953: Päiväkirja vuosilta 1907-1915. [Diaries From the Years 1907-1915.] Helsinki: Otava.

Kallas, Aino 1954: Päiväkirja vuosilta 1916-1921. [Diaries From the Years 1916-1921.] Helsinki: Otava.

\section{Research literature}

Aczel, Richard 1998: Hearing Voices in Narrative Texts. New Literary History 29: 3.

Aczel, Richard 2001: Understanding as Over-hearing: Towards a Dialogics of Voice. New Literary History 32: 3.

Bakhtin, Michael. M. 1981: The Dialogic Imagination. Austin and London: University of Texas Press.

Bal, Mieke 2002: Travelling Concepts in the Humanities. A Rough Guide. Toronto: University of Toronto Press.

Cavarero, Adriana 2005: For More Than One Voice. Toward a Philosophy of Vocal Expression. Stanford: Stanford University Press.

Connor, Steven 1999: The Ethics of the Voice. In: Dominic Rainsford and Tim Woods (eds.), Critical Ethics. Text, Theory and Responsibility. Houndmills et al.: Macmillan Press.

Fetterley, Judith 1978: The Resisting Reader. A Feminist Approach to American Fiction. Bloomington: Indiana University Press.

Foucault, Michel 1969/1979: What is an Author? In: Josué V. Harari (ed.), Textual Strategies in Post-Structuralist Criticism. London: Methuen \& Co.

Genette, Gérard 1980: Narrative Discourse. An Essay in Method. Ithaca: Cornell University Press.

Kahane, Claire 1995: Passions of the Voice. Hysteria, Narrative, and the Figure of the Speaking Woman 1850-1915. Baltimore and London: Johns Hopkins University Press.

Keskinen, Mikko 1999: Emännän ääni: Feministit ja gynofonosentrismi. [The Voice of the Housewife: Feminists and Gynophonosentrism.] Naistutkimus-Kvinnoforskning 4 .

Keskinen, Mikko 2000: Kuultava kirjoitus: ääni ja puhe kirjallisuudessa. [Writing to be heard. Voice and Speech in Literature.] In: Katriina Kajannes \& Leena Kirstinä (eds.), Kirjallisuus, kieli ja kognitio. Kognitiivisesta kirjallisuuden- ja kielentutkimuksesta. [Literature, Language and Cognition. On Cognitive Linguistic and Literary Studies.] Helsinki: Yliopistopaino.

Laitinen, Kai 1973: Aino Kallas 1897-1921. Tutkimus hänen tuotantonsa pä̈linjoista ja taustoista. [Aino Kallas 1897-1921. Research on the Main Topics and Background of her Work.] Helsinki: Otava.

Laitinen, Kai 1995: Aino Kallaksen mestarivuodet. Tutkimus hänen tuotantonsa päälinjoista 1922-1956. [The Master Years of Aino Kallas. Research on the Main Topics and Background of her Work 1922 -1956.] Helsinki: Otava.

Lanser, Susan Sniader 1992: Fictions of Authority. Women Writers and Narrative Voice. Ithaca and London: Cornell University Press.

Leskelä-Kärki, Maarit 2006: Kirjoittaen maailmassa. Krohnin sisaret ja kirjallinen 
elämä. [The Krohn Sisters: Lives in Writing.] Helsinki: Suomalaisen Kirjallisuuden Seura.

Melkas, Kukku 2006: Historia, halu ja tiedon käärme Aino Kallaksen tuotannossa. [History, Desire, and the Serpent of Knowledge in the Works of Aino Kallas.] Helsinki: Suomalaisen Kirjallisuuden Seura.

Miller, Nancy K. 1988: Subject to Change: Reading Feminist Writing. New York: Columbia University Press.

Norris, Margot 2008: Odysseia-intertekstin vastustamisesta Joycen Odysseuksessa. [On Reading Against Ulysses intertextuality in Joyce's Ulysses.] Kantola, Janna \& Pyrhönen, Heta (eds.), Homeroksesta Hessu Hopoon. Antiikin traditioiden vaikutus myöhempään kirjallisuuteen. [From Homer to Hessu Hopo. Influence of the Traditions of Antiquity on Later Literature.] Helsinki: Suomalaisen Kirjallisuuden Seura.

Parente-Čapková, Viola 2006: Feminisoitu estetiikka ja naistekijyys. Naistekijäksi tulemisen mahdollisuudet L. Onervan varhaisteksteissä. [Feminized Aesthetics and Woman's Authorship. Possibilities of Becoming a Woman Author in Aino Kallas' First Works.] In: Kaisa Kurikka \& Veli-Matti Pynttäri (eds), Tekijyyden tekstit. [Texts of Authorship.] Helsinki: Suomalaisen Kirjallisuuden Seura.

Prince, Gerald 2003: Dictionary of Narratology. Lincoln: University of Nebraska Press.

Rojola, Lea 1995: Naisen kieli ja hysteria. [Female Language and Hysteria.] In: Blomstedt, Jan \& Lõhmus, Maarja \& Tarasti, Eero (ed.), Ajan arvot \& sankarit. [Values \& Heroes of Time.] Tartu; Greif. (1995a)

Rojola, Lea 1995: Omaa ääntä etsimässä. Esipuhe Aino Kallaksen novellikokoelmaan Lähtevien laivojen kaupunki. [Searching for One's Own Voice. Foreword to Aino Kallas' Short Story Collection The City of Leaving Ships.] Helsinki: Suomalaisen Kirjallisuuden Seura. (1995b)

Rojola, Lea 2004: Sukupuolieron lukeminen. Feministinen kirjallisuudentutkimus. [Reading Sexual Difference. Feminist Study of Literature]. In: Marianne Liljeström (ed.): Feministinen tietäminen. Keskustelua metodologiasta. [Feminist Knowledge. Discussion on Methodology.] Tampere: Vastapaino.

Sulkunen, Irma 1999: Liisa Eerikintytär ja hurmosliikkeet 1700 -1800 -luvulla. [Liisa Eric's Daughter and Ecstatic Religious Movements in the $17^{\text {th }}-18^{\text {th }}$ Century.] Helsinki: Gaudeamus.

Vuorikuru, Silja 2007: Minä ikävoin maahan, jota ei ole. Utopia Aino Kallaksen novellissa "Lasnamäen valkea laiva". ["I am longing for the country which does not exist." Utopia in Aino Kallas' Short Story “The White Ship".] In: Rossi, Riikka \& Seutu, Katja (eds.), Nostalgia. Kirjoituksia kaipuusta, ikävästä ja muistista. [Nostalgia. Writings on Longing, Sorrow and Memory.] Helsinki: Suomalaisen Kirjallisuuden Seura. 


\title{
From Apocalypse to the New Paradise
}

\author{
Early Ecological Thinking and Aino Kallas' Work \\ in the $1920 \mathrm{~s}^{1}$
}

Multa sunt in natura nobis ad hoc ignota.

Aino Kallas' short story Pyhän joen kosto [the Revenge of the Holy River] ${ }^{2}$ was published in 1930. The quotation above is one of the last sentences of the story. It leaves the reader in a state of uncertainty. The Latin verse means: Many things in nature are still unknown to us. The narrator's voice notes that humans' knowledge is always somehow partial concerning nature. It also suggests the helplessness of man: although many technological advances have happened and science has made giant steps, we have to confess that we do not really know nature; it always remains somewhat strange and unknown. (Comp. Haila 1999, 264.)

In the Finnish literary field in the 1920s we can see traces of new ecological thought that arose after the destruction of the First World War and the ongoing massive industrialisation of the world. Kallas' apocalyptic work ${ }^{3}$ has the same kind of thematic as those of her Finnish contemporaries: F.E. Sillanpääs debut novel Elämä ja aurinko [The Life and the Sun] (1916), Pentti Haanpääs Tuuli käy heidän ylitseen [The Wind Will Blow Upon Them] (1927) and Katri Vala's Kaukainen puutarha [A Distant Garden], (1924), in which nature is not seen through humans but instead, humans through nature. (Cf. e.g. Häggman 2001, 250-252; 338-342.) These writers pondered and defined the relationship between humans and nature at the same time as the modern world and its changes meant ever-growing industrialism and new technological innovations. A specific feature in Kallas' work is the strong connection between femininity and nature. This connection and its different implications in its own time context can be read as part of early ecological thought.

\section{New paradises - new orders}

The most prominent and influential conception of nature in Western philosophy of history is one that is based on difference and binary opposites; na- 
ture is seen as a necessity positioned outside of culture and humanity (Haila and Lähde 2003, 19; Plumwood 1993). The modern conception of nature is furthermore bound up with notions of appropriation, exploitation and control. A different conception centres on the way in which nature represents freedom and on the imagined harmonious relationship between primitive human beings and nature. These two influential views on and approaches to nature have facilitated the development of myths which affect the way in which nature is still conceptualised in Western thought (Williams 2003, 40-49; Haila and Lähde 2003, 19-20; Lehtonen 1994, 56-57). Raymond Williams sees the dualistic conceptual framework, on which binary oppositions are based, as a problematic constraint within Western thinking. The conception of dualism as a constraint has also been tackled by numerous feminist philosophers (see e.g., Plumwood 1993, 41-68; Lloyd 1984/2000; Suutala 2001). The negative implications that dualism has specifically for sex emerge in the hierarchical pairs of opposites which structure Western thinking and epistemology.

Proving that women are closer to and more integrally bound up with nature simultaneously legitimates their exclusion from culture. It is this division that Kallas and women writers contemporary with her were trying to break down and redefine in their works. Although ecofeminism (see Sturgeon 1997, 23-58; Plumwood 1993; Garrard 2004, 23-27) and concern for the environment only became highly topical and emerged as political movements in the 1970s, it could be argued that stances on ecological questions were already being formed in literature when these questions first arose. A contemporary of Kallas, the Swedish writer Elin Wägner (1882-1949), tackled ecological issues in her 1941 pamphlet Väckarklocka [The Alarm Clock]. ${ }^{4}$ The novel explores the connections between ecological problems, capitalism and patriarchy and the problems induced by these connections. As Katarina Leppänen has stated in her thesis, Väckarklocka

is an attempt to analyse both how the exploitation of women and the subjugation of nature has been part of the creation of a patriarchal system, and how the system, through its norms, symbols and institutions in turn affect both women and nature. Recognising this connection without trying to detach nature from the category of woman, but instead trying to see nature as an important part of being human, is Wägner's most interesting contribution to ecofeminist thinking. $(2005,211-212$.)

Wägner's critique of civilization and early ecofeminist thinking, have been associated with the social criticism of the Austrian feminist Rosa Mayreder (Leppänen 2005, 48-50, 128-133, 202-207), which is interesting concerning Kallas.

Rosa Mayreder's Zur Kritik der Weiblichkeit (1905) was written as a response to Otto Weininger's popular book Geschlecht und Charakter (1903), which Kallas, too, comments on in her short story "Nainen, jolla oli aivot" [A woman who had brains] (1912). In opposition to Weininger and other misogynist writers of the time who saw the feminisation of society as the cause of its ruin and decay, Mayreder argued that it is precisely the feminine 
influence that is still able to rescue civilisation from collapse (Leppänen 2005, 48-50). Perspectives on ecological issues, then, were being articulated in literature in the context of writing which intertwined many different but concurrent phenomena and events in the cultural sphere. The most influential of these were the First World War and the rise of militarism, an uncritical belief in technology, socio-political upheavals and the rise of the Women's Movement. In these ways, the relationship between humans and nature in Wägner's and Kallas' works is perceived and constructed in a way which is radically different from what is usually found in Western discourse on the relationship with nature (Leppänen 2005, 202-224; Melkas 2006, 254-301; cf. Merchant and Peterson 1996). Rather than centring on exploitation, the relationship between humans and nature in these writers' works centres primarily on a striving for harmonious co-existence.

Kallas' historical short story, "Gerdruta Carponai" from the collection Strange Blood is a tale of a priest's daughter in Saaremaa (Estonia) during the plague epidemic in the $18^{\text {th }}$ century. ${ }^{5}$ The entire congregation is killed by the plague and the priest's daughter is the only remaining inhabitant in the parish. After wandering, exhausted, for days she finds human footprints on the shore and meets a young fisherman. The story inverts the Biblical myth of Paradise: all the essentially negative features of the myth are reinterpreted or openly associated with positive motivations. In "Gerdruta Carponai", the apocalyptic world view introduced by the plague is associated with the potential of rebirth: after chaos (the plague) it is possible to create a new order.

Instead of symbolising sin and seduction, the Serpent in "Gerdruta Carponai" is a positive motif and a metaphor for fertility. When Gerdruta and the young fisherman, Kadariku-Laes, meet the serpent, he does not kill it but tosses it over his shoulder, explaining how, according to a popular belief, the serpent brings fertility and a good crop. Since the paradise-myth essentially defines female sexuality as original sin, the serpent can also be seen as symbolic of feminine fertility and, consequently, sexual desire. This interpretation is supported by the different symbolic significances the serpent has had at different times in history: while the pre-Christian era saw the serpent as the symbol of the goddess, the Bible and the Fall turned it into a symbol of evil knowledge and sinful sexuality (Järvinen 1997, 106-117). Through these fractures of significances the short story points to different knowledges: with the knowledge of this commoner, Kadariku-Laes, it is possible to live in a harmonious relationship with nature. Gerdruta and Laes live their short moments in this new paradise when everything starts anew after the end of the world.

The fractures in the significances of the symbolic serpent also touched upon the concepts of femininity and masculinity: in earlier cultures and belief systems the serpent was a potent symbol of feminine fertility, but it gradually became a phallic symbol in European folklore, reaching this masculine pinnacle in the writings of Freud at the beginning of the twentieth century. In any case, in "Gerdruta Carponai" the serpent foreshadows the presence of sexual desire between Gerdruta and Kadariku-Laes.

This interpretation finds support at the end of the story, where we are told that Gerdruta was later to pay for her sin on the church "whore's 
bench". What was defined as a sin was her behaviour: having intercourse with a man below her status and giving birth to his five children without the blessing of the church, namely, marriage. Through the power structure (the church) female sexuality is integrated into and made part of the prevailing order, where it is defined as socially threatening, and is therefore subject to control. The end of the story stresses the point that the mother herself (Gerdruta) is forgotten by history but that it was from her that the new and stronger family in Saaremaa had sprung. In this way Kallas comments on the Biblical story of the Fall, by creating a positive and productive counter-image of the woman by combining the element of the first mother with that of sexuality.

The use of the paradise-myth and mixing of folkloristic material with Biblical themes are in fact not strange at all considering the atmosphere at the beginning of the twentieth century and the emphasis in women's movements. There was an increasing interest in traditions and the past among women intellectuals while they were producing stories of themselves and feminism. Suffragettes also viewed the past "as a potential source of inspiration and symbolic strength" (Felski 1995, 166). The yearning for the past, according to Rita Felski, in women modernists' work can be seen as an active attempt "to construct an alternative future, so that nostalgia comes to serve a critical rather than a simply conservative purpose" (Felski 1995, 59). The re-writing of Paradise myth and the story of the Fall can also be interpreted as part of the new conceptualisation of the relationship between humans and nature, as we will see in the next chapter.

\section{Nature as woman and man as the conqueror}

It happened anno 1640 that Master Adam Dörffer, mill builder from Arnstadt in Germany, received an urgent request from Master Hans Ohm to come to Livonia in order to build a water mill in the river Võhandu by the Mansion of Sõmerpalu. And thus got their start all the excellent and unprecedented affairs which excited people's minds with great impetuosity for nearly two years and finally led to an abomination of desolation, a loss of human lives, severe punishments and a great scream. (PJK, 38. Translation Paavo Castrén.) ${ }^{6}$

Kallas' story "The Revenge of the Holy River" is a historical tale that is situated in Estonia in 1640. Kallas had already in her previous work in the 1920s (Eros the Slayer trilogy 1923-1928), as well as in "Gerdruta Carponai" (1921), used the means of historicising and distancing that enabled her to observe contemporary questions and phenomena from a distance. The beginning of the short story foretells immediately coming events: an ecological catastrophe, which is caused by the main hero, Adam Dörffer, and the watermill he planned and built. At the same time there is a reference to the last book of the Bible (the Apocalypse) where everything ends at the "abomination of desolation and a great scream". It is quite interesting that the first and last books of the Bible have been defined as the "ark texts" or basic texts of ecocritical literature. They have worked as the basic texts in 
modern ecocriticism when writers have sketched ways to imagine humans' place in nature. (See Buell 2005, 13-23; Garrard 2004, 85-107; Lahtinen 2005, 14-16; c. Lyytikäinen 1999, 206-221.)

But what causes the ecological catastrophe in Kallas' short story and why does the river take retaliatory actions? The main hero in the story is the master of new technological knowledge: a skilful architect of new mills. The hero is also compared with God in the text when the readers are told that his works were always unique as are the works of God. In addition to this the name of the hero, Adam, connects him to the first man on earth (the myth of creation). So, in the beginning of the story he represents a kind of prototype of a strong and self-conscious masculine hero. Adam himself also connects himself to his namesake from the myth of creation in the story. This reference underlines man's superiority over nature and woman: Adam's mission in Livonia is not only to build the new watermill but also to dam up the Holy River of Võhandu that is compared with a pure maiden $(P J K, 95)$. Little by little, there develops an eroticised relationship between the master and the river and this tight and problematic relationship can be read as the one between a man and nature.

An early natural scientist, Francis Bacon (1561-1626), in his theory of epistemology defined nature as a feminine mystique and yet knowable and able to be controlled. According to a feminist philosopher Genevieve Lloyd, Bacon's insights and metaphors have had a strong influence on how the notion of femininity has been moulded in connection with the ideal ways of knowing and what is valid knowledge. The ideas of objective knowledge in other words are constructed through certain conventions and rules. These conventions and rules are guided by such thinking that excludes everything culturally defined as feminine. (Lloyd 1984/2000, 35-41; see also Keller 1988.) When the terms of knowing are constructed upon gendered metaphors and concepts the terms are also in many ways defined as exclusive practices of producing knowledge.

There is also a strong eroticised system of control that has been constructed into the symbolic of the natural sciences. Bacon's aforementioned language of natural sciences was based on various attempts to control and oppress nature. In addition to this eroticisation, what is at stake, then, is conquering and controlling nature. Nature had to be harnessed for the use and benefit of humans. Indeed, the ways in which this harnessing was executed were often violent. The use of sexual metaphors in the control of nature also conjoined woman and nature (Lloyd 1984/2000, 36; see also Soper 2000, 140-141) and, in addition, knowledge came to be understood as the mastering of nature/woman.

The description of the encounter between the master and the river in the "Revenge of the Holy River" follows the eroticised pattern of conceptualising nature, where nature is seen as an object and a tool. During the progress of the story, the river is continuously given attributes that are culturally coded as feminine. Dörffer's desire to build a mill and subjugate the river also includes a sexual or erotic desire. The whole task is driven by man's boisterous and passionate relationship to his work and the erotically laden system of control is emphasised: 
And as Master Adam Dörffer every morning passed by the weir he reflected maliciously Võhandu's reluctant waters which were supposed to be swelled by the weir in order to serve obediently his will and the mill, to grind the grain and to run the sawmill.

This thought filled his mind with such lust as if a beautiful and capricious and unconquerable woman had been at stake and occupied to such extent his time that he forgot against his normal habits all love businesses and did not employ an encouraging bedpartner as he always had done during his first week in the new working place. (PJK, 114-115. Translation by Paavo Castrén. $)^{7}$

Dörffer aims to make the involuntary waters of the river follow according to his will. These violent associations contrast with the sexual desire when the paragraph points out that Dörffer does not, this time, get a lover for himself. The harnessing of the river produces the master's great satisfaction, and in order to show his defiance to the commoners, who believe the river to have a soul, the purity of which needs to be protected, he metaphorically rapes the river by throwing a dead dog into it.

In addition to pointing to these gendered conceptions of nature and the ideology of the exploitation of nature, Kallas' "The Revenge of the Holy River" in fact also dismantles these conceptions and works towards creating an entirely new conception of nature. In the story the river is given strangely human qualities. For the commoners of the village, the river has a soul, which for them symbolises a nourishing and vital mother who is also powerful and sacred. The river is told to have a longing for freedom, the omnipotent power to regulate the growth of crops by the riverbanks and an unconditional demand for purity. Because of this belief, a powerful confrontation is built into the novel between what is known as folk knowledge, or knowledge based on experience, and expert knowledge.

While the character Adam Dörffer is intent on exploiting the river to the fullest, the common people would prefer to let it stay as it is. The confrontation between the expert and the ordinary people pits two different conceptions of nature against one another: the anthropocentric, exploitative view of nature in Christianity against the pagan belief system in which nature is respected and considered sacred (cf. e.g. Lahtinen 2005, 11), as was also the case in "Gerdruta Carponai".

The omnipotence and vindictiveness of the river is revealed in the threat made to Dörffer, in which the river "speaks" to him and reminds him that he should never have imprisoned her. The imprisoning will cause a punishment and the river "says" it will be the master's death. In a sense, the ecological catastrophe caused by the building of the mill (the river floods and destroys the farm lands, causing a famine in Livonia) calls for revenge.

The river becomes boisterous and emancipated; it starts to flood all over the farmlands. At the same time, the order of nature is disturbed:

But this was indeed the beginning of the end, and the shadow of the Great Famine fell over the country like the shadow precedes the steps of an arriving wanderer. For this excellent and strange weather, which was against all nature's order, as if the stars and the Elements themselves would have instigated a revolu- 
tion, reached Latvia and Finland and further over Pskov and even the borders of Olonetz. And it seemed to prove what God had proclaimed through the mighty prophet Jeremiah. (PJK, 86. Translation by Paavo Castrén. $)^{8}$

Kallas' river, in fact, goes through a metamorphosis in which a traditional, lovely and seductive mermaid, depicted by the previous art iconography (cf. Niinisalo 2006), is transformed into an angry and powerful woman. The connection between woman and nature is constructed in relation to sexualised and gendered conceptions of nature and, through a re-imagining, it gains new meanings. While, in the hegemonic imagery of the natural sciences, nature has played the role of the object of oppression and the use of power, its articulation in Kallas' work is different: it is connected to the power of nature, characterised as feminine, and to the defence of woman's independence.

\section{The Apocalypse and the rebirth of the masculine hero}

The metamorphosis is, however, endemic not only to the sacred river, but it also relevant to the story's main character Adam Dörffer. Little by little, this action hero starts to lose his grip on the mill project that he planned and executed. The river starts to lure him and draw him to itself and soon the hero's faith in his own knowledge and its right to exists starts to falter. While riding on a summer's night "an unexplained desire stirred in him" [niin hänessä heräsi selittämätöin halu] $(P J K, 128)$. At the well, Dörffer hears someone talking to him and notices a young maiden on the other side of the well. When Dörffer asks why the girl is sitting at the well washing her face, she answers: "Don't you know, stranger, that this is the sacred well of Vöhandu?" [Etkös tiedä, muukalainen, että tämä on Võhandun Pyhä lähde] (PJK, 132).

In addition, the maiden warns Dörffer of the danger existing within the river, threatening everyone that tries to imprison and make use of it. Frightened, Dörffer feels insecure for the first time: he does not know if he should believe his eyes and attempt to reach the maiden who, nevertheless, disappears. Little by little, the inexplicable and mythical events raise doubts about the rationality of the mill project in the mind of the hero; however, fearing the loss of his honour, he stubbornly continues the task he had begun. Concurrently, the rationality originally built in to Dörffer's character begins to shatter. During the process, he becomes doubtful and contemplative and, finally, the river has enchanted him so that he falls in love with it.

The masculine hero goes through a gradual metamorphosis that is referred to in the statement: "so, Adam Dörffer was from this morning a new man"9 (PJK, 167). Eventually, Dörffer's character is extremely contradictory and it is here that the story's actual message lies. Regardless of his stubborn and demeaning refusal to accept beliefs and explanations, in the end, he is the one who really believes in the existence of the river's soul. During his nightly rowing trip, he maintains a "dialogue" with his heart and asks insecurely how the humanity of the river is even possible. Reason has been the 
hero's guide in all of his actions and given him a leading position in relation to others. Now a compulsory stroll along the river starts to guide him and he has visions in which the soul of the river speaks to him and tells him about his future. Through his obsession, Dörffer's character is similar to Kallas' other characters: to the priest of Reigi and to the (forest) ranger Priidik (The Wolf's Bride), who also, in a compulsive manner, long for their (lost) lovers.

During the years in between the wars, the masculine ideal was constructed especially strongly around a norm of masculinity, in which selfcontrol and repudiation of desire played an essential part (Koivunen 2003, 214-220, see also Petersen 1998, 52-55). Kallas tests this ideal of hegemonic masculinity in her work and, through her performances of masculinity, she brings new understandings of the dominant imagery of masculinity coloured by militaristic and nationalistic ideologies (cf. Petersen 1998, 53-55). From the point of view of the masculine hero, Adam Dörffer's exaggerated masculinity reveals itself to merely be a ridiculous attempt, and through its emphasis on achieving, it also becomes a parodic imitation of masculinity. (Comp. Leppihalme 1999, 112-116.) Furthermore, it brings up the idea that perhaps men as well are strongly bound up with nature but have to deny this "feminine" aspect within them.

The "transformations" of Priidik in The Wolf's Bride and Adam Dörffer in "The Revenge of the Holy River" resemble one another. The actions of both are driven by obsession and both are unable, finally, to think about anything but their respective love objects. However, whereas Priidik's experience of rebirth requires that he first kill the wolf, defined here as feminine, Adam's rebirth is realised in death when he is violently drowned by the river which is associated with the feminine. As a male hero, Adam Dörffer makes a very interesting character: he is in the end the antithesis of the traditional male actor who is expected to gain victory by overcoming or destroying the obstacles in his way. Instead of triumphing over the "feminine", i.e., the river, he tries to become a part of that flowing and changing element that he had at first felt to be alien and unworthy. The character can be read as a new construction of the masculine subject, one which no longer feels the need to make a sharp distinction between self and other or to escape the feminine. He merges with it instead and his death can in this sense be interpreted as both a punishment and rebirth. This merging, however, also repeats the archetypal pattern in which nature is seen as the body of a nourishing, caring mother and as such it provides the male actor with a feeling of harmony and connectedness (cf. Soper 2000, 142).

At the time of his death, Dörffer is happy. He knows he will be allowed to unite with his beloved "maiden", who has him enchanted. This time, however, the unification will happen through conditions defined by others, since the master is tied by his hands and feet to the pole of the mill blockade. There, he lies helpless when the dam is broken and the waters flow over him. At the same time, the master has to witness the destruction of his own creation. It is possible to interpret the tying up of the master as a reference to Christ and the crucifixion, especially since, through his death, Dörffer redeems the people of Livonia. The good qualities of the river return after his death. 
Even though death is depicted in the novel as bliss, man's body is still made the object of disgrace:

Dörffer's battered and mutilated body sticks to the same trunk as the dead body of a dog he once threw in the river in order to humiliate it. After the depiction of the way in which Dörffer's disfigured body is lifted to the surface, and the sacred river once again flows freely, it is possible to read the novel as the writer's counter-text and comment on the denouement of the novel The Wolf's Bride, published two years earlier. The body of the master has become formless (matter) and faces the same disgrace as the female bodies in Kallas' 1920s trilogy. In light of this "The revenge of the Holy River" is formidable. Whereas the body of Aalo in The Wolf's Bride was burned twice as punishment for her border crossings, the punishment of the master, with his technical knowledge, can be seen as a metaphoric punishment and death of the kind of knowledge that has its foundation in the abuse of nature. Moreover, the feminine character in this story, the river, remains alive and runs free unlike in Kallas' Eros the Slayer trilogy where all the main female characters are killed in one way or another.

Dörffer's mutilated body remains visible in the river as a kind of reminder of the dark sides of the faith in technology and the abuse of nature. The parallel constructed between Adam's body and a dog is also central. In the short story, the master of knowledge is contrasted to nature and to an animal: culturally, the contrast between a human and a dog, in particular, has functioned as a sign of disdain and degradation. Drawing a parallel between man and dog produces the masculine subject though a similarly degrading definition of the difference that Western culture has, throughout the centuries, used to construct femininity.

Through this parallel, that which is characterised as feminine is, in $\mathrm{Ka}$ llas' work, formed as a metaphor of purity and power, whereas that which is characterised as masculine represents filth, impurity and repression. In this sense, the story illustrates the principles of early eco-feminism, in which the cultural elements traditionally coded as feminine are uncritically idealised (cf. Sturgeon 1997, 28-32.) Finally, the loss of knowledge and the impossibility of action, crystallised in the body of the dead dog, are also connected to the masculinity of "the Revenge of the Holy River". At the same time, both the masculine and the feminine subject are reorganised in the novel. Regardless of his degradation, Adam Dörffer is not necessarily a loser. On the contrary, it is possible to interpret his death as a miracle of rebirth. This interpretation is further reinforced by the metamorphosis into a new man that Adam experiences, in which new, "softer" characteristics finally make it possible for him to achieve a blissful end (beginning).

At the end of the short story the mill and dam Dörffer has built have collapsed and the river's benevolent, life-giving qualities have been restored. The deluge at the end of the short story can also be interpreted as a metaphor for rebirth and a new beginning. A flood, as with water in general, "cleanses" the earth and begins everything anew. At the same time the novel ends the way it began, i.e., with a Biblical allusion to the Apocalypse. The waiting for the Apocalypse in the Bible has, after all, been interpreted in contemporary theology as representing a longing for and expectation of the dawning of 
a new faith, the impetus to expose wrongs and the incentive to act more justly and towards creating a better world (Räisänen 1999, 56-57; cf. Buell 1995, 297-298). ${ }^{10}$ "The Revenge of the Holy River" rounds off Kallas' writing within the apocalyptical tradition in the 1920s and points towards the possibility for change: the short story pushes for a change in human life and action which would make living in harmony with nature at all possible. At the same time a description of a new gender order emerges from the story, which is not primarily characterised by and dominated by hierarchical oppositions. This new gender order would enable a new "natural order" along with it.

\section{Notes}

1. This article is based on my earlier article published in 2008 in the collection Ä̈nekäs kevät. Ekokriittinen kirjallisuudentutkimus. [Noisy Spring. The Ecocriticism in Literature Studies.] Toni Lahtinen and Markku Lehtimäki (eds.) Helsinki: Finnish Literature Society.

2. The short story has not been translated. I want to thank professor Paavo Castrén who kindly translated the quotations used in this article.

3. Vieras veri [Alien Blood] (1921), Barbara von Tisenhusen (1923), Reigin pappi [The Rector of Reigi] (1926), Sudenmorsian [The Wolf's Bride] (1928) and Pyhan joen kosto [The Revenge of the Holy River] (1930).

4. The pamphlet has been republished in 2007 and in her foreword, Helena ForsåsScott, considers it to be a pioneering text of ecofeminist thought in Europe, as does Katarina Leppänen in her thesis about Wägner (2007, 5-26).

5. Kallas' novels and short stories are always situated and distanced in Estonian history, usually in the $16^{\text {th }}$ and $17^{\text {th }}$ centuries.

6. [Tapahtui Anno 1640, että mestari Adam Dörffer, myllynrakentaja Arnstadtin kaupungista Saksanmaalta, sai herra Hans Ohmilta kiireellisen kutsun saapua Liivinmaalle rakentamaan vesimyllyä Võhandun jokeen Sõmerpalun moision kohdalle. Vaan täten saivat alkunsa kaikki ne erinomaiset ja ennenkuulumattomat asiat, jotka ihmisten mieliä suurella kiivaudella kiihoittivat lähes kaksi kokonaista ajastaikaa ja lopulta veivät hävityksen kauhistukseen, ihmishenkien hukkaan, ankaraan rangaistukseen ja isoon parkuun.] Reference is to the collection Imant ja hänen äitinsä. Pyhän joen kosto. [Imant and his Mother. The Revenge of the Holy River] referred to as $P J K$.

7. [Ja mestari Adam Dörffer aamuisin padon ohitse ratsastaessansa vahingonilolla ajatteli Võhandun vastahakoisia vesiä, jotka padon piti paisuttaman, niin että ne kuuliaisina hänen tahtoansa ja myllyä palvelisivat, viljan jauhaisivat ja sahaa käyttäisivät. Niin tämä ajatus täytti hänen henkensä hekkumalla, niinkuin olisi ollut kyseessä kaunis ja oikullinen sekä ylön vaikiasti valloitettava vaimonpuoli, ja askarrutti niin kokonansa hänen aikansa, että hän vastoin tapojansa unhoitti kaikki lemmenseikat eikä ottanut itsellensä mielenrohkaisijatarta, kuten muuten oli aina tehnyt kohta ensimmäisen viikon kuluessa uudella työmaalla.]

8. [Mutta tämä oli totisesti lopun alku, ja Suuren Nälän varjo lankesi yli maan niinkuin varjo vaeltajan edelle, joka tuleva on. Sillä tämä erinomainen ja outo sää, joka oli vastoin kaikkea luonnonjärjestystä, niinkuin olisivat itse tähdet ja Elementit kapinan tehneet, ulottui Lätinmaalle ja Suomeen saakka sekä vielä ylitse Pihkovan ynnä Aunuksenkin rajojen. Ja näytti todeksi käyvän, mitä Jumala Jeremian, sen väkevän profeetan suulla on julkijulistanut: “ihmisten ruumiit pitää niin kuin loka 
maan päällä kaatuman, ja niinkuin jalalliset jäävät elomiehen perään, jossa ei ole ylösottajata".]

9. [...niin oli Adam Dörffer tästä huomenhetkestä muuttunut mies.]

10. Lawrence Buell (1995) points out the way in which apocalypse as a literary trope conveys a number of different feelings of crisis (mainly in an American context). Rather than being associated solely with the environment, these crises could include those caused, for example, by strikes, class or race struggles or the modernist revolution.

\section{References}

\section{Research Objects}

Kallas, Aino 1921: Vieras veri. Rakkauskertomuksia. [Strange Blood. Love Stories.] Helsinki: Otava.

Kallas, Aino 1928: Sudenmorsian. Hiidenmaalainen tarina. [The Wolf's Bride. A Tale from Hiiumaa.] Helsinki: Otava.

Kallas, Aino 1930: Imant ja hänen äitinsä. Pyhän joen kosto. [Imant and his Mother. The Revenge of the Holy River.] Helsinki: Otava. (PJK)

\section{Research Literature}

Buell, Lawrence 1995: The Environmental Imagination. Thoreau, Nature Writing and the Formations of American Culture. London: Harvard University Press.

Buell, Lawrence 2005: The Future of Environmental Criticism. Environmental Crisis and Literary Imagination. London: Blackwell Publishing Ltd.

Felski, Rita 1995: The Gender of Modernity. Cambridge, Massachusetts and London, England: Harvard University Press.

Garrard, Greg 2004: Ecocriticism. London: Routledge.

Haila, Yrjö \& Lähde, Ville 2003: Luonnon poliittisuus: Mikä on uutta? [The Political in Nature. What is New?] In: Yrjö Haila ja Ville Lähde (eds.), Luonnon politiikka. [The Politics of Nature.] Tampere: Vastapaino.

Haila, Yrjö 1999: Luonto ja luonnon tuho. [The Nature and its Destruction.] In: Tuomas. M. S. Lehtonen (ed.), Lopun leikit. Uskon, historian ja tieteen eskatologiat. [The Games of The End. The Escatologies of Religion, History and Science.] Helsinki: Gaudeamus.

Häggman, Kai 2001: Piispankadulta Bulevardille. Werner Söderström Osakeyhtiö 18781939 [From Bishop Street to Boulevard. Werner Söderström's Limited Company 1878-1939.] Helsinki: WSOY.

Keller, Evelyn Fox 1988: Tieteen sisarpuoli: pohdintoja sukupuolesta ja tieteestä. [Reflections on Gender and Science.] Original 1985. Translated by Pia Sivenius. Tampere: Vastapaino.

Koivunen, Anu 2003: Performative Histories, Foundational Fictions. Gender and Sexuality in Niskavuori Films. Studia Fennica: Historica. Helsinki: Suomalaisen Kirjallisuuden Seura.

Lahtinen, Toni 2005: "Enää ei tule kesää" - Ympäristöherätys Timo K. Mukan romaanis- 
sa "Ja kesän heinä kuolee". Avain. Kirjallisuudentutkimuksen aikakauslehti 1:4. [There will no longer be summer" - The environment awakening in Timo K. Mukka’s novel "And the hay of summer will die". The Key. A Journal of Literature Studies.]

Lehtonen, Mikko 1994: Kyklooppi ja kojootti. Subjekti 1600-1900-lukujen kulttuuri-ja kirjallisuusteorioissa. [A Cyclops and a Coyote. The Subject in Culture and Literature Theories between 1600-1900.] Tampere: Vastapaino.

Leppihalme, Ilmari 1999: Niin on jos siltä näyttää: Runebergin kuningas, drag ja kansakunta. [So it is, if it seems so: Runeberg's king, drag and nation.] In: Outi Alanko ja Kuisma Korhonen (eds.), Subliimi, groteski, ironia. Kirjallisuudentutkijain Seuran vuosikirja 52. [Sublime, Grotesque, Irony. The Yearbook of the Literature Studies Society.] Helsinki: Suomalaisen Kirjallisuuden Seura.

Leppänen, Katarina 2005: Rethinking Civilisation in a European Feminist Context. History, Nature, Women in Elin Wägner's Väckarklocka. Gothenburg Studies in the History of Science and Ideas 18. Acta Universitatis Gothoburgensis.

Lloyd, Genevieve 2000: Miehinen järki. "Mies" ja "nainen" länsimaisessa filosofiassa. [The Man of Reason. "Male" and "Female" in Western Philosophy.] Original 1984. Translated by Marjo Kylmänen. Tampere: Vastapaino.

Lyytikäinen, Pirjo 1999: Tuhoutukoon maailma. Lopun aikojen kirjallisuutta. In: Tuomas M. S. Lehtonen (ed.), Lopun leikit. Uskon, historian ja tieteen eskatologiat. [The Games of The End. The Escatologies of religion, history and science.] Helsinki: Gaudeamus.

Melkas, Kukku 2006: Historia, halu ja tiedon käärme Aino Kallaksen tuotannossa. [History, Desire and the Serpent of Knowledge in the Works of Aino Kallas.] Helsinki: Suomalaisen Kirjallisuuden Seura.

Mellor, Mary 1997: Feminism and Ecology. Cambridge and Oxford: Polity Press.

Merchant, Carolyn \& Peterson, Abby 1996: Peace with the Earth: Women and the Swedish Environment. In: Carolyn Merchant (ed.), Earth Care: Women and the Environment. London: Routledge.

Niinisalo, Suvi 2006: Vedenneitojen lähteillä. [In the Springs of the Mermaids.] Jyväskylä: Atenakustannus

Paqvalén, Rita 2007: Kampen om Eros. Om Kön och Kärlek i Pahlensviten. Meddelanden från avdelningen för nordisk litteratur nr 16. Helsinki. [A Struggle of Eros. About Gender and Love in Pahlensviten.] Department of Skandinavian Literature no 16. The University of Helsinki.

Petersen, Alan 1998: Unmasking the Masculine. 'Men' and 'Identity' in a Sceptical Age. London: Sage Publications.

Plumwood, Val 1993: Feminism and the Mastery of Nature. London: Routledge.

Räisänen, Heikki 1999: Raamattu ja lopunodotus. In: Tuomas M. S. Lehtonen (ed.), Lopun leikit. Uskon, historian ja tieteen eskatologiat. [The Games of The End. The Escatologies of religion, history and science.] Helsinki: Gaudeamus.

Soper, Kate 2000: What is Nature? In Lawrence Coupe (ed.), The Green Studies Reader: from Romanticism to Ecocriticism. New York and London: Routldege.

Sturgeon, Nöel 1997: Ecofeminist Natures. New York and London: Routledge.

Suutala, Maria 2001: Kesytetty nainen. Seksuaalisuus ja luontosuhde länsimaisessa ajattelussa. [The Tamed Woman. Sexuality and the Relationship to Nature in Western Thought.] Helsinki: Helsinki University Press.

Williams, Raymond 2003: Luontokäsitykset [1980] Translated by Mikko Lehtonen. In: Yrjö Haila ja Ville Lähde (eds.), Luonnon politiikka. [The Politics of Nature.] Tampere: Vastapaino. 


\section{Crossing Modernity's Master Discourses}





\title{
Decadent Modernism and the Imprint of Taine in Aino Kallas'
}

\author{
Young Estonia: Portraits and Trajectories
}

Aino Kallas' significance for Estonian culture is not limited to the frequent Estonian topoi in her literary works, nor to her contribution to the intensification of cultural ties between Estonia and Finland. Her reviews and essays on Estonian literature and culture, which like her literary works were originally published in Finnish, are of enduring importance. ${ }^{1}$ While their focal point is the analysis of Estonian texts in their immediate and historical contexts, Finnish literature and culture constitute the implicit background of these pieces, as well as a source for analogies and contrasts. The topic of this article is Kallas' essay collection Nuori Viro. Muotokuvia ja suuntaviivoja [Young Estonia. Portraits and Trajectories] (1918), specifically its concern with the experience of decadent modernism. ${ }^{2}$ The essays focus on the Young Estonia movement and its component authors, who individually and collectively made a powerful contribution to the modernization of Estonian literature and culture at the beginning of the $20^{\text {th }}$ century. Though research has been done on the genesis of Kallas' essay collection, her interpersonal relationships with members of Young Estonia, and aspects of the conceptual framework of the collection that Kallas ostensibly borrowed from Estonian writers inside and on the periphery of the Young Estonia group (cf. Laitinen 1997, 104-107; 156-159; Andresen 1983, 195-210; Olesk 2003, 561-570) scant attention has been paid to the implications of Kallas' treatment of the experience of modernity. The influence on Kallas' literary thinking and her approach to Young Estonia of $\mathrm{H}$. Taine's literary-historical ideas, pervasive in Europe at the time, has also received only passing notice. ${ }^{3}$ Taine's imprint on Kallas' explanations of Young Estonia's place in cultural history and discourse, particularly his insistence on contextualizing literary texts in the cultural "moment" of their genesis, shall be my second focus in this article.

In a broader sense, Estonian cultural figures may have been conscious mediators of discourses of modernity, which they themselves did not generate; the generative voices were located in European metropolitan centres, from which ideas percolated to the periphery, the European provinces, where they were "overheard" and selectively amplified. As Kallas shows in 
her essays, the deliberate adoption of modernity by the Young Estonians was a complex accommodation to a local environment that had both a temporal and geographical specificity, and that, in Taine's terms, gave rise to a palpable or discernible "Estonian psyche".

Kallas consciously positioned herself as a writer of modernity. However, studies that have explored her relationship with modernity have heretofore omitted her Young Estonia essays from consideration, with the sole exception of her essay on J. Randvere's "Ruth". ${ }^{4}$ In Kallas' essay collection on Young Estonia, reciprocal influences between modern ways of speaking, thinking, behaving, and perceiving give rise to an unusual synthesis, which bears Kallas' unique signature, but also evokes a more general European experience of modernity. This multiply ambivalent modernity spans many contradictions: an Enlightenment vector aligned with positivism and belief in progress, and a vision of regression, fed in the fin de siecle by discourses of decadence and/or degeneration. ${ }^{5}$ Kallas' discussion of Young Estonia in relation to decadence and/or degeneration thematizes several aspects of the second term of this polarity: a hereditary lack of psychic vitality, reverse natural selection, and an overheated, accelerated tempo of modernization accompanied by forms of moral, physical, intellectual, and psychic decline. All of these specific features are undergirded by a decadent conception of culture. As for the majority of her contemporaries, Kallas' relation to the condition of modernity is defined by a heightened perception of time. ${ }^{6}$ As I will show in the last section of this article, it is plausible that Kallas' temporalized perception of modernity has been somewhat shaped by Taine's philosophy of history, where the thematization of temporal change is conceptually central.

\section{On the genesis of Young Estonia}

As the manuscript for her essay collection was coming to fruition, Aino Kallas wrote in her diary (24 April 1918): "I have never struggled so hard with a text as I have with my Estonian essays; I have been infuriated and frustrated. ... And so I have to chew on them for yet a third year. Maybe it is because the essay is not my genre, or maybe it is because of all the beautiful and difficult experiences I have lived my way through over the last few years" (Kallas 1954, 148). 7 The feeling of being beset by obstacles and needing to overcome herself is connected most broadly with Kallas' ambition to identify herself above all as a creative writer. This is indicated by her disclaimer, "the essay is not my genre" as well as in several other diary entries which describe the writing of an article as a surrogate activity masking creative crisis (cf. e.g., 19 February 1912; 29 March 1915, Kallas 1953, 265, 346-347). The intellectual tension and frustration Kallas feels and the "difficult birth" of the Young Estonia book also point to her life situation at the time: the completion of the essay collection fell into a period charged with strong emotions. In addition to falling in love with Latvian artist Janis Rozentāls in the summer of 1916, Kallas' emotional and intellectual world in 1917-1918 was filled by the renowned Finnish poet and journalist Eino Leino. The "beautiful and 
difficult things" mentioned in the diary entry point both to her relationship with Rozentāls and the Kallas-Leino love affair.

The laborious process of completing the essay collection was further complicated because Kallas had too close a personal connection with the topic of her research. During her Tartu period, through a perceived affinity with the modern ideology espoused by the Young Estonia movement, she identified herself as a modernist. On November $11^{\text {th }}, 1912$, she writes in her diary, "I have finally found myself and my own element" (Kallas 1953, 282). ${ }^{8}$ This self-identification assured her a place on the map of Estonian literary modernism: many of Kallas' critical reviews and studies (as well as her literary texts) were published in Young Estonia's albums and magazines. Kallas also formed warm, personal friendships with several members of the Young Estonia movement. Despite the above-mentioned psychological difficulties, Kallas' study of Young Estonia was well received. ${ }^{9}$ Kallas' liminal position may have offered her a more objective point of view than that of Young Estonia's insiders (cf. Olesk, this collection; Laitinen 1997). Compared to the insiderly texts that summarized the first 10 years of Young Estonia's activities, ${ }^{10}$ Aino Kallas' essay collection is notable for its thoroughgoing positivist synthesis and detailed background knowledge of the era.

Kallas' book on Young Estonia consists of seven different essays, each divided into three to six sections. The introductory article, entitled "Young Estonia", the longest in the collection, gives an overview of the movement, focusing on Young Estonia's modern ideology (including language renewal), its genesis in the context of Estonia's socio-cultural and political development in the decades spanning the fin de siècle, and its reception. The remaining six essays are individual portraits of writers who were more or less formally connected with the movement: poets Gustav Suits and Villem Grünthal-Ridala, and prose writers Jaan Oks, A. H. Tammsaare, and Friedebert Tuglas. ${ }^{11}$ In all of the portraits Kallas formulates generalizations based on a positivist model of life and works (Leben und Werk) drawing comparisons within each oeuvre between works written in different creative periods. However, stressing the uniqueness of each author's works was not Kallas' primary goal. Instead, she was interested in broader issues, such as the extent to which the works of these specific authors were expressions of Estonian nationality and race. According to Kallas, a writer's works are outgrowths of the surrounding environment and the spirit of the age. It is no accident that these circumstances coincide with what $\mathrm{H}$. Taine deemed the defining criteria for good art. As I argue below, Taine's literary theory significantly shaped Aino Kallas' composition, articulation and interpretation of her account of Young Estonia.

\section{The genre of the literary portrait in fin de siècle Europe}

Why did Kallas choose the genre of the portrait as the embodiment of her theoretical understanding of literature? The genre of the so-called "creative portrait" was in vogue in Scandinavia at the end of the $19^{\text {th }}$ century and the 
beginning of the $20^{\text {th }}$, as modelled by Oskar Levertine, Anna-Maria Tallgren, Georg Brandes, and Laura Marholm; Kallas' conversancy with these works can be shown by a wealth of references to them in her own writing. Her familiarity with French traditions of literary portraiture - as inaugurated by Charles Augustin Sainte-Beuve (1804-1864), who later went on to influence the views of $\mathrm{H}$. Taine - is also unquestioned, as shown by the large number of quoted sources. However, Kallas' Young Estonia collection takes a pessimistic tone, pointing to further layers of French influence, notably the influential thinker Paul Bourget (1852-1935). Bourget also carried a Taineian imprint, visible in the conceptual structure and method of his essays, which were psychological portraits, mostly of French writers and theoreticians such as Charles Baudelaire, Ernest Renan, Gustave Flaubert, and Hippolyte Taine, and which taken together effectively provide a summa of the spirit of the fin de siècle. Each writer's portrait is coded by one tendency of cultural pessimism. Baudelaire is thus aligned with decadence in the narrower sense, Renan with dilettantism, Stendhal with cosmopolitanism, Taine with pessimism and scepticism, Flaubert with exoticism, Amiel, Baudelaire, and Stendhal with the spirit of analysis. In the course of Bourget's analyses, these features intersect and overlap, making finer distinctions difficult. ${ }^{12}$

One can observe that the pessimistic view of life that dominates Bourget's literary portraits in the collection entails a variety of key words: decadence, melancholia, dilettantism, the analytic spirit, weakness of will, and cosmopolitanism. Decadence holds a particular place for Bourget, and he uses the term both in its broader and narrower meanings. On the one hand, decadence is an objective correlative of cultural pessimism; on the other - as in the dominant attributed to Baudelaire - it is one of its specific expressions. On a more theoretical level, Bourget understands decadence to be a certain stage of social-cultural development, and its spirit is quintessentially expressed by creative artists, highly developed individuals whose refinement locates them at the zenith of civilization. While in this sense Bourget's concept of decadence may seem totalizing, there are scattered references indicating that he uses the term "decadent" as a more general synonym for modernity and modernism. In this light, the "tendencies of the age" can all be traced to the results of a new epistemology. In his essay on Taine, Bourget writes:

We are living in an age of the collapse of religion and metaphysics ... we no longer have a general credo the way 17 th century people did ... we have also lost that force of negation that was the 18th century's oppositional credo. All those who tied themselves directly or indirectly to the struggle led by Voltaire could at least be certain about the fact that they were fighting against error ... In today's age of critique there is no longer any such certainty... We have added so many new viewpoints - having patiently studied the origin of all doctrines... and we have come to think that a kernel of truth lies hidden even in the most contradictory hypotheses about the nature of man and the world. From this comes a skepticism that is without analogy in the history of ideas. The pain of doubting even our doubt brings along with it a host of illnesses that we are all familiar 
with; a lack of willpower, sophistical compromises with our conscience, and a dilettantism that looks at things from the sidelines and does not participate. (Bourget 1883, 198-199.) ${ }^{13}$

In this quotation Bourget focuses on the process of secularization and the emergence of a massive amount of new knowledge, resulting in the relativization of truth. The outcome of these processes is scepticism, one of the primary characteristics of modern culture. It is clear that Bourget does not favour these pessimistic tendencies. While decadent culture may be an admirable expression of a high level of civilization, there is a high price to be paid. A hypertrophic socio-cultural context, overcharged with knowledge, overly rationalized and technologized, ultimately leads to a distantiation from the natural state. By extension, decadence becomes the umbrella signifier for artificiality, and a loss of unity, wholeness, and organization. The polysemy of Bourget's concept of decadence indicates that by the time his essays were published in the last decade of the 19th century, decadence had become loaded with so many diverse meanings that it can with all justification be spoken of as a discourse (cf Kafiz 2004). The most famous "decadent" thinker of the era is doubtless Friedrich Nietzsche, and it should not be forgotten that his ideas about decadence were strongly coloured by Bourget. Nietzsche extended Bourget's concept of decadence toward an even more totalizing range of meanings (Stoupy 1996), and states often that decadence is an unavoidable process observable in all cultural life.

At the end of the 19th century, the discourse of decadence and/or degeneration had spread throughout Europe. It found expression in Estonia in the mature period of the Young Estonia movement (1905-1915) at the end of the first decade of the $20^{\text {th }}$ century. Though it might be argued that the rhetoric of decadence (and/or cultural decline) had permeated Estonian cultural discourse more broadly by that time, the Young Estonians were the main target for negative labels like "decadents" and "degenerates". Kallas' treatment of Young Estonia also articulates a decadent concept of culture as a filter for interpreting a wide range of specific phenomena. Almost all the Young Estonia essays concerned with the subject (except for the essay on Ridala) indicate that Kallas regards her age as one of decline and "sickness" (Kallas 1918, 229). To designate the symptoms of this disease, she uses conceptual vocabulary familiar from the works of artists and writers of decadence: scepticism, cultural fatigue, self-analysis, cerebral culture, the cerebral individual, egoism, infertility, neurosis, eroticism. ${ }^{14}$ Kallas' analysis of this predicament in Estonian culture has a fine-tuned sense of paradox. What she perceives and labels as "decadent" (or degenerate) is not just the old European tradition, which had reached its ultimate degree of refined civilization, and had nowhere to go but decline; Estonian culture is also decadent, though still in its youth, and in the formative stages of constituting its cultural traditions. Because old Europe is the object of Young Estonia's desire, "young" Estonian culture is included by implication, and doomed to be "old" before its time. This insightful deduction on Kallas' part can be explained by her perception of accelerated time, and it is this temporalization of her own experience which gives rise to terminology such as the tempo 
of progress, the educational leap, quickness, and rupture that she applies to the Estonian socio-cultural situation.

Kallas illustrates accelerated change in Estonian society with a striking example that juxtaposes two historical events that took place in the heart of Tallinn within an interval of 50 years. In the middle of the 19th century, Estonian serfs who had come to demand an end to slavery were brutally beaten in the Tallinn market square. Fifty years later, in 1913, not far from that very location, the grand opening of the theatre and concert hall "Estonia" was celebrated. According to Kallas, it is theoretically possible that an Estonian serf, flogged there fifty years earlier, could have been sitting in the audience "clothed in silk and velvet and a fashionable coat and tails, along with his children and grandchildren... listening to the words of the Danish prince Hamlet spoken in his own mother tongue"15 (Kallas 1918, 12). In a short time Estonia had undergone a complete socio-cultural transformation, from an agrarian society founded on labour-slavery to a modern democratic society. Yet though this example naturally applauds the onward march of progress, Kallas mostly writes about the negative consequences of this rapid developmental leap. The symptoms of the "sick age" (Kallas 1921, 170) and the Bourgetian tendencies of the pessimistic spirit are attributable to an inability to keep emotional pace with rapid social change. Kallas goes even further in her critique of modernity: "There is doubtless something fateful in the particular speed of this tempo of intellectual development"16 (Kallas 1918, 56), she writes. The image of "educational death-leap or salto mortale" (Kallas 1918, 185) epitomizes this particular fatefulness: in all the expressions of Estonian educational life, one can see the scars of an extraordinary cultural acceleration posing a serious threat to the balanced development of the social organism (Kallas 1918, 11-15). As will be explained in more detail below, the repeated allusions to these "scars of development" have affinities with $\mathrm{H}$. Taine's accounts of cultural processes.

\section{Kallas and Taine}

In her study of Young Estonia Kallas cites mostly Estonian theorists and writers, ${ }^{17}$ though from time to time she introduces a European or Scandinavian name, either in a comparative context or in cases where she seems to require an authoritative commentator to support her view of a phenomenon. For Kallas the crucial European names are: George Brandes, Hermann Bahr, Paul Verlaine, Larin Kyösti, Eino Leino, Veikko Antero Koskenniemi, Dante Gabriel Rossetti, Henri-Frederic Amiel, Théophile Gautier, Bertel Gripenberg, August Strindberg, Arthur Schnitzler, Otto Weininger, Paul Möbius, Juhani Aho, Hippolyte Taine, Joris-Karl Huysmans, Edgar Allan Poe, Anatole France, Maurice Maeterlinck. Clearly the range of influence (positive or negative) of these cultural figures on Kallas' writings (including the Young Estonian essays) varies. According to Sirje Olesk, Kallas' account of Young Estonia may have been inspired by the series of articles entitled Suomalaisia kirjailijoita [Finnish Writers] published from 1909 to 1916 by Finnish poet and critic Eino Leino, who was the focus of Kal- 
las' romantic attention during this period (Olesk 2003, 567). Indeed, the introduction to Leino's series of articles summarizes the core concepts of "creative portraiture" in vogue at the time, Kallas often based her essays on similar principles: literary works are influenced by three great factors: "the spirit of the age, the spirit of the nation and the specific personality of the literary figure" ${ }^{18}$ (Leino 1909, 8).

These three factors can be directly traced to Hippolyte Taine (1828-1893) and his epigones. ${ }^{19}$ Kallas' first reference to reading Taine is in a diary entry dated August 11 ${ }^{\text {th }}$ 1914: "I spent the morning working, reading Taine's art history, lying in the hammock with Hillar beside me, pondering the theory of milieux"20 (Kallas 1994, 266). At the end of that year, on 21 December 1914, she notes, "I am reading Taine's philosophy of art" ${ }^{21}$ (Kallas 1955, 313). Thus Kallas confirms that she was reading Taine's Philosophy of Art just before assembling the raw materials and drawing up the conceptual framework for her "Young Estonia" pieces. Traces of Taine's conceptual vocabulary can even be found much earlier, in Kallas' book reviews, which should be regarded as preparatory work for the Young Estonia collection. The French word "milieu" appears in several places in her June 30 $0^{\text {th }}, 1909$ review of A. H. Tammsaare's university novellas "Young Souls" (Kallas 1909a) in the newspaper Postimees. A passage from the review of Young Estonia's third album, where Kallas comments on J. Aavik's "Ruth" refers to Taine's frequent use of biological metaphor: "What is peculiar is this attempt to graft the refined shoot of high culture onto the root of Estonia's fully peasant culture" (Kallas 1909b). ${ }^{22}$ Another diary entry, from August $25^{\text {th }}, 1910$, also calls Taine's ideas to mind: "On the third I went to the doctor about my eyes; he thought he noticed signs of trachoma in the left one. This is Saaremaa's gift to me, and it seems I have to bear even this purely Estonian illness, just as I have lived my way through Estonian fatigue. After all, a person is the slave of his milieu..." (Kallas 1953, 200). ${ }^{23}$ Other passages in the diary from around the same time also have a Taineian ring, where Kallas identifies herself with a transitional figure of the age, or with the social type of the upstart [tõusik, nousukas]. ${ }^{24}$ For example, on December $13^{\text {th }}, 1909$ she writes: "The writer whose success comes late, as the fruit of arduous labour, is like the upstart, ashamed of his poverty and of the poor quality of his works" ${ }^{25}$ (Kallas 1953, 180).

However, Kallas' specific connections with Taine at the end of the first decade of the $20^{\text {th }}$ century are rather difficult to pin down, and may also have been mediated more indirectly. Several European thinkers, including P. Bourget, E. Zola, G. Brandes (the latter much admired by both Kallas and the Young Estonians) were advancing and disseminating Taine's ideas. Indeed, the rediscovery of Taine at the beginning of the $20^{\text {th }}$ century was largely Brandes' doing. ${ }^{26}$ Kallas' interest in Taine could also have been intensified by the publication of the Finnish translation of Taine's Philosophie de l'Art (1865-1869) in 1915 (Taiteen filosofia). Not insignificantly, the translator, L. Onerva, was one of the most powerful women modernist writers of the beginning of the $20^{\text {th }}$ century in Finland, who held extensive discussions of Taine's theories and popularized his ideas both in her essays and her literary texts. ${ }^{27}$ 
In sum, Taineian arguments, concepts, and rhetoric in Kallas' account of Young Estonia are too significant for the researcher to have any doubts about his direct and indirect influence on the project. A quotation from Taine, located in the concluding portrait of F. Tuglas, sums up the founding structural principle of the essay collection (165-166). The terminology of Kallas' portraits can be traced to Taine (atmosphere, psyche, milieu, environment, breed, organism, temperament type, basic instinct), not to mention the discussions of "type of the age" and "sick age" (170).

\section{Taine's theory of the three influences}

Taine combines the core ideas of romanticism and positivism, adjusting them to fit the study of art (including literature). He considers it to be the task of science to study the spirit and its activities objectively, through the examination of small events or episodes. For literary study this means knowledge of the circumstances that affected and shaped the writer's soul. These influences are given a threefold conceptual structure: race (le race), the epoch (le moment) and the environment (le milieu). Taine presents this so-called "theory of the three influences" in its first and most concentrated form in the book Histoire de la littérature anglaise [The History of English Literature 1863], a voluminous work divided into several parts. The second sentence of the introduction clearly states the importance of context for study of the literary work: "A work of literature is not a mere play of imagination, the isolated caprice of a heated brain, but a copy of the surrounding manners and a sign of a state of mind" (Taine 1883 vol 1, 1).

One of Taine's presuppositions is that all culture, literature included, is interwoven with the context in which it occurs. The building blocks of context are listed more specifically in the introduction to Philosophy of Art: the writer's own entire oeuvre, the oeuvre of his contemporaries, and finally the environment or surrounding milieu and the mentality of the age, or moment it contains (Taine $1875,9-13 ; 1915,4-7) .{ }^{28}$ Race is defined as both a biological and a cultural heritage, a fixed, universal, and unchanging foundation. Milieu and moment, however, are local factors that are more subject to change. It might be said that race determines the essence, manifested internally, and this is then modified by milieu and moment. Milieu is manifested externally, in physical circumstances (climate, landscape), or social circumstances (revolution, wars, famines).

Problems arise in the application of this conceptual framework because Taine is not very consistent in his thinking (cf Brown 1997). Physical determinants of milieu such as climate and landscape can be so enduring as to resemble race. Because their influence shifts with time, social circumstances included in the category of milieu can sometimes more productively be connected with the third category, moment. By moment, Taine seems primarily to refer to the atmosphere or mentality characteristic of a specific time period, which can spring up in the individual as active, spontaneous energy, and in turn reshape the collective spirit (or spirit of the race). As is clearly seen in the introduction to History of English Literature, Taine often 
defines moment as a developmental level or stage using the organic metaphor of "buds, flowers, fruits, seed-vessels", amounting to a general law of cyclical development. Thus a moment (or epoch) can be spoken of in terms of birth, maturation, and decline, an accumulating or diminishing civilizational energy (Taine 1883, 16-22; cf. Brown 1997). In Philosophy of Art classical structures standardize the model so that fullness manifests itself in a harmonious middle: "That is the moment when an art flourishes... This moment is found in Greece in the time of Sophocles" (Taine 1875, $330 ; 1915,528)$.

It is crucial not to lose sight of the fact that Taine never makes the claim that the three influencing factors illuminate all the dimensions of a work of art. The writer is not merely the product of race, the times, and the environment, and thus it would be false to call Taine a determinist. It should be kept in mind that he also partakes of the romantic treatment of the writer as an extraordinary individual, whose works of art come to birth only through a creative personality and individualized perception (cf. Koskela, Rojola 1997, 16-17; cf. Brown 1997).

Having outlined the operation of the three influences in Taine's own works, we can more legibly decipher its traces in Kallas' portraiture and the literary history of Young Estonia. In her literary portraits Aino Kallas also emphasizes the specific individuality of each author. For almost every writer she portrays, she seeks a marker of individuality, a specific expression, word and/or nuance or colour, though she does not always differentiate these from the psychology of nation and/or race. For example the poetry of Gustav Suits is characterized by controlled power and masculinity (Kallas $1918,82)$; Ridala's temperament is marked by clarity and emphasis; Oks is "truly decadent, in body and spirit" ${ }^{29}$ (Kallas 1918, 147); Tammsaare's basic colour is gray, and his main characteristic is his scepticism (Kallas 1918, 173); J. Aavik, the author of "Ruth", is the preacher of aesthetic individualism (Kallas 1918, 213). Tuglas is the only writer whom Kallas refuses to subject to a category; he represents a multifaceted personality capable of variegated development (Kallas 1921, 224). More significantly, in the larger structure of her argument, Kallas connects the markers of individuality with features that transcend the individual - in Taine's terms with race, milieu, and moment.

\section{Young Estonia as the expression of the Estonian psyche}

As Kai Laitinen indicates in his monograph, Aino Kallas' pursuit of the typically Estonian in her Young Estonia essays is in accordance with the demands of her era (Laitinen 1997, 158). However, Kallas' interest in questions of race is also oppositional. The vocabulary of race provides her with the rhetorical ground on which to contest reproaches that rained down on the Young Estonians from right and left, ranging from "insufficient nationalism", borrowing of pernicious foreign ideas, and the cult of individualism and style - culminating in the accusation of decadence and degeneration. At times the strenuousness with which Kallas argues the case of Young Es- 
tonians' national character leaves the impression that she is also trying to convince herself:

It may seem hard to grasp that a movement can be born suddenly without precursors or visible preconditions, and that it takes a trajectory aimed at high culture and refined form, while making no use whatsoever of the peasant traditions of Estonia. The watchwords of this movement Europeanness, individualism, aestheticism - were so alien and isolated amidst the first generation of a society of upstarts. There seems to be an unblinking readiness to believe that the intellectual heritage of this young literary generation has been... taken over by direct transfer from larger and more developed cultures and completely disconnected from its environment and the recent educational past - This is how the Young Estonia movement shows itself at first glance. (Kallas 1918, 8-9.) ${ }^{30}$

What Kallas means by the society of first-generation upstarts, who lack connection with their own recent educational history, will be discussed in more detail below. For now, let me emphasize the congruence between the conclusion Kallas draws in this introductory essay and the arguments in the portrait pieces of individual authors. To avoid what she perceives as the "exaggeration" that the development of Young Estonia is somehow "rootless" (Kallas 1918, 8-9), Kallas demonstrates how the literary oeuvre of the Young Estonians is deeply and integrally connected with the milieu and spirit of their age, and with a national psychology moulded by these influences. Conversely, in her discussion of individual authors and their works, she seeks to foreground those expressions of the spirit that transcend the times, or that extend to the deeper layers of national characteristics and to the level of race.

An illuminating passage in Kallas' essay on Friedebert Tuglas illustrates her use of Taine's analytical instruments:

Taine is right, no doubt: every talented writer mirrors the characteristics of the race, even without wishing to. In rare cases he may even be the synthesis of all those different attributes of which the psyche of his race and his people are composed. More frequently the racial heritage given to each varies, and each reflects only a fraction of the great shared capital of the race. This racial belonging may often be almost unconscious, and does not necessarily correspond with what we have become accustomed to calling the "ethnic" treatment of literature. In world literature of writers there are plenty of examples of writers whose choice of subject matter is totally international, while in the deeper sense they are translators of their race. (Kallas 1918, 222-223.).

The placement of this explicit reference to Taine at the end of her essay collection might indicate that for Kallas, Tuglas corresponded most closely to Taine's ideal of the gifted writer - as the synthesizer of the different attributes of the race. While this gesture may perhaps also suggest the mediation of Taine's influence on Kallas through Tuglas, the specific Taine reference here has wide implications for the structure of Kallas' essay collection. Almost all of the authors she portrays represent for her some essential aspect characteristic of Estonians. In the introductory essay she writes: 
....all these ideals, all these sparks from the great suns of world metropolises are here refracted through a very particular Estonian prism. They have been coloured by the Estonian temperament. They have received a nuance, a personal hue from that same Estonian psyche, which can be felt in Suits' bog-poetry, Ridala's island landscapes, Jaan Oks' desperate sarcasm, and the ghostly feeling of Tuglas' novellas. The whole Young Estonia movement, with its false devices, misfirings, and exaggerations, is an expression of that ever more clearly crystallizing Estonian psyche, which despite all external pressures and internal chaos moves toward clarity and crystallization. (Kallas 1918, 63-64.) ${ }^{32}$

Interestingly and certainly not accidentally, Kallas leaves two writers, A. H. Tammsaare and J. Aavik ("Ruth"), without an explicit link to Estonian racial attributes. While Kallas may be attempting to convince the reader of the Young Estonians' "racial purity" in Taine's sense, the work of Tammsaare, Aavik, and to some extent Tuglas as well, exemplifies a mutation of these very characteristics. The intuitive synthesis achieved in this passage of Kallas' concluding summary is impressive, and the exceptionality, the omission from the scheme of Tammsaare and Aavik confirms this. Kallas links the cultural mutation with the change in the social environment (urbanization and a rise in cultural standards) and the educational leap. Thus, in these two exceptional portraits the focus shifts from "milieu" to "moment" - specifically on how the modernization of Estonian society influenced the mentality of the age. While modernization expressed itself primarily through urbanization, it is not insignificant that Kallas adds gender to her analysis: in the essay on Aavik's "Ruth", women's emancipation and individuation emerge as important additional markers of modernization. ${ }^{33}$

For Kallas the moment of turn-of-the-century Estonian culture is clearly characterized by upstart tendencies. In Taineian terms, milieu and moment have together caused an alteration of racial attributes - a deep transformation of the ethnos. The problems Kallas attributes to the individual upstart in a society of others of his kind grow out of the unresolved conflict between origins and environment, which hinders social progress (Molarius 2003). The Estonian upstart comes from the country, from agrarian society with its implicit peasant mentality, to live and study in town; in other words, he is a first-generation educated city-dweller. ${ }^{34}$ Kallas adds a critical remark here:

All of the obstacles and the privations which usually accompany too rapid a rise in cultural status can be felt in Estonia. This kind of first-generation society is free of all direct ties to tradition, both the good and the bad kind; nothing holds it down. As it grows, it cannot revert to a pre-existing cultural crystallization of long duration; it completely lacks the support which would be provided by an enduring cultural substrate. (Kallas 1918, 18.) ) $^{35}$

The upstart is thus a rootless fellow, a character who stands between classes and ranks. Kallas identifies both herself and the Young Estonians with this "transitional stratum". ${ }^{36}$

Thus what Kallas seeks to identify and illustrate in the oeuvre of the Young Estonians is on the one hand the presence of certain long-standing 
racial attributes, but on the other the effects of a deep alteration. From this double effort she draws the following conclusion: Young Estonia has grown "inseparably and organically... out of Estonian soil; in its deeper spiritual substance it partakes of the open country of Liivimaa and Tallinnamaa, that special Estonian atmosphere, where everything either has to ripen - or rot" 37 (Kallas 1918, 9).

Once again, this passage is undergirded by Taineian presuppositions. Kallas is pointing simultaneously to both milieu and moment - the open country around Livonia and the expanse of plains surrounding Tallinn, and the atmosphere of an age given to progress. The cultural life course of this age is cyclical, consisting of phases of growth, ripening, and decline. If one leaves aside the exceptions among the authors she portrays, (Aavik, Tammsaare, to some extent Tuglas) the developmental curve of Young Estonia would epitomize Estonian culture as a whole, a balanced linear flow which becomes obstructed by the admixture of several environmental ("milieu") factors that favour decline:

If there were nothing else about Young Estonia that was characteristically Estonian, this one characteristic - so typical of Estonian education - would emblematize its developmental course. Hovering above Young Estonia, despite all its effortful pursuit of culture, there is the curse of being too young, too windy, too restless. Indeed this is the outcome of the pressures of an era that is both opportune and hazardous for even-tempered progress. (Kallas 1918, 49.) (38 $^{38}$

\section{Milieu and inheritance as shaping factors of the Estonian psyche}

As has already been shown, Kallas uses Taine's explanatory schema to show that each of the authors she portrays reflects "only [a] fraction of the capital of a common race" (Kallas 1918, 222). Tacitly appealing to Taine, Kallas argues that the landscape and climate have shaped the natural attributes of Estonia over the course of centuries, and Ridala thus seems to her to be the most Estonian of all the Young Estonia writers:

The ponderous heaviness of this sensibility is quintessentially Estonian, as is the resistance to rise to emotional 'heights', and a demeanour which is outwardly peaceful despite all the quiet accumulated force pent up behind it. It is also characteristically Estonian that the direct expression of emotion is restricted to the ultimate degree, indeed, to the very point of being helpless to express it at all. This $\ldots$ is characteristic of the entire common Finnic race. (Kallas 1918, 112-113.) ${ }^{39}$

Ridala's poetry is maximally Estonian in the sense that it is able to express the superficial layers of the Estonian temperament (those characteristics shared by the islander and Estonians in general), while also reaching to the deeper layers, where the common Finno-Ugric traits of all the Estonian tribes can be found.

Kallas refers in passing to these same circumstances in the introductory essay of Nuori Viro: this land has been "the arena of devastating wars", 
in Suits' words, the "Land of the Winds" ${ }^{\circ 0}$ (Kallas 1918, 7). Estonia's geographical location has always been at the crossroads of East and West, and thus war and famine have repeatedly ruptured the balanced development of the Estonian people. The foregrounding of the consistent influence of a coastal island landscape and climate in Ridala's works allows Kallas to expound on yet more essential traits of the Estonian's temperament. Ridala has "the island landscape in his blood and brain ... This is not a general landscape, but a painting of the sea, determined by the land, made local to the extent that one might surmise a certain enclosure characteristic of the islander, demarcated geographically within clear artistic boundaries" ${ }^{41}$ (Kallas 1918, 104). Ridala's works thus represent "an enclosed, clearly bounded temperament" 42 (Kallas 1918, 117), which is confirmed by the additional observation that "Ridala opens his inner world of emotions only through the vehicle of nature" (Kallas 1918, 112). Furthermore, Kallas claims that "in this extreme self-enclosure there is something native not only to the islander, but also to Estonians as a whole"43 (Kallas 1918, 112). The literary works of Tuglas and Suits provide a wealth of examples to support an argument that the Estonian psyche has been shaped by a landscape of bog and marsh (cf. Kallas 1918, 85; 219; 222).

The features of a common Estonian "psyche" emblematized by Ridala's poetry differ markedly from the Estonian psyche as manifest in Tuglas' novellas. In her Tuglas essay, Kallas argues that the Estonian psyche consists of two elements. The "dayward side" is peaceful, phlegmatic, cold-blooded, and invulnerable to spiritual illnesses; it has been shaped by the clay soil in the fields, fruit orchards, and lush meadows placed among low hills. Tuglas' novellas make visible the other, nocturnal element - the aspect that is lively and excitable, given to extremes, tending to the fantastical and visionary, receptive to all mental and spiritual ailments, and shaped by bogs and marshes (Kallas 1918, 222).

What interests Kallas most in the portrait of Tuglas is the story of the development of the nocturnal side of the Estonian psyche. According to Kallas, wars, with the accompanying fear of persecution, increased the receptiveness of "a brain irritated for a lifetime by famine" 44 to fantasy (Kallas 1918, 222). She particularly emphasizes the impact of slavery: "The persistent and long-lasting state of physical and spiritual depression instilled by slavery doubtless intensified what Tuglas called 'graveyard imagery" (Kallas 1918, 221). ${ }^{45}$ Kallas concludes that Tuglas "received from the spirit of the Estonian race the gift and inheritance of nervous stimulation and a tendency toward the fantastical, the imagery of the graveyard" (Kallas 1918, 223). ${ }^{46}$ As in Ridala's oeuvre, the roots of Tuglas' imagery partake of shared Finno-Ugric traits (Kallas 1918, 220). "Graveyard imagery" draws upon folkloric poetry (such terrifying figures as the fetcher, the goblin, the incubus, the werewolf and the dog-faced man) as well as the traditional interpretation of the wolf's howling as the desperate cry of an imprisoned human soul (Kallas 1918, 220; 222). Tuglas is the direct descendant of "nameless creators of folk stories - Estonians' horror romancers; ... the sense of horror is in his blood... His instinct is never so true as when he treats fear, that sense of spiritual tension that, once its 
force and intensity ascends to the level of fear of death, can only be compared to the sometimes shocking impact of erotic experience on the soul." (Kallas 1918, 223; 224.) ${ }^{47}$

The preceding examples show that one of the structuring themes of Kallas' account of Young Estonia is inheritance: psychic phenomena and forms are ostensibly transmitted through the blood. Of particular interest are those psychic forms that exhibit low vitality, or a deficiency of the life force. With the widespread dissemination of Darwinist ideas of development at the beginning of the $20^{\text {th }}$ century, there was a shift in readings of Taine's theory: While in the $19^{\text {th }}$ century Taine was read primarily in terms of his analysis of environmental influences (milieu and moment), at the beginning of the $20^{\text {th }}$ century more attention was directed toward its racial aspect and its corollary, generational transmission and forms of inheritance (Molarius 1998, 100). For Taine, the topic of inheritance is connected to the notion of primeval granite, the site of ethnically specific instincts and intuitions located deep inside the individual "Lower down still at immeasurable distances, the primitive granite lies buried, the support of all else; powerful as the attack of centuries may be, time fails to remove it entirely." Elsewhere he writes: "This is the primitive foundation; it lasts for the lifetime of a people." (Taine 1875, 211; 221; 1915, 458, 464.) For Kallas, the works of Ridala and Tuglas bring to light very deep layers of the Estonian psyche, the psychic substratum Taine attributes to race.

Once again, this line of argument is not confined to individual writer's portraits, but is also elaborated on in the introductory essay. Here, however, Kallas attributes the broken line of development of the Estonian people to poor social circumstances, explaining this "unhealthy" developmental trajectory by means of the idea of reverse natural selection from Darwinian discourse (Kallas 1918, 12) as articulated by J. Aavik: “...the strongest, those with the most initiative and most capable of development" have consistently turned their backs on Estonian nationality and melted into other cultural substances; those who were left were clearly of lesser value (Aavik 1988, 5-8). Thus Kallas is not very optimistically inclined with respect to the spiritual and psychological potential of the Estonian race, a view she shares with several other Estonian "racial theorists" (Luiga, Tõnisson, Ridala, Tuglas) among her contemporaries (cf. Karjahärm 1993, 1347-1365).

Alongside the intellectual and psychic aspects of inheritance, Kallas is also interested in the content of cultural heritage. Young Estonia represents a third cultural stratum deposited upon two previous layers: the national awakening of the second half of the $19^{\text {th }}$ century, and the so-called Tartu renaissance of the beginning of the $20^{\text {th }}$ century (Kallas 1918, 13-15; cf. Olesk, this collection). Though this claim might imply that Young Estonia is a manifestation of cultural continuity, this is not quite the case; "The predisposing condition Young Estonia required was transformed intellectual atmosphere, which had been achieved by the process of urbanization in Estonia" ${ }^{88}$ (Kallas 1918, 20).

It follows that Kallas interprets Young Estonia as "free of all the ties of inheritance" 49 (Kallas 1918, 18), an effect of cultural discontinuity, the result 
of processes of social and economic modernization: urbanization, industrialization, the gradual growth of capitalism, and the spread of socialism, all of which helped weaken and efface cultural tradition.

Kallas attributes "most of today's Estonia's spiritual and bodily weakness" ${ }^{\circ}$ (Kallas 1918, 222) and forces retarding Young Estonia's development to these same processes of modernization which together with an inherited lack of vitality created a too-rapid change of environment and rise in cultural standards. Kallas borrows her epigraph to her study of Young Estonia from Tuglas: "The task of today's generation in Estonia is to create cultural and artistic life without traditions inherited from preceding generations. To suffer from the helplessness of the present while also bearing the burden of the past in one's bones, and to stretch out one's hands toward the ripe fruit of European art - this is the tragedy of this generation." (Kallas 1918, 5.) ${ }^{51}$

\section{The type of the modern age and the Estonian upstart}

The epigraph selected for the Young Estonia collection indicates that Aino Kallas aligned herself with Tuglas' view of the Young Estonia movement as the carrier of the identity for transitional generation, the same generational identity with which Kallas herself identified during her Tartu period. ${ }^{52}$ Among its other intentions, the volume of essays on Young Estonia is a retrospective, in-depth analysis of the circumstances in which Kallas shaped her own identity as an intellectual and creative writer, by means of which she also reaches toward a more general analysis of her times. Kallas focuses most intensely on the conditions of her own identity formation in a subsection of her portrait of Tuglas (in which she analyzes Tuglas' 1915 novel Felix Ormusson as a crowning example of Estonian literary decadence). A similar focused articulation is seen in essay on A. H. Tammsaare. According to Kallas, Tuglas understood quite early the concordant typicality between his own path to success and that of his generation. Thus his goal was to "create the type of the age" ${ }^{53}$ (Kallas 1918, 229).

The concept of the type is connected once again to Taine, who uses it in three senses: first, a characteristic of the environment or a period; second, as the model of an era (such as medieval times, the Renaissance, etc.); and third, as a universal type which has the capacity to accommodate the previous forms of the type. (Taine 1875, 211-214; 1915, 458-461.) In the first and second meanings the idea of the type refers to more superficial layers of the national temperament, which are likewise more subject to change. More resistant strata are found at the deeper level of "primeval granite", which contains the instincts and intuitions of the national temperament. Racial characteristics and those human characteristics shared by all regardless of race are located at the deepest level. (Taine 1875, 220-221; 1915, 464-465.)

According to Kallas, the protagonist of Tuglas' novel Felix Ormusson is connected to the first and second meanings of Taine's type. In the second sense, as Taine puts it, "The representative man, that is to say, the charac- 
ter who occupies the stage, and to whom the spectators award the most interest and sympathy, is the melancholy, ambitious dreamer Rene, Faust, Werther and Manfred, a yearning heart, restless, wandering and incurably miserable." (Taine 1875, 149-150, 158; 1915, 81; 87.) The diagnosis and the rhetoric of Kallas' Tuglas essay is similar:

When reading Felix Ormusson one is reminded of Goethe's, Werther, Constant's Adolphe, Musset's Child of the Century, Lermontov's A Hero of our Time... Jacobsen's Niels Lyhne, and Kierkegaard's Diary of a Seducer. The root of Ormusson's sickness is the same as theirs. That same great melancholy, which has no basis other than the sadness of the human condition that ate away at Solomon, and Werther in the form of Weltschmerz, the sadness to which the French Romantics gave the name "ennui..." (Kallas 1918, 230.)

Taine ties the unhappiness of his "type or model of the era" to two factors:

In the first place... he is too much accustomed to comfort ... and therefore he has become delicate, nervous ...less capable of accommodating himself to the course of life... On the other hand, he is sceptical. ... All the barriers which served as guides to minds having fallen, he rushes forward into the vast, confusing field which is opened out before his eyes; impelled by almost superhuman ambition and curiosity he darts off in the pursuit of absolute truth and infinite happiness. Neither love, glory, knowledge nor power ... can satisfy him ... This evil has been styled the great malady of the age. (Taine 1875, 150-151; 1915, 81-82.)

The exponents of Taine's ideas - Bourget, Nietzsche and other theoreticians of the modern age - identify various reasons for the melancholy and pessimism of the modern person: the increased well-being accompanying modernization and the accelerated dissemination of the new epistemology contingent on the victory of progress, which in turn relativizes previous certainties. In her characterization of Ormusson, Kallas also draws on the same intellectual tradition of critiques of modernism. Ormusson expresses the "sickness of the century" both in his incapacity to adjust to real life and in his superhuman thirst for knowledge (Kallas 1918, 229-234).

However, Kallas is also interested in Ormusson as the typological representative of the attitudes and positions of a much narrower period than the era at large. Claiming that "Ormusson is a book about an aesthete, the belle ame of the Estonian turn of the century transition" 55 (Kallas 1918, 236), Kallas regards Ormusson as a "period type", an early $20^{\text {th }}$ century Estonian intellectual with literary aspirations. Taine characterizes the period type as follows: "In short he is the plebeian of a new class, richly endowed with faculties and with desires, who, having for the first time attained to the heights of society, boisterously displays the trouble of his mind and of his heart. His sentiments and his ideas are those of an entire generation; hence it is that an entire generation has to elapse before we can see them disappear." (Taine 1875,$213 ; 1915,459$.) As can be seen in this quotation, the attributes of the period type last at most for one generation, twenty to forty years. Here Taine shows himself not as determinist but rather as a proponent of change 
and the rhythmic movement. For Taine the period type represents a certain transitional period, and his attributes are shaped by the characteristics of both the preceding and the following era.

For Kallas this transitional type is illustrated in the mentality of contemporary Estonian society and more specifically in Young Estonians and the literary characters they created. The protagonist of Tuglas' novel Felix Ormusson has "in his blood the lust for life and pleasure of a young race"56 (Kallas 1918, 234). The university students in Tammsaare's novellas are "born of the first generation, surrounded by the atmosphere of the new man" ${ }^{57}$ (Kallas 1918, 184). In the Young Estonia essay she sums these reflections up as follows: "It is quite possible that in the advancement of Young Estonia, the spiritual aspect is most important ... with Young Estonia it is just this new generation of Estonian intellectual life that is represented, the spirit of a new age, the new human being"58 (Kallas 1918, 21).

According to Taine a time of transition creates the conditions for the transformation of racial characteristics: "in order to change them a change of blood is necessary, that is to say, an invasion, a permanent conquest, and consequently, comminglings of race, or, at least, a change of the physical milieu..." (Taine 1875, 216-217; 1915, 461). The metaphors here are significant. Kallas' adopts and implements Taine's explanation in the case of Young Estonia: the transformation of racial characteristics encompasses both the change of environment (moving from the country to town) and many other consequences of overly rapid processes of modernization. As I argued earlier, Kallas uses the figure of the upstart to epitomize what she means by racial transformation. The Estonian society of upstarts is as chaotic and unformed as the psyche that corresponds to it: "it often seems fluid, vague, and full of surprises... It is still in the crucible, still in the process of formation, full of foreign substances, unconscious of itself, in turbulent motion, contradictory, often assuming unprecedented shapes. It could be considered neurotic, so restless is its appearance." (Kallas 1918, 19.) ${ }^{59}$

Kallas gives the most detailed characterization of this type of the upstart - Taine's transitional type - in her essay on A. H. Tammsaare. The characters of Tammsaare's novels, his upstarts, are on the one hand embodiments of the process of urbanization: "They have settled their accounts with the village; their intentions are clear and conscious" (Kallas $1918,184)$. On the other hand, Kallas seems to suggest that these characters belong to another era: "... despite this there is something amphibious about them, something that belongs to two places at once"60 (Kallas 1918, 184). Therefore these upstart types have not made a complete adjustment to their environment, and in Kallas' view they reflect urbanization both as breakthrough and tragedy. Both Tammsaare's university students and Tuglas' Felix Ormusson are interpreted by Kallas as halfway along in the transformation of peasant traits into something new. They may have acquired urban styles of behaviour, but in their psychic and emotional life they continue to depend and draw on agrarian society. They represent "the two ages commingl(ing) through a reciprocal encroachment, and each of them engenders the creations of the other, together with its own" (Taine $1875,284 ; 1915,501)$. 
In Kallas' view the problems of the Estonian upstart are most intimately connected with their excessively developed sense of Hunger - both physical and intellectual:

In their instincts there is doubtless something fundamental, just as their requirements are largely of a primitive nature... as if physical hunger... had not been completely satisfied yet. Today's Estonian society has a strong appetite, an uncontainable greed, a good instinct for gathering money." (Kallas 1918, 18.) ${ }^{61}$

Though here Kallas is describing the upstart in a material and materialist sense, her real interest is in the intellectual upstart. When analyzing the figure of Ormusson, Kallas strikingly summarizes his intellectual hunger as follows: Ormusson "wants to pass through the entire Darwinian process in one lifetime, from the amoeba to Übermensch"62 (Kallas 1921, 235). Kallas directs her critical barb at the ambition of the upstart society, bound and determined to achieve everything in a single generation. This goes against the Taineian viewpoint, according to which it takes several generations to arrive at a new racial form. In keeping with his organic concept of culture, Taine emphasizes that just like a living human being, cultures and works of art require time to grow. Thus Kallas' assertion that the Young Estonians' wish (and by extension the thrust of early $20^{\text {th }}$ century Estonian society) was to catch up with the "natural" evolution of several generations contradicts the laws of nature. This violation of natural growth of the social organism creates a condition of danger, giving rise to "the scars of extraordinary cultural development" in "all the manifestations of Estonian educational life" (Kallas 1918, 18). ${ }^{63}$ The negative consequences of this overly accelerated leap of development are summarized by Kallas in terms of the example of Tammsaare's university novellas. "Tammsaare's young people belong to an intellectually rich though weak-nerved generation, whose upstart quality is shown first and foremost by weakness of will and character; all of them suffer from cultural fatigue, and this is no secret for any of them; they already know ahead of time that sooner or later they will be cast off and left by the side of the road" ${ }^{64}$ (Kallas 1918, 182).

\section{Conclusion}

In the history of reception of Aino Kallas' Young Estonia collection, many different essays have been emphasized. Of Kallas' contemporaries, Juhan Luiga placed particularly high value on the portrait of Jaan Oks (Luiga 1995, 371), Nigol Andresen underscored the importance of the essay on A. H. Tammsaare (Andresen 1979, 108), Sirje Olesk has considered the introductory essay on the Young Estonia movement to the of most importance (Olesk 2003, 567). In the last decade, Estonian and Finnish scholars of women's studies have come back again and again to the essay on Aavik's "Ruth". This may leave the impression that the portrait of each individual author could stand on its own as an independent iteration. In this article, I have endeavoured to show that Taine's theory of three influences gives a coherent 
ideological grounding to Kallas' essays on Young Estonia, and that this can be seen at the levels of structure, vocabulary, method of analysis, and evaluation of the importance of the authors relative to one another.

At the same time one must not forget that Kallas' reading of Taine is specific to her times. Here the discourse of decadence is foregrounded: Kallas regards modern society (along with its representatives) as hypertrophied and thus in a process of decline, but also as exhibiting the symptoms of devitalized psyche, passed on from one generation to another. These different connotations of decadence meet in the concept of the upstart, which can be found in Taine's works as well in connection with the "period type". Kallas justifies the emergence of upstarts and the spirit of the upstart as too swift: a change in environment and educational progress, which paradoxically gives rise to a host of signs of decline. Thus the upstart represents par excellence the ambivalent experience of modernity. Through the concept of the upstart Kallas explores both the contradictions of the situation of cultural transition in Estonia and the larger surrounding context the transitional experience of fin de siècle European modernity.

\section{Notes}

1. Kallas published these pieces during her "Tartu period" in Estonian newspapers and magazines, but many of them were published previously in Finnish periodicals. In addition to ongoing book reviews, Kallas published four longer pieces of literary research: a foreword to the Finnish-language anthology of Estonian poetry, Merentakaisia lauluja [Songs from Beyond the Sea], (1911); a long essay, entitled "Koidula ja Kreutzwald" [Koidula and Kreutzwald] (1911) on the correspondence of two leading figures of the movement for national awakening in the second half of the $19^{\text {th }}$ century, poet Lydia Koidula and F.R. Kreutzwald, author of the Estonian national epic Kalevipoeg; Tähdenlento [A Shooting Star] (1915), a monograph on Lydia Koidula; the essay collection Nuori Viro. Muotokuvia ja suuntaviivoja (1918), which is the topic of this article (cf. Olesk, this collection).

2. The collection, translated by Tuglas was published in Estonian in 1921, with the title Noor-Eesti. Näopildid ja sihtjooned.

3. Taine's influence is mentioned in passing by Laitinen 1997, 63, Leskela-Kärki 2006, 329, and Hennoste 2006, 86).

4. Cf. Melkas 2006, 57-59; Kurvet-Käosaar 2006, 99-124.

5 . On the connections between the discourse of decadence and the concept of degeneration see, e.g., Kafitz 2004. This discourse begins to take shape in the mid$19^{\text {th }}$ century, when a split between two types of the experience of modernity comes into view.

6. Kallas' essay on J. Randvere's Ruth demonstrates that this temporalized modernity is also a gendered modernity. Cf. Fn 4.

7. [En ole vielä yhdenkään teokseni kanssa kamppaillut niinkuin virolaisten esseitteni, olen kiukutellut, kyllääntynyt ... Niin täytyy minun niitä nyt jo kolmatta vuotta märehtiä. Johtuuko se siitä, ettei essee ole alani, vai kaikesta siitä ihanasta ja vaikeasta, minkä kahden viime vuoden kuluessa olen elänyt, en tiedä.]

8. [Olen vihdoinkin löytänyt itseni ja ympäristöni.]

9. Tiit Hennoste, in a much later study, is however quite critical, and, in my view, rather unjustly dismissive of Kallas' treatment of Young Estonia. According to him, "her way of thinking is romantic, pronouncing judgments rather than supporting 
logical arguments with evidence" [Tema mõtlemisviis on romantiline ja postuleeriv, mitte loogiline ja tõestav] (Hennoste 2006, 87).

10. See the collection Kümme aastat: Noor-Eesti 1905-1915 [Ten Years: Young Estonia 1905-1915], which assembled the writings of several Estonian authors (1918), as well as Young Estonian insider Bernhard Linde's book "Noor-Eesti"kümme aastat [Young Estonia: Ten Years] (1919).

11. By the time Kallas' essay collection was published, two writers had completed their literary careers, Oks, and Aavik (alias J. Randvere). Three writers, Suits, GrünthalRidala, and Tuglas were in mid-career, while the major works of Estonian prose classic A. H. Tammsaare were some years in the future.

12. Essais de psychologie contemporaine (1883) and Nouveaux Essais de psychologie contemporaine (1885).

13. [Nous vivons dans une époque d'effondrement religieux et métaphysique... Non seulement nous n’avons plus, comme les gens du xvii siècle, un credo général... mais nous avons perdu aussi cette force de négation qui fut le credo à rebours du xviii siècle. Toutes les personnes qui, de près ou de loin, se rattachèrent au mouvement de combar dirigé par Voltaire eurent une certitude au moins, à savoir qu'ils combattaient l'erreur.... Telle n'est plus la conviction de notre âge de critique. Nous avons tant multiplié les points de vue, si habilement raffiné les interprétations, si patiemment cherché la genèse ... de toutes les doctrines, que nous en sommes arrivés à penser qu'une âme de vérité se dissimule dans les hypothèses les plus contradictoires sur la nature de l'homme et celle de l'univers. Et comme, d'autre part, il n'est pas d'hypothèse suprême qui concilie toutes les autres ... une anarchie d'un ordre unique sest établie parmi tous ceux qui réfléchissent. Un scepticisme sans analogue dans l'histoire des idées en dérive... Ce mal de douter même de son doute entraîne avec lui un cortège d'infirmités que tous connaissent: vacillation de la volonté, compromis sophistiques de la conscience, dilettantisme toujours à demi détaché et toujours indifferent.]

14. It is unlikely that Kallas had read Bourget's essays by the time she was writing the Young Estonia collection.

15. [Olisi ollut samettiin ja silkkiin ja kuosikkaisiin hännystakkeihin puettujen lastensa ja lastenlastensa kanssa kuuntelemassa tanskan prinssin Hamletin sanoja omalla kielellään.]

16. [On epäilematta jotain kohtalokasta henkisen kehitystempon erinlaisessa nopeudessa.]

17. In her secondary sources Kallas explicitly cites the theoretical texts of the Estonian writers themselves, mostly Tuglas and Luiga but also Suits, Grüntal-Ridala and others.

18. [ajanhenkeä, kansanhenkeä ja kunkin kirjailijayksilön erikoista luonteenomaisuutta.]

19. For Leino's own role in mediating Taine's ideas, see Kunnas 1980, 86-87.

20. [Aamupäivillä tein työtä, luin Tainen taiteen historiaa ja lepäsin Hillar vieressäni riippumatossa ajatellen milieuteoriioja]

21. [Luen paraikaa Tainen taiteen filosofiaa.]

22. [Kuid iseäralik on siin katse eestikeelse, sõna täies mõttes talupojakultura tüve külge seda ülikultura peenenenud võsu pookida]

23. [Kolmantena menin silmieni tähden lääkärille, hän arveli vasemmassa olevan trakooman oireita. Se on Saarenmaan lahja minulle, minun täytyy kai kestää tämäkin aito virolainen tauti, niinkuin olen läpäissyt virolaisen väsymyksen. Ihminen on sentään milieun orja.] The theory of "Estonian fatigue" was most likely propagated by J. Luiga, and referred to the putative burden of fatigue from the times of slavery, which was transmitted genetically to the following generations. Kallas treats this topic in her novel Ants Raudjalg (Laitinen 1997, 61-64; cf. Molarius 2003, 130, and Kurvet-Käosaar in this collection). 
24. In scholarly reference, the term 'parvenu' is also used instead of the term 'upstart'. I prefer the term 'upstart' due to its wider implications; 'parvenu' is frequently associated with the derogatory concept of the newly rich, as an individual who strives to secure a position in higher class purely for the purpose of economic advancement.

25. [Kirjailija, joka myöhään ja vaivollisen työn kautta vasta onnistuu, on kuten parvenu - nousukas - joka häpeää entistä köyhyyttään, s.o huonoja teoksiaan.]

26. For Kallas' connection with Brandes, see N. Andresen's article "Lehekülg Aino Kaldast ja Georg Brandesest" [A Page on Aino Kallas and Georg Brandes], (1983, 211-216]. As Andresen notes, Brandes' doctoral dissertation focuses on H. Taine's work (Andresen 1983, 219).

27. Maria-Liisa Kunnas hypothesizes that L. Onerva may have found her way to Taine through Bourget $(1980,95)$.

28. Philosophie de l'art is published in the years 1865-1869. It is an extensive series of lectures, where Taine approaches the nature of art from philosophical point of view and focuses more in-depth on the art of Greece, Italy and the Netherlands. I refer to the first volume of the English translation of the lecture series titled Lectures on Art (1875) and its Finnish translation titled Taiteen filosofia (1915).

29. [... oli todella dekadentti, ruumiillisesti ja sielullisesti.]

30. [Voi tuntua käsittämättömältä, mitenkä näennäisesti vailla varsinaisia edellytyksiä yhtäkkiä syntyy liike, jonka suuntaviiva tähtää ylikultuuriin ja muotohienostukseen, suinkaan suoranaisesti jatkamatta virolaisia talonpoikaissivistystraditsioita; jonka iskusanoilla: eurooppalaisuus, yksilöviljelys, estetismi, on niin outo ja yksinäinen kaiku keskellä ensimäisen polven nousukasyhteiskuntaa. On mahdollisesti hetkeksi taipuvainen pitämään nuoren kirjallisen polven myötääntuomaa henkistä kuormitusta vain maahantuonti tai kauttakulkutavarana, enämmän tai vähemmän elimellisesti vieraana viron henkiselle aatevarastolle, siirrettynä suorastaan suuremmista ja kehittyneemmistä kulttureista - siksi siteettömäna ympäristöönsä tai lähimpään sivistysmenneisyyteen esiintyy ensi katsannolta nuorivirolainen liike.]

31. [Taine on epäilematta oikeassa: jokainen lahjakas kirjailija kuvastaa tahtomattaankin rotunsa ominaisuuksia. Harvinaisissa tapauksissa hän voi olla kaikkien niitten eri ominaisuuksien synteesi, joista hänen rotunsa ja heimonsa psyyke on kokoonpantu. Mutta useimmiten hajaantuu rotuperintö, ja eri yksilöt heijastavat vain murto-osia suuresta yhteisesta rotupääomasta. Tämä rodullinen yhteenkuuluvaisuus voi olla kirjailijalla usein miltei tiedotonta, eikä se suinkaan aina käy yhteen sen käsitteen kanssa, mitä olemme tottuneet nimittämään kirjallisuudessa "kansalliseksi". Maailmankirjallisuudessa on kyllin esimerkkejä kirjailijoista, jotka aiheenvalinnaltaan ovat täysin kansainvälisiä, mutta silti syvemässä merkityksessä ovat oman rotunsa tulkkeja.]

32. [Mutta kaikki nämä aatteet, kaikki nämä säteet maailmankeskuksien suurista polttoauringoista ovat täällä taittuneet aivan erikoisesti virolaisen särmiön läpi. Ne on värittänyt virolainen temperamentti. Ne ovat saaneet vivahduksensa, yksilöllisen värityksensä samasta virolaisesta psyykestä, joka tuntuu Suitsin suorunoudessa, Ridalan saarenmaalaisissa maisemissa, Jaan Oksin epätoivoisessa sarkasmissa, Tuglasen novellien painajaistunnelmassa. Ja koko Noor-Eestin liike harhaotteineen, liikaiskuineen, liioitteluineen, on saman yhä selvemmin kiteytyvän virolaisen psyyken ilmaisu, joka kaikesta ulkonaisesta paineesta, kaikesta sisäisestä sekasorrosta huolimatta kulkee selkiytymistään, kristallisoitumistaan kohden.]

33. Cf fn $4 ; 6$.

34. The boundary between Kallas' explicit discussion of intellectual upstart and the economic upstart, which she sometimes implies, is blurry.

35. [Kaikki haitat, kaikki puutteet, mitkä säännöllisesti seuraavat ylen äkillistä sivistystason nousua, tuntuvat Virossa. Tällainen ensimäisen polven yhteiskunta on vapaa kaikista perinnäissiteistä, niin hyvistä kuin huonoistakin, mikään ei sitä 
sido. Se ei voi kasvaessaan kiteytyä minkään valmiin, jo ammoin olemassa olleen kulttuurikristallisoituman ympärille; siltä puuttuu tykkäänään tuki, jonka pysyväinen sivistysaines tarjoo.]

36. A number of such references can be found in the diary entries from the end of 1909 and the beginning of 1910, when the topic of the upstart was the topic of lively discussion in Finland (Molarius 2003). For example, on December 251909 Kallas writes in her diary: "In my soul I constantly make compromises on my life. Ah, what a transitional figure I am, neither one thing nor the other." [Ah, millainen välimuoto olenkaan, en sitä, en tätä] (Kallas 1953, 183); see also the diary entry for 3 January $1910(1953,185)$.

37. [... on kuitenkin eroittamattoman elimellisesti kasvanut virolaisesta maakamarasta, se on pohjimmiltaan osa samaa henkeä, joka muodostuu Liivinmaan ja Tallinnanmaan lakeuksilla tässä erikoisesti virolaisessa ilmastossa, missä kaikki täällä on tuomittu kypsymään - tai mätänemään.]

38. [Jollei siinä olisi mitään muuta Virolle luonteenomaista, niin ainakin sen kehityskulku, tyypillinen virolaisille sivistysilmiöille. Noor-Eestikin yllä on, kaikesta sen tietoisestä kulttuuripyrkimyksestä huolimatta, nuoren, liian nuoren, liian tuulisen viljelyksen kirous, liian levottoman, tosin hedelmällisen, mutta tasaiselle kehitykselle vaarallisen ajan paine.]

39. [Virolaista on hänessä hänen tunnelaatunsa raskasliikkeisyys, nousuhitaus, ulkonainen tyyneys, kaikista hiljaisesta, patoutuneesta voimasta huolimatta. Virolaista on hänessä samoin kaiken välittömän tunneilmaisun supistaminen mahdollisimman vähään määrään, niin, suorastaan sielullinen kykenemättömyys siihen. Se ei merkitse suinkaan tunteen kituliaisuutta, vaan eräänlaista miltei askeettista pidättyväisyyttä tunteen ulkonaisiin ilmaisumuotoihin nähden, tunteen ylen herkkää häveliäisyyttä, jos niin tahtoo sanoa, kuvaavaa koko yhteissuomalaiselle rodulle.]

40. [Hävittävien sotien tantereeksi...tuulimaaksi.]

41. [Se ei ole mitään ylimalkaista maisemamaalausta, vaan tietyn meren, määrätyn rannikon - paikallistettua siihen määrään, että voisi olettaa erikoista saaristolaiselle ominaista sulkeutuneisuutta maantieteellisen tarkassa taidepiirin rajoituksessa.]

42. [... erittäin selvä ja varmaviivainen temperamenttinsa...]

43. [... ilmaisee sisimmän tunnemailmansa yksinomaan luonnon välityksellä ... Epäilemättä on tässä äärimmäiseen viedyssä sulkeutuneisuudessa ei vain saarelaiselle, vaan koko virolaiselle rodullekin ominaista.]

44. [Elinaikaisen puolinälän kiihoittamat aivot]

45. [Juuri orjuuden synnyttämä, alituinen ja jatkuva masennustila, ruumiillinen sekä sielullinen, kasvatti epäilemättä tätä "kalmiston mielikuvitusta"...]

46. [...virolaiselta rotuhengeltä saanut antimiksi ja perinnöksi juuri hermoherkän ja fantastisen puolen, kalmiston mielikuvituksen.]

47. [... nimettömäin kansantarujen sepittäjäin suoranainen jälkeläinen, jotka kerran loivat virolaisen kauhuromantiikan ... Kauhu on hänellä epäilemättä jo verissä. ... milloinkaan ei hänen vaistonsa ole niin varma, kuin hänen käsitellessään kauhua, tätä sielullista jännitystilaa, jonka voimaa ja tiheyttä, sen kuolemanpeloksi kohotessa, voi verrata vain erotiikan synnyttämiin sielunjärkytyksiin.]

48. [Yhdä varma on, että Noor-Eesti tarvitsi syntyäkseen muuttunutta henkistä ilmakehää, minkä kaupunkilaistumiskulku oli ehtinyt Virossa luoda.]

49. [... on vapaa kaikista perinnäissiteistä...]

50. [suuri osa nykyistäkin virolaista henkistä ja ruumiillista kituliaisuutta...]

51. [Luoda taidetta ja kulttuurielämää ilman vanhemmilta polvilta perittyä taiteen ja kulttuurielämän traditsioita, - se on nykyhetken tehtävä Virossa. Kärsiä nykyisyyden saamattomuudesta, ja lihassaan ja luissaan samalla menneisyyden kuormaa kantaen kurkoittaa kätensä Euroopan kypsiä taiteen hedelmiä kohti, - siinä saman polven traagillisuus.] 
52. Cf fn $24 ; 25$.

53. [... luoda aikakauden tyyppi...]

54. [Ormusson on kaikkien näitten kuuluisain maailmantuskapotilaitten heimoa, hänen tautinsa on sama alkujuurta kuin heidänkin. Sama suuri melankolia, jolla ei ole muuta pohjaa ja perustaa kuin inhimillisen olemuksen ja elämisen traagillisuus sellaisenaan, joka Salomon Saarnaaja kalvoi kaiken turhuuden tuntona, Wertheriä "Weltschmerzinä" jolle Ranskan romanttinen koulu antoi nimen "ennui..."]

55. [Ormusson on kirja kaunosielusta, lähemmin sanottuna virolaisesta vuosisadan vaihteen kaunosielusta...]

56. [Hänellä on koko nuoren rodun elämis- ja nautinnohalu verissään.]

57. [He ovat kauttaaltaan ensimäistä polvea, uuden ihmisen ilmakehä ympärillään.]

58 [On hyvin mahdollista, että Noor-Eestinkin kehityksessä juuri sielullinen momentti on tärkein ... Noor-Eestin kautta esiintyy Viron henkisessä elämässä juuri uusi polvi, uudenaikainen henki, uudenaikuinen ihminen.]

59. [... se tuntuu usein fluidumilta, epämääräiseltä ja yllättävältä ... se on yhä vielä sulatusahjossa, vasta muodostumassa sekin, täynnä vieraita aineksia, tietämätön omasta minästään, hapuileva, ristiriitainen, usein hämmästyttäviin muotoihin pukeutuva. Sen voisi kokonaisuudessa sanoa sairastavan neuroosia, niin läikehtivä on sen ilme.]

60. [He ovat lopettaneet laskunsa maaseudun kanssa; heidän pyrkimyksensä on selvä ja tietoinen. Mutta siitä huolimatta on heissä jotain amphibista, kahtaanne kuuluvaa...]

61. [Sen vaistoissa on epäilemättä vileä jotain suuressa määrin alkeellista, samoin kuin sen tarpeet ovat suureksi osaksi yhä primitiivistä laatua. On kuin ei olisi sen suorastaan fyysillinen nälkä sanan varsinaisessa merkityksessä vielä täysin tyydytetty. Virolaisella yhteiskunnalla on tällä hetkellä voimakkaat ruokahalut...]

62. [... hän tahtoisi elämänsä kuluessa suorittaa koko Darwinin kehitysopin käytännössä, aina amööbista hamaan yli-ihmiseen saakka.]

63. [Poikkeuksellisen kehityskulun arvet ovat selvästi näkyvissä kaikissa virolaisen sivistyselämän ilmiöissä...]

64. [Tammsaaren nuoriso on älykästä, mutta heikkohermoista sukupolvea, jonka nousukkuus tuntuu ennenkaikkea tahdon ja luonteen heikkoudessa, sivistysväsymyksessä, jota he poikkeuksetta potevat. Se ei ole heille itselleenkään mikään salaisuus, he tietävät hyvin jo edeltäkäsin ennemmin tai myöhemmin jäävänsä tien oheen.]

\section{References}

\section{Research objects}

Kallas, Aino 30 June 1909: A. H. Tammsaare "Noored hinged" [A. H. Tammsaare's "The Young Souls"] Postimees nr 143. (1909a)

Kallas, Aino 1953: Päiväkirja vuosilta 1907-1915. [Diary from the years 1907-1915.] Helsinki: Otava.

Kallas, Aino 1954: Päiväkirja vuosilta 1916-1921. [Diary from the years 1916-1921.] Helsinki: Otava.

Kallas, Aino 31 December 1909: Noor-Eesti III. [Young Estonia III.] Postimees nr 31. (1909b) 
Kallas, Aino 1918: Nuori-Viro. Muotokuvia ja suuntaviivoja. [Young Estonia. Portraits and Trajectories.] Otava: Helsinki.

Kallas, Aino 1921: Noor-Eesti. Näopildid ja sihtjooned. [Young Estonia. Portraits and Trajectories.] Tartu: Noor-Eesti Kirjastus.

\section{Research literature}

Aavik, Johannes 1988: Rahvustunde nõrkusest Eestis. [On the Weakness of National Sentiment in Estonia.] Tallinn: Loomingu Raamatukogu.

Andresen, Nigol 1979: Terendusi. Uurimusi ja artikleid. [Studies and Articles.] Tallinn: Eesti Raamat.

Andresen, Nigol 1983: Suits ja tuli. Uurimusi ja artikleid. [Smoke and Fire. Studies and Articles.] Tallinn: Eesti Raamat.

Brown, Marshall 1997: Why Style Matters: The Lessons of Taine's History of English Literature. In: Marshall Brown (ed.), Turning Points. Essays in the History of Cultural Expressions. Stanford: Stanford University Press.

Bourget, Paul 1883: Essais de psychologie contemporaine. Paris: Gallimard.

Hennoste, Tiit 2006: 20. sajandi eesti kirjandusteadus Euroopa kirjandusteaduse taustal. 5. loeng Noor-Eesti ja positivism. Hüpped modernismi poole II. [20 ${ }^{\text {th }}$ century Estonian literary studies in relation to Europe. 5. lecture. Young Estonia and positivism. Leaps toward Modernism II.] Vikerkaar nr 9.

Kafitz, Dieter 2004: Décadence in Deutschland. Studien zu einem versunkenen Diskurs der 90er Jahre des 19. Jahrhunderts. Heidelberg: Universitätsverlag Winter.

Karjahärm, Toomas 1993: Tõuküsimus Eestis. [Race Question in Estonia.] Akadeemia 7.

Koskela, Lasse; Rojola, Lea 1997: Lukijan ABC-kirja. Johdatus kirjallisuuden nykyteorioihin ja kirjallisuudentutkimuksen suuntauksiin. [A Reader's ABC-book. Introduction to Contemporary Trends in Literary Theory and Criticism.] Helsinki: Suomalaisen Kirjallisuuden Seura.

Kunnas, Maria-Liisa 1980: Ympäristö taiteen ja yksilön muokkaajana. Tainen teoriat L. Onervan tuotannossa. [Environment as the Shaper of Art and the Individual. Taine's Theories in L. Onerva's Work.] In Auli Viikari (ed.) Kirjallisuuden tutkijain Seuran vuosikirja 33. [The Yearbook of the Finnish Literature Society.] Helsinki: Suomalaisen Kirjallisuuden Seura.

Kurvet-Käosaar, Leena 2006: Aino Kallase haakumisi J. Randvere Ruthiga' moodsa naise kuju pinnalt. [The Notion of the Modern Woman in the Works of Aino Kallas and J. Randvere's 'Ruth.] In: Mirjam Hinrikus (ed.) J. Randvere Ruth 19.-20. sajandi vahetuse kultuuris. [J. Randvere's "Ruth" in the Context of the Turn of the 19th Century.] Tallinn: UTKK.

Laitinen, Kai 1995: Aino Kallas. Uurimus Aino Kallase loomingu peateemadest ja taustast. [Aino Kallas 1897-1921. A Study of the Main Topics and Background of her Work.] Tallinn: Sinisukk.

Leino, Eino 1909: Suomalaisia kirjailijoita. [Finnish Writers.] Helsinki: Otava.

Melkas, Kukku 2006: Historia, halu ja tiedon käärme Aino Kallaksen tuotannossa. [History, desire, and the serpent of knowledge in the works of Aino Kallas.] Helsinki: Suomalaisen Kirjallisuuden Seura.

Molarius, Päivi 1998: Veren äänen velvoitteet -yksilö rodun, perimän ja ympäristön puristuksessa. [The urge of the voice of blood - individual under the pressure of race, heredity and environment.] In: Marja Härmänmaa, Markku Mattila (eds.), Uusi uljas ihminen eli modernin pimeä puoli. [Brave New Man, or The Dark Side of Modernism.] Jyväskylä: Atena Kustannus Oy.

Molarius, Päivi 2003: Will the Human Race Degenerate? In: Pirjo Lyytikäinen (ed). Changing Scenes. Encounters between European and Finnish Fin de Siècle. Helsinki: Suomalaisen Kirjallisuuden Seura. 
Olesk, Sirje 2003: Aino Kallas ja Noor Eesti kriitika. [Aino Kallas and Young Estonian Criticism.] Keel ja Kirjandus 8.

Stoupy, Joëlle 1996: Maître de l'heure. Die Rezeption Paul Bourgets in der deutschsprachigen Literatur um 1890. [The Reception of Paul Bourget in German since 1890.] Berlin: Peter Lang.

Taine, Hippolyte A.: 1883: History of English Literature. Translated by Henri Van Laun. London: Chatto \& Windus.

Taine, Hippolyte A.: 1875: Lectures on Art. Volume I. Translated by John Durand. University of California, San Diego.

Taine, Hippolyte 1915: Taiteen filosofia. [Philosophy of Art.] Translated by L. Onerva. Helsinki: Otava. 


\title{
“The vitality of primeval peasant blood"
}

\author{
The Hereditary Potential of Estonians in the Work of \\ Aino Kallas ${ }^{1}$
}

In January 1908 Aino Kallas wrote to Estonian poet and man of letters Gustav Suits, a member of the influential Noor-Eesti [Young Estonia] movement: "If I could now freely choose, I would no longer ask for roots in Finland nor in Estonia but in humankind at large where we could all take root and flourish"” (Kallas 1953, 63). Kallas admitted to no longer believing in the possibility of feeling completely at home in Estonia, while also having already become alienated from her native Finnish soul (Kallas 1953, 63). The writings and circumstances of Aino Kallas at that time, during her so-called Tartu period (1903-1917) make visible an identity crisis that, among other factors, was closely related to an alarming realization of the impossibility of seamless identification with any one culture or nation.

The question of roots finds frequent consideration in her diaries from these years, where, quite contrary to the position elaborated in the abovecited letter, Aino Kallas perceives roots (i.e., the blood inheritance of her family) as the very foundation of her being. "We are all deeply rooted in our past; in order to understand ourselves, we need to know our ancestors" ${ }^{3}$ she wrote to her aunt Ottilie de Pelinsky in 1908 (1953, 64). The topos of seeking roots culminates in the autobiographical novel Katinka Rabe (1920), Kallas' "Dichtung und Warheit" (see Laitinen 1997, 166) where she ties the beginnings of her identity as an artist to childhood summers spent in paternal grandparents' home at Kiiskilä. ${ }^{4}$ Nearly a decade later, in the foreword to her collected works in Estonian, Kallas again highlights close ties with her father's family, now placing her inheritance into the framework of race and heredity theories of the period.

[From my father's side] I come from a family ... imbued with wanderlust, in whom via marriage the blood of twelve different nations has intermixed in the course of a few generations ... throughout my life, I have deeply felt the impact of this mixed blood, on the one hand as an impeding and dispersing factor, and on the other as a source of much-valued artistic impulse. (Kallas 1929, 5-7.) ${ }^{5}$

An identity quest through paternal inheritance, linking Aino Kallas primarily to Finnish cultural contexts and the development of Finnish intellectual 
elites, ${ }^{6}$ is not the only aspect of her work that engages with the polemics of race, blood and heredity. Of equal importance is Aino Kallas' engagement with race polemics from the perspective of the potential and limits of the Estonian race, which is the subject of the current study. Kallas' short novel Ants Raudjalg (1907), as well as several short stories, for instance, "Vieras veri" and "Gerdruta Carponai", as well as the biography of Lydia Koidula, Tähdenlento [The Shooting Star], (in Finnish 1915, in Estonian 1918) quite intensively contemplate on the possibilities and restrictions of the Estonian race and blood. The subject of race and heredity is also touched upon in Aino Kallas' diaries, in her posthumously published memoir of her husband Oskar Kallas, Elämäntoveri [Companion for Life], (in Finnish in 1959, in Estonian in 1998), and in her monograph on Young Estonia, Nuori-Viro. Muotokuvia ja suuntaviivoja [Young Estonia. Portraits and Trajectories] (in Finnish in 1918, in Estonian in 1921), which has retained its critical value even today.

Finding expression in her fiction, biographical, and autobiographical writing and essayistic work most intensively during the first decades of the $20^{\text {th }}$ century, the question of race relates both to topical concerns of Aino Kallas' own life and to larger cultural debates over these issues in Estonian Finnish society. In the current article, I will analyse main thematic clusters concerning the hereditary potential of the Estonians, focusing on Aino Kallas' emphasis on the "vitality of primeval peasant blood"7 (Kallas 1915, 24).

Aino Krohn's engagement in 1899 to Estonian folklorist Oskar Kallas, a good friend and colleague of her half-brother Kaarle Krohn, was not warmly welcomed by all members of her family. A diary entry from February 1900 documents a conversation regarding her marriage with her brother-in-law Eemil Setälä, who accuses Aino of deserting her nation and points to the destructive influence of such decision to her personality: "Such an individual ... can no longer retain the unity of his/her personality" (Kallas 1952, 213). The core of the argument here is not merely abandoning one's nation but also, in Eemil Setälä's view, the value of the new nation that Aino Kallas has decided to adopt: "Who are Estonians really? A dying race ... if you want [your children] to grow up Estonian you need to prepare them from the start for the life of a peasant or a craftsman because there's no such thing as Estonian culture". (Kallas 1952, 213). ${ }^{9}$ Setälä disregards the fact that her sister-in-law is not going to marry an Estonian peasant or a craftsman but a man of letters soon to earn his doctorate from Helsinki University, a man who already at the time of his engagement had the makings of an outstanding member of the Estonian intellectual elite. This conversation can, in my opinion, be looked upon as one of the underpinnings of Aino Kallas' consideration of the Estonian race, a subject area that she explored in her work with a certain sense of defiance, seeking to prove, via a gallery of characters of modest native Estonian background, the stamina, vitality and great potential for the intellectual culture of that "dying race."

The interest of Aino Kallas in race and heredity is not exceptional for her time, as these issues spurned heated debates in Europe throughout the second half of the $19^{\text {th }}$ and the beginning of the $20^{\text {th }}$ century. According to Kai Laitinen, conceptions of race and heredity and Tainean milieu theory 
are part of the shared intellectual foundation of the era of realism at the beginning of the century $(1997,63)$. Strongly influenced by race debates in Europe, similar discussions in Finland and Estonia were particularly concerned with the potential of Finns and Estonians to become a cultured race, and the respective hereditary factors advancing and inhibiting such development. Aino Kallas had extensive knowledge of the race theories circulating in Europe, as well as debates around these issues in her more immediate contexts of Estonia and Finland. Perhaps she was even more immersed in Estonian race debates due to her close ties with the Young Estonia movement and the group of intellectuals (also including her husband) affiliated with the newspaper Postimees. Both groupings dwelt on these issues quite extensively. In a more indirect manner, her husband's field - folklore - may also have also stimulated Aino Kallas' interest in the history and characteristics of Estonian peasantry and its culture. ${ }^{10}$ This interest is visible in multiple diary entries made during the trips of the Kallas family to the island of Saaremaa, where Aino Kallas meticulously records the details of the life and customs of the local people, as well as in several ethnographic items decorating the home of the Kallas family (see Olesk 1998, 250).

\section{Race and heredity debates in Europe}

Multiple theories of race and heredity circulated in late $19^{\text {th }}$ century and early $20^{\text {th }}$ century Europe. One foundation of race debates was Darwin's theory of the evolution of the species that was developed further in relation to the evolution of the human race by John Haycraft, Francis Galton, and Karl Pearson. Of enormous influence was Hippolyte Taine's theory of race, milieu, et moment; Arthur Gobineau's treatment of the inequality of races; and Cesare Lomboro's ideas of mental health, genius and criminality of men and women. These texts were also widely read, debated and translated into many languages. One of the core concerns of race debates was the establishment of the hierarchy of races, with Gobineau's Essai sur l'inégalité des races humaines (1853-1855) as a core text that featured the division of humankind into higher races with strong potential for intellectual achievement and social organization, and lower races who would not amount to such accomplishments even in favourable circumstances. Of the three main racial groups, or primary varieties - white, yellow and black - the intellectual, psychological and physical qualities of the white race exceeded those of the others many times (Gobineau 1856, 439-460). ${ }^{11}$

In addition to the emphasis on the supremacy of the white race, an important focus of race debates in Europe was the advancement of the properties of different variations of the white race, or eugenics, a term coined by Englishman Frances Galton who based his research on Darwin's theory of evolution and focused on variation in human population. Galton saw the aim of eugenics as "bring[ing] as many influences as can be reasonably employed, to cause the useful classes in the community to contribute more than their proportion to the next generation" (Galton 1909, 38). Galton's intellectual heir Karl Pearson, a keen proponent of the hierarchy of races, 
emphasized the need to strive toward a harmonic relationship between the members of higher races, and to refrain from any contacts with lower ones: "the superior race must either eject the inferior, or, mixing with it, or even living alongside it, degenerate itself" (Pearson 1905, 46).

Although the white race was generally placed at the top of race hierarchy, there were variations within the category itself as well, based on the impact of environment and patterns of intermixture. The most valued criterion in a race variation (in other words, a nation) was physical and mental uniformity, as strong differences within the scope of one nation were regarded as a shortcoming. In a thorough and detailed essay on race issues that also contains an extensive survey of different race theories, Estonian folklorist and linguist Villem Ridala views the intermixture of different races in England as a prime example of "successful blending", producing as a result "a supreme nation" while the same phenomenon in France exemplifies an unfortunate "chaos of the blood" (Ridala 1913, 211). Although Estonian and Finnish race considerations echoed the accepted race hierarchies on a general level, they sometimes differed on the rules of intermixture of different varieties of the white race. For instance, in Villem Ridala's view, despite centuries of German subordination, Estonian blood had not intermixed with German to any noteworthy extent, thus preserving its distinctive primeval development potential (Ridala 1913, 341).

Aino Kallas' evaluation of her varied paternal blood heritage highlights a mainly successful intermixture of different European races, though it emerges simultaneously problematic and alluring when looked at from gendered point of view. In the process of getting to know her father's family as a grown-up woman, she became aware of cases when the behaviour of the family's women (often self-consciously) goes against traditional gender roles and norms of female propriety. Kallas attributes such rebelliousness to the restless blood running in their veins (see, e.g., Kallas 1952, 176; 1953, 147). Furthermore, she also views herself an heir to such restless blood and at different stages of her life is determined to fight against its demands, or view yielding to it a prerequisite for attaining full womanhood and self-realization as an artist. Aino Kallas' treatment of the question of mixed blood in relation to the potential of Estonians will be addressed below.

Hippolyte Taine's highly influential theory of race, environment and epoch (race, milieu, et moment) brought into race debates the need to consider hereditary factors not independently but in relation to both the environment and the general mentality of the times (see Taine 1890, 17-22). According to Taine, the functioning and development of a particular society or civilization of a certain period was organized by force maîtresse, "a universal force, everywhere present and active, governing all great issues and directing all major events" (Taine 1904, x-xi quoted in Biddiss 2003, 73). In addition to hereditary factors, culture and society are shaped by the environment (le milieu) that Taine formulated as "physical or social circumstances [that] disturb or confirm the character committed to their charge" $(1890,11)$. Among environmental influences, climate was one important factor through which Taine explained differences between German, Greek, and Latin races, attributing to the cold and damp climate the fact that the 
Germans are "prone to drunkenness and gluttony, bent on a fighting, bloodspilling life" and making milder and enjoyable climate responsible for the inclination of Greek and Latin races toward a harmonious and sophisticated development of state structures, art, science, and letters (Taine 1890, 11). In the introduction to the collection of essays on the Young Estonia movement, Aino Kallas highlights the geographical position of Estonia as a factor that has played an important role in the development of the Estonian race. Her focus, however, is not on climatic conditions but on a realization that as a passageway between East and West, Estonia has for centuries been "an arena of devastating wars"12 (Kallas 1918, 8). The third, most volatile factor shaping the life of an individual and society for Taine was the epoch (le moment), the mentality characteristic of a certain era, "the long dominations of one intellectual pattern, or a master idea" shaping great "historical currents" (Taine 1890, 13). ${ }^{13}$ Environmental factors played an important role in other theories of race, in particular on the scale of advancement versus degeneration, and for the most part there is agreement that poor living conditions, poverty, alcoholism, and high occurrence of mental disorders caused a race to degenerate. While some recommended complete elimination of risk groups in a given nation, others focused on elimination of social causes leading to degeneration.

As several researchers have pointed out, degeneration was very much part of the social vocabulary of fin de siècle Europe, "knowledge about degeneracy quickly achiev[ing] the status of popular wisdom" (Arata 1996, 3; see also Pick 1989). A leading authority in the question of degeneration in Europe whose ideas also had an immense influence in the Scandinavian countries was French psychiatrist Bénédict Augustin Morel, whose work advanced the idea of physical and mental degeneration as an increasingly accelerating force leading toward the decline of the Western world. ${ }^{14}$ According to Morel, degenerative traits intensified with each successive generation, culminating in complete physical and mental decay (Moore 2002, 139). Degeneration was also a subject of intense discussions and varied literary representations in Finland and in Estonia, focusing on the weakening and decay of Western civilization at large as well as on the impact of the "unsound human component" and the flourishing of immorality, crime and mental diseases (Molarius 2003, 121, see also Rojola 1999, 165-183; Karjahärm and Sirk 1997, 284-297). In Finnish literature of the beginning of the $20^{\text {th }}$ century the theme of degeneration is manifested in the acceleration of vices and weaknesses as well as in the emphasis on the destructive influence of the city environment on hereditary qualities developed on the basis of country environment (Molarius 2003, 121-142). ${ }^{15}$ In Estonian literature, degeneration also often emerges in relation to the strengths and weaknesses of the German blood. ${ }^{16}$

The most original critical development of the theory of degeneration in Estonia was perhaps Johannes Aavik's ideas of "reverse selection". Aavik, one of the members of the Young Estonia movement, noted that the Estonian race could be characterized by "a general sense of stuntedness [and] physical, moral and intellectual deficiency" ${ }^{17}$ (Aavik 1988: 5) that he attributes partly to the inborn inferiority of the Estonian race, partly to the fact that 
natural selection in an Estonian context means that "stronger, smarter and more beautiful specimens" have moved away (mainly via Germanization) from their Estonian roots (Aavik 1988, 5-7) and are thus lost to the Estonian race. Aino Kallas mentions reverse selection in the opening chapter of her Young Estonia collection, but refutes the argument with her claim that in terms of intellectual development and education, Young Estonia represents the second, or even the third generation (Kallas 1918,13) thus showing that even if such phenomenon exists, its influence is nevertheless limited. Her novel Ants Raudjalg (1907) that I will briefly discuss below offers a more pessimistic treatment of the topos of degeneration.

The idea of degeneration was also central to Cesare Lombroso's work on the racial qualities of men and women and their criminal inclinations (Luomo Delinquente, 1889; La Donna Delinquente, 1893) as well as in his extremely influential theory of the interrelationship between genius and insanity (L'uomo di Genio, 1888). Drawing attention to the frequent occurrence of episodes of insanity in the lives of many men of genius through history, Lombroso proposed that genius in man develops at the expense of other qualities, most often the development of the nervous system (Lombroso 1896, v). ${ }^{18}$ It is important to note that Lombroso's definition of genius was clearly gendered as in his view, "women of genius [were] rare exceptions in the world" $(1896,137)$. Lombroso does not regard as a factor of much importance women's historically limited access to education, professional self-realization, or participation in social and political life. In his opinion, "had [there] been in women a really great ability in politics, science, etc., it would have shown itself in overcoming the difficulties opposed to it" (1896, 138).

Lombroso is also viewed as an enthusiastic proponent of the correlation of brain size and mental capacities, another highly misogynistic paradigm that was extremely popular at the end of the $19^{\text {th }}$ and the beginning of the $20^{\text {th }}$ century. According to the brain size theories, the smaller weight of woman's brain was believed to imply lesser mental and artistic skills. Lombroso's work, in particular his consideration of the female criminal, has been viewed as "systematic exposition of female inferiority" including the functioning of the senses, intelligence, and moral sense (Rafter and Gibson 2004, 9-10, 266). The diaries of Aino Kallas indicate that she was familiar with Lombro's work; his ideas were also a subject of discussion with Estonian psychiatrist Juhan Luiga (see Kallas 1959, 259). Aino Kallas was painfully affected by the misogynistic brain-size paradigm, and tackled it in an ironic short story "Nainen, jolla oli aivot" [The Woman with a Brain] (1912) and in various diary entries, including a well-known comment upon reading Otto Weininger's Geschlecht und Charakter (1903): "I have never desired to be anyone but a woman, yet I envy men for the few more grams of brain matter they have"19 (Kallas 1953, 75).

Lombroso did not underestimate the role of the man of genius in the development of nations, but nevertheless emphasized that due to "the frequency of genius among lunatics and of madmen among men of genius ... the destiny of nations has often been in the hands of the insane" $(1896,386)$. By revealing close connections between genius and mental disorders, Lom- 
broso wished to moderate unconditional admiration toward genius. Paradoxically, his understanding of genius became a general model of assessing the intellectual and artistic potential both of individuals and nations, a model where an ordinary 'normal' person acquired a negative connotation. In the work of Aino Kallas, Lombroso's direct or indirect influence can be traced in Tähdenlento, the biography of the Estonian poetess Lydia Koidula, as well as in her manner of perceiving her husband Oskar Kallas.

\section{Race issues in Estonian context}

Most works of Aino Kallas where race issues play an important role were written during the period when they were the subject of heated debates in Estonia, the most important of which were held in the circles (Noor-Eesti and the circle of the newspaper Postimees) that Kallas frequented herself. Race issues were addressed by Villem Ridala, Johannes Aavik, Jaan Tõnisson, Juhan Luiga and others. ${ }^{20}$ Ridala published an exhausting study entitled "Tõu küsimus" [The Problem of Race] in 1913 where, relying on the works of several different European race theorists, he provided an outline of the key questions of European race debates, seeing the importance of race theories in their focus on "basic elements of national identifications, primeval essences" ${ }^{21}$ (199). In addition, Ridala provides a detailed overview of the physical and intellectual qualities of different races (including the Finno-Ugric, Finnish, and Estonian races), of the development and hierarchy of races, of race purity and the peculiarities of race mixing, and of interrelations of the race and environment (1923, 199-363). Ridala valued the Estonian race variation highly, claiming that the Estonians' "intellectual contribution that they had managed to offer over centuries, first to the Baltic German-language environment, then, to an extent, to Russia and finally, into the educational work in Estonia" ${ }^{22}$ is a firm indicator of its high value $(1913,341)$. Ridala's evaluation of the Estonian race differs considerably from that of Johannes Aavik and Jaan Tõnisson. As a means of modernizing the national political programme, Tõnisson mostly highlighted different shortcomings (caused mainly by poor social conditions) in his treatment of race issues (Karjahärm and Sirk 1997, 292). Tõnisson staked the improvement of the Estonian race on the improvement of social conditions, at the same time underlining the importance of remaining faithful to peasant culture and cautioning against a European "super culture" characteristic of the city environment (Karjahärm and Sirk 1997, 292).

Among Juhan Luiga's statements about race, "Põhjavaim" [The Northern Spirit], (1912), which also influenced Aino Kallas, can be considered of high importance. Focussing on the image of the witch or the sage and the phenomenon of ecstasy, Luiga analyses the folk culture of the Northern peoples, attempting to assess the ability of the northern race for "higher intellectual efforts" $(1995,206)$. Especially in relation to the ecstasy, a phenomenon that, on the one hand, indicates great creative potential and on the other hand, borders on madness, Luiga's argument relates to Lombroso's notion of the genius. This relation can also be traced in Kallas' Tähdenlento and Nuori- 
Viro; the latter containing direct references to Luiga in treating "the tendency of Estonians towards neurasthenia" ${ }^{23}$ (Kallas 1918, 221). Relying on Luiga's claim about the leaning of the northern peoples towards mysticism and magic (Luiga 1995, 204-205), Kallas asserts that despite the "materialistic face" of the society of the first decades of the $20^{\text {th }}$ century, "fantastic features" have not disappeared in the Estonian people (Kallas 1918, 220). The fantastic element is at the same time related both to the experience and fantasy of fear: "It looks as if the scared fantasy of people who have been worn out by centuries of slavery has, willingly or not, been searching for the reason for fear and despair everywhere" 24 (1918, 221). According to Kallas, such features, developed as a result of the burden of slavery, also contain the potential for creating higher culture. The most convincing analysis of this can be seen in Friedebert Tuglas' analysis of artistic character in the collection Nuori-Viro.

\section{From centuries-long exhaustion to the vitality of native blood}

There is yet another theory of Luiga concerning the characteristics of the Estonian race that greatly influenced Aino Kallas. According to Luiga, Estonians' development into a capable and efficient cultural nation was hindered by centuries-long exhaustion, carried on from generation to generation (see Laitinen 1997, 63-64). Kallas develops the idea of such exhaustion in her short novel Ants Raudjalg (1907) where unexplainable passivity and rapid burnout prevent Ants Raudjalg's development, powerfully conveyed through numerous tropical and thematic variations. ${ }^{25}$ The closure of the novel is ambivalent: it does not offer clear indications of what Ants Raudjalg's future will be like. Realising that a natural continuation of education would unavoidably take him abroad "to fertilise the endless fields of Russia" ${ }^{26}$, he drops out of school and returns home only to find, to his great disappointment, that "home was not what it used to be and his father had grown old and crushed by life" 27 (Kallas 1907, 132). Yet the novel ends on a more optimistic note. On a high hill near his home, Ants Raudjalg envisions the appearance of a new generation:

...others will come, who are more powerful than we were, less demanding and less selfish ... who will not let go of their native soil ... but leave behind harvest celebrations and dances by the [village] swing, [of young girls] with bunches of ripe berries in their hair, to the next generations. (Kallas 1907, 133. $)^{28}$

Such vision about the potential of the Estonian race supports Jaan Tõnisson's views of rural culture as the source of people's life force (see Karjahärm and Sirk 1997, 292). Similarly to Tõnisson's ideas, Finnish race debates at the turn of the $19^{\text {th }}$ and the early $20^{\text {th }}$ century also saw the abandonment of simple, natural, and hard life, characteristic to the Finnish race for relocation to demoralised town environment as a source of degeneration. It was believed that such a change weakened the primeval racial qualities of the country people (Molarius 2003, 125). 
Centuries-old exhaustion, however, cannot be taken as the prevailing quality of the Estonian race in the work of Aino Kallas; rather it is the "vitality of primeval peasant blood" (Kallas 1929,26) that emerges as the most prominent feature. This notion was central to those race discussions of the time that focused on nations with longer folk culture and shorter literate culture, a category including the Estonians and the Finns. In her biography of Koidula, where this phrase comes from, Kallas characterises this disposition in a dual way. On the one hand, it is the "straightforwardness of an act, the coming-topower of a powerful, immediate instinct" and, on the other hand, "a need to perform, a thirst for audience and admiration" (Kallas 1915, 24). ${ }^{29}$

In terms of Aino Kallas' work in general, it is rather the former description, aimed at the act and a sense of willpower that characterises her treatment of the primeval Estonian blood. In such manner, the characteristic features of the Estonian race emerge in Ants Raudjalg as well as in the short story "Bernhard Riives", a story of "a peasant [who] straightened the back of seven hundred years of slavery"30 (Kallas 1995, 10). In the short story about Ingel, a wet nurse from Sõrve, who "slowly emits Estonian strength ... healthy blood ... into a small tender offshoot, whose blood had grown paler and paler over generations" ${ }^{11}$ (Kallas 1957, 392), Estonian blood heritage is not revealed as a conscious part of the protagonist's personality, but rather, as a part of some wider force or energy. Ingel's most important act, her decision to abandon her duties as a wet nurse and stay with her own child, can be explained by the instincts dictated by blood. The climax of the story powerfully displays Ingel's irresistible wish, even urge, to use the strength of her blood in furthering her own child and her native blood.

The vitality of healthy peasant blood also emerges in Aino Kallas' perception of her husband Oskar Kallas. In her diary, Aino Kallas always describes Oskar as a harmonious and wholesome person who is also her centre of stability: "The ties connecting me with Oskar are unbreakable. Everything that is healthy, joyful and natural in me is longing for him" ${ }^{32}$ (Kallas 1953, 123; see also Kallas 1953, 22, 85, 89, 125, 241, 256). On the other hand, such quiet harmony and normality is also a problematic aspect in the their marriage, as it does not satisfy the more sophisticated intellectual and aesthetic needs of Aino Kallas that she herself relates to "the spirit of modernism" and her brain's new way of thinking (Kallas 1953, 185). This discord reaches its peak in the late 1910s, when Aino Kallas falls in love with Eino Leino in whom she finds a soul mate. Torn apart by inner conflicts, she notes in her diary on 14 May 1917:

I chose Oskar, a man both bodily and mentally as healthy as possible, with the race instincts of my youth: for my future children. Him, the other I have chosen as an individual, for myself, with the instincts of my sensitive, sophisticated and jagged mental organism. (Kallas 1954, 102). ${ }^{33}$

Toward the end of her life, when Kallas made an attempt to write a memoir of her husband just before her death, Aino Kallas again characterises Oskar Kallas in a similar key, also mentioning Juhan Luiga's argument of the relation between normality and genius, influenced by Lombroso. 
Estonian psychiatrist Juhan Luiga once claimed that Oskar Kallas is both spiritually and bodily as close to the ideal of a normal person as possible. Coming from a cynic and a doubter ... such characterization in itself excluded true genius that, if looked at from the same perspective is, in most of its manifestations a sick and pathological exceptional phenomenon. (Kallas 1959: 259.) ${ }^{34}$

While initially, Oskar's normalcy was a strong expression of the strength of peasant blood that had both attracted and disturbed Aino Kallas, in her older years she emphasized only its strong points: "The main characteristics of Oskar Kallas ... were, I should say, harmonious and in accord, thus avoiding larger conflicts" ${ }_{35}$ (Kallas 1959, 259). Especially during their Tartu period, marital relations between Aino and Oskar Kallas were quite complicated and it is possible that Aino Kallas may have wished to compensate for the burden of those times at the end of her life with the book, in it echoing still in the 1950s the arguments of race debates at the beginning of the century.

\section{Paradoxes of mixed blood}

For Aino Kallas, the wholeness and harmony of Oskar's character could be traced back to his pure, unspoilt "thoroughly Estonian blood; concerning the race, he was absolutely unmixed" ${ }^{36}$ (Kallas 1959, 27). In contrast, Aino Kallas describes herself again and again as a result of the blood heritage of "twelve different nations" (Kallas 1929, 5-7). The binary of pure versus mixed blood forms a thematic thread that runs also through the fictional work of Kallas, finding consideration from different, sometimes contrasting perspectives. The problematics of mixed blood is, for example, raised in several short stories of Kallas' earlier period, including "Gerdruta Carponai" and "Vieras veri" [Alien Blood], both in the collection Vieras veri [Alien Blood] (in Finnish in 1921, in Estonian in 1922). The main character of the short story "Gerdruta Carponai" - the daughter of a German parish minister on the Island of Saaremaa - is the only one in her village and its neighbourhood to survive the plague that ravished Europe and Estonia in the first years of the $18^{\text {th }}$ century. Leaving the extinguished village and wandering, half-mad, in the woods and bogs of Saaremaa, Gerdruta hallucinates of the end of the world. She arrives at the seashore in the morning and suddenly spots a human footprint in the damp sand (Kallas 1957, 302). This overturns her already firmly-set vision of the end of the world and of herself as the last living human being. "A human footprint! The world was not forsaken after all. ... And the proud and noble Gerdruta bowed deeply ... and humbly kissed the stranger's footprint in the sand" ${ }_{37}$ (Kallas 1957, 303). The person who has left the footprint does not remain unknown for long; it is a young man wearing ordinary peasants' clothing and introducing himself in the following manner: "I am Laes, Kadariku Laes, from that hut over there" ${ }^{38}$ (Kallas 1957, 303).

It is in this manner that the ordinary Estonian peasant and a German noblewoman meet in the world where there are "no free people and slaves, no noblemen and peasants, no classes and ranks any more" 39 (Kallas 1957, 
304) and become the foremother and forefather of a new island race: "In their hot embraces on a straw cot flared up their fear of death and the thirst for life of the future generations" $4^{\circ}(1957,305)$. The initial balance between the blood heritage that the man and the woman bring into their new family is, however, upset at the end of the story, when Gerdruta is characterised in the following way: "She left this world just like a stone falls into its grave in a soft bog; she was forever engulfed in the low rank of her husband, among the family of strangers, abandoned by her own family and class. Her children were fishermen and slaves" ${ }^{11}$ Kallas $(1957,306)$. Although the "new race" of the coastal parish of the Island of Saaremaa sprang forth from two different sources, Kallas lets one of them run dry, allowing only the Estonian peasant race to live on. Considering the plot of the story that proceeds from the equal beginnings for two different races - a German noblewoman and an Estonian peasant man, both untouched by the plague, in good health and able to reproduce - such conclusion is somewhat ambivalent in terms of Kallas' evaluation of the potential of peasant ancestry. It can be argued that in a given context or environment, it has stronger endurance potential while (at least for the time being) it harbours few other potentials beyond mere survival.

"Alien Blood", another short story of the same collection, offers a different scheme of racial intermixture. The story focuses on a brief romance between Reet, a girl from a coastal village, "the freshest girl of the purest blood on the islands"42 (Kallas 1957, 419) and a man who has washed to the shore by the sea. The man's "hair was black as tar ... so black that it had almost a greenish hue ... his body was russet and he had the images of blue anchors [tattooed] on his arms"43 (Kallas 1957, 422). The sailor from a foreign country leaves the village after having recovered from the shipwreck, "but nine months after his departure, Treiali-Reet gave birth to a son with black hair and russet skin"44, and her son and his offspring become sailors, who "are the best in their work on the island, like cygnets or ducklings, in the waves since their early days" 45 (Kallas 1957, 424). The story closes with a comment on race: "In such a way, the fair Treiali-Reet became a foremother to a dark race, whose blood carried braver and hotter rhythms and who were filled with yearning for far-away waters and adventures" 46 (Kallas 1957, 424).

The events of both of these stories take place on the Island of Saaremaa that for Aino Kallas was first and foremost the home of her husband of pure and unmixed blood. The logic of Oskar Kallas' racial background is closer to "Gerdruta Carponai" illustrating also Ridala's claim about the regularities of mixing the German and Estonian races. In his discussion of race, Ridala discusses the extent to which the German presence and prevalence since the $12^{\text {th- }} 13^{\text {th }}$ centuries has affected the development of the Finno-Ugric race, eventually drawing the conclusion that the influence cannot be large, as the changes, "if they cannot be assimilated and integrated, should have been destroyed and filtered out by the race's self-purification in the course of time" 47 (1913, 320-321). "Alien Blood", on the contrary, refers to a different kind of regularity in the mixing of bloods. In the son of fair-skinned Reet, it is the dark, "alien" blood that will dominate together with the properties it carries - bravery, adventurousness, inherent sailor skills - which will become 
the characteristics of a new race. Such a scheme could be interpreted as evoking the blood heritage of Aino Kallas' paternal family. When outlining the history of her family in Katinka Rabe, Kallas emphasises how those among her ancestors who can be characterized by a more active and adventurous disposition and thirst for new knowledge and experience are responsible for the advancement of the family. At the same time, Katinka's grandmother Mummuli, the mistress of the Hovi (Kiiskilä) manor, is a generalised image of different blood heritages who at the same time also symbolises a standstill, a power that is already fading and vanishing. Although the novel covers only the early childhood years of the protagonist Katinka, we can sense that Katinka will be able to mobilize the (blood) heritage of her family again. Katinka's range of activities also subverts the norms prescribed for her class, bringing her into immediate contact with the peasants' world and its robust sources of vitality harbouring a great developmental potential. ${ }^{48}$

The problem of mixed blood emerges most sharply in Kallas' biography of Lydia Koidula, the first chapter of which contains a detailed overview of Koidula's ancestry. Koidula's paternal heritage is valued very highly; the much-repeated phrase "the vitality of unspoilt primeval peasant blood" originates here, characterizing the features that "can again be found in Möldri-Mats's grandson's daughter" 49 , i.e., in Koidula (Kallas 1915, 24). Kallas uses a notion familiar from Scandinavian race debates, adding, however, a new nuance to it by introducing a variety of characteristics not related to peasant culture but to the status of craftsman. Forming an interesting link between manual skills and the type of creativity necessary for good handicraft work and verbal/literary talents, Kallas draws attention to one of Koidula's paternal foremothers, Malle from the Kuldkepp family, "a craftsman, a weaver's daughter", who brings "more mobile and lighter characteristics, and most probably even verbal talent" ${ }^{50}$ into the family (Kallas, 1915, 24). Kallas also highlights the weaver's daughter's “joyfulness and light way with words" 51 (1915, 25), which form a sharp contrast with the characters of Koidula's maternal ancestors who are inclined toward melancholy and mental instability. Already the very first words that introduce the mother's family sound ominously in the biography: through Emilie Koch, Koidula's mother of German nationality,

'alien blood' originating from a strange, sickly and neurotic race became mixed with the powerful blood of Möldri-Mats and the fair blood of Malle Kuldkepp. It penetrated the previously healthy organism like some disintegrating substance, like a germ of illness, whose destructive effect can be perceived already in the next generation. (Kallas 1915, 28.) ${ }^{52}$

Kallas here opposes the strong vivacious young blood of a developing race and the blood of an old cultured nation, overdeveloped and already degenerating. Although such juxtaposition may seem exaggerated, it reflects one of the period's viewpoints toward the development of races. Such understanding of Koidula's ancestry reflects the theory of degeneration widely known in Europe. Päivi Molarius refers to heated discussions in Finland at the turn of $19^{\text {th }}$ and the beginning of the $20^{\text {th }}$ century on the development 
possibilities of the Finnish race, which contained a fear of developing in the wrong direction, and an emphasis on a belief of the weakening of the Western people that could be perceived in the increasing immorality and flourishing of mental disorders in the degenerating society $(2003,121)$.

The section of Kallas' biography of Koidula that focuses on blood heritage seems to support the author's belief in the strength and potential of a young race, stemming from country life that she has also emphasized in her other works. Paradoxically however, Kallas links Koidula's talent with the same sickly blood, clearly stating that the race heritage from her paternal family could never have made Koidula the symbol of Estonian national awakening, "the substance from the Jannsen's side would hardly have been sufficient for lighting these heroic sparks that blazed in Koidula's heart during her short period of blossoming"53 $(1915,31)$. In other words, Kallas believes that Estonian blood is not capable of producing the geniuses of Estonian culture; for such achievements it is necessary to involve the blood heritage of longer and older European cultural traditions, even if it comes from a family with "indisputable markers of degeneration" 54 (Kallas 1915, 30).

In her consideration of Koidula's racial heritage, Kallas ties together her talent and degeneration, a link that clearly points to Cesare Lombroso's paradigm of the genius. Kallas' diary indicates that at the time of writing Koidula's biography, Lombroso's work was not unknown to her; on 8 February 1911 she writes in her diary: "I read Lombroso and, in my mind, reduce the dimensions of the world and its people" 55 (Kallas 1953, 221). The figure of Koidula is, in fact, quite an exact application of Lombroso's theory of the genius. I have already pointed out that Lombroso did not aim at celebrating neurasthenia or other degenerative features relating to the genius; rather, he wanted to show that the characteristics of the genius and degeneration, especially different forms of insanity, are separated by an extremely thin boundary. Lombroso's theory was often applied in reverse and Kallas' treatment of Koidula is a good illustration of such approach. Paradoxically, the firmest proof of Koidula's genius is the already-degenerating blood that is flowing in her veins, which explains her "heightened feelings, passionate commitment and lyrical inspiration" ${ }^{56}$ that are revealed in more sickly forms in other members of her family (Kallas 1915, 32). Such understanding of the genius would have been difficult to envision in relation to races with a short history of high culture, as the Estonian and Finnish race undoubtedly were by any other race theories of the time.

Koidula's biography contains yet another interesting possible reference to Lombroso. Kallas examines Koidula as a symbol of the Estonians' spiritual life, as "a shooting star whose already forgotten path is outside the line of vision of many people" $57(1915,17)$. The concept a shooting star is central to Kallas' interpretation of Koidula's life, as the choice of this word for the title of the biography already indicates. As a trope, shooting star runs through the opening chapter of the biography in many variations, highlighting its different connotations. While on the one hand, it focuses attention on Koidula's sudden and very intense rise to prominence as a central figure of Estonian national awakening movement, on the other, such a characterization also emphasizes the very brief duration of such position. "A shoot- 
ing star" is the exact expression that Lombroso uses to describe the genius, stating that a s/he does not resemble "a planet that circles on its steady orbit but a shooting star that flashes for a moment and extinguishes rapidly when falling to the Earth" $(1896,361)$. Such a formulation was part of Lombroso's criticism of the genius as an (overly) highly valued phenomenon in culture; in reverse form, it becomes for Kallas a marker of Koidula's genius. Furthermore, in Koidula's portrait, Kallas weaves together Lombroso's conceptualisation of genius with features that are specifically characteristic of the "Northern spirit". Kallas does not consider Koidula much of a talent as a poet or a writer, as she emphasizes already in the foreword of the biography that Koidula's importance as a writer "is more or less of a local kind" ${ }^{8}$ (Kallas 1915, 16). The greatness (and genius) of Koidula lays in her "inspiring personal influence on her contemporaries" 59 (Kallas 1915, 16), her ability for intense enthusiasm, and a capacity for inspiring others. In other words, Koidula's character has an ecstatic quality characteristic of the northern spirit as outlined by Luiga that is closely related to ecstasy and magic (see Luiga 1995, 204-209). ${ }^{60}$

\section{Conclusion}

The interest of Aino Kallas in the problems of race and heredity can, on the one hand, be related to her own life. Kallas envisioned her identity via her multiply talented paternal family, imbued with a sense of restlessness and wanderlust, bringing together the properties of several different cultures and races, thus creating a hereditary pattern where she could easily fit the trajectory of her own life. Her discussion of the potential and limitations of the Estonian people or race could at least partly have been triggered by her wish to demonstrate that her marriage to an Estonian was not a step downwards on the cultural ladder, as she had been told during her engagement by her brother-in-law. By saying that, he may have had expressed not only his own personal opinion but also represented an opinion circling in Finland of the so-called "older brother's self-confident superiority" ${ }^{61}$ (Olesk 2005, 39).

On the other hand, heated discussions on the subject of race were going on in Europe and in the Scandinavian countries in the late $19^{\text {th }}$ and early $20^{\text {th }}$ centuries. The complexity of Aino Kallas' engagement with the question of race and its diverse forms of manifestation in her work indicates the depth of her knowledge on the subject concerning different cultural spaces. Her focus on the subject of race and her examination of her own heritage and identity and her varied contemplations of the possibilities and limitations of the Estonian race variation in relation to different race theories underline's Aino Kallas' existence as a "modern individual." On a more general plane, however, her engagement with the thematics of race is also a marker of the degree of modernity of Finnish and Estonian culture of the early $20^{\text {th }}$ century, of wide familiarity with theories and subjects that were topical in Europe, and of their insightful application and reformulation in the analysis of their own culture. 


\section{Notes}

1. The article has been written with the support of ESF grants 7354 ("Positioning Life-Writing on Estonian Literary Landscapes") and 7271 (“Writing Women': Women in Estonian literary and cultural history 1880-1925").

2. [Niin että jos nyt voisin vapaasti valita, en enää pyytäisi itselleni juuria en Suomessa enkä Virossa, vaan siinä suuressa ihmisyydessä, johonka me jokainen voimme juurtua ja siinä kasvaa.]

3. [Meidän kaikkien juuremmehan ovat syvällä menneisyydessä; ymmärtääksemme itsemme täytyy meidän tuntea ne, joista polveudumme.]

4. See Laitinen 1997, 166; also Kurvet-Käosaar 2007, 211-234, and Lappalainen $1995,168-188$.

5. [(Isa) kaudu põlven ma liikumishimulisest suguvõsast ... kellesse on segunenud abielude kaudu mõne sugupõlve kestes kaheteistkümne eri rahvuse veri. ... läbi kogu oma elu olen tunnud sügavalt seda seguvere mõju oma arenemises, üheltpoolt takistavana ja hajutavana, teiseltpoolt jälle tarviliku kunstilise tõukejõuna.] It is noteworthy that Aino Kallas affiliates herself only with the diverse heritage of the paternal side of her family, almost completely bypassing the no less gifted maternal side (see, e.g., Kallas 1953, 64-70, 1952, 251-253, 1945, 247). The childhood summers spent at Kiiskilä form the core of Aino Kallas' exposure to the paternal side of her family. After the deaths of her father in 1888 and her paternal grandmother in 1889 and the selling of the Kiiskilä manor, wider contacts withered and were re-established in the 1910s when Katinka Rabe was conceived. Aino Kallas remained close with her half-siblings from her father's first marriage, in particular with Helmi Setälä and Kaarle Krohn throughout her life. The influence of the maternal side of her family, in particular close contact with her aunt Ida Godenhjelm and her husband Frederik, on the formative years of Aino Kallas cannot be underestimated. Aino Kallas herself, however, has repeatedly emphasized scant or almost non-existent ties with "maternal inheritance" (Kallas 1945, 247). More than intellectual capacities or the cultural milieu, the hereditary factor from which Aino Kallas wishes to distance herself is general disposition or temperament. In her diary, she describes her mother as "one of life's orphans who are as if destined to suffer and to settle for half of what others get" [niitä elämän lapsipuolia, jotka ovat kuin luodut kärsimään ja tyytymään puoleen siitä, mitä muut saavat] (Kallas 1952, 252). Even more problematic was her mother's "partial mental confusion, extreme melancholy and excruciating delusions" [osittaista mielenhäiriötä, äärimmäistä raskasmielisyyttä ja kiduttavaa luulosairautta](Kallas 1952, 251) despite the fact that she was well aware also of her father's incidents of temporary insanity (Kallas 1953, 70) that she also touches upon in Katika Rabe. Aino Kallas valued vitality and motility and related with unease to her mother's quiet and subdued disposition and her slow "fading out" over the years. See also KurvetKäosaar 2006b, 20-24; Laitinen 1997, 31-34; Leskelä-Kärki 2006, 292-331.

6. Maarit Leskelä-Kärki has researched these issues extensively (see Leskelä-Kärki 2006, 292-331).

7. [... alkuperäisen talonpoikaisveren voima.]

8. [Ja ihminen, joka sen tekee, sortuu aina, hänen persoonallisuutensa ei voi pysyä eheänä.]

9. [Ja virolaiset, mitä ne ovat? Kuolevaa kansaa ...Sillä jos te niistä tahdotte virolaisia, niin saatte kasvattaa ne suoraan talonpojiksi tai käsityöläisiksi, virolaista sivistystä ei ole olemassa.]

10. The initial source of the recognition of the value of folk culture, as well as its relation with a quest for national identity, can certainly be traced back to Aino Kallas' father, Julius Krohn, an important figure of Finnish national awakening, as well as his folklorist half-brother Kaarle Krohn. 
11. Earlier distinctions of different races include, e.g., Systema naturae (1735) by Karl Linné and De generis humani varietate (1795) by Johann Friedrich Blumenbach. For other considerations of the hiearchy of races from the second half of the 19th century, see e.g., Allgemeine Kulturgeschichte der Menschheit (10 vol., 1843-52) by Gustav Klemm, L'Aryen et son rôle social (1899) by Georges Vacher de Lapouge, Natürliche Auslese beim Menschen (1893) by Otto Ammon, Grundlagen des Neunzehnten Jahrhunderts (1899) by Houston Stewart Chamberlain, Primitive Culture (1871) by Edward Tylor.

12. [...hävittävien sotien tantereeksi.]

13. For Taine's influence on Kallas, in particular with regard to her evaluation of the Young Estonia movement, see Hinrikus in the current volume.

14. Other well-known considerations of this issue include, e.g., Max Nordau's Entartung (1892) and Cesare Lombroso's work on degeneration and criminality of man, as well as Oswald Spengler's Der Untergang des Abendlandes (1918-22).

15. Examples of the theme of degeneration in Finnish literature include, e.g., Johannes Linnankoski’s Laulu tulipunaseista kukasta [Song of the Scarlet Flower] (1905), Maila Talvio’s Silmä yössa [An Eye in the Night] (1907) ja Tähtien alla [Under the Starry Skies] (1910); it can also be traced in the work of L. Onerva, Eino Leino and Arvid Järnefelt.

16. See, e.g., Eduard Vilde’s Mäeküla piimamees [The Milkman of Mäeküla] (1916); in different vein, also the student novellas of A. H. Tammsaare in collections Pikad sammud [Long Steps] (1908), Noored hinged [Young Souls] (1909), Üle piiri [Across the Border] (1910), Kärbes [The Fly] (1917), and his novel Kõrboja peremees [Master of Kõrboja] (1922). August Kitzberg's play Libahunt [The Werewolf] (1912) that focuses on the subject of familiar and alien blood, Eduard Vilde's dramas Tabamata ime [The Inscrutable Mystery] (1912) and Pisuhänd [The Hobgoblin] (1913) that deal with social climbing as the spoiling of race and interrelations between the environment and race are also of importance here.

17. [See on kui mingi üleüldine kängu-jäämine, kehaline, kõlbline ja vaimline ebatäius.]

18. In addition, Lombroso provides a substantial list of other features of the man of genius pointing to degeneration, such as, for example, "excessive asymmetry of face and head ... sexual precocity, smallness or disproportion of the body, left handedness, stammering, rickets, phthisis, excessive fecundity" $(1896,6)$.

19. [En ole koskaan halunnut olla muuta kuin nainen, mutta kadehdin miehiä niitten muutamain aivoainegrammojen takia, joita heillä on enemmän.] See also KurvetKäosaar 2006b, 39-40, 2006a, 105-106.

20. On the treatment of race problems in the Estonia of the early 20th century, see Karjahärm and Sirk 1997, 284-297.

21. [rahvusetunde algelementidega, ürgollustega.]

22. [Silmas pidades seda kogu, mis eestlased vaimse jõu poolest aastasadade kestes on jõudnud anda, esite Balti saksakeelsele seltskonnale, siis vähesel mõõdul Venemaale ja kõige enam Eesti oma hariduse töö tegemiseks, siis peab eestlaste tõulist väärtust ikkagi õige kõrgelt hindama.]

23. [... virolaisen hermoherkän taipumuksen olemassaoloa.]

24. [On kuin vuosisatoja orjuudella rasitetun kansan säikkynyt fantasia olisi ehdoin tahdoin kaikkialta etsinyt kauhun ja ahdistuksen aihetta].

25. See Laitinen 1997, 61-64 and Molarius 2003, 130 for an analysis of Ants Raudjalg in this vein.

26. [Mitä meistä tulee? Lantaa Venäjän loppumattomille pelloille.]

27. [Koti ei ollut entisellään. Isä oli vanhentunut ja murtunut.]

28. [Toisia on tuleva, meitä voimakkaampia, meitä vaatimattomampia, epä-itsekkäämpiä, jotka eivät hellitä kotoiseista maaperästä ...vaan jättävät jälkeläisilleen elonkorjuujuhlat ja karkelot kypsät rypäleet hiuksissa.] 
29. [...toiminnan äkillisyys ...voimakkaan, hetkellisen vaiston valtaote ...eräänlainen esiintymishalu, yleisön- ja ihailun tarve.] The list of such characteristics in Koidula's biography is related to the context Kallas uses to describe Möldri-Mats, one of Koidula's paternal forefathers, narrating two anecdotes that had survived of that man. One is about how he had dragged a large stone across the river of Veskijõgi, and the second about how he had rushed into the river to save a drowning man and had lost his own life there too.

30. [Tässä talonpojassa ... suoristui seitsensatavuotisen orjuuden selkä.]

31. [Hiljaa, hitaasti vuotaa virolainen voima hänestä vierasrotuiseen lapseen... jonka veri sukupolvien kuluessa on vaalentunut.]

32. [Katkeamattomat ovat ne siteet, jotka yhdistävät minut Oskariin. Kaikki, mikä minussa on tervettä, iloista, luonnollista ihmistä, ikävöi häntä.]

33. [Oskarin valitsin kerran nuoruuteni rotuvaistolla, tulevien lasteni tähden, mahdollisimman terveen miehen, henkisesti ja ruumiillisesti. Hänet, sen toisen, olen valinnut yksilöna, itseäni varten, koko herkistyneen, monimutkaiseksi ja sokkeloiseksi muodostuneen henkisen elimistöni vaistolla.]

34. [Virolainen psykiatri Juhan Luiga väitti kerran, että Oskar Kallasen sekä henkinen että ruumiillinen olemus hipoi niin läheltä normaali-ihmisen perikuvaa kuin suinkin mahdollista. Juhan Luigan, kyynikon ja epäilijän lausumana ...tämantapainen määritelmä ...sulki jo sinänsä pois varsinaisen nerouden, joka saman katsantokannan mukaan on useissa ilmaisumuodoissaan sairaalloinen, patologinen poikkeuisilmiö.]

35. [Oskar Kallasen perusominaisuudet ja sielunkyvyt ... olivat, sanoisinko, yhteisymmärryksessä, sovinnossa keskenään suurempien ristiriitojen siten välttyessä.]

36. [Hänen suonissaan kiersi kauttaaltaan virolaista verta, sekä isän että äidin taholta, siis rotupuhtaudeltaan täysin sekoittumatonta.]

37. [Ihmisen jälki! Maailma ei ollutkaan autio....Ja ... ylpeä, jalosukuinen Gerdruta Carponai nyt kumartui ja ... suuteli nöyrästi tätä tuntemattoman jalan jälkeä hiekassa.]

38. ["Minä olen Laes, - Kadariku-Laes, - tuosta mökistä".]

39. [Ei ollut enää vapaita eikä epävapaita, saksalaisia eikä maarahvasta, ei säätyja eikä luokkia.]

40. [Ja heidän rajussa syleilyssään olkivuoteella, kalastajapirtin nokisessa hämärässä, hehkui heidän kuolemanpelkonsa ja tulevien sukupolvien elämänhalu.\}

41. [Gerdruta Carponai katosi ihmisten ilmoilta kuin suohautaan kivi, hävisi iäkseen miehensä alhaiseen säätyyn, vieraan heimon keskuuteen, sukunsa, säätyläistensä hylkäämänä. Hänen lapsensa olivat kalastajia ja orjia.]

42. [raikkain ja puhdasverisin saarelaistyttö.]

43. [...ja tukka musta kuin terva, ruumiiltaan ruskea, ja siniset ankkurinkuvat käsivarsissa.]

44. [Mutta yhdeksän kuukautta hänen lähtönsä jälkeen toi Treili-Reet ilmoille pojan, jolla oli musta tukka ja ruskea iho.]

45. [Merimiehinä he ovat saaren parhaita, meressä heti lapsesta lähtien kuten vesilinnun pojat.]

46. [Ja niin tuli valkoverisestä Treiali-Reetasta kanta-äiti tummalle suvulle, jolla oli rohkeampi ja polttavampi poljento verissään, kaukaisten vesien ja seikkailujen ikäva.]

47. [Selle kaudu tulnud võõras veri on võinud võrdlemisi sporaadiliselt esialgse tõu omadusi moonutada, ja seegi moonutus, ainult ajuti võimalik, on pidanud ajajooksul tõu enese poolt sündiva puhastuse kaudu hävitatama ja välja lahutatama, kui see assimileeritav ja ühte liidetav ei ole olnud.]

48. Katinka's assessment of the son of the tenant's son, Kuninga Aadu, and Katinka's night trip to a meadow called Soldat-Niit, can be interpreted this way.

49. [... piirteitä, jotka tapaamme uudestaan Mats-myllärin pojanpojantyttäressä.] 
50. [... tuo hän, käsityöläisen, kankurin tytär, liikkuvamman ja keveämmän aineksen, todenperäisesti myös sanataituruuden lahjan.]

51. [... herkeäkielisestä ja heleäsävyisestä kankurintyttärestä.]

52. [Hänen kauttaan sekaantui Mats-myllärin voimakkaaseen ja Malle Kuldkeppin valoisaan vereen "vieras veri", kivulloisia hermotiloja sairastavan, vierassyntyisen suvun. ...Ikäänkuin hajoittava aines se tunkeutuu ennen terveeseen elimistöön, kuin taudinitiö, jonka hävittävä vaikutus tuntuu heti jo seuraavassa polvessa.]

53. [Jannsenilainen aines olisi tuskin riittänyt sytyttämään sankarillista, palavaa kipinää, joka Koidulan sielussa lyhyen loistoaikansa hehkui.]

54. [suvun kieltämättömät rappeutumismerkit.]

55. [Minä - luen Lombrosoa ja kavennan ajatuksissani maailman ja ihmisten dimensiooneja.] Kallas had read Lombroso's treatment of the genius and probably also his works on the racial backgrounds of male and female criminals (see Laitinen 1997, 251; 626).

56. [Koidulan korostettu tunnevoima, hänen intohimoinen antaumiskykynsä, hänen lyyrillinen inspiratsionsa...]

57. [...hämäryydestä tullutta lentotähteä muistuttavana, joka hetkeksi piirtää kimmeltävän ratansa Viron harmaalle taivaalle...]

58. [...enemmän tai vähemmän paikallista laatua.]

59. [...hänen agitatorisesta, henkilökohtaisesta vaikutuksestaan aikalaisiinsa.]

60. Several scholars of Kallas have pointed out (Laitinen 1997, Leskelä-Kärki 2006) that Tähdenlento can be viewed as Aino Kallas' contemplation on the key problems of her own life of the period: those of identity and the feeling of rootlessness of living in a foreign country, difficulties in juggling the roles of a mother, wife and artist, but first of all, the question of how talented she herself was as a writer. This subject comes up again and again in her diaries, implying that Aino Kallas sensed her own creative potential, but was able to realise it in full (and to find satisfactory recognition) only later. Without doubt, her anxious and worried contemplations were influenced by strongly gendered theories of genius, most importantly by Weininger and Lombroso. The biography of Koidula can also be viewed as a passionate attempt to argue for the possibility of woman's genius, potentially including also herself.

61. ["suurema venna" enesekind[el] üleolek.]

\section{References}

\section{Research Objects}

Kallas, Aino 1959: Elämäntoveri. [Companion for Life.] Helsinki: Otava.

Kallas, Aino 1945: Kanssavaeltajia ja ohikulkijoita: muistoja ja muotokuvia. [Fellow travellers and by-passers. Memories and portraits.] Helsinki: Otava.

Kallas, Aino 1929: Kogutud teosed I. Mere tagant. Ants Raudjalg. [Collected Works I. Beyond the Sea. Ants Raudjalg.] Tartu: Eesti Kirjanduse Seltsi Kirjastus.

Kallas, Aino 1995: Lähtevien laivojen kaupunki. [The City of Leaving Ships.] Helsinki: Suomalaisen Kirjallisuuden Seura.

Kallas, Aino 1918: Nuori-Viro. Muotokuvia ja suuntaviivoja. [Young Estonia. Portraits and Trajectories.] Helsinki: Otava.

Kallas, Aino 1952: Päivakirja vuosilta 1897-1906. [Diary from the Years 1907-1915.] 
Helsinki: Otava.

Kallas, Aino 1953: Päivakirja vuosilta 1907-1915. [Diary from the Years 1907-1915.] Helsinki: Otava.

Kallas, Aino 1954: Päivakirja vuosilta 1916-1921. [Diary from the Years 1916-1921.] Helsinki: Otava.

Kallas, Aino 1915: Tähdenlento. Virolaisen runoilijattaren Koidulan elämä. [Shooting star. Life Story of the Estonian poetess Koidula.] Helsinki: Otava.

Kallas, Aino 1957: Valitut teokset. [Selected Works.] Helsinki: Otava.

\section{Research literature}

Aavik, Johannes 1988: Rahvustunde nõrkusest Eestis. [On the weakness of national sentiment in Estonia.] Tallinn: Loomingu Raamatukogu.

Arata, Stephen 1996: Fictions of Loss in the Victorian Fin de Siécle. Cambridge: Cambridge University Press.

Biddiss, Michael 2003: Hippolyte Taine and the Making of History. In: N. Atkin and F. Tallett (eds,), The Right in France. From Revolution to Le Pen. London: I.B. Tauris.

Galton, Frances 1909: Essays in Eugenics. London, the Eugenics Education Society.

Gobineau, Arthur 1856: The Moral and Intellectual Diversity of Races. Philadelphia: J. P. Lippincott \& Co.

Karjahärm, Toomas and Sirk, Väino 1997: Eesti haritlaskonna kujunemine ja ideed 1850-1917. [The Development and Ideas of Estonian Intelligentia 1850-1917.] Tallinn: Eesti Entsüklopeediakirjastus.

Kurvet-Käosaar, Leena 2006: Aino Kallase haakumisi J. Randvere 'Ruthiga' moodsa naise kuju pinnalt. [The Notion of the Modern Woman in the Work of Aino Kallas and J. Randvere's "Ruth".] In: M. Hinrikus (ed), J. Randvere "Ruth" 19.-20. sajandi vahetuse kultuuris. [J. Randvere's "Ruth" in the Context of the Turn of the $19^{\text {th }}$ Century.] Tallinn: Underi ja Tuglase Kirjanduskeskus. (2006a)

Kurvet-Käosaar, Leena 2006: Embodied Subjectivity in the Diaries of Virginia Woolf, Aino Kallas and Anaïs Nin. Dissertationes Litterarum et contemplationis comparativae. Tartu: Tartu University Press. (2006b)

Kurvet-Käosaar, Leena 2007: Kunstniku portree väikese tüdrukuna. [Portrait of an Artist as a Young Girl.] - In: Arne Merilai (ed,), Looming - olemise kehtestamine: Viivi Luik. [Creation as a Declaration of Being: Viivi Luik.] Tartu: Tartu University Press.

Laitinen, Kai 1997: Aino Kallas. Uurimus Aino Kallase loomingu peateemadest ja taustast. [Aino Kallas. A Study on the Main Topics and Background of her Work.] Tallinn: Sinisukk.

Lappalainen, Päivi 1995: Tuoksuvat kukat ja kultaiset hedelmät. Aino

Kallaksen Katinka Rabe identiteetin rakentumisen kuvauksena. [Fragrant Flowers and Golden Fruits: Aino Kallas' Katinka Rabe as a Portrayal of the Construction of Identity.] In: K. Kurikka (ed.), Identiteettiongelmia suomalaisessa kirjallisuudessa. [Identity Issues in Finnish Literature.] Turku: Turun Yliopisto, Taiteiden tutkimuksen laitos.

Leskelä-Kärki, Maarit 2006: Kirjoittaen maailmassa. Krohnin sisaret ja kirjallinen elämä. [The Krohn sisters: Lives in writing.] Helsinki: Suomalaisen Kirjallisuuden Seura.

Lombroso, Cesare 1896: The Man of Genius. London: Charles Scribner's Sons.

Luiga, Juhan 1995: Põhjavaim. [The Northern Spirit.] In: Mäss ja meelehaigus. [Revolt and Mental Illness.] Tartu: Ilmamaa.

Molarius, Päivi 2003. Will the Human Race Degenerate? In: P. Lyytikäinen (ed.), Changing Scenes. Encounters between European and Finnish Fin de Siècle. Helsinki: Suomalaisen Kirjallisuuden Seura. 
Moore, Gregory 2002: Nietzsche, Biology and Metaphor. Cambridge: Cambridge Univeristy Press.

Olesk, Sirje 2005: Uus põlvkond hõimutöös. [New Generation of Kinship Advancement.] In: Kultuurisild üle Soome lahe. Eesti-Soome akadeemilised ja kultuurisuhted. [Cultural Bridge Across the Gulf of Finland. Academic and Cultural Ties between Estonia and Finland.] Tartu: Eesti Kirjandusmuuseum.

Pearson, Karl 1905: National Life from the Standpoint of Science. London. Adam and Charles Black.

Pick, Daniel 1989: Faces of Degeneration. An European Disorder, c. 1848- c.1918. Cambridge: Cambridge University Press.

Rafter, Nicole Hahn and Gibson, Mary 2004: Editor’s Introduction. In: Nicole Hahn Rafter and Mary Gibson (eds), Cesare Lombroso and Guglielmo Ferrero. Criminal Woman, the Prostitute and the Normal Woman. Durham: Duke University Press.

Ridala, Villem 1913: Tõu küsimus. [The Question of Race.] In: V. Reiman (ed.), Eesti Kultura III. [Estonian Culture III.] Tartu: Postimees.

Rojola, Lea 1999: Veren ääni. [The Voice of the Blood.] In: L. Rojola (ed.), Suomen kirjallisuushistoria 2. Järkiuskosta vaistojen kapinaan. [Finnish Literary History II: From Belief in the Mind to a Rebellion of Insticts] Helsinki: Suomalaisen Kirjallisuuden Seura.

Taine, Hippolyte A. 1890: History of English Literature. Volume I. London: Chatto \& Windus. 


\section{Following the Traces of Unknown Bathseba}

\section{Introduction}

Among the widest-known Biblical love stories is a triangle story between David (the second king of the kingdom of Israel), Bathsheba (a daughter of Eliam, a warrior in King David's army) and her spouse Uriah the Hittite, (a soldier in King David's army). King David sees Bathsheba for the very first time taking a bath on the roof of her house. David immediately desires beautiful Bathsheba, calls her to the King's castle and makes her pregnant. Trying to cover the evidence of the forbidden relationship, David summons Uriah home in the middle of the campaign, hoping Uriah would believe that Bathsheba's pregnancy has been caused by him. However, as a loyal soldier, Uriah repeatedly refuses to return. After numerous unsuccessful persuasions, David finally commands Uriah to the leading edge of battle. Consequently, Uriah dies in the battle and David takes Bathsheba as one of his wives. Nevertheless, Israel's God later punishes the crime by killing the firstborn of David and Bathsheba.

The story of Bathsheba has been varied several times in Western visual arts and literature. The tale and figure of Bathsheba, in particular the bath scene of the story, have been fascinated classical artists from Rembrandt to Bordone and Dürer. Fictitious extensions of the Bathsheba story include Der König David Bericht (The King David Report 1972) by a German-Jewish author Stefan Heymin; God Knows (1984) by American author Joseph Heller; and Bat Seba (1984) by Swedish author Torgny Lindgren.

In Finnish literature, the best-known version of the Bathsheba story was created by Volter Kilpi (1874-1939), whose first novel Bathseba. Daavidin puheluja itsensä kanssa [Batshseba. David's Monologues] was published in 1900. Kilpi's work was attractive in the contemporary field of Finnish literature, mainly because of its connections to the trends of symbolism in contemporary world literature. Afterwards, Kilpi's Bathseba has been described as a flag-bearer of Finnish new romanticism. Kilpi's story, however, essentially deviates from the original Biblical narrative. In Kilpi's Bathseba, the description of David's thoughts are at the centre of the story, and David himself has been described as a modern figure rather than a mythical hero. (Lyytikäinen 1995, vii, xi-xii.)

Aino Kallas was also inspired by the figure and story of Bathsheba at the turn of the $20^{\text {th }}$ century. In 1905, she published a short story called "Bath- 
seba Saarenmaalla", ["Bath-Sheba of Saarenmaa"] in which the composition of the biblical narrative is situated in Estonia in the middle of the $19^{\text {th }}$ century, during the period of serfdom. ${ }^{1}$ Nearly twenty-five years later, in 1932, Kallas also published a dramatic version with the same name. This drama nowadays is included as a central and well-known part of Kallas' oeuvre. For instance, Tauno Pylkkänen, a famous Finnish composer, wrote an operatic version of the play in 1940.

Moreover, Kallas also created a third version of the story of Bathsheba. This work - called simply Bathseba - was written during 1909 and 1910. It essentially differs from Kallas' two versions of Bath-Sheba of Saarenmaa. First, Bathseba was not situated in an Estonian context, but in a biblical milieu. Secondly, it is a play written in verse. Both of these features also make this play an exception among Kallas' works. Bathseba was never published. After having finished the manuscript, in 1910, Kallas asked for comments from a theatre critic and (nowadays poorly known) author Jalmari Hahl (1869-1929). His critique towards the play was highly negative: Hahl considered the characters of the play implausible, and the biblical theme of the play old-fashioned. According to him, the verse of the play was awkward, and the motifs and diction in places anachronistic. Finally, Hahl also doubted the author's abilities as a dramatist.

Kallas copied Hahl's answer in her (later published) journal. According to this journal, Kallas planned to rewrite the play. Apparently, this never happened. Years later, in a letter to Aino Kallas researcher Kai Laitinen (20.3.1953), she wrote that she had later lost the whole manuscript. In later research, then, Bathseba was supposed to be totally lost. (Laitinen 1973, 163, 267; 1995, 341.)

In 2008, I visited the Estonian Literary Museum in Tartu, in search of material for my doctoral dissertation. In the archive collections of Aino Kallas, surprisingly, I found a manuscript called Bathseba. Runonäytelmä viidessä näytöksessä [Bathseba. A poetic drama in five scenes] which was written in Tartu and Elva in 1909. There are several reasons to suppose, that the manuscript is the one on which Jalmari Hahl commented in 1910. First, the content of the play is very similar to Hahl's description of the play in his letter. Secondly, there are some smaller details that support this assumption. For instance, the words suihkukaivo [a fountain] and ruokalista [menu] have been underlined in the manuscript. In turn, in his letter in 1910, Hahl writes to Kallas the following: "At times, your play has too modern features. [...] 'Fountains', 'menus', etc. do not feel like ancient Hebrew." ${ }^{2}$ (Jalmari Hahl's letter to Aino Kallas 19.11.1910, FLS LitA.) In the manuscript, Hahl also comments on these words by writing: "Modern!" and "It seems a bit modern: menu" 3 .

In this article, I will analyse the unknown Bathseba as a part of Aino Kallas' oeuvre in the context of literature of its own age. I will also consider its evaluation as a contemporary reader and a literature researcher. Is it unsuccessful, as Jalmari Hahl suggested? Moreover, I will also determine some reasons why Bathseba got lost and why it had not been found until the Spring 2008. 


\section{The process of writing Bathseba}

Aino Kallas' journals (published in 1952-1956) give detailed information about the writing process of Bathseba. According to the journal notes, Kallas had the very first idea of this play in the Spring of 1909, when she was on a long trip to Europe. The author's expectations for this work were great - and the notes in the journals strongly support her intentions.

I was wandering in the mountains, thinking of Bathseba. Is this how my creative powers will finally be released? (Aino Kallas' journal 1.5.1909, FLS LitA.)

I am constantly thinking of Bathseba (Aino Kallas' journal 11.5.1909, FLS LitA.)

Bathseba is still like an empty bowl. Nevertheless, I believe the whole content of mine is going to fit in it. (Aino Kallas' journal 17.5.1909, FLS LitA.) ${ }^{4}$

Nevertheless, writing Bathseba was not straightforward. At first, Kallas tried to write the play in prose, then in verse. Also the number of the scenes varied between three and five. Moreover, the number of characters varied several times. Even though the author herself was clearly enthusiastic about this work, she also, according to the journals, felt uncertain:

A couple of days still, and Bathseba will be finished - as a draft, naturally, but as a perfect draft. I trust and doubt in turns - Bathseba, namely." (Aino Kallas' journal 12.11.1909, FLS LitA.)

Who has written Bathseba - me or someone else! And what worth is Bathseba? (Aino Kallas' journal 4.12.1909, FLS LitA.) ${ }^{5}$

As mentioned before, the manuscript was not completed until the autumn of 1910. Thus, Kallas wrote Bathseba in about one and a half years. Meanwhile, she did not publish any works of fiction. In fact, the period between 1907 and 1913 (that is to say, between the novel Ants Raudjalg and a short story collection Lähtevien laivojen kaupunki, [The City of Departing Ships] is often described as "a silent period" in Kallas' literary career. Nevertheless, it was not an infertile period. During this period, in 1911, Kallas published two translations (Virolaisia kansansatuja, [Estonian Folk Tales], and Merentakaisia lauluja, [Songs From Behind the Sea]. At the same time of writing Bathseba, she also became interested of works by Goethe (for a closer analysis, see Liina Lukas' article in this anthology). Moreover, the unpublished Bathseba was also an outcome of Kallas' "silent period". The writing process of Bathseba influenced to her subsequent works, too, as will be indicated later in this article.

Bathseba is situated in ancient Jerusalem, during the era of King David. The play refers to numerous events in the Books of Samuel. In the play, for example, there is mention of the fight between David and Goliath, of the childlessness of David's wife Michal, and of the connection between David and Jonathan. The main characters are also partly based on the Old Testament (King David, Uriah, Bathsheba, Michal and Mephiboseth, a servant of King David). The author, however, creates other characters herself, the most 
essential of which is a central character Ketura, the mother of Uriah and mother-of-law of Bathsheba). The name Ketura, however, is the name of another Biblical character, namely one wife of Abraham (1. Gen. 25: 1). ${ }^{6}$

The five-scene plot of the play can be summarised as follows: the first scene is situated on the roof of the castle of King David. Mephi-Boseth and Micha meet first. Then Micha leaves. Mephi-Boseth and King David have a conversation on the roof of the castle. The king has fallen in love with the beautiful and strange Bathseba. Mephi-Boseth persuades David to send Uria to arms and, meanwhile, takes Bathseba to the castle. The second scene takes place in the yard of the house of Uria and Bathseba. Ketura, Uria's mother, is unsatisfied with her daughter-in-law, who, according to Ketura, is lazy and careless. The quarrel between the women is interrupted, when the shopkeeper Jesbek arrives. According to Jesbek, the messenger of King David had visited and asked questions about Uria. Bathseba takes this as a bad omen. Afterwards, King David comes to the yard, wearing a disguise. Bathseba, however, recognises the visitor as the King of Jerusalem. David confesses his feelings to Bathseba and asks her to meet with him later in the garden of his castle. After the secret visit with King David, Uria comes home unexpectedly. The king has ordered him to war. Ketura and Bathseba beg him to stay home, but Uria does not listen to them. The events of the third scene take place in the garden of the king's castle. Bathseba has moved to the castle but feels guilty. The king's servant, Mephi-Boseth, meets her in secret and says that Uria may be in danger. Bathseba also meets Jesbek, who tells her of the hatred Ketura feels towards her daughter-in-law. At the end of the third scene, Bathseba takes off her royal clothes and jewelry and runs away.

The stage of the fourth scene is the king's castle. The main events of this scene are, more clearly than other events of the play, based on the events of the second Book of Samuel. In the play King David meets Nathan the prophet, who tells him a parable that is identical with the Biblical account of the poor man's only lamb story. This episode is found in the Old Testament (2. Sam. 1-14). The episode ends with Nathan asking David to send Bathseba home, but the king refuses. Uria arrives to the castle, bringing a message to the king. Meanwhile, Mephi-Boseth tells the king that Bathseba has run away. The king becomes furious and writes a letter, in which he commands Uria to the front lines. This episode is also comparable with the events of the 2 nd Book of Samuel (2. Sam. 14-27). The events of the last scene of the play are, again, placed in the yard of the Uria's house. The troops of Israel have won the war. Ketura and the maids of Israel are making preparations to celebrate the triumph. Nevertheless, a young Israeli soldier comes to them and reports the death of Uria. He also reveals that Uria was fighting in the lead, commanded by the king. Surprisingly, Bathseba arrives at the house of Uria, after wandering for days in the wilderness. She regrets the relationship with King David and wants to stay home. Ketura reveals the death of Uria, which, according to her, is Bathseba's fault. Finally, King David comes to the yard of Uria. Bathseba talks to him about the death of Uria and her role in the events. David confesses his crime and begs Bathseba to stay with him. Nevertheless, Bathseba escapes and commits suicide. That is the conclusion of the play. 


\section{Bathseba as a literary work of its own age}

As pointed out before, in his crushing critique, Jalmari Hahl suspected that readers of the time would find the Biblical themes of Bathseba already outdated. A contemporary reader can, indeed, find this part of Hahl's critique understandable: Biblical themes were popular in Finnish literature at the turn of the $20^{\text {th }}$ century, particularly in works of drama and lyrics (Riikonen 2003: 107). In particular, Hahl mentions Volter Kilpi's Bathseba and the great attention it had evoked only a few years earlier:

Your subject is particularly demanding, while before your work, and quite recently, this subject has been treated by another Finnish author, that is to say, Volter Kilpi. Kilpi's work certainly is a novel, but, at any rate, it evoked remarkable attention. (Jalmari Hahl's letter to Aino Kallas 19.11.1910, FLS LitA.) ${ }^{7}$

Notably, while writing her own version of the story of Bathseba, Kallas also mentions Kilpi's work in her journals. In November 1909, she writes: "I would like to read Volter Kilpi's Bathseba. Previously, I have read only the beginning of the story. I don't know, if knowledge of Kilpi's work will interrupt my work or not." (Aino Kallas' journal 27.11.1909, FLS LitA.) ${ }^{8}$

The turn of the $20^{\text {th }}$ century is known as a Symbolistic period in Finnish literature. In fact, Kilpi's Bathseba is one of the best-known representations of Finnish literary symbolism. But what kind of relationship is there between Finnish literary symbolism and Kallas' unpublished Bathseba? Works of symbolistic arts widely refer to well-known Western myths. In Finnish symbolism at the turn of the $20^{\text {th }}$ century, references to biblical and classical myths were also common. A third famous source of arts of this era was stories the Kalevala. (See, e.g., Lyytikäinen 1997, 10.) In Kallas' oeuvre, the unpublished Bathseba is the only work that is situated in a Biblical milieu and time frame. Bathseba can be described as a straight extension of a well-known Biblical myth. As such, it clearly is an exception in Kallas' oeuvre.

Symbolistic themes had, however, become rarer in Finnish literature during the time of the writing of Bathseba (1909 and 1910). Nevertheless, the themes, motifs and symbols of the $20^{\text {th }}$ century Finnish symbolism appear throughout Kallas' works, even decades later. In particular, Aino Kallas' later lyrics bear many traces of early Finnish symbolism, even the ones written in the 1930s and 1940s. In Bathseba, there are some particular literary motifs, which can be viewed in the context of Finnish symbolism. Next, I will investigate two specific motifs: a flower and a well.

The motif of a flower is, in particular, connected to the main character Bathseba. Uria, as a loving but gullible husband, describes her as "a blue flower of mine", which is a conventional symbol of romanticism, first created by Novalis. It traditionally reflects something totally unachievable but, at the same time, enthusiastically desired. The flower is also connected to the figure of Bathseba in more implicit ways. For instance, when King David asks why Uria unconditionally trusts Bathseba, he answers that he certainly distinguishes a flower from a fruit. King David himself describes his forbid- 
den feelings - love and hatred - with a metaphor of a poisonous flower. "Is it now a poisonous flower that blossoms? / Long has its seed burgeoned in my soul / carefully shrouded, so that / I did not know it myself..." (Kallas 1909, 62, ELM LitA.) $)^{9}$ The intriguing symbolism of a flower in Kallas' Bathseba can also be compared with the symbolism in Volter Kilpi's Bathseba. In Kilpi's work, a flower symbolises human existence in its various dimensions. A blue flower symbolizes dreams and hopes, a red flower love, a yellow flower fulfilment and a black flower death.

A motif of a well, however, is the most repetitive motif - even a leitmotif - in Aino Kallas' Bathseba. First, it foreshadows the upcoming events in the play. In the second scene of the play, Bathseba breaks a pot lifting water from the well. Ketura interprets this as an omen of misfortune. Moreover, many meaningful events in the play are staged around the well. For example, Bathseba meets King David for the very first time at the well. In the third scene, at the gardens of the king's castle, Bathseba stands in front of a fountain, bitterly regretting running away from home. She decides to leave the royal life. After leaving the castle, she still regrets her betrayal and says that she is looking for a deep well to wash her sins away. Furthermore, at the very end of the play, she kills herself by jumping in the well at Uria's house. This recurring motif of a well can also be connected with a larger motif and the symbol of water. Water (for example, a lake, a sea or a stream) was a common symbol of the human mind in the poetics of symbolism. The surface of water conventionally reflected the consciousness of the human mind, depths of water, for one's part, the unconscious. (Lyytikäinen 1997, 67.)

In Kallas' Bathseba, an underground current reflects the ambivalent personality of one of the main characters of the play, King David. After giving the letter to Uria, David utters following words:

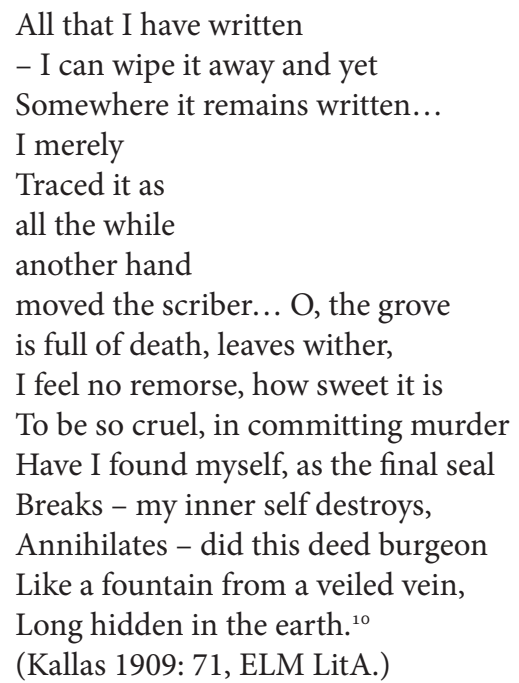

The interplay between the conscious and unconscious mind was a popular theme in early $20^{\text {th }}$ century literature. In Bathseba, the figure of King David is an ambivalent character in other ways. For David, his passionate love 
towards Bathseba and his murderous hatred towards Uria are equal. His servant Mephi-Boseth notes this in the following words:

O, great David,

A set of twins grown together

One an ill-fated twist of nature

A dreadful game, a cruel aberration,

And the other perfection itself, come

Down from Heaven as the Sun.

Only their blood flows united,

They share a source of warmth,

Food nourishes one and all,

Both feel every single move

Both feel touch, never apart

Never free of one another...

(...)

Suddenly David is born, in your soul

Love, murderous desire... ${ }^{11}$

(Kallas 1909: 18, ELM LitA.)

As mentioned, at the turn of the $20^{\text {th }}$ century Bible-based fiction was published abundantly in Finnish literature. Some of these works were very ambitious forays, which often imitated international paragons (Riikonen 2003, 107). Nevertheless, only a few remain classics except for - first and foremost - Volter Kilpi's Bathseba. Instead, much of The Bible-based fiction of this era in Finnish literature is nowadays more or less forgotten - such as the Biblical plays Jeftan tytär [Jefta's Daughter] and Simson ja Delila [Samson and Delilah] (1911) by Johannes Linnankoski. However, Aino Kallas' aspiration to create a fictitious extension of the story of Bathsheba reflects her connections to the contemporary field of Finnish literature. In fact, during the writing process of Bathseba, she also planned to write an extension of the myth of Samson and Delilah, as her journal notes indicate (Aino Kallas' journal 5.4.1910, FLS LitA). Kallas' effort to create fiction characteristic of the Finnish literature of the era is remarkable, because, in Finnish literary history, she has often been considered as a deviant author among the other authors and literary currents of the time.

\section{Bathseba in Aino Kallas' oeuvre}

Bathseba was written during a so-called silent period of Aino Kallas' oeuvre. This period - starting in 1907 and ending in 1913 - has also been described as a turning point in her oeuvre. According to previous research, the collections of short stories Meren takaa I [From Beyond the Sea I] and Meren takaa II [From Beyond the Sea II] (1904 and 1905) and the novel Ants Raudjalg (1907) represent the so-called Estonian realism of Aino Kallas, while a collection of short stories The City of Departing Ships (1913) themes of symbolism and impressionism of the contemporary literary pe- 
riod. (Laitinen 1973, 161-168, 180-242.) In her journals, the author herself describes the years between 1907 and 1913 as: "years of a literary crisis" and "long silent years" (Aino Kallas' journals 19.12.1908 and 11.4.1913 FLS LitA).

Bathseba is an exception in Kallas' ouevre not only because it is the only one of her works with a Biblical milieu, but also for other reasons. After 1902, the great majority of Kallas' works is situated in an Estonian context. Bathseba is also the only Kallas' play, which is written in verse. Altogether, Kallas published five plays: Bat-Sheba of Saarenmaa (1932); Mare ja hänen poikansa [Mare and Her Son] (1935); Talonpojan kunnia (1936) [Peasant's Honour]; Sudenmorsian [The Wolf's Bride] (1937) and Mallen tunnustukset [Malle's Confessions] (1945). Only the latest, a burlesque play Malle's Confessions is not based on a previous short story or novel. From this aspect, Bathseba is also an exception in Kallas' drama works, because it is not directly based on any of her previous works.

When writing Bathseba, Kallas became acquainted with The Bible. In her journals, she describes the writing process of the play as follows:

I started to read the Old Testament. It felt like I had slightly opened the door of a new temple of beauty (Aino Kallas' journal 5.5.1909, FLS LitA.)

I have intentionally taken many quotations from The Bible - linguistic, in particular - to have an appropriate accent. Don't I have a freedom to use biblical proverbs and, for example, Finnish sayings? (Aino Kallas' journal 26.11.1909, FLS LitA.) ${ }^{12}$

In Kallas' following works, then, pastiches in the Biblical style become significant. In one of her most famous short stories, "Lasnamäen valkea laiva" [The White Ship] (1913), Kallas uses both the styles and themes of The Bible, especially referring to the Exodus story and to the Gospels. Traditionally, the Biblical quotes have also been seen as an important part of the so-called archaistic style of Aino Kallas, particularly in her historical novels of the 1920s (Laitinen 1995, 132-135). In her later recollection Kolmas saattue kanssavaeltajia ja ohikulkijoita [The Third Group of Fellow Travelers and Passers-by. Memories and Portraits] (1947), Kallas describes The Bible as a source of inspiration for her fiction - from Bathseba to the trilogy Surmaava Eros [Eros the Slayer], (1923-1928). According to these notes, Kallas read the whole Bible in 1908. Later, when writing the Eros the Slayer trilogy, she read daily some sections from the Old Testament in order to adapt its style to her own text.

Bathseba can, naturally, also be compared with Kallas' early short story "Bath-Sheba of Saarenmaa" (1905) and with its dramatic version of the same title (1932). All the three works are, thus, based on the same Biblical triangle story between Bathsheba, King David and Uriah. When the play Bathseba was still unknown, it had sometimes even been supposed as an early version of the play Bath-Sheba of Saarenmaa. ${ }^{13}$ When reading the two plays concurrently, this interpretation is, however, hardly acceptable. First and foremost, Bath-Sheba of Saarenmaa is situated in an Estonian milieu, in the 1850s. It is also written in prose, like all of the published plays of Aino Kallas. Moreover, 
the plot, the scenes, main figures and events of the two plays are significantly different. Bathseba (1909) and Bath-Sheba of Saarenmaa (1905 and 1932) are, thus, independent works, but there also are some intriguing similarities between them. Next, I will briefly investigate some of them.

The problematic relationship between a mother-in-law and a daughterin-law in Bathseba (1909) reoccurs in both versions of Bath-Sheba of Saarenmaa. The majority of the short story and the play Bath-Sheba of Saarenmaa consist of a quarrelsome dialogue between a mother-in-law Vana-Kai ("the Old Kai") and a daughter-in-law Viiu (Riina in the drama version). Like Ketura, Vana-Kai also doubts the fidelity of her daughter-in-law in both versions of Bath-Sheba of Saarenmaa. Nevertheless, neither Ketura nor VanaKai are only representations of an evil mother-in-law; they are also loving mothers of an only son. Indeed, Kallas herself considered the play version of Batshseba at Saarenmaa as a tragedy of maternal love. In 1932, she wrote to her long-time friend, a Finnish critic and dramaturge Anna-Maria Tallgren (1886-1949) as follows:

I am happy that you like Bathseba. [meaning Bath-Sheba of Saarenmaa (1932), SV]. I myself have not now compared it with the "dialogue", - I only know, that in the dialogue Vana-Kai was a mean and a bilious hag, in the play I tried to make her more humane. Using folksy idioms was new, as well as the murder at the end of the drama, and also a couple of other scenes. I have also corrected and deepened the plot and characters.

[ - - ]

Naturally, it is almost impossible to place Bathseba [meaning Bath-Sheba of Saarenmaa (1932), SV] in any theatrical production. Moreover, it is not nice to share the evening's show with any other. Once, I had also planned to dramatize "Imant and his mother", if it succeeded. If I also deepened the tragedy of VanaKai, I would get two mother tragedies. "Imant" would then become a 4 -scene play. These two plays would form a coherent program. (Vuorikuru 2008, 165.) ${ }^{14}$

Three years after Bath-Sheba at Saarenmaa (1932), Kallas published a play called Mare ja hänen poikansa [Mare and Her Son], (1935), which was later known as her most famous tragedy of maternal love. However, the motif of a passionate mother's love also appears, in Kallas' early fiction, as the short story "Bath-Sheba of Saarenmaa" (1905) and Bathseba (1909) indicate.

Another conjunctive motif between Bathseba and both versions of BathSheba of Saarenmaa is the motif of childlessness. Both Bathseba and Viiu/ Riina are childlessness women. ${ }^{15}$ Their mothers-in-laws, Ketura and VanaKai, accuse them of this. Childlessness defines Bathseba and Riina/Viiu more or less as failures in their roles as married wives.

[Ketura to Bathseba, SV] “- at your age / I had three shoots to shelter / Uria the first, Thonor the second / And the third beneath my bosom..." ${ }^{16}$ (Kallas 1909, 24, ELM LitA).

If only you too had a child, you would look after it. Then perhaps Siim would not have been taken as a soldier, so rarely does the emperor send for his own 
kin. But no, barely two years into manhood, and thin as a stalk of hops. (Kallas 1932, 19.)

What use is a childless wife - she is like the fallow field! (Kallas 1932, 20.) ${ }^{17}$

In Bathseba, the motif of childlessness is also more closely connected to the Biblical subtext of the play. In the Second Book of Samuel and in Bathseba, childlessness is a godly punishment for a womans sins. In both texts, Michal/Micha, one of King David's many wives, is chastised for barrenness because of her disrespectful attitude towards "the chosen one", that is to say, King David himself (2. Sam. 6, 16-23). In Bathseba, however, the misery of Micha is described in a detailed way. For instance, Micha complains of her destiny in the following words:

- o how it wilts

This bosom once so fulsome, o wither

These hips, childless, never will

I bear fruit...

(...)

$\mathrm{O}$, to be

As the lifeless earth!

(Kallas 1909, 7, ELM LitA.) ${ }^{18}$

What about, then, the title character of the play, Bathseba herself? What kind of figure is she? Is she comparable with Kallas' other, better-known female figures?

The female figures of Aino Kallas' oeuvre have been frequently analysed in previous research. They have been described as ambivalent figures, who balance themselves between the responsibilities of the social community and their independent desire (Laitinen 1973, 270-273; Melkas 2006, 232). In previous research, Maie Merits, the main character in a short story "The White Ship of Lasnamäe", is designated as the first ambivalent female figure in Aino Kallas' oeuvre (Rojola 1995a, 74-75, 83 and 1995b, xiii). The figure of Maie Merits, a housewife who leaves her home and becomes a prophet of a religious cult, has been compared with the better-known female figures of Kallas' later fiction. These are, first and foremost, the title character of Barbara von Tisenhusen, Catharina Wycken in Reigin pappi [The Rector of Reigi] and Aalo in Sudenmorsian [Wolf's Bride]. ${ }^{19}$

Nevertheless, the theme of a woman's ambivalence appears already in Bathseba. The title figure loves two men at the same time - her husband Uria and the unknown King David - feeling, simultaneously, guilt and desire. In the third scene of the play, Bathseba describes her contradictory feelings by speaking to King David the following words:

Oh, king, cleft in two

Is my life, two lives,

At once I live, one but a dream,

And the other true - but which,

I do not know... As you depart 
You dissolve, a fantasy, an illusion,

As a mirage rising in the eye

Of one wandering in the desert,

Far across the shimmering air - thus

you disappear

And fade in my eyes...

(Kallas 1909, 45,. ELM LitA.) ${ }^{20}$

Thus, the figure of Maie Merits is not the very first ambivalent female figure in Kallas' oeuvre. Kallas discusses the themes of ambivalence, contradictory feelings and a divided life and self already in the early Bathseba. Thus, the main figure of the play can also be compared with the later famous female figures of Aino Kallas. Moreover, Bathseba also dies in a violent way. A violent death is a consequence of her more or less independent life choices, which also connect her figure to the main female characters of the trilogy Eros the Slayer.

\section{Bathseba and the later lyrics of Aino Kallas}

As an author, Aino Kallas is best known as a prosaist. In her lifetime, she published only five anthologies of poetry. Kallas' poems have received less attention and more negative criticism than her works in prose. However, it is justifiable to compare Kallas' unpublished poetic play Bathseba with her (mostly poorly known) lyrics, as I will indicate next.

In the third scene of Bathseba, the main figure represents a poem, which is called Bathseban laulu [The Song of Bathseba]. The poem reflects the experience of the divided life and self of the title character.

The song of Bathseba

$\mathrm{O}$, if I could forget

That once I had lived,

O, if I could be born

Upon this very moment!

$\mathrm{O}$, if eyes could forget

That which they have seen,

And ears could forget

That which they have heard!

$\mathrm{O}$, if I could drown in him,

As the banks into floodwater,

$O$, if I could forget

That once I had lived...

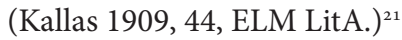

In Kallas' later anthology of poetry, Kuoleman joutsen [The Swan of Death], (1942), there is a poem called "Unhoitus"[Oblivion]. One can easily notice, how closely it resembles the unpublished "The Song of Batshseba". 


\section{Oblivion}

$\mathrm{O}$, if only my eyes could forget

that which they have seen!

And my ears would forget

That which they have heard!

$\mathrm{O}$, if only I could drown,

as the banks into floodwaters!

$\mathrm{O}$, if only I could sink

like a wave into the sky!

$\mathrm{O}$, if only I could forget

that I lived long ago!

$\left(\right.$ Kallas 1942, 136) ${ }^{22}$

Kai Laitinen asserts, that the only saved poems of a "disappeared" Bathseba were "Oblivion" and a poem called "Seitsemän hunnun tanssi" [The Dance of Seven Veils], which is also included in The Swan of Death (Laitinen 1973, 163). As one can easily notice, "Oblivion" is obviously based on "The Song of Batshseba". Instead, "The Dance of Seven Veils" does not clearly resemble any single poem of Bathseba.

\section{The Dance of Seven Veils}

The seven veils dispersed like seven wisps, how wonderful you are among the maidens!

When you cast your veil, the old land is dyed, dance, dance, spin round, spin round!

Bliss, give me bliss, o purple mouth, a man shall lose his mind, and blight is silenced, dance, dance, spin round, spin round! Death, give me death, o poisoned lips. How wonderful you are among the maidens! (Kallas 1942, 55-56. $)^{23}$

Why did Kai Laitinen suppose, that "The Dance of Seven Veils" is based on the poems of Bathseba? Possibly, an early version of "The Dance of Seven Veils" was included in some earlier version of the play, but not in the finished version. As Aino Kallas' journals suggest, the author wrote several drafts of the play.

The speaker of "The Dance of Seven Veils" is most likely a male character, speaking to an adorable, mysterious and, also, more or less, dangerous woman. The woman is like the Biblical Salome, who can slay a man by her beauty and marvellous dancing. Thus, this figure of a dangerous woman also resembles the character of Bathseba, whose beauty indirectly causes Uria's death. Moreover, the motif of "seven veils" also appears in Bathseba, in two David's songs. 
David's first song to his unknown beloved

My beloved has shut her wonder behind lock and key

And hidden her sweetness in

a sevenfold veil

the more my yearning to

swell

and make my love torrid as

the flood.

Sela!

(Kallas 1909, 14, ELM LitA.) ${ }^{24}$

David's second song to his unknown beloved

Behold, the sevenfold veil fades like dawn's mist

And flees like seven clouds,

My eyes are blinded by a great

brightness,

Will this sacred source cure their

darkness?

Sela!

(Kallas 1909, 15, ELM LitA.) $^{25}$

The poems of the early, unpublished Bathseba closely resemble the poetry of the Old Testament, in particular the Psalms. In places, the poems of Bathseba can even be described as pastiches of Biblical poetry. Both the diction and the verse of the poems of Bathseba imitate the style of the Biblical poetry.

In Kallas' published oeuvre, however, pastiches of the Biblical poetry did not appear until the 1940s. In the early 1940s, Kallas published three anthologies of poetry: The Swan of Death (1942), Kuun silta [Bridge of the Moon] (1943) and Polttoroviolla [On the Funeral Pyre] (1945). The numerous poems of this era imitate the style of Biblical poetry as much as Bathseba. Take a poem of On the Funeral Pyre called "Viimeinen virsi" [The Final Hymn] for example:

Ring, harp, for on the morrow you shall

fall silent,

your silver strings will snap with deepest sighs,

and your golden tongue will weep with pain,

for you shall be silent, tongueless, like the soil

and the earth,

but Lord, more wondrous than wonder to ring and sound

and sing high the wonderment of Love and Death,

Sela!

$(\text { Kallas 1945, 134. })^{26}$ 
Imitating the biblical style is characteristic not only of Kallas' later poetry, but also of her works of prose also. In her published oeuvre, Kallas also widely refers to the Biblical myths, themes and figures, although none of her published works is situated in a Biblical milieu and time. In Bathseba, therefore, Kallas operates with the similar stylistic and thematic features, which appear in her published oeuvre even decades later.

As mentioned before, Kallas wrote three versions of the Biblical story of Batshseba. One can wonder, why this story fascinated Aino Kallas so much. One explanation would focus on the dramatic and tragic themes in the original story. The main themes of the Biblical story of Batshseba - like the triangle love story, adultery, conjoined themes of forbidden love and death - are also characteristic to Kallas' later oeuvre.

\section{The "Disappearance" of Bathseba}

In her old age, Aino Kallas noted, that the manuscript of Bathseba had been lost. A contemporary scholar can only guess, why the author so claimed. As said before, she probably meant some other version of the manuscript in her letter to Kai Laitinen. Or, probably she did not remember the whole issue very well any more. It is also possible, that, decades later, she just did not want to recall this early, a so-called failed work. It is unclear, when the manuscript of Bathseba was brought to the Estonian Literary Museum. Oskar Kallas, the founder of the museum, brought some archive materials of his family there already in 1934. However, the majority of Kallas' archive materials have arrived to the museum between 1946 and 1949. ${ }^{27}$ In any case, the manuscript of Bathseba has been included in the archive collections of the museum for decades. Why did no one find the manuscript earlier? One obvious explanation can be found in Estonian history. During the Soviet era, it was difficult to gain access to the archive collections of the Estonian Literary Museum. In fact, outsiders were not even allowed to visit Tartu for a long time. Moreover, in Kallas' oeuvre, there are several manuscripts titled as "Bathseba". That is to say, there are different versions and translations of Bath-Sheba of Saarenmaa. The manuscript of Bathseba has probably been interpreted as one of these different versions of Bath-Sheba of Saarenmaa, which is, as said before, a totally different work.

Bathseba was also lost in Finland. On March 2008, I came back to Helsinki, and visited the Literary Archive of the Finnish Literary Society. I learned, that the copy of the original manuscript of Bathseba was included in the collections of Finnish Literary Society, too. When I wanted to examine the copy of the manuscript more closely, it became clear, that I was its first reader. The copy had been received in Finland in 1984, but in Spring 2008, it still was unopened. Hannu-Pekka Lappalainen, who worked as a secretary in the Friedebert Tuglas Society on 1984, had delivered the copy to Finland. According to Lappalainen, the selection and copying of the archive materials was done in Tartu, strictly controlled by the national security agency of the Soviet Union, the KGB, but Lappalainen himself did not participate in the selection and copying process of the materials ${ }^{28}$. 


\section{Bathseba - an unsuccessful work?}

In 1910, Jalmari Hahl released his crushing critique of Aino Kallas' Bathseba. Because of this, the play remained unpublished. Now in 2009, it is possible to re-evaluate the play. How does a contemporary reader and a literary researcher value Bathseba? Is it unsuccessful, as previous research has claimed - without even knowing the whole work (e.g., Laitinen 1973, 267)?

It is easy to accept some parts of Hahl's negative critique. As an extension of a famous Biblical story, Bathseba can be described as more or less outof-date already in its own time. In places, the verse of the play is, without doubt, awkward, as Hahl suggests. As a contemporary researcher of Aino Kallas' fiction, I would not place Bathseba among the best works of Kallas' oeuvre. Nevertheless, from a contemporary point-of-view, Bathseba can also be described as an intriguing work. At least, it is a fascinating middle work between earlier and later, better-known parts of Kallas' oeuvre.

One fascinating detail of Bathseba is the way the play refers to Biblical style. According to her journals, Kallas became acquainted with the style and thematics of The Bible while writing Bathseba. In the play, indeed, include numerous archaic words, which are based on the old versions of the Finnish Bible. These archaic words are, for instance, priiskoo [sprinkleth], epha-mitta [ephah], templi [an archaic form of the word "temple"]. According to Hahl's notes in the manuscript, he did not totally understand this poetic manner. For instance, Hahl has marked a word lipilaari with a question mark. However, this word (meaning "blabber") is included in the Finnish Bible of 1776 (e.g., The Acts 17, 18). The later translations of The Bible use the synonymous expression lavertelija. (Ikola 1992, 55.) Consequently, Bathseba indicates, that Aino Kallas uses the Biblical and archaic language already in 1909. In Bathseba, therefore, a contemporary reader can see the first traces of the so-called archaic style of Aino Kallas, which usually is connected to her prose ballads from the 1920s and 1930s.

The themes and milieu of Bathseba are also closely connected to the Biblical world. For instance, there are mentions of maids of Israel singing victory songs to the Israeli King in the play. Moreover, the play refers to other events in the Old Testament. Kallas has also modified some of the biblical characters in her play. For example, in Bathseba, Mephi-Boseth, who in The Bible is a humble servant of King David, actively hates his ruler. Therefore, Kallas refers to the Biblical themes and comments on them already in her early fiction. In his response to Kallas, Jalmari Hahl particularly mentions the figure of Mephi-Boseth. Hahl relates to this figure in an ambivalent way. On the other hand, he considers Mephi-Boseth as the most intriguing figure of the play, yet perceives the figure as too modern for the milieu of Old Testament. One could remind, however, that the main figure David in Volter Kilpi's Bathseba is also a modern figure in a Biblical world. As Kallas' journal notes indicate, after Hahl's critique, when planning to write Bathseba once again, she intended Mephi-Boseth to be the new main figure of the play.

Bathseba is an intriguing work also as a part of Kallas' oeuvre. Frequently, Kallas has been evaluated as an atypical Finnish author, whose works are not closely connected to other contemporary Finnish literature. Bathseba indi- 
cates, however, that Kallas also utilises popular themes of literature of her own time and culture. For instance, Bathseba refers to famous themes of Finnish symbolism of the turn of the $20^{\text {th }}$ century, as mentioned earlier.

Although a contemporary reader hardly places Bathseba among the best works of Aino Kallas, the play and the writing process of it certainly reflect interesting features of Kallas' literary career in the first two decades of the $20^{\text {th }}$ century. The Biblical milieu of the play differs from the historical, mainly Estonian contexts of Kallas' better known works, but the relationship with Biblical mythology and Biblical style of the play are familiar to Kallas' published works, too. As a writer of Bathseba, Kallas is strongly related to the context of Finnish literature at the turn of the $20^{\text {th }}$ century. However, through the main themes and characters of Bathseba, a contemporary reader is introduced to the complex literary character of Aino Kallas.

(Translations of Kallas' Bathseba, Bath-Sheba of Saarenmaa, Kuoleman joutsen and Polttoroviolla by David Hackston. Other translations by Silja Vuorikuru.)

\section{Notes}

1. This play was also translated to English by Alex Matson in 1934. "Bath-Sheba of Saarenmaa" was included in a short story collection Eight New One-Act Plays.

2. [Joskus näytelmässänne pistää esiin modernisuutta. (...) 'Suihkulähteet', 'ruokalistat' y.m. eivät tunnu muinais-hebrealaisilta.] (Jalmari Hahl's letter to Aino Kallas 19.11.1910, FLS LitA.)

3. [Modernia!] and [Tuntuu hieman modernilta: ruokalista]. (Jalmari Hahl's letter to Aino Kallas 19.11.1910, FLS LitA.)

4. [Kuljin vuorilla, ajattelin Bathsebaa. Tämäkö on se väylä, johon luomisvoimani lopulta purkautuu?] (1.5.1909, ELM LitA.) [Ajattelen alati Bathsebaa.] (11.5.1909, ELM LitA.)[Bathseba on vielä kuin tyhjä malja. Mutta kuitenkin luulen siihen mahtuvan koko sisältöni.] (ELM LitA, 17.5.1909.)

5. [Vielä pari päivää, ja Bathseba on valmis - tietysti vain luonnoksena, mutta täydellisenä luonnoksena. Uskon ja epäilen vuorotellen - Bathsebaan nimittäin.] (ELM LitA, 12.11.1909.) [Kuka on kirjoittanut Bathseban - minäkö vai joku muu! Ja minkä arvoinen on Bathseba?] (4.12.1909, ELM LitA.)

6. Biblical person names are written in different ways in Finnish and in English translations of The Bible. Some variation also exists between different editions of the Finnish Bible. When I speak of Kallas' works, I use the names included in these works (for instance, Bathseba, Uria, Mephi-Boseth, Jonatan). When speaking of the Biblical narrative in general, I use the names from the King James Bible (for instance, Bathsheba, Uriah, Mephibosheth, Jonathan).

7. Tämä teidän aiheenne on sitäkin vaativampi, kun Teitä ennen, eikä niin kovin kauan sitten, suomalainen kirjailija on sitä käsitellyt, nimittäin Volter Kilpi, tosin romaanin muodossa, mutta melkoista huomiota herättäen.] (. (Jalmari Hahl's letter to Aino Kallas 19.11.1910, FLS LitA.)

8. [Tahtoisin lukea Volter Kilven Bathseban. Olen siitä aikoinani lukenut vain alun. Tulleeko se häiritsemään työtäni - en tiedä.] (Aino Kallas' journal 27.11.1909, FLS LitA.)

9. [Puhkeeko nyt siis kukka myrkkyinen? / Sen siemen sielussani kauan iti / Visusti 
verhottuna, etten aina / Itsekään siitä tiennyt...]

10. [Mitä kirjoitinkaan/ - Voin pyyhkiä sen pois ja kuitenkin/ Se jossain kirjoitettu on.../ ma vain/ Sen jäljensin ja toinen/ kaiken/ aikaa/ Piirrintä kuljetti...Oi, kuolemaa/ On lehto täynnä, lehdet lakastuu/En katumusta tunne, suloista/ On olla julma, murhan tehdessäni/ Itseni löysinkö, sinetti viimeinen/ Kun murtui, - tuhota, hävittää Sisintä itseäni on, - kumpusiko/Tää teko kuten suihku suonen/ Salaisen, maassa kauan piilleen.]

11.[Oi suuri David/ On kaksoisia yhteenkasvaneita/ Onneton luonnonoikku toinen/Hirveä leikki, julma hairahdus, Ja toinen täydellisyys itse, taivaasta/ Astunut alas mailman auringoksi./Vaan sydänveret yhteen virtaavat/Ja lämmönlähde molemmil'on sama,/ Ravinto yksi kumpaistakin ruokkii,/Jokaisen liikkeen tuntee kumpikin Jokaisen kosketuksen, irti koskaan/ Ei toisistansa pääse.../(...)Yhtaikaa syntyi David, sielussasi Rakkaus, murhanhimo...]

12. [Rupesin lukemaan Vanhaa Testamenttia, on kuin olisin raottanut uuden kauneudentemppelin ovea.] [Olen tahallani tehnyt paljon lainoja - varsinkin kielellisiä - Raamatusta saadakseni paikallisväritystä. Ja enkö ole yhtä oikeutettu käyttämään Raamatun sananlaskuja kuin esimerkiksi suomalaisia sananlaskuja?]

13. For instance, this is Riitta Kallas' interpretation of the unpublished and unknown Bathseba (Kallas 1988, 402). Riitta Kallas, the first spouse of Aino Kallas' son Hillar Kallas, has published the letters of Aino Kallas, Helmi Krohn and Ilona Jalava. Some information on the writing process of Bathseba is also included in these works (Kallas 1988).

14. [Olen onnellinen, että pidät Bathsebasta. En ole itse nyt verrannut sitä "dialogiin", - tiedän vain, että Vana-Kai oli siinä häijy, kiukkuinen akka, koetin tehdä hänet inhimillisemmäksi. Kansanomaisten lauseparsien käyttö on uutta, samoin murha draaman lopussa ja pari muutakin kohtausta; muutenkin olen juonta hieman oikonut ja syventänyt. Henkilöitä samoin.][ - - ][Bathsebaa yksinään tietysti lienee miltei mahdotonta sijoittaa mihinkään ohjaukseen, paitsi sitä, ei ole hauskaa jakaa iltaa toisen kanssa. Olin kerran ajatellut sitäkin, että dramatisoisin "Imantin ja hänen äitinsä", jos se onnistuisi, ja jos samalla vielä hiukan syventäisin Vana-Kain tragiikkaa, niin saisin kaksi äiti-tragediaa. "Imantista" tulisi tietysti 4-näytöksinen, jotka muodostaisivat yhtenäisen ohjelman.]

15. On 1909, Kallas also commented on J.Randvere's (Johannes Aavik's) Ruth (1908), which had been an occasion in the contemporary field of Estonian literature. Kallas, for example, described Ruth as a "woman without maternal instincts". (See also Hinrikus 2006 and especially Kurvet-Käosaar's article in the same anthology.)

16. [Ketura Bathseballe, SV] [- sun ijässäsi / Mull' oli kaksi vesaa vaalia / Uria esikoinen, Thonor toinen / Ja kolmas alla rinnan...]

17. [Olisi sinullakin edes lapsi, niin hoitelisit sitä. Ei olisi silloin Siimua ehkä sotamieheksi tahdottukaan, harvoin keisari perheellisiä kysyy. Vaan ei, toista vuotta jo miehellä ja hoikka kuin humalanseiväs.] (Kallas 1932: 19.) [Mihinkä lapseton vaimo kelpaa, on kuin kesantopelto!]

18. [- oi kuihtuu/Tää kerran täysi povi, lakastuu/Nää lanteet lapsetonna enkä koskaan/Ma hedelmätä kanna.../Oi, olla Kuin marras maa!]

19. Aino Kallas' ambivalent female figures have also been interpreted biographically. Living too lives simultaneously is a theme which has been connected to Kallas' life history. According to this interpretation, Kallas, in her oeuvre, describes the ambivalent role of a female artist in her own time (for instance, Rojola 1995a: 7576). In her journals, too, Kallas writes about the problematics of being a woman, a mother and an artist.

20. [Ah, kuningas, katkaistu kahtia/On elämäni, kahta elämää,/Yhtaikaa elän, unta toinen lie,/Ja toinen totta, - mutta kumpiko,/En tiedä...Luotani kun loittonet/Vain harhaks haihdut, unikuvaks vain,/Kuin aavikolla vaeltajan silmään Hehkuva helleilman kaukaisen/Kohottaa kangastukset, - niin/myös häivyt/Hämärryt multa...] 
21. [Bathseban laulu] [Ah, jos unohtaa voisin/Että ennen elin,/Ah, jos syntyä saisin/ Helmasta hetken tämän!/Ah, jos unohtaisivat silmät,/Minkä he nähneet ovat,/Ja unohtaisivat korvat,/Minkä he kuulleet ovat!/Ah, jos hukkuisin häneen/Niinkuin tulvaan äyräs,/Ah, jos unohtaa voisin,/Että ennen elin...]

22. [Unhoitus] /[Ah, jos unhoittaa voisivat silmät,/minkä he nähneet ovat!/Ja unhoittaisivat korvat,/minkä he kuulleet ovat!/Ah, jos hukkua saisin,/niinkuin tulvaan äyräs!/Ah, jos vaipua voisin/niinkuin aaltoon taivas!/Ah, jos unhoittaa voisin/että ammoin elin!]

23. [Seitsemän hunnun tanssi]/[Seitsemän huntua haihtuvi kuin seitsemän hattaraa,/ ihana olet sinä impien seassa!

Kun sa hunnun heität, niin värjyy vanha maa,/tanssi, tanssi, kierrä, kierrä!/Autuuden, ah, autuuden suo purppurainen suu,/menee miehen mieli, ja vaiva vaimentuu,/tanssi, tanssi, kierrä, kierrä!/Kuoleman, ah, kuoleman suo myrkkyhuuli suu./Ihana olet sinä impien seassa!]

24. [Daavidin ensimmäinen laulu tuntemattomalle rakkaalleen]/[Minun armaani on lukinnut ihanuutensa lukkojen taakse/Ja peittänyt sulonsa seitsenkertaisella/hunnulla/että minun ikäväni ylenpalttiseksi/paisuisi

Ja minun rakkauteni rajuksi kuin/tulva./Sela!]

25. [Daavidin toinen laulu tuntemattomalle rakkaalleen]/[Katso, seitsenkertainen huntu haihtuu/kuin huomensumu

Ja pakenee kuin seitsemän pilveä,/Silmäni ovat sokaistut ylen suuresta/valkeudesta,/Taitaako pyhä lähde niitten pimeyttä/parantaa?/Sela!]

26. [Helise, harppu, sillä koska huomen koittaa, pitää/Sinun vaikeneman,/sinun hopeakielesi katkeavat syvästi huokaisten,/ja sinun kultakielesi itkee säryissänsä,/ kohta olet sinä mykkä ja kieletön, niinkuin multa ja/ maa,/mutta Herra, ihanaakin ihanampaa oli helistä ja soida/ja laulaa julki Rakkauden ja Kuoleman ihanuus,/ Sela!]

27. Oskar Kallas died in 1946.

28. Emails from Hannu-Pekka Lappalainen 5.3.2008, 14.4.2008 and 15.4.2008.

\section{References}

\section{Research objects}

Kallas, Aino 1995: Lähtevien laivojen kaupunki. [The City of Departing Ships.] Helsinki: Suomalaisen Kirjallisuuden Seura.

Kallas, Aino 1932: Bathseba Saarenmaalla. Yksinäytöksinen näytelmä. [Bath-Sheba of Saaremaa. A drama in one scene.] Helsinki: Otava.

Kallas, Aino 1945: Polttoroviolla. [On the Funeral Pyre.] Helsinki: Otava.

Kallas, Aino 1947: Kolmas saattue kanssavaeltajia ja ohikulkijoita. Muistoja ja muotokuvia. [The Third Group of Fellow Travellers and Passers-by. Memories and Portraits.] Helsinki: Otava.

Kallas, Riitta 1988: Kolme naista, kolme kohtaloa. Aino Kallaksen kirjeenvaihtoa Ilona Jalavan ja Helmi Krohnin kanssa vuosina 1884-1913. [Three Women, Three Destinies. Aino Kallas' Correspondence Between Ilona Jalava and Helmi Krohn from the years 1884-1913.] Helsinki: Suomalaisen Kirjallisuuden Seura.

Kilpi, Volter 1995: Bathseba. Davidin puheluja itsensä kanssa. [Batshseba. David's Monologues.] Helsinki: Suomalaisen Kirjallisuuden Seura. 
Vuorikuru, Silja (ed.) 2008: Elämisen taiteesta. Aino Kallaksen ja Anna-Maria Tallgrenin kirjeenvaihtoa. [Art of Living. Correspondence Between Aino Kallas and Anna-Maria Tallgren.] Helsinki: Otava.

\section{Unpublished sources}

Estonian Literary Museum, Literary Archives (ELM LitA)

Kallas, Aino 1909: Bathseba. Runonäytelmä 5-ssä näytöksessä. [Bathseba. A poetic drama in five scenes.] Tartto - Elva. KM EKLA F. 18620 / 3.

Finnish Literary Society, Literary Archives (FLS LitA)

Aino Kallas' journals (1909 and 1910).

\section{Research Literature}

Blomstedt, Jan. \& Lõhmus, M. \& Tarasti, Eero (ed.) 1995: Ajan arvot \& sankarit. [The Values and the Heroes of Our Time.] Helsinki - Tartto: Kullervo-Synteesi.

Ikola, Osmo 1992: Raamatun vaikutus kirjasuomeen. [The Influence of the Bible in Written Finnish] In: Jussi Nuortena (ed.), Biblia 350. Suomalainen Raamattu ja Suomen kulttuuri. [Biblia 350. The Finnish Bible and the Finnish Culture.] Helsinki: Suomalaisen Kirjallisuuden Seura.

Kurvet-Käosaar, Leena 2006: Aino Kallase haakumisi J. Randvere "Ruthiga" moodsa naise kuju pinnalt." [The Notion of the Modern Woman in the Work of Aino Kallas and J. Randvere's "Ruth".] In: Mirjam Hinrikus (ed.), J. Randvere "Ruth" 19. - 20. sajandi vahetuse kultuuris. Tallinn: Underi ja Tuglase Kirjanduskeskus.

Laitinen, Kai 1973: Aino Kallas 1897-1921. Tutkimus hänen tuotantonsa pä̈linjoista ja taustasta. [Aino Kallas 1897-1921. Research on the Main Topics and Background of her Work.] Helsinki: Otava.

Laitinen, Kai 1995: Aino Kallaksen mestarivuodet. Tutkimus hänen tuotantonsa päälinjoista ja taustasta 1922-1956. [The Master Years of Aino Kallas. Research on the Main Topics and Background of her Work 1922 -1956.] Helsinki: Otava.

Lyytikäinen, Pirjo 1995: Bathseba ja Volter Kilpi. [Batshseba and Volter Kilpi.] In: Volter Kilpi, Bathseba. Daavidin puheluja itsensä kanssa. [Batshseba. David's Monologues.]. Helsinki: Suomalaisen Kirjallisuuden Seura.

Lyytikäinen, Pirjo 1997: Narkissos ja sfinksi. Minä ja Toinen vuosisadanvaihteen kirjallisuudessa. [Narcissus and the Sphinx. I and the Other in the Literature of the Turn of the Century.] Helsinki: Suomalaisen Kirjallisuuden Seura.

Melkas, Kukku 2006: Historia, halu ja tiedon käärme Aino Kallaksen tuotannossa. [History, Desire, and the Serpent of Knowledge in the Works of Aino Kallas.] Helsinki: Suomalaisen Kirjallisuuden Seura.

Riikonen, Hannu, K. 2003: Raamattu ja kirjallisuus: lähtökohtia ja esimerkkejä. [The Bible and Literature: Starting Points and Examples.] In: Larjo Lassi (ed.), Raamattu ja länsimainen kulttuuri. STKS:n symposiumissa marraskuussa 2002 pidetyt esitelmät. [The Bible and Western Culture. Presentations of the STKS symposium in November 2002.] Helsinki: Suomen Teologinen Kirjallisuusseura.

Rojola, Lea 1995: Naisen kieli ja hysteria: Maie Meritsin henkilökuva Aino Kallaksen novellissa 'Lasnamäen valkea laiva'. [Woman's Language and Hysteria: The Portrait of Maie Merits in Aino Kallas' Short Story "The White Ship".] In: Jan Blomstedt, Maarja Lõhmus, Eero Tarasti (eds.), Ajan arvot \& sankarit. [The Values and the Heroes of the Time.] Helsinki - Tartto: Kullervo-Synteesi. (1995a)

Rojola, Lea 1995: Omaa ääntä etsimässä. [In Search of a Voice of One’s Own.] In: Aino Kallas, Lähtevien laivojen kaupunki. [The City of Leaving Ships.] Helsinki: Suomalaisen Kirjallisuuden Seura. (1995b) 


\title{
Goethe, Master!
}

\author{
Reading Goethe with Aino Kallas \\ and her Contemporaries
}

As a flying shingle is part of a dense pine tree, so I have had the deep feeling that I am of the same substance as Goethe. I would never have been able to take him into my very being so organically, had I not been put together of the same elements. This is the only way I can explain the power of rebirthing that he has over me. My life has gained in joy and clarity from the time I discerned that living boundary stone. (Kallas 1953, 141-142.) ${ }^{1}$

What did Goethe mean for Aino Kallas? There are not many direct references to Goethe or Goetheian motifs in the literary works of Aino Kallas. But in her diaries, Kallas makes more frequent mention of Goethe than any other writer, living or dead. I would like therefore to use the diaries and the reception of Goethe in Estonia, Finland, and Germany at the time of the writing of the diaries in order to discern Goethe's role in Aino Kallas' pursuit of aesthetic self-understanding.

In her diaries, Kallas often used quotations from Goethe (see, e.g., Kallas $1953,136,158,171,238 ; 1956,202)$ that point to a thorough knowledge of Goethe's literary works, and possibly the quiet hope that her readers will recognize the quotations. Kallas' reading of Goethe was particularly intense and systematic in 1908-1909, when she obtained an 18-volume edition of Goethe $^{2}$, devouring it volume by volume. The order in which she read was also documented in the diary: Werther, Wahlverwandschaften, Dichtung und Wahrheit, Wilhelm Meisters Lehrjahre, Hermann und Dorothea, and Italienische Reise. Only after reading all of these works did she undertake reading Faust, and there is a short entry in the diary to that effect: "Because of Faust I dreamed the whole day and was awake all night"3 $(1953,138)$. The plays came next: Iphigenia in Tauris awakened only a feeling of a cold admiration in her, while Torquato Tasso seemed more human and gave her the courage to tackle Natürliche Tochter, Wilhelm Meister's Wanderjahre, and Part II of Faust, which she had stopped reading earlier, since she "could not bear crossing over into that deathly clarity" 4 (Kallas 1953, 205). For Kallas, Goethe is "more and more the great origin", even with respect to reading of the Greek dramatists and Shakespeare. 
The experience of reading Goethe is powerful and all-encompassing: "With Goethe I have a 'mystical union"” she wrote. "I have no need to open his books in order to find him in them. I live in his atmosphere like a disciple in the ambience of the Master"s (Kallas 1953, 167). Kallas compared her experience of Goethe with a religious awakening: "Through Goethe it is as if I were born anew. He draws my whole being like a magnet draws iron, and I can have no peace before I have merged with him completely. This is what a religious awakening must feel like" ${ }^{6}$ (Kallas, 1953, 160). It is curious, however, that one can find no trace of such reading in Kallas' own works from this time. The verse play Batseba, based on a Biblical theme, created during the time of Kallas' most intense engagement with Goethe, was a disappointment and was never published. ${ }^{7}$

From about 1910, Kallas' enthusiasm for Goethe begins to fade, and diary notations about Goethe's works become more infrequent. More and more, contemporary authors are found on her desk: Schnitzler, Hoffmansthal, Keyserling, Wedekind, Maeterlinck, etc.; and she admits that "The spirit of modernism penetrates me more and more. My brain thinks in the key of modern times, while my feelings are still a legacy from the past. It is as if I want to make a leap into the new, while taking too much of the old along"8 (Kallas 1953, 185). As a writer, Kallas reached a watershed in her aesthetic persuasions, and it seems that from then on, she would no longer need Goethe. In what follows we only find a very few concret references to Goethe in the diary: as she reads Goethe to her children, Kallas still feels "quiet joy" (Kallas 1953, 320).

In the next diary volume where Kallas confesses to her great passion for Eino Leino, Goethe's intertextual presence can be felt not merely in the format of multiple quotes in the letters of Eino Leino who held Goethe in very high esteem (Kallas 1954, 114, 129, 179), but Goethe can also be viewed as a secret code of the love story of Kallas and Eino Leino. Aino Kallas compared herself to Mrs. von Stein (Kallas 1954, 214) whose "most powerful dream has always to be in the presence of grand creative genius"9 (Kallas 1954, 66). Kallas and Leino dedicated themselves to their relatioship with true Goethean explanation and justfication: "Alles geben Götter, die unendlichen, / ihren Lieblingen ganz"10 (1954, 114, 129), hoping to achieve in it the culmination of their life, the fulfillment of their destiny.

Later, as the wife of the British ambassador to London, Kallas explored English literature and relates to "Yeats, Synge and the Celtic spirit"11 (Kallas 1956, 159) but returned to Goethe in the end. She writes in 1930: "22 years ago I lay on the downstairs hall in Nummela and read Goethe. Now I am sitting on the balcony of the Estonian Embassy in London, twenty years older and reading Goethe again" ${ }^{12}$ (Kallas 1956, 273). She continues: "twenty years ago he helped me to find myself and afterwards my life has been one continious process of development ... why does he still make me shiver? He is still more alive for me than thousands and thousands of living souls...Why is he approaching again, why is his shadow crossing my path again? Am I approaching crossroads in my life again?" ${ }^{13}$ (Kallas 1956, 184). Goethe had indeed woken Kallas as a writer from "hibernation," she 
is suddenly full of initiatives and creative desire, working fevereshly on her novel on Hiiu Ungur.

Thus, preoccupation with Goethe coincides with Kallas' period of personal breakthrough, a time of aesthetic quest. Goethe had a role to play in these searchings, which in turn is most likely bound up with her educational background.

\section{Goethe in Estonia}

Biographers have emphasized that Aino Kallas blossomed into a creative writer in Estonia, under the influence of Estonian surroundings and Estonian literature. However, contemporary Estonian literaturary culture in Aino Kallas' time cannot be considered friendly to Goethe. In his lifetime Goethe was met with an enthusiastic welcome in the Baltic lands, but this enthusiasm waned after the master's death. The idol of Estonian national romanticism was Friedrich Schiller, in part due to Baltic German enthusiasm for him, and Estonia had the honour of being the first to commemorate Schiller (the first monuments to Schiller in the world were erected in the year of his death, 1805, in the Helme manor park, followed by Puhtulaiu in 1813). The middle of the 19th century, spanning the reign of Alexander I and Alexander II - both of whom named Schiller as their favourite poet - was the age of Schiller in Finland and the Baltic lands. Goethe was relegated to the background.

Goethe's generative influence on Baltic-German literature was rather small, and he had little to offer the growing literature of popular enlightenment besides Reineke Fuchs, the first Goethe text to find its way into the Estonian language. The somewhat epigonic Baltic-German and Estonian literatures chose less demanding authors as models. Fr. R. Kreutzwald, the father of Estonian literature, knew Goethe's works rather well and made frequent reference to him, yet he was forced to admit that translating Goethe's poetry was beyond his ability. In the work of Lydia Koidula, Estonia's "poet of the dawn", translations and borrowings from the German have an important place, but translations of Goethe's poetry are missing altogether, though she does mention him in her correspondence. ${ }^{14}$ Even though translations of Goethe's poetry were being published beginning in the 1860s, and the quality of the translations had improved by the turn of the century (in the ballad translations of Anna Haava, Jaan Bergmann, Jakob Tamm, and Juhan Liiv), by the time Aino Kallas engaged in her intensive reading of Goethe (1908-1909), the Estonian language was by no means goethereif. Janis Rainis' exemplary translation of Faust into Latvian had already been published in 1898, but for Estonian, this touchstone of Goethe-ripeness was as yet far beyond the horizon. ${ }^{15}$ Allusions to Goethe can be found in the works of the "Young Estonia" poets, with whom Aino Kallas interacted intensely (Gustav Suits, Friedebert Tuglas, A. H. Tammsaare, and especially Marie Under). However, it is not possible to speak of Goethe as a major influence on the Estonian writers of the beginning of the century. Likewise, the source of Aino Kallas' admiration for Goethe must be found elsewhere, 
in the Finland of her childhood, where Kallas gleaned a great deal for her future as a writer - and especially in her father, whom she held in very high esteem, and with whom she shared a strong spiritual bond. Along with the legacy of her father's intellectual influences, he may have bequeathed his own love for Goethe.

\section{Goethe in Finland}

The first Finnish translation of Goethe was published much earlier than the Estonian, indeed in the very year of Goethe's death, though the interest in Goethe in Finland is of much earlier origin, extending back into Goethe's lifetime. ${ }^{16}$ The founders of Finnish literature - Henrik Gabriel Porthan, Axel Gabriel Sjöström, and Immanuel Ilmoni - were all true admirers and translators of Goethe, albeit into Swedish at first. For the Helsinki romantics, led by Elias Lönnrot, Johan Vilhelm Snellman, and Johan Ludvig Runeberg, Goethe's declarations of cultural autonomy remained as foreign as the German Goethe-cult, although in the (Swedish-language) poetry of Johan Jakob Nervander and the (Finnish-language) poetry of Kyösti Kallio, traces of Goethe are amply evident; Runeberg's Hanna-epic has been compared with Goethe's Hermann and Dorothea (Grellmann 1948, 62). Just as in the Baltic lands, Finland in the 19th century was Schiller's era, ruled by those Russian emperors with a special fondness for Schiller. In 1851 Goethe is even spoken of in Finland as a forgotten writer (Grellmann 1948, 96). Goethe's 100th birthday passed practically unnoticed, while Schiller was celebrated in 1859 in Helsinki and Riga.

From the 1860 s on Goethe began to attract interest again, first in university lecture halls and shortly thereafter on stages: in his doctoral dissertation on German historical drama (Om det historiska dramat i Tyskland, [Historical Drama in Germany], 1868) Kaarlo Bergbom, founder of Finnish theatre, refers to Goethe as Germany's greatest poet (Grellmann 1948, 108). In the first season of his Finnish-language theater, founded in 1872, the repertoire included Goethe's play Die Geschwister in F. W. Rothstein's translation. Goethe's plays were staged earlier in the Swedish-language theatres: for example in the 1869-1870 season Faust was performed in Helsinki's Swedish theatre, and in 1876 Viktor Rydberg's masterful translation into Swedish was published. The translation fever that broke out in the 1870s in Finland also benefitted Goethe. Among others, Goethe translations were published by Aino Kallas' parents Julius Krohn (1835-1888) ${ }^{17}$ and Maria Lindroos-Krohn. ${ }^{18}$ Goethe's popularity in Finland also rose after his poetry was successfully put to music (Martin Wegelius, Karl Flodin). In 1884 the first Finnish-language translation of Faust was published by Kaarlo Forsman (Koskimies) ${ }^{19}$, and the first Finnish translation of a collection of Goethe's poetry was published by K. F. Ridderström. Into this Goethe-charged atmosphere Otto Manninen was born in 1872; he was to become the Finnish translator of Faust and other works by Goethe in the 1930s. Eino Leino was born in 1878, who esteemed Goethe greatly and translated him. The year 1885 saw the brith of V. A. Koskenniemi, who considered Goethe to be his 
great model. Aino Kallas, their contemporary, shared their enthusiasm and interest completely, all the more so since she was conscious of her German roots, and her origins meant a great deal to her.

Thus, Goethe was a natural part of Aino Kallas' educational background. Not only had he been the linguistic touchstone for educated Finns, but he was also the measure of Aino Kallas' own intellectual maturity. "Am I now goethereif - ripe enough to understand Goethe? So it seems: I have an irrepressible need to read Goethe; his shadow always lies across my path like the shadow of a giant tower" ${ }^{20}$ (Kallas 1953, 75).

\section{Goethe in Germany}

Aino Kallas received a proper German education. She spoke German fluently, which allowed her to read Goethe in the original; she was able to partake synchronically of contemporary German literature. Perhaps she was also conversant with contemporary Goethe reception, which allowed a range of different connections with the works of the classic poet.

Although there had been a certain ebb in the homage paid to Goethe in Germany during the era of realism, he remained firmly lodged in the core of 19 th century school reading programs. Beginning in the 1860s he was an integral part of school compulsory reading lists. There was hardly a young poet or poetess, nor a single popular novel (particularly women's novels) that did not quote from Goethe, or contain a Goethean structural element, motif, or characters (Werther in particular). ${ }^{21}$

From the end of the 19th century onward, Goethe's reputation climbed higher than ever before, and there was not a single literary movement, stylistic trend, or political view which did not attempt at instrumentalizing Goethe to some end (cf Otto 2000). Scholarly studies of Goethe were the first to take off, spurred by the opening of Goethe's literary estate in Weimar. Over the years 1887-1919, a 143-volume edition of Goethe was published in Weimar (Weimarer-Ausgabe, the so-called Sophien-Ausgabe), A Wilhelminan monument to Goethe. At the state level, the myth of the Weimar classic was created, the pinnacle of German culture obligatory for all, from which point onward there was nothing left but decline. Goethe of the classic age was the measure of all things, free both of historical connections and of ties to literary modernism. Indeed, Goethe is used as an argument against modernism, as argued Adolf Bartels and Friedrich Lienhard, theoreticians of the Heimatkunstbewegung in the series Wege nach Weimar, published 1905-1908.

This timeless myth of Goethe is supported by a wealth of biographies and popular treatments of Goethe from the beginning of the 20th century. For example, in 1912 a biography of Goethe was published by H. S. Chamberlain (Chamberlain 1912), who had already become famous for his antisemitic tract glorifying the Aryan race, Grundlagen des neunzehnten Jahrhunderts (1899). The 20th century understanding of Goethe was influenced in a major way by Friedrich Gundolf's Goethe (Gundolf 1916), which is devoid of historical connections and consists of timeless literary metaphysics. 
The most important German intellectuals defined themselves in relation to Goethe, led by Nietzsche, who saw himself as the third enricher of the German language, following Luther and Goethe, whom he deemed the best representative of Apollonian art (Böschenstein 2000). Modern literary movements encountered Goethe from different angles. The naturalists liked the young Goethe: Gerhart Hauptmann believed the German theatre should return to Götz and gather new strength from him. The expressionists were drawn to the "Sturm und Drang" era Goethe, who called attention to youthful creativity (e.g., in 1909-1912 Max Morris edited a 6-volume edition entitled Der junge Goethe, see Morris 1909-1912). In contrast, the symbolists were interested in the mature Goethe: in 1901 Stefan George and Karl Wolfskehl compiled an anthology of Goethe's poetry, containing poems from the West-East Divan, and showing Goethe as an artist of strict form (George-Wolfskehl 1901). Hugo von Hofmannsthal and Rainer Maria Rilke are also inclined to foreground Goethe's later works.

Another direction can also be discerned at the beginning of the 20th century, which opposes turning Goethe into a timeless standard, emphasizing instead his individualism and idealism, calling attention to his representation of the human as a social being. Read from this perspective, Goethe's later works, Faust Part II and Wilhelm Meisters Wanderjahre move to the foreground. ${ }^{22}$

For the philosophy of the beginning of the 20th century, which regarded self-realization and intense living as the highest human goals, the philological classification of Goethe's individual works was less important than his personal example of living with intensity, to quote Georg Simmel: "seine Existenz rein als Existenz zu möglichster Höhe, Stärke, Vollkommenheit zu entwickeln"23 (Simmel 1914).

Georg Simmel (Simmel 1913) was interested in a wholistic interpretation of Goethe's works, the spiritual meaning of Goethean existence, the "idea of Goethe". For a creator who has matured, the fulfillment of personal existence, and the shaping of the self become objective ideals - both for action and cognition. According to Simmel, the miracle of Goethe's existence is that his passionate and subjective life flows of itself into art, feeling, and into the objectively valuable results of practical action. With respect to Goethe's old age, Simmel emphasizes his objective self-existence, his desire for union with life, and his symbolic grasp of the whole content of life, all of which is borne by the life-principle "the purpose of life is life itself" 24 .

\section{"Goethe, Master!"}

"I have never learned from anyone's life, either dead or living, as much as I have learned from that of Goethe" ${ }^{25}$ (Kallas 1956, 202), notes Kallas at the end of the last diary volume published during her lifetime. Aino Kallas read Goethe's many biographies with as great enthusiasm and dedication as to Goethe's works themselves. In her diaries, Kallas mentions five names that guided her to Goethe. The first is George Henry Lewes, the champion of Goethe in England, whose Life of Goethe (Lewes 1855, German translation 
1857) shaped the Victorian image of Goethe - not so much as a promethean creator or a magical genius but as the author of Wilhelm Meister's Apprenticeship, Journeyman Years and of sophisticated maxims. The second is Paul Julius Möbius (Goethe 1903, mentioned in Kallas 1953, 167), who is known primarily for his misogynistic gender theory (Über den psychologischen Schwachsinn des Weibes, Halle 1900), and who began to discuss Goethe's male characters in terms of their "unmanliness" (Möbius 1898; cf Brandes 1922, 111).

The third and the latest guide for Kallas from her London period is popular biographer Emil Ludwig, whose Goethe (1920) was in 1928 also published in English. This work assumed importance for Kallas in 1929, when she embarked on reading Goethe again, including the second part of Faust where she stopped duirng her earlier "Goethe period".

But Kallas' earliest and most significant guide to Goethe was Georg Brandes, the literary scholar of Danish origin whose influence spread all over Europe. To Aino Kallas he was not only her teacher but the genius of the age, translator of a "critical age of breakthrough, in which the new was shaped and the old crushed" (Kallas 1953, 75). She continued, "In Brandes the small, intuitive discontentment and restlessness in all of us has found its great interpreter" (Kallas 1953, 75). ${ }^{26}$ Later, looking back on her years of searching, Kallas writes of Brandes: "In my great year of spiritual famine, he was my bread and butter, a marker and support for my youthful atheism of that time. He took me to Goethe and Shakespeare, and freed my individuality" ${ }^{27}$ (Kallas 1956, 10).

Brandes' capacious Goethe monograph was published in 1914 (Brandes 1914), but Brandes was already studying and lecturing on Goethe much earlier. In 1888-1889 he gave three lectures on Goethe at Copenhagen University (Brandes 1922, 5), but in his essay "Goethe and Denmark", which was published in 1881, he writes: "One can set Goethe in relation with every civilized people, and the stage of development of that people in the modern era can be measured on the grounds of its comprehension of that one spirit; indeed, every epoch, country, and every man can be characterized through the judgment they have made concerning Goethe" ${ }^{28}$ (Brandes 1922, V). Here Brandes borrows the word goethereif from Berthold Auerbach, thereby providing Aino Kallas with a measuring instrument of spiritual maturity.

Brandes considers Goethe to be the greatest poet of the last three centuries. But this is by far not the only thing that fascinates him about Goethe. Like Georg Simmel, Brandes is interested in Goethe's personality, the story of his intellectual and spiritual formation. Further, he considers Goethe greater as a personality than as a poet: "As a human being, Goethe, with all of his exemplum-rich life experience is greater than his own lifework, as great as that certainly is" ${ }^{29}$ (Brandes, 1922, 11). He emphasizes the deep humanness of Goethe's personality, while critiquing the idol-worship created by Goethe philologists in Germany, who elevated Goethe to classical heights. For Brandes, Goethe's personality is his greatest work of art, while his literary activities are deeply human. In Brandes' eyes Goethe is first and foremost the embodiment of the ultimate in humanness, the greatest master of self-development, who uses his experiences for the furthering of the in- 
ner life. All in him is "quiet growth, peaceful unfolding, slow re-formation, thoroughgoing rebuilding" ${ }^{\circ}$. He rules his own life completely, yet without being a narcissist: "Gazing at himself in the mirror was foreign to him, selfdevelopment was everything!" ${ }^{11}$ (Brandes 1922, 12). Don't forget to live! This, in a few words, sums up the content of several of Goethe's works. Yet, using Goethe's formula "Nur der verdient sich Freiheit und das Leben, / Der täglich sie erobern muss"32 (Goethe, Faust 11575-11576).

From Kallas' diaries, one sees yet another guide to Goethe (Kallas 1953, 203), Albert Bielschowsky, whose very popular Goethe (Part I 1896, Part II 1904, with 42 printings by 1922) brought Goethe down from classic heights and dusty shelves, emphasizing, as Brandes had done, his humanness. This is what is important to Aino Kallas as well. What fascinates her the most in Goethe's oeuvre are his autobiographical works, especially Italiensische Reise, about which Aino Kallas writes:

I truly began loving Goethe thanks to his book Italienische Reise. These are fragmentary, mostly subjective memories, but in their very momentariness full of pulsating life, and that is what brought him down from the dusty shelf of the classics into the world of the living. (Kallas 1953, 130). ${ }^{33}$

While reading Bielschowsky's Goethe, Kallas notes: “The outlines of Goethe in my inner world are becoming more and more defined - from the time I owned Goethe, the course of my development has been determined. His shining beam of light illuminates all that is unclear and clumsy in me." (Kallas 1953, 204). ${ }^{34}$ Aino Kallas does not analyze the individual works of Goethe, but rather tries to capture in Goethe the person with whom she feels spiritual affinity:

Goethe's concreteness, objectivity, harmoniousness, love of nature, and his distaste for mathematics and abstract thinking, his lack of interest in the life of political parties and questions of government, his instinct for self-preservation, which has falsely been referred to as his egoism, some horrible kind of formality - all these resonate in me as well. What of it, then, if they resound in Goethe as a great symphony, and in me very clumsily and tentatively, as inaudible single notes! (Kallas 1953, 142). ${ }^{35}$

The diaries show Aino Kallas constantly changing, open to new experiences and spiritual impulses, striving toward wholeness as a personality and a creative being. "There is no greater happiness than the development of all one's powers. To grow one's full size, so that not an inch is missing, to be perfect like a crystal! ${ }^{36}$ (Kallas 1956, 161). Aino Kallas' drive for self-development - not the acquisition of abstract knowledge, but the intensification of life through experiences - might thus be regarded as a Goetheian aspiration.

For Aino Kallas, Goethe was important both for the development of her personality and her search for form, for an escape from a "literary chaos": "Goethe does not oppress me; rather, in him and through him both my originality and my individuality find stability and clarity. He pours my 
formlessness into form" ${ }^{37}$ (Kallas 1953, 204). Under Goethe's influence the form of her own works gains clarity. Yet sensing the danger of frozen form, Kallas vows: "God, give me a living word! ... I do not want any concept to be a mere word to me, and I will not rest until it has become something entirely alive to me" ${ }^{88}$ (Kallas 1953, 131). The living word and the hatred for empty phrases are those aspects that she admires in Goethe, finding his works "full of pulsating life":

As from a horn of plenty, thoughts and images have flowed over me in their rich fullness. Now I see the world only through Goethe's eyes. I have taken him into my being directly, in a way that up until now has only been true of living people. I can feel each of his words turn into living power in me. (Kallas 1953, 128). ${ }^{39}$

The "living word" Kallas speaks of here is not an expressive outburst, a "Sturm und Drang" intoxication, but rather the objectification of experience into symbols, from which mystical power radiates. Thus it is no wonder that Aino Kallas refers to her novels as ballads, to which Goethe gave the definition that it still has today: the primal egg of poetry in which the lyrical, epic, and dramatic elements are not yet separated, and which exerts its mystical force by way of that very syncretism, which touches the core of human being.

Kai Laitinen has observed in Kallas' oeuvre a growing distance between subjective experience and its artistic execution. "...underneath the surface of the seemingly objective style of narration there is a great deal of passion, which makes itself felt above all in the rhythm of sentences, the piling up of events and details, and the intensity of images. The passion is controlled, almost cold, and yet it radiates in all directions. (Laitinen 1997, 241).40 Perhaps Kallas learned the objectification of subjective passion into art, the forming of passionate experiences into dispassionate form, from Goethe. Along with this, perhaps, finally came the balance between life and art.

Perhaps it is possible to speak much more specifically about Goethe's influence, and to extend this analysis in several directions. As Kallas herself has stated, "Goethe is a centre from whom sparks fly out in all directions" ${ }^{41}$. (Kallas 1953, 167).

\section{Notes}

1. [Niinkuin lentävä lastu on osa lakkapäästä hongasta, niin olen minäkin syvästi tuntenut olevani samaa ainesta kuin Goethe. En olisi ikinä voinut häntä niin orgaanisesti olentooni omistaa, ellen olisi samoista alkuaineista kokoonpantu. Vain siten voin selittää sen uudestaansynnyttävän voiman, mikä hänellä on minuun. Elämäni on voittanut kirkkaudessa ja selvyydessä, siitä asti kun olen tämän elävän rajamerkin tajunnut.]

2. Apparently Sämtliche Werke in 18 Bänden, published in Leipzig by Th.KnaurVerlag.

3. [Faustin tähden uneksin kokonaisen päivän ja valvoin kokonaisen yön.]

4. [...en kestänyt ylimenoa tähän kuolleeseen kirkkauteen.]

5. [Goetheen on minulla "mystillinen yhteys". Minun ei tarvitse avata hänen kirjoaan 
niistä häntä hakeakseni. Elän hänen ilmapiirissään, kuten opetuslapsi Mestarinsa.]

6. [Goethen kautta ikäänkuin synnyn uudestaan. Hän vetää koko olentoani kuin magneetti rautaa, enkä saa ennen rauhaa, ennenkuin olen kokonaan sulautunut häneen. Tämäntapaista mahtaa olla uskollinen herätys.]

7. For a closer analysis see Silja Vuorikuru's article in the same volume.

8. [Modernismin henki alkaa yhä enemmän tunkea lävitseni. Aivoni ajattelevat uudenaikaisesti, mutta tunteeni on vielä vanhaa perua. Tahtoisin ikäänkuin tehdä hyppäyksen uuteen, mutta otta liian paljon mukaani vanhasta.]

9. [Tämä on elämäni täyttymys - minun suuruudenunelmani on aina ollut olla lähellä suurta, luovaa neroa.]

10. [The gods give everything, the infinite ones/ to their beloved, completely.] These lines come from Goether's poem "Aus einem Brief an Gräfin Auguste zu Stolberg" (Goethe 1996 I, 142).

11. [Lienen sukua Yeatsille, Syngelle, kelttien hengelle.]

12. [22 vuotta takaperin makasin Nummelan alahallissa ja luin Goethea. Ja nyt istun Viron Lontoon lähetystön parvekkeella, kaksikymmentäkaksi voutta vanhempana ja taas luen Goethea.]

13. [Miksi Goethe minua yhä vielä vavistuttaa? Yhä vielä hän on elävämpi minulle kuin tuhannentuhannet elossaolijat... Kaksikymmentä vuotta takaperin hän auttoi minut löytämään itsensi; sen jälkeen on elämäni ollut yhtämittaista kasvua. Miksi hän taas lähestyy, miksi lankee hänen varjonsa taas tieni yli? Lähestynkö taas vedenjakajavaihetta elämässäni?]

14. cf closer analysis in Alttoa 1931.

15. This delay has since been compensated completely by the parallel publication of two translations, Ants Oras in 1955/1962 and August Sang in 1946/1967.

16. Kallio's translations or adaptations of Goethe's poems were published in 1832 in the journal Otava (see Grellmann 1948, 50-53).

17. The translation of the poem Heidenröslein was published under the name Suonio in 1869 in K.G. Leinberg's collection Satakieli [Nightingale].

18. The translation of the poem Gesang der Geister über den Wasser appeared in 1876 in the newspaper Pääskynen, $\mathrm{nr}$ 1, 8.1.

19. Johann Wolfgang von Goethe, Faust, murhenäytelma, Part I, Söderström: Porvoo, 1884.

20. [Olenkohan minä nyt "Goethereif” - kypsä ymmärtämään Goetheä. Tuntuu siltä, minulle on suora välttämättömyys lukea Goetheä, hänen varjonsa on aina tielläni kuten jättiläishuipun varjo.]

21. For more details, see Landfester 2000.

22. Wilhelm Meisters Wanderjahre is mentioned in Protestantische Ethik und der Geist des Kapitalismus, the work published in 1905 by the founder of sociology, Max Weber. Faust Part II is central to Ernst Cassirer's work Idee und gestalt, Goethe, Schiller, Hölderlin, Kleist (Berlin: Bei Bruno Cassirer, 1921)

23. [ ...his existence as having the goal of developing living to the highest degree, power, and fulfillment.]

24. [Der Zweck des Lebens ist das Leben selbst.] Goethe, Letter to J.H. Meyer, Weimar, 8. II 1798.

25. [En yhdenkään ihmisen, en kuolleen enkä elävän, elämästä opi niinkuin Goethen.]

26. [Brandes on ajan nero: arvostelevan, uusia hahmottelevan, vanhaa repivän ajan, murrosajan tulkki... Brandesissa on meidän jokaisen pieni, aavistava tyytymättömyytemme ja rauhattomuutemme saanut suuren tulkintansa.]

27. [Suuren henkisen nälän vuonna hän oli minulle leipä ja särvin - tienviitta, tuki silloiselle nuorelle ateismilleni. Hän vei minut Goethen ja Shakespearen luo, vapautti yksilöllisyyteni.]

28. [Man kann Goethe in Verhältnis zu jedem zivilisierten Volk stellen, und würde 
die Entwicklungsstufe dieses Volkes in der modernen Zeit an dem Grund seines Verständnisses für diesen einen Geist ermessen können; denn jede Epoche, jedes Land und jeder Mensch charakterisiert sich selbst merkwürdig durch das von ihnen über Goethe gefällte Urteil.]

29. [Als Mensch ist Goethe mit seiner beispielgebenden Lebensführung überhaupt grösser denn sein Lebenswerk, so gross dieses auch ist.]

30. [...stilles Wachtstum, ruhige Entfaltung, langsame Umbildung, durchgreifende Umschaffung.]

31. [Selbstbespiegelung war ihm fremd, Selbstentwicklung alles.]

32. [He only earns his Freedom and Existence, / Who's forced to win them freshly every day.]

33. [Rakastamaan Goetheä olen ruvennut oikeastaan vasta hänen "Italienische Reise" kirjansa ansiosta. Nämä katkonaiset, mitä suurimmassa määrin subjektiiviset muistelmat, mutta silmänräpäyksellisyytensä tautta täynnä sykähtelevää elämää, ovat tuoneet hänet minulle takaisin klassikkojen pölyiseltä hyllyltä elävien maailmaan.]

34. [Yhä selvemmiksi piirtyvät sisäiseen maailmani Goethen ääriviivat - siitä asti kun olen omistanut Goethen, on kehitykseni ollut määrätty. Kaiken epäselvän ja hapuilevan kirkastaa hänen valonheittäjänsä.]

35. [Goethen konkreettisuus, objektiivisuus, harmoonisuus, rakkaus luontoon ja vastenmielisyys matematiikkaa ja abstraktista ajattelua kohtaan, hänen vähäinen mielenkiintonsa puolue-elämää ja valtiollisia kysymyksiä kohtaan, hänen egoismiksi väärin nimitetty itsesäilytysvaistonsa, jonkunlainen jäykkä muodollisuus - kaikki nämä kielet soivat minussakin. Mitä siitä, että ne Goethessä soivat suurena sinfoniana ja minussa hapuilevina, aavistavina, minnekään kuulumattomina yksityisinä säveleinä!]

36. [Ei ole suurempaa onnea kuin kaikkien kykyjen kehittäminen. Kasvaa täyteen mittaansa ilman vaaksankaan vajavuutta, täydelliseksi, niinkuin kristalli.]

37. [Goethe ei muserra minua, vaan hänessä ja hänen kauttaan lujittuvat ja selkiävät erikoisuuteni ja individualiteettini.]

38. [En tahdo, että mikään käsite pysyy minulle pelkkänä sanana, en lepää ennenkuin se on minulle täysin elävöitynyt.]

39. [Kuin runsauden sarvesta on ajatuksia ja kuvia ylivuotavana rikkautena tulvinut ylitseni. Näin maailman nykyään vain Goethen silmin. Olen hänet välittömästi vastaanottanut olemukseeni, niinkuin tähän asti ainoastaan eläviä ihmisiä. Tunnen, että hänen joka sanansa muuttuu eläväksi voimaksi minussa.]

40. [Juba novelli esimeses osas ... on kummalist pinnaalust kirge, mis ilmneb eelkõige lauserütmis, sündmuste ja detailide kuhjumises, kujundite intensiivsuses. Kirg on talitsetud, peaaegu külm, kuid ta kiirgab kõikjale.]

41. [Goethe on keskus, josta lähtee säteitä joka suuntaan.]

\section{References}

\section{Research Objects}

Kallas, Aino 1953: Päivakirja vuosilta 1907-1915. [Diary from the Years 1907-1915.] Helsinki: Otava. 
Kallas, Aino 1954: Päivakirja vuosilta 1916-1921. [Diary from the Years 1916-1921.] Helsinki: Otava.

Kallas, Aino 1956: Päivakirja vuosilta 1927-1931. [Diary from the Years 1927-1931.] Helsinki: Otava.

\section{Research literature}

Alttoa, Villem 1931: Goethe eesti kirjanduses: magistritöo. [Goethe in Estonian Literature.Unpublished MA Thesis] Tartu.

Bielschowsky, Albert 1896-1904: Goethe: Sein Leben und seine Werke. Vol 1-2. München: Beck.

Böschenstein, Bernhard 2000: Die Prinzipien von Georges und Wolfskehls. Kanonisierung Goethescher Gedichte. In: Bernhard Beutler \& Anke Bosse (eds.), Spuren, Signaturen, Spiegelungen. Zur Goethe-Rezeption in Europa. Köln,Weimar,Wien: Böhlau Verlag.

Brandes, Georg 1922: Goethe. Berlin: Erich Reiss.

Brandes, Georg 1914: Wolfgang Goethe. Vols. 1-2. Kristiania: Gyldendal.

Chamberlain, Houston Stewart 1912: Goethe. München: Bruckmann.

George, Stefan and Wolfskehl, Karl 1901: Deutsche Dichtung. Goethe. Vol 2. Berlin: Blätter für die Kunst, Bondi.

Goethe, Johann Wolfgang von 1996. Werke. Hamburger Ausgabe. München: C.H. Beck.

Grellmann, Hans 1948: Goethes Wirkung in Finnland. Von Porthan bis Lönnrots Tod. Helsinki: Suomalaisen Tiedeakatemian toimituksia B LXI, 3.

Gundolf, Friedrich 1916: Goethe. Berlin: Bondi.

Landfester, Ulrike 2000: Inen, Trinen, Etten und Ilien. Goethes Wirkung auf die Literatur von Frauen in der ersten Hälfte des 19. Jahrhunderts. In: Bernhard Beutler \& Anke Bosse (eds.), Spuren, Signaturen, Spiegelungen. Zur Goethe-Rezeption in Europa. Köln-Weimar-Wien: Böhlau Verlag.

Laitinen, Kai 1997: Aino Kallas. Uurimus Aino Kallase loomingu peateemadest ja taustast. [Aino Kallas. A Study on the Main Topics and Background of her Work.] Tallinn: Sinisukk.

Lewes, George Henry 1855: Life of Goethe. London: Smith, Elder, \& Co.

Ludwig, Emil 1920: Goethe. Geschichte eines Menschen. Stuttgart: Cotta.

Möbius, Paul Julius 1898: Über das Pathologische bei Goethe. Leipzig: J. A. Barth.

Möbius, Paul Julius 1903: Goethe. Leipzig: J. A. Barth.

Morris, Max 1909-1912. Der junge Goethe: Neue Ausgabe in 6 Bänden. Leipzig: InselVerlag.

Otto, Regine 2000. Editionen als Instrumente der Goethe-Rezeption. In: Bernhard Beutler \& Anke Bosse (eds.), Spuren, Signaturen, Spiegelungen. Zur Goethe-Rezeption in Europa. Köln, Weimar, Wien: Böhlau Verlag.

Simmel, Georg 6 August 1914: Goethe und die Jugend. Der Tag No. 395, Ausgabe A, Abendausgabe.

Simmel, Georg 1913: Goethe. Leipzig: Klinkhardt \& Biermann. 


\title{
Does Love Have An Essence?
}

\author{
Existentialist Remarks on Aino Kallas' Prose Ballads ${ }^{1}$
}

The four stories by Aino Kallas, Barbara von Tisenhusen, Reigin Pappi [The Rector of Reigi], Sudenmorsian [The Wolf's Bride], and Pyhän joen kosto [The Revenge of the Holy River], often subsumed under the common denominator of the prose ballads, are usually considered to be the most full-scale completions of Kallas' artistic ambitions. ${ }^{2}$ In the present article I propose to offer some remarks on the stories from the viewpoint of existentialism, focusing especially on the motif of Eros the Slayer, which looms significantly in the first three works. To avoid the charge of gratuitousness, induced possibly by a too-bold existentialist encroachment on Kallas, I wish to spell out two arguments. First, by the notion existentialism, I refer to the various intellectual traditions of the $19^{\text {th }}$ and $20^{\text {th }}$ centuries whose common characteristic was the foregrounding of the concept of freedom, as set against Naturnotwendigkeit [natural necessity] and whose one source must be situated in the Kantian fundamental distinction between the realm of theoretical knowledge, i.e. of natural causality, and that of practical reason, i.e. of morality and freedom. ${ }^{3}$ Furthermore, by some casual insights into the history of existentia I wish to provide background for understanding the even deeper theological (Christian) roots of existentialist thinking, which would hopefully afford us some crossover intuition about the knots and snarls of philosophical language. Second, as is well known, existentialism can roughly be grouped into two different branches: into the religious existentialism (Søren Kierkegaard, Gabriel Marcel, Karl Jaspers), banking on the nothingness as a source of our transcendent experience of the God, and into atheist existentialism (Friedrich Nietzsche, Jean-Paul Sartre, Simone de Beauvoir, partly Martin Heidegger) which builds onto the same nothingness its ambitious project of a free, self-constituting man. It is my firm conviction that this forking of existentialism beyond nothingness brings us right to the symptomatic spot of Kallas' art, namely to the place where she had to take some fundamental decisions on the content of human freedom and its relatedness to God. ${ }^{4}$ 


\section{The background of existentialism}

To start, I would first wish to provide some clues for situating the whole issue of existentialism into the background, which constitutes in my view a kind of pre-given field for all existentialist moves. The celebrated thesis about "existence preceding essence", made into a catch-phrase by Sartre (Sartre 1968, 17) and underpinning much of the socially orientated existentialism of the $20^{\text {th }}$ century, has lent itself easily to various postulates of individual freedom, but not very often has the route by which the idea made its way into Western philosophy been scrutinised. The best guide for accomplishing this task is the history of Latin existentia which takes us, by its formative years, back somewhere to the $4^{\text {th }}$ century $\mathrm{AD}$, to the time when some substantial conceptual struggles of Christianity were under way. In the course of these pivotal clashes of arguments (from the viewpoint of theology), there emerged in Western thinking the idea of existentia as that kind of being which defies conceptualization (essentialization), because any concept - a definition of the essentia of something - would imply laying a restriction on God's potency and freedom. Whereas in the Greek polytheistic tradition the explication of a God by reference to his/her field of action or of patronage intimated no contradiction in terms of religiosity, the application of One God in monotheism strictly ruled out any possibility of such explanative enterprise.

This break in tradition was accompanied by another significant conceptual shift, because the existentia as a pure indefinite being assumed in due course a very un-Greek quality of infiniteness, gearing up the Western mind, in broader perspective, for the extrication of apeiron from its characteristically Greek horror and loathing. Exactly for the reason that existentia came to be paired with infinity - and the tandem itself was designed to the core vehicle of the knowledge about God, shrouded often in the Middle Ages, as we know, in the verbal labyrinths of negative theology - so infinity was spurred to the entrance of the theological and, at least indirectly, of the epistemological glossary of Western thought. Hand in hand with the rooting of existentia, with its new value of ontological meaning, the establishment of another later central existentialist notion took place. The subject matter is, of course, freedom, because, despite the high place it held in the Greek philosophic agenda, freedom experienced a radical change in content in the monotheistic system of thought. Similarly as the pure infinite existentia was not elaborated by the Hellenes, freedom was never postulated by the Greeks with such vigour and absoluteness as it was in the culture governed by One God. This is best exemplified by the fact that in Greek philosophy one part of the world, namely the matter, is a strict opposite concept to a form or idea, and always to a degree outside the volitions of God, maintaining its dualistic and evil nature. The Christians succeeded in escaping the perception of matter as evil, manifestly by submitting all worldly existence to the creative act of the God which could, accordingly, operate only by "nothing". In other words, the dogma of creatio ex nihilo, stating explicitly that not even matter had come into being without the will of the God, became at the same time an announcement of the freedom of One God. ${ }^{5}$ 
To the extent we remain in the confines of the Middle Ages, where the existential factor and infinity were always considered in association with God, the question of infinite portion in human knowledge may be not so urgent. But transgressing the border of the modern age, characterized by an expressed search for the experimental witness of knowledge, the problem of the meaning of infinity surfaces beyond doubt. To adduce only some examples, the invention of the so-called points at infinity in the Renaissance painting, where artistic pursuits intermingled indistinguishably with mathematical ones, was surely backgrounded by the attempt to find representational equivalents for the God who is, according to Nicholas of Cusa, the herald of modern ages, infinite and impelling into coincidence all factual opposites. The theory of points at infinity underlay not only the artistic schema of geometrical perspective, a technical discovery of early modernity, but had also obvious implications for stimulating further evolution in geometry, resulting in the postulate of non-Euclidean models of space (Damisch 1994, 387-388; Field 1997). The second example, related also to the spatial representation, is offered to us by Isaac Newton who proposed the revolutionary idea of absolute space based greatly on deliberations of a theological nature (see Koyré 1965, 86-114). These examples illustrate how the idea of pure infinite being, or Dasein, a kind of self-enclosed negativity that lays the venue for all enunciative activity, prompted discoveries carrying the undeniable signature of modernity. The amazing and remarkable thing is that while the image of One God, conceived as a vast expansion or an immeasurably remote point, hovered above these physical and mathematical inventions, the inventions themselves, once made, drove the idea of God into oblivion - or rather, they came to be reckoned as explanative substitutes for God, invalidating religious and theological content (see Koyré 1965; Gay 1996, 140-150; Grant 1999, 240-255). The question to be posed here in a logical way is: if the debunking of theological content, affected in the course of these inventions, was a legitimate result of thinking, was atheism an unavoidable outcome of it?

The question drives us right into the focus of the events that took place in the second half of the $18^{\text {th }}$ century, namely to the Kantian distinction between theoretical and practical reason where the latter was furnished, in the form of morality, with equipments for enabling man to communicate with the noumenal realm, i.e. with the "things in themselves". Because noumens, as opposed to the phenomena with which theoretical reason operates by the aid of the established laws of natural causality, are carriers of the deepest secret of existence (i.e., of freedom), so also morality, which bases itself on the law of freedom, is a kind of manifestation of the noumenal aspect of human existence - or to say it succinctly, of a human's free will. It is pertinent as well as necessary to remark that in the background of these Kantian groundbreaking discriminations continues to figure the old differentiation between two kinds of being, because Kant lets us to recognize that the difference between existence and predication must be held onto with full force. Conceptual knowledge (begriffliche Erkenntnis), argues Kant, is attained by the way of determination, that is, by attaching predicates to the thing and by appointing the verb "be" the role of copula; Dasein is rather the "abso- 
lute position of the thing itself" (Kant 1977, 635), linked to simple perception (Wahrnemung) or intuition (Anschauung), which represent failure in terms of knowledge but which in fact precedes conceptual language as its origin (see Frank 1997, 670-674). In some German usages the perception of existeniality came to be likened to intellectual intuition (intellektuale Anschauung) - a term whose application to human intellect was rejected by "Critical" Kant. What matters from our point of view is that by these distinctions Kant drove a wedge between the knowledge afforded us by our reason (and anchored, in sum, in our senses) and the super-sensible obligation of morality which grants us intimations about the realm which entirely surpasses the limits of our empirical ego. The encouragement for integrating the existential factor into the system of knowledge, which had according to my claim motivated some fundamental discoveries of modernity, was by that move disposed of, and the job of dealing with existence was entrusted to the various disciplines (of arts, morality and philosophy) ambitioning no experimental proof of its content.

In specific historical terms we are talking about events happening somewhere at the turn of the $18^{\text {th }}$ and $19^{\text {th }}$ centuries, when the Romantic theory of art got its preliminary footing in the works of German thinkers. Without doubt, there exists a clear linkage, as demonstrated by Manfred Frank, between the Kantian existentielles Sein and the Romantic investment in the Gefühl which entailed a positing of self-consciousness onto the ground of a pre-conceptual texture and, accordingly, of non-representability. As a consequence, the meaning of infinity, which had enthralled the modern man by its implication of some absolute new experimental knowledge, was now reinterpreted in a manner of human's internal drive of freedom - that is, infinity became her/his commitment ("a yearning for the infinite") to surpass perpetually, in the form of faith, art and morality, the finite framework of our cognitive capabilities. On the other hand, Kant's distinction holds its hand out to the strictly modern existentialism, because it surely provided Søren Kierkegaard with efficient means for substantiating the irrationality of faith (cf. Kierkegaard's "leap of faith") and the deeply personal nature of a true religious experience. The Kantian disentanglement of existence and freedom from knowledge, retaining, nevertheless, their attribution to God, was followed by yet another disentanglement inside the modern existentialism which emptied the two concepts of their religious references and transposed the whole matter, articulated by freedom and existence, into the entirely human register. To say in a Sartrean way that existence precedes essence, means, first, that human is born free and that all essential determinations are ascribed to her/him in the course of the socialized selfconceptualization, and, second, that human consciousness (called by Sartre being-for-itself) acts primarily out of nothingness and is constituted by the law of indeterminacy.

My argument runs that together with disintegration of the discourse on existence and freedom from their divine tenor got lost, in the corridors of the $20^{\text {th }}$ century existentialism, as well the idea of love as a coronal accomplishment of any existential task. ${ }^{6} \mathrm{On}$ the one hand, when freedom and creation from nothing are to be understood as moments of the operational 
system of my consciousness, and, accordingly, are not to be deduced from the qualitative specificity of God - the summit of all Romantic and early existentialist love fancies - then also should love, because of the vanishing of its outermost desideratum, abdicate its responsibility for combining immanent and transcendent. On the other hand, in the milieu of downgrading of society into the contentious execution of individual projects of separate consciousnesses, where phenomena (the essentialized beings-in-itself) are deprived of their references to some deeper meaning, as they were supposed to be earlier in history, and also, where the whole multitude of human relationships, including love and sex, are projected into this battle-field of necessarily combating "freedoms", there has been left no seat for love to take. However, to draw from here a conclusion that the modern theories of de-essentialization and of respective foregrounding of existence have had a pernicious impact on love would be a serious misinterpretation of the matter. Because it would in no way explain why love thrived in the theological enterprise of existentia I have tried to sketch briefly.

To clarify, I make here my last two points. First, we have to be aware that the problem of existence, which has sometimes been propounded as a novel discovery of the $20^{\text {th }}$ century existentialism and feminism, has a long history dating back to the $4^{\text {th }}$ century AD. The concept of existentia, achieved out of the theological attempts of Christianity to expound the monotheistic concept of God, must in heuristical terms be included in the range of the theologico-philosophical pursuits, be it ancient or Christian, which tried to offer a conceivable answer to the question: what is One and how to speak about it? In other words, existentia emerged from the demand and wish to retain a henological aperture in the epistemological picture of the world. Second, we have to reveal a facet of Christian existentia, kept in secrecy so far but offering a telling explanation for why existentia integrated so smoothly, in its religious forms, the idea of love. Namely, as corollary of the fact that Christian monotheism conceived God, in a paradoxical and unprecedented way, as a Trinitarian entity, Christian existentia, or infinite being, was never considered separately from its substantially finite appearance, manifested in Christianity first of all in Jesus Christ, the Son of the God. The equal and simultaneous conflation of existential and essential being furnished, in my opinion, the power for Christianity to inspire the search for the new abiding forms of the existential factor. Coming to the Romantics' way of treating the love, we see that it was just the intermediary work of conciliating the infinite drive with the finiteness of the world that was accorded to love (see e.g., Frank 1991, 460-461).

Love's lost strength in $20^{\text {th }}$ century existentialism cannot thus be imputed simply to de-essentialization. There is a good reason to believe that the demolition of the religious field of signification that used to locate the premises of existential thinking induced the expulsion of love. Restricting the implementation of freedom and existence, destined historically to regulate our discernment of the One, solely onto the level of individual consciousness extinguished the trajectory between uniqueness and multitude that love used to move on. Surely, in a sense, it is right to say that anti-essentialism has had an immensely curbing effect on love because when love reveals itself 
inevitably as a struggle of freedoms, and when there is even nothing to be in love with, the debasement of its value is perforce included. But in fact, I think, the truth is situated on the other side of the coin. The reduction of the issue of existence onto the plane of human consciousness entails actually a substantial loss to the idea of existence, not to that of essence, because the discourse about the pure being simply cannot be unrolled in solely human terms. Much of the statements made against essentialist attitudes must in fact be categorized as weak, because they introduce and inscribe in rebounding manner the positions they are fighting against. ${ }^{7}$ The elimination of the transcendent clues of discourse makes it impossible to sound the truly existential string of human thought and consequently, we can say, love is killed not by a surplus of existence but by its factual meagreness.

\section{The prose ballads in the light of existentialism}

Let us allow the canvas, on which we hope to make appear the existentialist draft of Kallas, to be held, metaphorically, by three hooks, represented by our previous discourse as litmus papers of existentialism: freedom, love and nothingness. Probably, without need of further explication, we are entitled to say that all the protagonists of the three stories under discussion, Catharina Wycken, Barbara von Tisenhusen, and Aalo, are breaching, in their major actions, the roles accorded them by their social space. That is, they make a decision to defy certain communal rules, manifesting thereby their personal freedom and self-consciousness. Catharina Wycken realizes her freedom by interpreting the Song of Songs, not in its traditional allegorical meaning, but in a direct sensuous way, as if warranting her love for Jonas Kempe; Barbara von Tisenhusen does it by ignoring the rule of purity of blood; and Aalo, in a more mysterious way, by becoming identified in her fantasies (or in those of the storyteller and the people) with wolves. Following the line of our previous thought, the compulsory question to be asked is, what kind of freedom have we to do with in these three cases - is it relative freedom, tied to the conditions, or is it an absolute one, a freedom born out of nothingness? The question is in fact already responded to by the common tag stuck to the stories, Eros the Slayer, which tell us, first, that the freedom these women discover is an outgrowth of love, or the converse, and second, that the love, although stimulating a self-conscious act of breaking impersonal rules, is doomed to failure by interrupting the life of its enactor. While the proper existentialist (Sartrean and, say, feminist) positioning of the matter should demand that freedom is discovered in the cavity of nothingness and, as such, freedom provides basis for the project of self-execution, Kallas, we must say, stops halfway, because the feminine freedom she offers is found through love, or at least, the two cannot be severed from one another.

In this sense, Kallas' freedom remains rather incomplete, since actual freedom should wipe away love as an inevitable restriction of liberty. As concerning the third supporter of our canvas, nothingness, we could guess that the pairing of freedom with love leaves Kallas unfamiliar with the depths of nothingness, but at this point I wish to draw attention to the detail 
which will possibly, I estimate, tell us something characteristic about Kallas relationship to nothingness. Namely, it is noticeable that although the main topic of the stories is love as experienced by woman, we in fact learn very little, or practically nothing, about the content of that love. We are persistently presented this love as seen and experienced by the outward viewer and teller. Yes, it has been argued that The Wolf's Bride is out of line in this respect (Laitinen 1995, 248-255), but I am not sure that Aalo's described experiences in wolf's skin should be viewed as a shifting of focus from a storyteller's consciousness to that of the female protagonist; rather I would argue that the storyteller represents there his own witch-hunt fantasies. From this point of view, the main theme of the stories, which could be called freedom experienced as love, has itself been represented as an emptiness which could only be perceived through the waves it generates in the outside world (in the storyteller).

However, the nothingness in the stories, we can argue as well, is captured by Kallas in the ineluctable move of her female characters towards the tragic end of their life - that is, towards nothingness not as something to be perceived but as something to be melded with. The combination of female love with death figures so pervasively in the works of Kallas that a different outcome is really unimaginable. Taking this fact into account, we can construct ourselves a preliminary configuration of the three existential notions, as seen in the mirror field of Kallas' prose ballads. The reason these works exist, their point of initiation, must be located in the experience of women's falling in love, which is depicted in the stories not as a personal activation of certain emotions and thoughts but as an act, on the part of woman, intended to flout certain aspects of social discourse. We as readers do not know why the women love and what they love, but we witness the outburst of emotions and thoughts induced by their love in the consciousness of other persons. Inasmuch as the women remain confident of their love on the plane of their decisions - and they surely do because they make a choice to die in the name of it - their love, as defiance of social causality, must be considered an act of freedom. Yet, as this freedom is not born out of nothingness, the only legitimate foundation for anyone to ground his or her actions on, but is, on the contrary, a result of an (psychic, sexual) affiliation to another person, the freedom should be called inauthentic. It fails to include nothingness as fundamental motif of consciousness and comes to the adjacency of it only at the irreversible event of death.

However, once again we must insist that there is a trick played on us on the level of representation: although love should, according to our presuppositions, be viewed as an attraction for essences which spoils the elegance of a "decision out of nothing", Kallas exhibits a stunning nonchalance about the love itself. Her representation clears love away, equates it with a blind spot to be noticed only by the agitation it stirs up in its surroundings. Thus, for example, the beginning of Catharina's adulterous feelings is described through the eyesight of Paul Lempelius:

... her grey eyes glittered like the surface of a stream, and never before had I seen her so merry and full of laughter. Of her pretty tricks there was no end, 
and when she sported with Deacon they were like two gambolling children, and Catharina Wycken suffered him to teach her the newest songs, which they sang together then and there, for Catharina Wycken had a clear and ringing voice. But in my heart a faint unrest began to dawn, as in the juice of currants when gathered in vessels and put to stand under a covering. (Kallas 1975, 94-95.) ${ }^{8}$

Can we infer from it that love for Kallas is really a love to be infused with the non-being of things, which would explain also why it is so massively covered up by an author? I think the right thing to be said at the moment is that Kallas' characters do not destroy essences in the name of achieving their absolute freedom and indeterminacy. Their diving into love betrays an emotional commitment to the world where freedom, ensuing from love, is manifested for the sake of retaining magic physical bond with the loved one. Barbara's exposure of her freedom (from the law) coincides quite exactly with her manifestation of love:

And, rising, she answered again, and she no longer wept: "I will not be divided from Franz Bonnius, though I were to die the death of hunger for his sake." And I saw then in her eyes that this was her true and firm resolve, and that she was ready to give up her life for this man and to die with him. (Kallas 1975, 28.)

As to the question of why love proves to be so tragic and why Kallas accords so little attention to its symptoms in women, the possible answer may be found elsewhere. It is my conviction that the works of Kallas, and especially her prose ballads, testify to a belief that love always entails a demand to transgress the borderline of a perceptive me for the simple reason that the topic of love is not expressible within the extension of a mind of a person. The tragic outcome of stories, which can be imputed to the social and ideological prejudices of the milieu depicted, is in my view readable also as Kallas' persistent attempt to shift the representation of love out of conscious, that is, to the existential plane - to where the meaning of love can be intuited only through the religiously peaked animation of human relationships and environment.

To bring the matter under discussion into better relief I would like to juxtapose The Rector of Reigi with an Estonian story from approximately the same period by an author with whom Kallas had throughout her life close collegial and personal contacts. I have in mind Friedebert Tuglas' short story "Maailma lõpus" [At the End of the world] from the year 1917. The kernel of Tuglas' story is a mythologically underpinned journey to the island at the end of the world, where a young man, a member of the crew, comes to experience a frantic love affair with an inhabitant of the place, a giant maiden. The two stories have conspicuous points of resemblance: in both cases the storyteller, or male protagonist (Paul Lempelius and the lad respectively), leaves the centre for a kind of insular periphery dubbed by Kallas and Tuglas equally finis terrae, or the end of the world; also, on the island the male protagonists come across eros which proves to be totally incompatible with their languages - in the case of Tuglas, with human language in general, in the case of Kallas, with the language of a protestant pastor; third, the con- 
flict leads to the slaying of female person(s) instigating eros - Tuglas' male character commits it by his own hands, Lempelius by submitting himself to the law and to the will of the court; and finally, both stories are written in the first person as records of the storyteller's direct experiences.

At this point I cannot help referring also to certain similarity of the stories in their use of elements, which possibly bear relevance to some mythological origin. The protagonist of Tuglas' story claims to be gliding "like a swan on the lustrous surface of her [giant maiden's] eyes"10 (Tuglas 1982, 75-76), and this description proves to be significant, considering that the Estonian astral and solar mythology, of which the story makes good use (see Undusk, R. 2005, 134-135), has been related by some mythologists to the Indo-European pedigree (see Puhvel 1965, West 1975), i.e. to the story of Greek Helen who was born out of the union of swanlike Zeus and Leda. Now, the coupling of Kallas' female protagonist (Catharina) with a swan possesses a highly significant place in the emplotment of the whole story: the evocation of Catharina to her husband in the form of a swan pertains to the crucial event in the beginning as well as in the end of the tale. Being unaware of any direct relatedness of the two women in Kallas' mind, I cannot restrain from feeling that Catharina's decamping from her husband repeats somehow the mythological elopement of Helena with Paris.

A salient difference, juxtaposed with these similarities, is that Tuglas concludes his story by leaving the male character in utter indecision and despair, while Kallas allows Paul Lempelius to achieve a state of composure through his newly achieved (possibly spiritual) field of communication with Catharina Wycken. However, the most significant divergence is that while Tuglas' storyteller offers us a gamut of descriptions on the sensual, including the sexual side of his love, Kallas has in the same conclusive manner excised that possible aspect of the story. In more general terms the story by Tuglas has been characterized as an experimental attempt in Estonian literature to represent a relationship between woman and man in a situation where they have been dispossessed of a common sign system, i.e. of language - with the result that they find themselves inhabiting a paradisiacal setting where action itself proves to be the only way of communication and where, therefore, even an inkling of a lie is excluded. Exactly this status of each person being an actor of a word, in the sense of being a creator, revoking any possible detachment of a thing from a sign, has warranted an opinion of Tuglas' story as an endeavour to assay some existentialist presuppositions in the climate of art (Undusk, J. 2005, 205). The conclusion he seems to offer is that, although "the end of the world" fills one's heart with desperate and unquenchable yearning, life in a signless world is unbearable and invokes perforce murder as an implement for disrupting, by introduction of a mark of meditativeness, the flow of sensuality.

In spite of the fact that Kallas avoids bringing us to the closeness of noumenality focused on by Tuglas, her characters are destined, interestingly, to undergo the same dreadful experiences. Like the giant maiden, they are doomed to disaster, although, unlike the former, they court tragedy by infringing on certain laws which may intimate, in a very remote perspective, the signless freedom of Tuglas, but in any case fails to touch it. Even 
more interesting is that while the giant maiden can surely be said to embody the unrestricted opulence of nature, Kallas too, without doubt, pairs the catastrophe of her women with their naturalistic taste, but does it in a register deviating greatly from Tuglas. While Tuglas' storyteller comes to meet nature in his female partner in a form of wildness and ferocity, Kallas presents the perception of woman through nature as an apogee of man's cognitive struggles, which simply must, because it reveals the impersonal psychic texture of being, convey a meaning of transcendence. To answer the question of what are the aesthetic key points of the prose ballads, I would surely say that they are situated in places where the male characters, who had fostered the death sentence of women, achieve through the doubling of woman's personality in marks of nature (be it wolf or swan) a restoration of the continuity of being they had checked by the discreteness of their judgement. And this restoration bears in Kallas obvious notes of concern about religiosity of being. I think the best example of the situation is provided us by The Wolf's Bride where Priidik comes, after his wife Aalo had been burnt as a werewolf in the bath-hut on his indirect approval, to experience a curious mixture of cumbersome feelings which he succeeds to discharge only by shooting a wolf - perceived by him as an embodiment of Aalo's roaming spirit - with a silver bullet.

And a great longing possessed him to see once more this wolf, which had escaped his bullet on Kassari Island. ... And now nothing was dear to him any longer, neither prosperity nor earthly happiness, but night and day he thought only of this one forest wolf, in whose shape the soul of Aalo his wife still roamed, powerless to break the spell that bound her spirit. ... And often at night, in his dreams, he seemed to see the same wolf standing in his path as he roamed the forests, gazing upon him with eyes of great mournfulness, as though an imprisoned soul was awaiting deliverance. And at last he could no longer bear this anguish of his soul, but it grew beyond his strength, like an over-heavy burden. So one morning he sought out the silver wedding-ring which the Rector of Pühalepa had once placed on his finger before the altar in token of the holy estate of marriage. (Kallas 1975, 215-216.) ${ }^{11}$

The last chapter of The Wolf's Bride, the subject of this episode, spins together in a miraculously beautiful way the different strands of the story, involving as central motif the continuous and developing entanglement of Aalo with the sheep. The story had begun by telling us how Priidik had met Aalo the maiden while she was washing the sheep in the sea; the next stage in this line of events is marked by her becoming a werewolf and wolf's bride with an indictment of stealing the lambs; the finale is reached when Priidik, to appease his sorrow for the dead Aalo's anxious spirit, whom he had again recognized in the "wolf attacking sheep", casts his wedding-ring into a silver bullet and discharges it off to the heart of the wolf. The burning of the latter, a kind of repetition of Aalo's auto-da-fé, accomplished now by Priidik for saving her spirit from possession by the Devil, is filled with an emotional ambiguity that in my opinion only adds up to Kallas' artistic intentions on love. 
What I am purporting to say is that this disastrous way of loving must be seen as Kallas' manner of leading man's perception of love to the register where woman starts to figure for the continuity of life not in terms of physicality but, first of all, of anima. Surely, the death sentence the men (be it Lempelius, Priidik, or Jürgen von Tisenhusen) connive at, or even themselves execute, can be interpreted as a kind of taking of a decision which, as the word (decido) itself says, means cutting off a part from something more complete. In this sense, a passing of a decision is also a sort of producing of a definition. And as we know from what was said earlier, definition is by its nature very un-existential because it tends to give us a positive core - an essence - of something. In its depth structure, decision always commits a murder because it excludes, on account of being a definite thing, its possibility of being something other. At the same time, the killing of a sinning woman acts as if to release her soul and brings about a prolonging of her existence in other forms of reality - which I deem to have been the most secret wish of all Kallas' women, to the degree that I feel them laughing for joy at the moments of their animal doubling because this is when the love, as they have desired, has been born:

But as I looked upon the dying swan, terror overcame my spirit, and the hair bristled on my head, as though a ghost had passed by me. For from the eyes of the dying swan, the eyes of my wife Catharina looked forth, as they had looked at me in her virgin youth, shy and dreaming and as though appealing for mercy. ... And I moaned and cried aloud: "Woe unto thee, Catharina Wycken - why hast thou left me, why hast thou forsaken me? Lo! They have laid hands on thy white neck and severed it with their swords." And now only was it borne in upon me all too clearly that I had never ceased to love this woman. (Kallas $1975,147-148.)^{12}$

To put it briefly, while Tuglas' journey to the end of the world, as a kind of emptying of signs, leads to voluptuous and devouring nature, necessitating murder as a way to inhibition of its sensual opulency, the killings of Kallas too, we can say, are executed for the consistency of manly discourse. But the vector attached to them is completely different from Tuglas. Namely, they all lead in the last resort to a rather benevolent and merciful nature, a concept, which remains undiscovered for Tuglas. Expressed in more specific terms, Tuglas achieves the sense of existentiality out of the annihilation of signs, revealed ultimately as savage eros, whereas Kallas leaves us only to guess the ferocity of eros and plays the existentiality out as a last step after the resources of signs have been exhausted. The difference in the direction is accompanied by the fact that the feeling of internal linkage of human psyche with nature is displayed by Kallas in a key that leaves no doubt about its reference to divine intention. The overcoming of the disruption, introduced necessarily by human cognition, means for Kallas not a face-to-face meeting with the immediate instinctivity of nature, but, rather, she gives us a hint that there is a process of intelligence in nature because it follows, as also human thought, a more general plan of the God. Nature and human thinking then stand, according to Kallas, in certain complementary relation, and the 
existentiality of being reveals itself as the incomprehensible glory of God repairing the disjuncture introduced by thinking.

I hold that the desolate condition Tuglas leaves his storyteller in after committing a murder and escaping from the island exemplifies well, compared to Kallas' more promising finales, Tuglas' reluctance to commit himself throughout all his oeuvre to some religiously underpinned outlook. Rather, Tuglas seems to fancy in his works the idea of writing a kind of apology of devil, represented metaphorically in the image of the Cross carrying skeleton of an ape (see Tuglas 2007). As a consequence of this lack of, say, transcendent perspective in Tuglas, an amount of self-irony makes itself perceptible in his works. And that is exactly what Kallas, I suppose, was not prompted to do in her aesthetics. ${ }^{13}$ Her artistic aim, which conducted her also towards a form of expression with clear religious insinuations, was a representation of love as a force which pierces the diverse layers of being and which, accordingly, must be claimed free of biological, ideological or whatever determinacy; in other words, she aimed at a representation of love as freedom of anima. The existential "nihilism" as source of personal freedom is exemplified by Kallas not in its atheistic but religious ramifications. Of course, it can be objected that it was rather the unhappiness of the life of the women, and even more Kallas' use of an archaic style of chronicle that induced the respective characteristics of the stories. But I think this is not the case, at least not the full one. She searched in her works for an answer to problem of how to pose the question of woman's consciousness in terms of its extension from biological body to other forms of reality, with an intimated aim, on the part of woman, to be perceived as a linkage in the existential chain of being.

We have insisted that there exists a noumenal emptiness in the centre of the prose ballads, meaning that we have given practically no information about the women's love. What should be placed there? Is it eroticism, revealed by Tuglas, but replaced with thanatic effects by Kallas? I would say that this kind of answer is not necessarily wrong. Kallas tends to keep the intimate side of her women in silence. But I add that it would be extremely misleading not to notice the arch connecting the possible erotic involvement of Kallas' women to their aspiration of overcoming the determinacy of their personal being and consciousness. If eroticism is something to be equalled with the noumenal "thing in itself" in the artistic system of her prose ballads, it is also something to be described only by the stretch to the other side of consciousness.

\section{Conclusion}

Probably it is hard to deny that Kallas' works in general are characterized by a certain flavour of archaism, manifesting itself even more obviously in the prose ballads supposed to be her artistic zenith. Leaving aside the formal characters she uses to echo the effect (or correctly said, to lend the historical subtext a proper expression), Kallas' women have been depicted not so much in action as suggesting and inspiring certain feelings and thoughts 
in men. This attitude has been, by the way, typified by Kallas at times as a proper role of woman, expressing in a more general way Kallas' reservations about the too-bold fronting of gender roles by feminism. ${ }^{14}$ As regards to the motif of casting her look towards the God at the brink of supposed erotic love, the idea has been impressively testified to on the pages of Kallas' diaries. I would like to call this reticence in breaking the rules a perceived demand on the part of Kallas to retain a certain archetypal structure to the world. The notion of creating or making out of nothing, achieved by Christianity to formulate its conception of God, has proved itself to be a sharp weapon in demolishing the so-called essentialist views and in grounding everybody's freedom of action as a true source of meaning. But I think bringing the whole issue onto an entirely human level, together with a nullification of the question about faith, entails a danger - for the reason that the religiosity of being, as the complementary counterpart of the psychic or intellectual level of being, is demanded by the human mind to do its proper work. The cooperation of entities and notions between different levels of mind is surely an appreciated source of mutual inspiration, but the establishment of meaning, for example, on the level of intellect should not cancel its existence as a delusion on some other level - because it would cause the human mind to cease functioning properly. The deconstructing of essences under the banner of priority of existence implies, inasmuch as it excludes transcendence, an impasse because it can only lead to the celebration of some other elevated essence. In my reading of Kallas, the certain archaism featured in the prose ballads is a mark of her wish to make an offering, in her art, to the integrity of being. Love purified of essences and of archetypicality (including that of a man and of woman) has nothing to be in love with and, accordingly, that kind of existence can be a mark of perfection in the case of the God, but is a mark of poverty in the case of a human. In a like manner, the world reduced to human existence alone provides no place for love to grow - and that is what Kallas has surely not targeted.

\section{Notes}

1. The article has been prepared within the framework of the targeted financing project "Autogenesis and Transfer: The Development of Modern Culture in Estonia".

2. By its content and scope, the term "prose ballad" possesses in the case of Kallas a wider and not very definite meaning. Kallas used to call all her works from the twenties prose ballads, giving no explicit definition of the term (see Laitinen 1995, 104-108).

3. A good classification of his system of philosophy has been given by Kant in his "Einteilung" to the Kritik der Urteilskraft (Kant 1963, 21-61). For further reading on the influence of Kant on modern existentialism, see e.g., Solomon 1972, 7-38. The connections between Kant's Existenzphilosophie and early Romanticism have been thoroughly studied by Manfred Frank (see e.g. Frank 1997, 667-682; Frank 2007; Feger 2007).

4. For a general overview of the history of existentia see Hadot-Guggenberger 1972. It should be noted that although the new meaning of being (as existentia) asserted 
itself in the $4^{\text {th }}$ century AD in the works of Marius Victorinus, who applied to the designation of it also the respective Latin word, the meaning of the word existentia remained inconsistent and variable in the Middle Ages (according to Gilson it stabilized only in the $16^{\text {th }}$ century; see Gilson 1987,355$)$. Thus by using the word existentia here and afterwards in my text, I refer in a loose manner to the new mental concept that had been formed in the Christian debates, not to the word established as a designation of that concept in the Latin world.

5. As to how the God's free will had acted on the modern concept of possibility, see Deku 1956.

6. The Sartrean low estimation of love as of a wish to possess the freedom of other person and, on the other hand, as of a perpetual danger to become somebody's object (i.e. to lose the nothingness - the being-for-itself - as a basis of one's consciousness) is well-known (see Sartre 1992, 474-493; Solomon 1972, 311-313; cf. with very different positions of Kierkegaard, Jaspers or Marcel.) In his history of the concept of love, Helmut Kuhn has described the atomization of the elements of love, introduced by Nietzsche, as a vacuum "where the counter-forces assume a dangerous freedom not entitled to them" (Kuhn 1975, 248; see also Gadamer's review of the study, Gadamer 1987a). Reviewing Kuhn's other book, has Hans-Georg Gadamer pointedly delineated the two different attitudes entailed in the existentialist nothingness: while the proper Existenzialismus gains from the ontological negation in a spontaneous self-project a total self-affirmation (während aber der Existenzialismus ... aus der ontologischen Negation in spontanem Selbstentwurf eine totale Selbstaffirmation gewinne), the other (Kuhnian) way to take it is as a means of becoming aware of the reality which embraces and holds the self and all the being (Innewerden einer Wirklichkeit, die das Selbst und alles Sein umfasse und trage) (Gadamer 1987b, 230) - with clear implications for love and conscience (Gadamer 1987b, 232).

7. Without wishing to enter more deeply into the subject here, I refer only to the appendices included in the second edition of Étienne Gilson's book L'Être et l'essence where he comments from the position under discussion the existentialist views (including the replacement of human for the God) in the philosophies of Sartre and Heidegger (Gilson 1987, 357-378).

8. [...hänen harmaat silmänsä loistivat niinkuin virran kalvo, enkä minä ole häntä ennen niin riemullisena ja nauravaisena nähnyt. Eikä hänen kujeillansa ollut mitään rajaa, ja niin he ilakoivat sen Herra Diaconuksen kanssa niinkuin kaksi vallatonta lasta, ja Catharina Wycken sallei Herra Diaconuksen opettaa itsellensä uusimpia viisuja, joita he sitten yhdessä lauleskelivat, sillä Catharina Wyckenillä oli heliä laulunääni. Vaan minun mielessäni alkoi viritä niinkuin hienoista levottomuutta, niinkuin viinamarjan mahlassa, koska se astioihin kootaan ja kannen alle seisomaan pannaan.] (Kallas 1926, 111-112.)

9. [Niin hän vastasi, taas nousten, eikä itkenyt enää: "En minä eroa Franz Bonniuksesta, vaikka minun pitäisi nälkäkuolemalla kuoleman hänen takiansa." Ja silloin minä hänen silmistänsä näin, että se hänen totinen ja vakaa tahtonsa oli, ja että hän oli valmis antamaan henkensä tämän miehen edestä ja hänen kanssaan.] (Kallas 1923, 51.)

10. [Nagu luik ujusin ta silmade läikival pinnal ...] (Tuglas 1917, 35.)

11. [Niin hän alkoi suuresti halajoida uudellensa saman suden nähdäksensä, joka Kassarin saarella oli hänen luodiltansa pakoon päässyt... Niin ei hänelle mikään enää mitään merkinnyt, ei menestys eikä maallinen onni, vaan öin ja päivin hän nyt vain tätä yhtä metsänsutta ajatteli, jonka hahmossa hänen vaimonsa Aalon sielu yhä harhasi, lumostansa pääsemättä... Ja hän oli öisin unissansa usiasti näkevinänsä samaisen suden, joka seisoi hänen polullansa, koska hän metsiä vaelti, ja häneen sangen haikiasti tuijotti, niinkuin olisi vangittu sielu vapahdustansa vartonut. Niin vihdoin viimein hän ei jaksanut tätä sielunsa hätää kestää, vaan se 
hänelle yli voimain kävi, niinkuin ylön raskas kantamus. Vaan yhtenä huomenena hän etsei esille sen hopiaisen vihkisormuksen, jonka Pühalepan pappi kerran kirkon alttarin edessä oli hänen sormeensa sovittanut, yhdeksi merkiksi P. Aviosäädystä.] (Kallas 1928, 133-134.)

12. [Mutta koska minä katselin tätä kuolevata joutsen-lintua, niin minä kauhistuin hengessäni, ja pääni hiukset nousivat pystyyn, niinkuin henki olisi ohitseni kulkenut. Sillä joutsenen silmistä, jonka kuoleman piti, katselivat minua vaimoni Catharinan silmät, niinkuin ne olivat hänen neitseellisessä nuoruudessansa, arat ja untanäkeväiset, ja niinkuin armoa anoen... Näin minä vaikersin ja ääneen huutelin:"Voi sinuas, Catharina Wycken, - miksis menit, miksis minun hyljäsit! Katso, he rupesivat sinun valkiaan kaulaasi, ja sen miekallansa katkaisivat." Ja nyt minä vasta selkiästi tiesin, etten minä milloinkaan ollut herjennyt tätä vaimoa rakastamasta.] (Kallas 1926, 238-239.)

13. For example, in the first volume of her diaries (1897-1906), God has been assigned a definite place in Kallas' discourse on personal love experiences. In a description (from 27.05.1900) from time of her engagement with her future husband Oskar Kallas, she writes: "A week ago! How to represent that day, or could I represent it at all! ... This Sunday nine months had passed from the day he handed me the letter in Kuorsalo. Nine months needs a child for growing before birth, nine months needed our love to become adult. It erupted that night, in words, feelings, thoughts, wholly and readily. It was our second engagement night. I was all the time conscious of the presence of God and of the fact that that He saw us. People could condemn us, I know, but God? Yes, maybe the force in us needs restraining and keeping in check, but it cannot be bad in itself." [Viikko sitten! Millä lailla sitä päivää kuvaisin tahi voinko sitä lainkaan kuvata! ...Sinä sunnuntaina oli yhdeksän kuukautta kulunut umpeen siitä kesäillasta, jolloin hän oli antanut minulle kirjeen Kuorsalossa. Yhdeksän kuukautta tarvitsee lapsi kasvaakseen ennen syntymää, ja yhdeksän kuukautta oli rakkautemme tarvinnut täysikasvuiseksi tullakseen. Ja se tulvahti esiin sinä yönä, sanoina, tunteina, ajatuksina, eheänä ja valmiina. Se oli meidän toinen kihlausiltamme. Minulla oli koko ajan tieto Jumalan läsnäolosta ja siitä, että Hän näki meidät. Ihmiset olisivat meitä tuominneet, sen tiedän, mutta entä Jumala? Niin, kenties se voima meissä tarvitsee hillitsemistä ja aisoja, mutta se ei voi olla paha itsessään.] (Kallas 1952, 219-220.) Is it a God looming up only perforce of the respective discourse of the age - something to be really discarded when the matters have been settled in our consciousness? My opinion is that it is not the case. This God continues to play a cognitive role in Kallas' later art.

14. Of course, the sentiment dating from late Kallas ("I accepted, as I do it still today, the incontestable intellectual and creative superiority of man. Why then should I have taken a position of fighting?" [Tunnustin, kuten teen yhä tänäkin päivänä, miehen ehdottoman älyllisen ja luovan etevämmyyden. Miksi olisinkaan siis asettunut taisteluasenteeseen?] (Kallas 1946, 50) must not be overestimated, nor pushed into the service of proving some personal preference, but probably it is also not entirely casual. She comes close to the same position, for example, in her survey of Johannes Aavik's vision of future woman ("Ruth" 1909) where she, being quite critical of Aavik, charts also a bit of her own fancies about future woman: "She maybe discards the ambitious dream of modern woman to be in her creative talent equal to man ... Her highest ambition is also to create, but to do it through man. It may be that, aspiring as a woman, she cannot even ascend higher as to release the creative forces in man. The vocation of future woman is then to be a friend of creative man, of genius, to be a source of innovation whence stream humanity's immortal visions of beauty" [Hän on ehkä luopuva nykyajan naisen kunnianhimoisesta unelmasta olla luovana kykynä miehen veroinen... Hänenkin korkein kunnianhimonsa on oleva luoda, mutta luoda miehen kautta. Voi olla, 
ettei nainen, naisena pysyessään, koskaan voikkaan korkeammalle kohota, kuin juuri vapauttaessaan miehessä luovan voiman. Tulevaisuuden naisen kutsumus on silloin olla luovan miehen, neron, ystävätär, uudistuksen lähde, josta ihmiskunnan kuolemattomat kauneusnäyt kumpuavat.] (Kallas 1918, 214-215). In her diary Kallas has said (in an entry from 17.10.1912) that becoming a writer might be viewed as a compensation for the fact that she had not been offered an opportunity to prove herself as la grande amoreuse (for which, as she says, she was born - "to love Michelangelo, Dante, Gallén, Rodin, to them could I have sacrificed my creative talent" [Olin luotu suureksi rakastajattareksi - "la grande amoureuse", rakastamaan miestä sellaista kuin Michel-Angelo, Dante, Gallén, Rodin, hänelle olisin voinut uhrata luovan kykyni] (Kallas 1953, 278). (See also Kurvet-Käosaar 2006b). Indeed, it has been noted that "the beginning of the full realization of her creative talent also marks a near complete disappearance [in her diary] of the themes related to the body and sexuality" (Kurvet-Käosaar 2006a, 70). The relationship between creativity and the role of wife, emerging so importantly in Kallas' diary, has recently been carefully studied in the context of feminism of the respective period (Kurvet-Käosaar 2006a). I would additionally wish to insist only on Kallas' stance to leave untouched, in tackling the problem of woman's consciousness, certain things which I term, for lack of better name, an archetypicality of the world.

\section{References}

\section{Research objects}

Kallas, Aino 1918: Nuori-Viro. Muotokuvia ja suuntaviivoja. [Young Estonia. Portraits and Trajectories.] Helsinki: Otava.

Kallas, Aino 1923: Barbara von Tisenhusen: Liivinmaalainen tarina. [Barbara von Tisenhusen: A Livonian Tale.] Helsinki: Otava.

Kallas, Aino 1926: Reigin Pappi: Hiidenmaalainen tarina. [The Rector of Reigi. A Tale from Hiiumaa.] Helsinki: Otava.

Kallas, Aino 1928: Sudemorsian: Hiidenmaalainen tarina. [The Wolf's Bride. A Tale from Hiiumaa.] Helsinki: Otava.

Kallas, Aino 1946: Uusia kanssavaeltija ja ohikulkijoita. Muistoja ja muotokuvia. [New Fellow Travellers and By-passers. Memories and Portraits.] Helsinki: Otava.

Kallas, Aino 1952: Päivakirja vuosilta 1897-1906. [Diary from the Years 1897-1906.] Helsinki: Otava.

Kallas, Aino 1953: Päivakirja vuosilta 1907-1915. [Diary from the Years 1907-1915.] Helsinki: Otava.

Kallas, Aino 1975: Three Novels. Trans. Alex Matson. Helsinki: Otava.

\section{Research literature}

Damisch, Hubert 1994: The Origin of Perspective. Trans. John Goodman. Cambridge (Mass.): The MIT Press.

Deku, Henri 1956: Possibile logicum. Philosophisches Jahrbuch des Gorres-Gesellschaft 64. 
Feger, Hans 2007: Poetische Vernuft. Moral und Ästhetik im Deutschen Idealismus. Stuttgart, Weimar: J. B. Metzler.

Field, Judith Veronica 1997: The Invention of Infinity. Mathematics and Art in the Renaissance. Oxford: Oxford University Press.

Frank, Manfred 1991: Fragmente einer Geschichte der Selbsbewußtseins-Theorie von Kant bis Sartre. In: Manfred Frank (ed.), Selbsbewußtseinstheorien von Fichte bis Sartre. Frankfurt am Main: Suhrkamp.

Frank, Manfred 1997: "Unendliche Annäherung". Die Anfänge der philosophischen Frühromantik. Frankfurt am Main: Suhrkamp.

Frank, Manfred 2007: Existenz, Identität und Urteil. Schellings späte Rückkehr zu Kant. In: Manfred Frank, Auswege aus dem Deutschen Idealismus. Frankfurt am Main: Suhrkamp.

Gadamer, Hans-Georg 1987: Liebe, Geschichte eines Begriffs (H. Kuhn). In: Hans-Georg Gadamer, Gesammelte Werke. Band 4. Tübingen: J. C. B. Mohr. (1987a)

Gadamer, Hans-Georg 1987: Begegnug mit dem Sein (H. Kuhn). In: Hans-Georg Gadamer, Gesammelte Werke. Band 4. Tübingen: J. C. B. Mohr. (1987b)

Gay, Peter 1996: The Enlightenment: An Interpretation. The Science of Freedom. New York - London: W. W. Norton \& Company.

Gilson, Étienne 1987: L'Être et l'essence. Deuxième edition. Paris: J. Vrin.

Grant, Edward 1999: Much Ado About Nothing. Theories of Space and Vacuum from the Middle Ages to the Scientific Revolution. Cambridge: Cambridge University Press.

Hadot, Pierre-Guggenberger, Alois 1972: Existenz; existentia. In: Joachim Ritter, Karlfried Gründer, Gottfried Gabriel (eds.), Historisches Wörterbuch der Philosophie. Band 2. Basel: Schwabe Verlag.

Kant, Immanuel 1977: Der einzig mögliche Beweisgrund zu einer Demonstration des Daseyns Gottes. In: Wilhelm von Weischedel (ed.), Immanuel Kant, Werke in zwölf Bänden. Band 2. Frankfurt am Main: Suhrkamp.

Kant, Immanuel 1963: Kritik der Urteilskraft. Stuttgart: Philipp Reclam jun.

Koyré, Alexandre 1965: Newton and Descartes. In: Alexander Koyré, Newtonian Studies. Cambridge (Mass.): Harvard University Press.

Kuhn, Helmut 1975: "Liebe". Geschichte eines Begriffs. München: Kösel.

Kurvet-Käosaar, Leena 2006: Embodied Subjectivity in the Diaries of Virginia Woolf, Aino Kallas, Anaïs Nin. Dissertationes Litterarum et Contemplationis Comparativae Universitatis Tartuensis 6. Tartu: Tartu University Press. (2006a)

Kurvet-Käosaar, Leena 2006: Aino Kallase haakumisi J. Randvere "Ruthiga" moodsa naise kuju pinnalt. [The Notion of the Modern Woman in the Work of Aino Kallas and J. Randvere's "Ruth".] In: Mirjam Hinrikus (Ed.), J. Randvere Ruth 19.-20. sajandi vahetuse kultuuris. [J. Randvere's "Ruth" in the Context of the Turn of the 19th Century.] Tallinn: Underi ja Tuglase Kirjanduskeskus. (2006b)

Laitinen, Kai 1995: Aino Kallaksen mestarivuodet. Tutkimus hänen tuotantonsa päälinjoista ja taustasta 1922-1956. [The Master Years of Aino Kallas. A Study of the Main Topics and Background of her Work 1922-1956.] Helsinki: Otava.

Puhvel, Jaan 1965: Filles du Soleil: Folklore Estonien et Mythologie Indoeuropéene. - In: Viktor Kõressaar ja Aleksis Rannit (eds.), Estonian Poetry and Language: Studies in Honor of Ants Oras. Stockholm: Vaba Eesti.

Sartre, Jean-Paul 1968: L'existentialisme est un humanisme. Paris: Nagel.

Satre, Jean-Paul 1992: Being and Nothingness. A Phenomenological Essay on Ontology. Trans. Hazel E. Barnes. New York, London: Pocket Books.

Solomon, Robert C. 1972: From Rationalism to Existentialism: The Existentialists and Their Nineteenth-Century Backgrounds. New York: Harper \& Row.

Tuglas, Friedebert 1917: Saatus: Novellid. [Destiny: Novellas.] Tallinn: Maa.

Tuglas, Friedebert 1982: At the End of the World. In: F. Tuglas, Riders in the Sky. Trans. Oleg Mutt. Tallinn: Perioodika.

Tuglas, Friedebert 2007: The Poet and the Idiot. In: F. Tuglas, The Poet and the Idiot and 
Other Stories. Trans. Eric Dickens. Budapest: Central European University Press. Undusk, Jaan 2005: The Untranslatability of Body: Remarks on Language in the Extreme. In: Rein Undusk (Ed.), At the End of the World: Text, Motif, Culture. Collegium Litterarum 18. Tallinn: The Under and Tuglas Literature Centre.

Undusk, Rein 2005: Love and language. The Romantic Background of Tuglas' Short Story. In: Rein Undusk (Ed.), At the End of the World: Text, Motif, Culture. Collegium Litterarum 18. Tallinn: The Under and Tuglas Literature Centre.

West, Martin Litchfield 1975: Immortal Helen: An Inaugural Lecture. (Delivered on 30 April 1975). University of London, Bedford College. 
Life on the Borders 



\section{Aino Kallas on the Boundaries of Finland, Estonia and the World}

The nineteenth century was a century of great change in Europe. The beginning of a new century brought changes even to marginal areas far from the centres, such as Russia's western provinces of Estonia and Livonia and the Great Duchy of Finland. The situation in Finland was more favourable than in Estonia; Finland had a unique autonomy within the borders of the Russian Empire and the central government started to set restrictions to it only in the last decade of the nineteenth century. The southern coast of the Baltic Sea, however, had been more firmly tied to the empire and the Baltic-German landowners had already for centuries behaved as masters there. When the area of present-day Estonia was incorporated into Russia in the early $18^{\text {th }}$ century, the central government maintained the socalled Baltic special order in these provinces, which doubly subjected the indigenous population of the land both to the Baltic Knighthood and the Russian central government. The goal of the Estonian national movement in the 1860s and 1870s was to create, in the midst of Russian and German cultural influences, an Estonian culture of its own. Its first fruits ripened after the hard time of Russification in the 1880s, at the end of the nineteenth century, when Estonian literature and Estonian culture in its wider sense, including studies in the Estonian language and history, acquired a firmer basis. Since the beginning of the national movement, its figures had stressed the importance of kinship with the Finns, and searched for and found contacts and models in Finland. It was Helsinki where Estonians went to study the emerging disciplines of Estonian linguistics and folklore that were absent from the curricula of the Russian-language University of Tartu. Jakob Hurt, who had studied theology and launched a campaign of collecting authentic Estonian folklore, defended his thesis in Helsinki and recommended young Oskar Kallas to his colleague and friend Kaarle Krohn, who became Kallas' scholarly supervisor. In the summer of 1899 , Oskar Kallas met Aino Krohn, fell in love and proposed marriage. Ten years his junior, she accepted him and left Finland after the wedding, first for St. Petersburg due to the work of her husband, and later, for Tartu. In such a manner it happened that Aino Kallas, rather unknowingly and due to circumstances, stepped onto several different frontiers that determined the shape of her literary career. 
Aino Kallas was sure of her literary calling when still very young, and now she had to start moulding it on the borders of two cultures: in the Finnish language, but living in Estonia. Marriage to Oskar Kallas introduced her to the circle of authors of the newspaper Postimees, where Oskar Kallas was one of the central figures. This circle, to a certain extent, reminded Aino of the high-principled background of her father or older brother. She found it easier to relate with the next generation of young writers whose aspirations were similar to hers: Gustav Suits, Friedebert Tuglas, Villem Grünthal, and others. The Noor-Eesti [Young Estonia] group, created by these writers, offered Aino Kallas in the first half of her literary career a circle whose creative works she was able to identify with, whose publications mostly (but not only) published her works, and about whom she wrote a long essayist overview book Nuori Viro. Muotokuvia ja suuntaviivoja [Young Estonia. Portraits and Trajectories, 1918]. (See also Laitinen 1995a, 110-131; LeskeläKärki 2006, 141).

In this article, I will examine Aino Kallas as a writer on the borders of two cultures and two generations. In 2008, Estonian Academician Jaan Undusk self-evidently writes in his commentary to the publication of a new edition of Kallas' Reigi ópetaja [The Rector of Reigi], "Aino Kallas is one of those rare Estonian writers whose main works were not born in the Estonian language" ${ }^{\prime}$ (Undusk 2008). Finnish researchers, and even more so, Finnish readers, are more than surprised of such a view of Kallas as an Estonian writer, as they consider Kallas, a daughter of a Finnish patriot, a Finnish writer, a classic of Finnish literature, who nonetheless mainly wrote on Estonian subjects. At the same time, many Estonian researchers have considered Aino Kallas' work, partially or even as a whole, as belonging to Estonian literature.

Aino Kallas entered Estonian literary life on the threshold of great change at the beginning of the $20^{\text {th }}$ century. Estonian literature was still young; its contents were mostly about national patriotic poetry and realist village prose. The generation of Young Estonia heralded new ideals, promising to create artistically valuable intellectual literature. The corresponding change in Finnish literature had occurred slightly earlier and had, surprisingly, headed in a different direction. Modern Finnish writers and artists had by the end of the $19^{\text {th }}$ century discovered realism and were, therefore, facing the east and the past. Young Estonians, many of whom had models and contacts in Finland, turned away from the past -especially from the literature of the past - and loudly voiced their aspiration to be not only Estonians, but also to become Europeans as well.

Aino Kallas, at the time Aino Krohn, had debuted when still very young, and at the beginning, she was uncertain about her creative ambitions. At the time she left Finland, Neo-romanticism was on the rise there; she did not share its ideas, but preferred to write in a realist key. The young Estonian literature of the beginning of the $20^{\text {th }}$ century also stood at a crossroads of methodology and style. Kallas' contemporary prosaists Anton Hansen Tammsaare (born 1878) and Friedebert Tuglas (born 1886) had debuted with realist works in the first years of the $20^{\text {th }}$ century, but had, having been influenced by the Russian revolution of 1905 and Russian literature in gen- 
eral, moved to romantic or modernist trends. In its first period of development, Young Estonia searched for suitable methods and changed quite rapidly; its members were united only by their wish to create modern, contemporary and artistically valuable literature - a term which all of them interpreted in their own ways. Young Estonians rebelled against the previous generation, against the same Postimees circle, which, due to Oskar Kallas' contacts, included Aino Kallas as well. In her diary we can find many enthusiastic referrals to Jaan Tõnisson and remarks about how long talks with Tõnisson had helped her to adapt to the world and to life and to gain a better understanding of herself. Jaan Tõnisson (1868-1942?) was a close friend of Oscar's, a national politician and, at the turn of the $20^{\text {th }}$ century, the leader of the circle who carried out the so-called Tartu Renaissance. ${ }^{2}$ Although Tõnisson had at the beginning supported the younger generation, specifically the later leader of Young Estonians, Gustav Suits (1883-1956), tensions grew between the two generations, especially after the year 1905, which later led to several confrontations. Throughout her Tartu period, Aino Kallas literally moved on the margins of two different understandings of life and art, having to balance between the Postimees-circle and Young Estonians.

Kallas' position in the women's movement of the early $20^{\text {th }}$ century, which she regarded with scepticism, was similarly on the margin. The Estonian women's movement came to life before and during the year 1905, and had very radical objectives. Several of the first Estonian outstanding women's activists lived in Tartu at that time and chose political activities, joining the social democratic party (Alma Ostra-Oinas, Minni Kurs-Olesk, Alma Ast, Linda Jürmann-Vilde and others). Aino Kallas did not belong among them but rather, she had chosen the opposing side. During these years, Estonian society rapidly differentiated into the bourgeoisie and "the others" (who can be called revolutionaries, radicals or still something else), and Aino Kallas belonged, due to her husband's and her own convictions, among the bourgeoisie. At the same time, thanks to her outlandish origin, she had wider world experience and was, especially because of her writing, an untraditional woman in the Tartu of the time. In Finland, Aino Kallas had been accustomed to a more liberal and open attitude towards the role of women. At the time when she started her literary activities as a Finnish writer, there were several other female authors from whom she did not differ much. In Estonian families, the old Baltic Kirche-Küche-Kinder-model ${ }^{3}$, unfamiliar in Finland, was still dominating. For Oskar Kallas, such a model would have been quite natural, but knowing circumstances in Finland, he realised that Aino Krohn could not be subjected to such treatment. Aino had been very young when they married, inexperienced in practical matters, and the habits of their family were shaped according to Oscar's ideas. Respect for his wife's spiritual aspirations occupied a central role in these ideas. When they married, Oskar was well aware of his wife's wish to write and he supported her in every way, although this support was based on love rather than deep convictions. Estonian female writers had existed, but their number had always been very small. Aino Kallas, the only woman in the core of Young Estonia and one of the few women in Estonian literature and journalism of the time, was an exception as well. 
Even here, her personality and through it, also her work, were on the edge; antagonism between being a proper housewife and a creative woman tortured her soul and yet enhanced her work. Continuous balancing within national and conventional confines might have tried her nerves, but it also widened her outlook. A question about where she belonged and what kind of people formed her circle also hints at the question about the limits of her personality and/or creative work and asks where her roots are. One's roots are in one's origins, in one's family. For Kallas, her father's side was an international clan of the Krohns, alien blood that moved from country to country carrying the blood heritage of forefathers of several different nationalities, a clan at home everywhere and nowhere in particular. There was a period in Aino Kallas' life, at the turn of the first decade of the $20^{\text {th }}$ century, when she actively searched for her relations and listened to the memories of her forebears. Doing this, Aino Kallas felt to be a true and genuine member of the large Krohn family - not only a Finn by blood, although she had had very patriotic upbringing, but also possessing of a character that was one of the creative, free and passionate women of the clan - the true women of the Krohns.

Yuri Lotman describes boundary in the semiotic sense as the most important functional and structural position that determines the object's internal meaning, and its possibilities. A boundary acts as a catalyst; processes are always swifter on the boundaries, meaning in the marginal areas, and the new is always born on the boundary (Lotman, 1992). The boundary between Estonianness and Finnishness in Aino Kallas' work is changing and often ambivalent. In fact, in 1900, when an Estonian Oskar Kallas married a Finn Aino Krohn, it was not a marriage across borders of the states; they lived in one and the same Russian Empire and even their first home together was, due to circumstances, set up in the centre of this state, its capital St. Petersburg. At home, they at random used the Estonian, Finnish and German languages, which they both knew. For Aino Kallas, this centre was not a centre in a spiritual sense; she did not feel at home in this metropolis, she kept to the walls of her own home, she was not interested in Russian culture, and when she socialised outside her home, it was then only with Oskar's relatives and acquaintances, Estonians or Balts. Regarding her spiritual development, St. Petersburg was like a no man's land, a kind of interlude, the time and space when and where she grew apart from Finland and prepared to settle down in Estonia. In St. Petersburg, Kallas completed her first novel Kirsti (1902), her only work where the protagonist was a modern Finnish woman with her psychological problems. This in several senses was an unsuccessful novel, and it was her last attempt to find subjects for her work in contemporary Finnish life.

Aino Kallas had married a member of a kindred people, not a stranger: both Julius Krohn and Oskar Kallas were patriots for whom the kinship between the Estonians and Finns was important. Young Aino Krohn had grown up in the spirit of Finnish patriotism. Her diary entries of February 1899, when the Russian state applied restrictions to the Finnish autonomy with the so-called February Manifesto, are worth mentioning. Aino was in Lausanne, away from Finland, and expressed her feelings: "I have no father- 
land any more! This is a sorrow, a large, bottomless, hopeless sorrow... My country, my people, my dear people!"4 (Kallas 1952, 149).

These words are, without doubt, subjectively sincere. However, we can recall how Aino later admitted to Oskar that they, the Krohns, were "taught patriots", a kind of theoretical patriot, whose roots were not very deep. "The way it affects artistic development is also clear - there is no sense of identity with the people one is writing for, the firm basis and background are missing." (Aino Kallas to Oskar Kallas on 06.03.1902. KM EKLA f 186, m 57:61). Such "theoretical Finnishness" was inevitable; Aino's father was dead, and although his meaning was still great for Aino, it was still only an ideal without real content. Aino had left Finland when still young and she had several times admitted that her knowledge of the country and its people was not deep. Therefore, she prepared herself during her engagement period to become "an Estonian woman, a wife of an Estonian man and one of Estonian daughters"s (Kallas 1952, 205). Balancing between Finland and Estonia, she found a source for literary inspiration on the Island of Saaremaa - even many years later she repeatedly says that she feels at home and happy at that place. The past of Saaremaa, revealed to her through local oral tradition, inspired her fantasy. The nature of Saaremaa affected her sense of beauty, and a love for Oskar helped to create trust for Oskar's home as well. Saaremaa and Tartu are the Estonian places, where she first adapted to Estonia and which helped her to understand Estonia. The issue of literary themes is solved in such ways that in her further work, Estonian subject matter usually prevails, mostly drawn from Estonian history. On 19 February 1906, after having published a collection of short stories Meren takaa [Beyond the Sea], she wrote from Tartu to Ilona Jalava:

I was brought up to become a fanatic, at least regarding national issues, but now, I have gradually become absolutely tolerant, although I do not pay duties to cosmopolitanism. This is not inconsideration, this is a result of the fact that I have, against my own will, been torn out from my familiar environment and been forced to become an bystander; I cannot become accustomed to strange circumstances to such an extent that I lost my critical eye. There is a word that I have become more and more attracted to - "humaneness" - it appears before me as a distant ideal; this understanding, loving high humaneness regards a human being as the supreme. (Kallas 1988, 269.) ${ }^{6}$

Aino Kallas wanted to write and had to find the subjects to write about. In her earliest works she often depicted people from her near vicinity, and her own life - feelings and thoughts that were important for her. The period of such mimetic copying inevitably had to come to its end with the growing load of experience, as narrow personal subjects started to limit her creative work. She was away from Finland and did not know Finnish life well, thus she had to find her subjects elsewhere. The nature of Saaremaa and the stories about the days of serfdom on the island, told by old Carl Allas in the summer of 1903, were a real gift for her. These stories launched her fantasy and shocked her sense of justice. Looking forward, we can see that after the publication of her collection of short stories Meren takaa, Kallas again 
tested several different possibilities by writing a novel about her contemporary Estonian life (Ants Raudjalg, 1907), a verse drama on a biblical subject (Bathseba, 1909) and a biography of an Estonian literary classic (Tähdenlento, [The Shooting Star], 1915). The first of these was called a failure by Estonian literary critic Gustav Suits, who shared her ideas, the second attempt was rejected by Finnish critic Jalmari Hahl, and she herself thought that the third one was a "work of the second rate"(Kallas 1952, 346-347)7, because for her, only a work of fiction was a work of the first rate. At about that time she found, almost half-accidentally, a subject of truly inspiring nature, a true story of Estonian sectarians, the followers of Prophet Maltsvet, which she shapes into a mythical and suggestive short story "Lasnamäe valge laev" [The White Ship] in the collection Lahkuvate laevade linn [The City of Departing Ships] (1913).

Finland was the country of Aino Kallas' birth, and in Finland she started her literary career; only a few days before she first met Oskar Kallas she had written in her diary: "In autumn, the circle of writers will be open for me and I know that I shall feel at home with them"8 (Kallas 1952: 189). Aino Kallas - a daughter of Julius Krohn and the sister of Helmi Setälä - was accepted in literary circles already for her family ties; such acceptance was probably so natural that she does not elaborate about it in her diary and only seldom mentions some meetings and practical issues related to publishing.

Kallas wrote Kirsti still in the key of the Finnish literary canon, though at that time she certainly did not think about any canon, but rather, about the things and ideas that were in fashion, as she customarily derived her subject from her own feelings in her younger years. How did she conceive the writer's task at that time? Probably she thought that a writer had to discuss subjects that were topical, sensitive or painful; the text had to be accurate, honest and interesting. Characteristically, she was unsure in the value and reception of her Kirsti, but at the same time, she was fully convinced that she had had to write just such a text in just such a way and also had to publish it. She had the necessary moral courage for discussing a subject that was obviously disagreeable for her mother and older brother - premarital sexual relations. At the same time, she did not listen to suggestions that she should change or drop the subject,

... but if someone has put all her power that she had on that particular stage of development into a work of hers, then the audience has the task of helping her to rise above this stage of development by reading and criticising her book. Nothing could help or advance a writer more than the opportunity of being publicly criticised. I necessarily need this book as a staircase, where I can step to the new level in both the artistic or thematic sense. If this book were left in a drawer of my desk, my development would be interrupted for a long time. (Kallas 1952, 282.) ${ }^{9}$

Aino Kallas' relations with Finnish literary circles are reflected in some other ways as well, most directly in a magazine called Valvoja that often published her writings, mostly about Estonian literature. As Gustav Suits and Johannes Aavik, who both studied in Helsinki, very rarely managed to publish in this magazine, and Friedebert Tuglas, who lived in Helsinki, could not publish 
there at all, it fell just to Aino Kallas to introduce young and ambitious Estonian literature to the Finnish public.

While we could argue that Aino Kallas' national identity was insecure, we have to admit that her artist's calling has from the very beginning been, as she expressed later in her life, "intrinsic, the deepest and firm as a rock"10 (Kallas 1957, 127). Her search for her own way and her own style in literature is well reflected in her diaries. When her first child was born, she wrote in her diary about "a battle between mother's love and my artist's talent" ${ }_{11}$ (Kallas 1952, 272). Aino Kallas does not behave like a bluestocking: she loves her children and spends time with them, at the same time still regretting that she has to do it at the cost of her writing. This is not too tragic; this is simply her life, where she finds unexpected and enriching solutions when balancing between these choices. She is away from the habitual Finnish cultural life, but on Saaremaa she finds numerous enchanting and exciting literary themes. She could yearn for glamour and festiveness, but she can enjoy the joys of family life as well. When still in St. Petersburg, she wrote in her diary that she had given up the idea of permanent residence in Helsinki: "This would be no good, bringing up children and problems arising from our different nationalities would be too difficult to cope with"12 (Kallas 1952, 289).

Problems of being a writer, questions about how and about what to write formed the core of her spiritual life in Tartu and lessened her homesickness. The Helsinki literary circles were far away, but were replaced by talks at the editorial office of the Postimees and the Young Estonia literary evenings. Aino Kallas was one of the first critics in Estonia, let alone in Finland, who followed the renewing of Estonian literature, describing and analysing its developments (see Olesk 2003). Kallas could most efficiently overcome her natural homesickness just by reading and writing; the need to be a writer was more important for her than the question of whether she was living in the Finnish or Estonian cultural context. Actually, she was living in both of them - her publisher was in Finland and her books were read and criticised in Finland. But she took a more active part in Estonian literary life and communicated with Estonian writers, was a member of literary juries, and published articles and reviews in Estonian magazines. Her works of fiction were translated soon after their publication and critics discussed them as a natural part of Estonian literature. Such practices allowed her to draw from both cultures. Occupying such a position, she could find ideas that enriched her artistic work - such as abandoning Estonian realism and searching for new directions - as well as her essays and criticism.

In the spring of 1913, the first truly approving criticism of Kallas' work - a collection of short stories Lähtevien laivojen kaupunki [The City of Departing Ships] - were published in Finland. Reading these reviews, she felt for the first time that she had been understood:

Electricity was coursing through me, but I relaxed soon. Why had it not been said already earlier, eight-nine years ago, when I was so much looking forward to it and secretly felt that I had earned it? ... Nobody had ever mentioned my name before and now, suddenly, it was said that my book had been expected with 'great 
hope'... I have no themes, this is the deepest reason; my soul has not yet swung to the very bottom, which I could write about. I do not want to write about external themes, but do I have any intrinsic experience? Is there any experience besides some continuous, all-killing theorising? (Kallas 1953, 290.) ${ }^{13}$

Kallas found her Estonian themes on Saaremaa in 1903. In her letter to Gustav Suits in 1908 she had promised "to discuss universal problems and Estonian people"14 (Kallas 1953, 63). This had helped her in her quest, but had still not yielded satisfactory results because, as the diary testifies, there had been no soul-shattering experience that could have formed a basis for that. Characteristically for her era, Kallas believed that the intrinsic and deeply touching art could be born only based on personal experience, which can be shaped into a creative work through multiple encryptings just as if it were set to a stage into the shadows of different historical backgrounds. Kallas searched not in literature and history for the themes she wanted to write about, but from real life. She read Lydia Koidula's works and about Koidula, and wrote her biography Tähdenlento [The Shooting Star] (1915), a book where Kallas' self-reflection is interwoven with her study of Estonian culture. During the complicated years of her personal life, Kallas carried with her a manuscript of the so-called "Estonian essays", which later informed the book Nuori-Viro. Muotokuvia ja suuntaviivoja [Young Estonia. Portraits and Trajectories] (1918). The writing of this book required some study of Estonia's near past, and the treatment of her own place and role in this period. In such an atmosphere, she was shaping the short story "Vieras veri" [Alien Blood] and the novel Katinka Rabe in her mind. These connections are not arbitrary at all, because a thorough study of Estonian cultural history gave her the bystander's “eye of a stranger" that allowed her not only to examine thoroughly the contents of her theme, but also to let her treat it in a more general, and here, even mythical way. In the same period, in 1919, Kallas published a translation of Friedebert Tuglas' collection of short stories Kohtalo [Fate], which is carried by the same passion for creating myths. These short stories of Tuglas' lack concrete time or place; the characters are men and women without name and nationality, a monkey and a dog, a Giant Maiden on a faraway island at the end of the World. These stories, too, discuss "universal problems" separated from a concrete country or people.

In Tartu and in the Tartu society, which Kallas sometimes wrote about in her diary with warmth and sometimes with boredom, she moved between the Postimees and Young Estonia. Jaan Tõnisson's name is often repeated in Kallas' diaries. She was deeply interested in and influenced by Tõnisson. She had long talks with him about Tõnisson's or her own personal matters, she argued with him about idealistic or religious problems and later, she already felt that she had to defend the Young Estonia writers against Tõnisson's resentment or scorn, because Tõnisson was an infallible and charismatic popular leader who believed that he was right and unmercifully destroyed those who erred. Who was Jaan Tõnisson? In Estonian politics, he later acquired almost the role of a martyr, because he represented the so-called idealist and high-principled wing against Konstantin Päts, who 
was a newspaper editor in Tallinn and cultivated pragmatic and rational politics. The first constitution of the newly independent Estonia was too parliamentary and governments were changing quite often. Both Tõnisson and Päts were members of many of these governments and also Prime Ministers up to 1934, when Konstantin Päts organised a coup, prohibited political parties, and seized power. In 1935, the Postimees was taken away from Tõnisson; Oskar Kallas had been forced to retire from London a year earlier. But for Aino Kallas, Tõnisson was most influential in her first Tartu years, when his national idealism and authority were most obvious. Being a true leader of people, Tõnisson had also supported young people, the most remarkable among whom had been Gustav Suits. On the recommendation of the Kallas family, gymnasium student Suits had in summers worked as a tutor in Finland, forming necessary contacts and acquaintances, and entered the University of Helsinki at the beginning of 1905. Suits translated into Estonian Kallas' short stories from the collection Meren takaa [Beyond the Sea] and wrote a nice review of them in a magazine Linda, publishing also a photo of Aino Kallas - the first photo of her to appear in the Estonian press. It can be seen from Suits' letters of that time how proud he was of that acquaintance and he asked Aino Kallas to translate his essay on Juhani Aho into Finnish. He also talked about literary news from Helsinki in his letters (Andresen 1996, 139-163). In the end of 1905, Suits published his first collection of poems Elu tuli [The Fire of Life] with a Finnish publisher; Eino Leino wrote an approving review about it in the newspaper Helsinkin Sanomat. This collection became extraordinarily popular in Estonia and Suits became the leader of the new generation and Young Estonians. Aino Kallas wrote propitious articles about it in both the Postimees and Finnish newspapers, but naturally, she had to sense the growth of opposition between the two generations in the revolutionary "red years". The younger generation started to appreciate individualism, socialism and atheism. In 1906, Suits published a collection of essays Sihid ja vaated [Objectives and Perspectives], where an essay "Kaks ilmavaadet" [Two World Views] occupied a central position, describing and motivating the antagonism between Young Estonians and Tõnisson's generation.

In 1907, Suits published a long review of Aino Kallas' novel Ants Raudjalg. This was one of the first reviews where Suits seriously and thoroughly examined some work of fiction; the long review extended through five newspaper issues. Suits praised Kallas' trueness to form, her rich and exact language and elaborateness of descriptions. He approved of Kallas' observant writer's eye in seeing Estonian life, but concluded in the end that Kallas as a Finn still remained a stranger to Estonian life because she did not know its foundations and depths and therefore, could not conclusively understand all of its outward appearances. He carefully and diplomatically phrased his evaluation of the book, writing, "although we have been able to point out a number of relative successes in Ants Raudjalg, it is still clear from the above that we are not dealing with an absolute masterpiece"15 (Suits 1907).

From Aino Kallas' diary we know about her letter to Gustav Suits in answer to the review, where she admits having a creative crisis and analyses her opportunities between the two countries. Suits' answer on January $29^{\text {th }}$, 
1908 to this letter is less known. In our context, it is interesting to note that Suits writes about Kallas' opportunities as a writer in connection with limits and restrictions. "In der Begrenzung liegt die Kunst [Art lies in restrictions], he quotes in German and adds, "all else is dilettantism. In my opinion, this was the leading idea of my review"16 (Andresen 1996, 150). At the same time, Suits adds that Aino Kallas was still one of the best and most promising contemporary Finnish woman writers, and remarks that Eino Leino is of the same opinion. Suits fully approves of Kallas' idea of depicting universal problems through Estonian life and themes in the future, but says about her plans about taking roots neither in Finland nor Estonia but in the humankind that they were "beautifully felt, but vaguely thought" ${ }^{17}$ (Andresen 1996, 150). But, he also wrote, "the deeper you penetrate and the higher you rise, the less you will be able to feel at home at any place and to become 'one of them' either in Estonia or in Finland. But you can least be adapted to the Tartu bourgeois society - no, never, if you want to remain true to yourself! True to yourself and to your art!" 18 (Andresen 1996, 151). Here, we can see a hint of a future conflict. In his views of society, Suits attempted to connect two fashionable authors of the time, Nietzsche and Marx, and arrived at an anti-bourgeois position. From here logically followed a rebellion against the previous authorities, a classical "murder of the father", including Suits' speech about Jaan Tõnisson, held in two parts in Tartu on April $7^{\text {th }}$ and $21^{\text {st }}$ 1913. Young Estonia meetings with presentations were a tradition at that time, but this presentation was exceptional because of the fact that it was postponed several times, obviously, for its subject ("Jaan Tõnisson's social activities"). The first time, the large hall of the Vanemuine theatre was not full, but the number of people was sufficiently large, including the Kallas family and Jaan Tõnisson. According to a researcher of a later time, the presentation was "somewhat disconnected, where generalising observations altered with attacks against personality"19 (Haug 2004, 82). Discussions became so animated and took so long that Suits interrupted his presentation and promised to complete it at the next meeting. This was not a clever media trick, but by the words of contemporaries, Suits simply did not wish to risk continuing. He had thoroughly prepared only the first part of his presentation and he continued by following only an outline. He did not risk going on in this way in such a polemical atmosphere.

More than 1200 people came to listen to the second half of his presentation on April 21 ${ }^{\text {st. " }}$ "The presentation that went on for about two hours was not as much a continuation of the first half, as an attempt to tackle the whole subject anew and in a more successful way" ${ }^{20}$, writes a later researcher, Toomas Haug (Haug 2004, 86). In his study, Haug reconstructs the points of the presentation (its text has not been preserved and despite repeated promises, Suits never published it) by examining overviews published in contemporary newspapers. Supposedly, Suits recognised Tõnisson's great role in the past as the uniter of Estonian people in their fight against Baltic-German privileges. Later, when society became differentiated, Tõnisson remained a representative of only one class - the moralising bourgeoisie. Suits' presentations supposedly contained many attacks against Tõnisson's personality, discussions of his business affairs, and accusations in demagogy. According 
to Suits, Tõnisson had given up ideals and become a politician of the reigning power in order to gain personal benefits (Haug 2004, 85-87).

The result of the presentation was, from Suits' viewpoint, a catastrophe - even those who opposed Tõnisson did not support Suits but rather, expressed their malicious delight. The so-called conservative wing of Young Estonia, including Aino Kallas, Villem Grünthal, and Johannes Aavik, announced in the press that they did not support Suits' position and especially, did not approve of the tone of his presentation (Haug 2004, 90). Suits became embittered; naively, he had apparently hoped for greater understanding, from Aino Kallas as well. Later, he commented in his letter to Tuglas,

Mrs. Kallas has lately become a champion of the right wing of Young Estonia.... I could understand it if Mrs. Kallas were an admirer of Napoleon. But to admire Tõnisson - - ! It seems to me that our friend Aavik did not strike very far from the truth with his paradox explaining that Mrs. Kallas fears her husband even in her works! ... Our friend Aavik is a cynic"21 (Andresen 1976, 144).

Aino Kallas only notes briefly in her diary, "Yesterday, there was a long talk concerning Suits' presentation about Tõnisson at Young Estonia. My illusions about Young Estonia are gone; I feel that I will be left alone, just like I always have been" ${ }^{22}$ (Kallas 1953, 291). A more permanent creative separation did not however, occur. Suits' long essay about Aino Kallas had been published in Finland in 1909 (magazine Valvoja, No 11) and in Estonia in the Young Estonia magazine in 1910. Aino Kallas published an essay of the same style, "Gustav Suits lüürikuna" [Gustav Suits as a Lyricist] in 1915; a revised version of the essay was included into the book Nuori Viro. Thus, in social communication, Aino Kallas chose the side of Oskar Kallas and Tõnisson, but regarding her creative work, she still remained among Young Estonians. Balancing on these frontiers probably sharpened her eye for clearsighted analysis of Estonian society and literature. In her introduction to the book Nuori Viro Kallas characterised the generation drawn to Tõnisson as roadmakers for Young Estonians. She never emphasised the antagonism between the young and the old, so obvious to her contemporaries, in her public texts, but always pointed at continuity. She expressed her unhidden support to the creative work of Young Estonians, highly appreciating Tuglas' short stories and Suits' and Grünthal's poems.

We can see in Aino Kallas' diaries that she was much more interested in what Juhan Luiga did, thought, wrote or talked about than in the aesthetic and social antagonisms between Suits and Tõnisson. By his views and the year of his birth, Luiga, too, rather belonged to the camp of Tõnisson more than that of the Young Estonians, but on several issues his opinions were much more liberal, and with his characteristic love of paradoxes he even reproached Young Estonians for not being radical enough and for not reaching sufficiently far out in their search for new ideas and methods. It is clear that in such a polemical atmosphere, Kallas' literary views acquired a much more precise shape and she had to develop society, art, and patriotic views for herself very clearly. Among other problems, Kallas had to think about her role in the radically changing Estonian literature of the time. 
When searching for themes for her work, she arrived at the greatest legend of Estonian literary life: Lydia Koidula (see Olesk 1992). This was not exactly a discovery of previously unknown areas for Kallas; already earlier she had compiled and translated into Finnish a book of Estonian fairy tales (Wirolaisia kansansatuja, [Estonian Fairy Tales], 1910) and a book of poetry (Merentakaisia lauluja, [Songs from Overseas], 1911). The latter had a long and exhausting introduction that, having largely been based on Gustav Suits' overview Estnische Literatur [Estonian Literature], (1908), offers a balanced but critical overview of Estonian literature up to that time. Similarly to Gustav Suits, Kallas also thought that besides folk songs, very few works of literary value could be found in earlier Estonian literature, and that more interesting period in Estonian literature began only in her contemporary time with the works of Young Estonians.

Kallas acknowledged the meaning of Koidula as a poet in Estonian literature, but with a local, not universal meaning. She was interested in Koidula as a person, as a woman, and not only as a writer. The more she learned about the life of the real Lydia Jannsen, the more she started to connect her own fate and that of Koidula's. Her primary source was Koidula's correspondence, published in Estonia in 1910, with another great figure of the period, the creator of Estonian national epic Fr. R. Kreutzwald. The difference between the ages of the correspondents was 40 years; Kreutzwald had reached the twilight of his life and Koidula was only on the threshold of her success. Mutual understanding and liking, at first, then great admiration from Kreutzwald's side and later also feelings of offence, shaped this correspondence into a thrilling cultural, historical, and psychological romance. ${ }^{23}$

Koidula had been corresponding with a man whom Aino Krohn knew - Antti Jalava, the father of her best friend Ilona Jalava, whose name was Antti Almberg at that time. What's more, during her trip to Finland, Koidula had evidently fallen in love with Almberg, who had not answered to her feelings. This disappointment had led to Koidula's hurried marriage where, in Kallas' opinion, there was no spiritual understanding and harmony between the spouses.

Kallas found even more episodes in Koidula's life that affirmed her motives for identifying with it: Koidula had expressedly been her father's daughter, and Kallas felt the same towards her father. Koidula's father Johann Voldemar Jannsen had been an initiator of the Estonian national movement and one of its leaders, the editor of a large newspaper, and the organiser of song festivals. An outstanding figure of the Finnish national movement, Julius Krohn had stopped at the Jannsens' home during his trip to Tartu in 1867 and met Lydia. Aino started her literary activities symbolically under her father's pen name Suonio and always felt to be a descendant of the Krohns, not of her mother's family. Koidula had married a man whose mother tongue differed from hers and who even did not speak the language of her works. Oskar Kallas was able to read what his wife had written, but during the Tartu period, Aino probably often felt that her husband, despite all his goodwill, was not able to understand the intrinsic message of her work, her thirst for beauty and life, because he was not a native of that language - he was entirely something else. Kallas also felt empathy with 
Koidula's obligation to divide her strength between her creative work and her children, and with her compelled exile from her country of birth. Koidula's spiritual, but at the same time also concealed erotic relationship with Kreutzwald could have, in her mind, reflected her own relations with Jaan Tõnisson or Juhan Luiga. But what was more important was that Koidula was a woman, and an artist. All the problems that creative work brought into the life of a housewife were important and sometimes even painful for Aino Kallas. Tähelend was Kallas' first book, where she discussed the theme of a woman artist; later, she returned to the subject once more (see LeskeläKärki 2006, 562-568).

Aino Kallas moved between Finland and Estonia especially often after WWI, when her love for Eino Leino made her spend long periods of time in Helsinki. This feeling overshadowed, at least in her diary, the end of the war, revolutions in St. Petersburg, and Finland and Estonia's path towards independence. This was followed by the period when she lived in Helsinki for three years as the wife of a diplomat, the Estonian Ambassador in Finland. This return home is reflected in her work as a return to her roots; Kallas wrote a novel of childhood titled Katinka Rabe (1920). Her search for her place between Estonia and Finland (spiritually, it was the choice between Oskar Kallas and Eino Leino) finds an unexpected solution - the Kallas family moved to London. It was a very favourable and happy solution for Aino Kallas; the backdrop of her personal drama was replaced by the panorama of the wide world. Kallas had yearned for the world, for spaciousness and for success already for a long time. Based in London, she wanted to proceed to conquer the wide literary world, to create a position for herself as an international writer. She also hoped to improve decisively her position in the Finnish literary sphere, where she felt "marginal". She wanted to "conquer London" ${ }^{24}$, in order to arrive in Finland via England and the world (Kallas 1955, 55-56). Characteristically, at this time she was worried about her position in Finland, not in Estonia where, in the early years of the Estonian Republic, it already was as firm as that of all other Young Estonia writers. At first, Kallas enjoyed the spaciousness that London offered. Ultimately, she felt real superiority over narrow national confines and was able to find her true position between Estonia and Finland; in general, we could say that in England she behaved as a citizen of Estonia and as a Finnish writer.

During the years spent in London, Kallas sometimes wanted to reproach both of her homelands: in Finland, her applications for financial support for publishing her translations were repeatedly rejected; in Estonia, strange scandals, seemingly caused by simple human envy, surfaced now and then. ${ }^{25}$ She was annoyed by this, but her self-confidence was not shaken; this was the time when her work spread across language borders, she was known in London and translations of her works were published in several countries. Her illusion of taking root in humankind seemed to be closest to its realisation. She did not think about the real Finland or Estonia, but about what she saw and heard in London and in her travels (we can read in her diary that she was interested in the conditions of Negroes in America and women's conditions in Morocco). During the safe pre-war period, she regularly moved between London, Helsinki, and Kassari. She had sketched this model 
in her diary already in 1925: "Winter home in Finland, summer \& work home in Estonia and in between, some months in the wide world" ${ }^{26}$ (Kallas $1955,203)$. Her attitudes as a woman of the world and belief in her own talent spurred her on towards great success.

In the 1920s, she had instinctively found the subjects and the style that liberated her from the influences of the narrowly national (either Finnish or Estonian) literary fashion. "Taking roots in humankind", discussing eternal issues in the shadows of historical backdrops, gave her independence. All literary advisors and critics, who helped her to further her literary career, pointed out that her works will never find a wide readership, but will delight the chosen few. Her literary work, which was more and more widely translated, stood apart from the literary mainstream of both of her countries and she was the writer of two countries, being still "ultimately, a quite solitary writer" ${ }_{27}$ (Laitinen 1995b, 330).

At the time when Aino Kallas' prose ballads were published (and translated), Estonian literature was dominated by an entirely different genre - realist and naturalist prose. The new generation, who had fought in the Liberation War, raised their banner "Closer to life!" and rejected the Europeanness of Young Estonians. They thought that first of all it was necessary to deal with Estonian themes. Aino Kallas had found the plots of her works of the time (Barbara von Tisenhusen, Reigin pappi [The Rector of Reigi], Imant ja hänen äitinsä [Imant and His Mother] from the old German-language chronicles about Estonian history or from Estonian folklore (Sudenmorsijan [The Wolf's Bride], Pühän Joen kosto [Revenge of the Holy River] (see Laitinen 1995b). Kallas has given hints and several researchers have discreetly referred to great storms of passions in her life that have in a hidden way been written into these works. In 1913, she complained that she had not yet lived long enough to gain experience, but she had already experienced passion and pain that she used as psychological backgrounds for her historical works. The personal material is well hidden; her contemporary reader was probably not able to understand these works in such a way. Kallas hid herself well - her historically truthful plots were presented in archaic language, which made the distance between the reader and author even greater.

Besides all other aspects, which have so convincingly and interestingly been written about by Finnish feminist literary scholars (see, e.g., Melkas 2006), these works are also stories about Aino Kallas' personal boundaries, which she did not dare to cross in real life. She did not cross the boundary, but living and touching art was born on this boundary. In a simplified way, we can say that Aino Kallas allows her woman characters (Barbara, Catharina, Aalo) to cross all the boundaries that she herself had not dared to cross in her life. Upon crossing boundaries, self-realisation and self-proving ends tragically for these women - the price is death. The most persistent image that, judging by Kallas' diary of the period when she lived in Sweden, accompanied her until the end of her life is Diabolus Sylvarum (the Spirit of the Forest, also the Demon of Creation) from her Sudenmorsijan; in later years she attempts, repeating it like a mantra, to preserve her waning creative power (Kallas 1957). A touch of a brilliant creator, as she interpreted 
her relationship with Eino Leino, had lit such a power of creation in her that "liberated her forever" ${ }^{28}$ (Kallas 1955, 223). She, who accepted limits and restrictions in real life, still celebrated in her works the crossing of boundaries at the price of one's life.

Friedebert Tuglas was the one to translate the majority of Kallas' works into Estonian. Tuglas was a kindred soul to Kallas; his development had, in outline, progressed side by side with Kallas' creative pursuits. When Tuglas' creative power faded in the early 1920s, he wrote criticism and essays, edited magazines and became an acknowledged and authoritative leader of Estonian writers for decades. Like for Kallas, short story was also his main genre, and in his short stories he strove to surpass ordinary realism and achieve a mythical dimension.

Even more of such accidental parallels can be found in the works of the two writers: Tuglas, too, overcame a long pause in his creative work by writing a novel about his childhood. Although Väike Illimar [Little Illimar] differs quite extensively from Katinka Rabe, they are related by the atmosphere of the memories, a special kind of softness when the authors attempt to find their roots and get some solid ground beneath their feet. During WWII, Tuglas, too, started a historical novel, but later, he decided that only a part of it was ready to be published, in the form of a short story ("Käsu Hans"), and it is very difficult to guess at the style of the novel he had planned on the basis of this short fragment. It is still clear that it had not been meant to be written in an archaic style.

In the 1920s, Tuglas had translated Aleksis Kivi's Seitsemän veljestä [Seven Brothers] into Estonian, and although linguistic problems connected with this work were different, it was still a good preparation for dealing with Aino Kallas' archaic style, which was novel in the Estonian language. Tuglas translated Kallas' prose ballads keeping true to the author's style and phrasing, choosing Estonian words mostly from the 18th-century translation of the Bible, as the German-language chronicles where Kallas had found her plots had not been translated into Estonian. Although Tuglas' translations were published about seventy years ago, they are still repeatedly reissued in Estonian, because a language that has been styled to be archaic does not become outdated like everyday language. Estonians have accepted this language, which is, usually but unfairly, taken to be Tuglas' own language. Jaan Undusk's comments on Reigin pappi [The Rector of Reigi], quoted at the beginning of this article, contain the following idea: "Kallas has a much weightier position in Estonian literary history and in the minds of Estonian readers than in Finland. Translator Friedebert Tuglas, who styled the majority of Kallas' short stories into rhythmic and powerful Estonian prose, has here played a large role. Without Tuglas' translations, Jaan Kross would never have developed into an author of historical prose" ${ }^{29}$ (Undusk 2008). What does this mean? Undusk obviously refers to the rich and baroque language that Jaan Kross has used in his novels to paint historical backgrounds to his plots. Kross has consciously avoided the use of archaic linguistic forms, but his vocabulary is extraordinarily rich. Undusk is one of the best scholars of Jaan Kross in Estonia. Has he found a relation that has so far been unnoticed - the indirect influence of Kallas' 
works and their translations into Estonian by Tuglas on the style of Kross' historical novels?

Kallas' works have been read differently in Finland and Estonia. This was noticeable already at the beginning of her literary career, when Gustav Suits wrote, "As the Finnish review mostly noted that Aino Kallas has, with her Estonian themes, brought something new and interesting into Finnish literature, then Estonian critics should pay more attention to the fact that something praiseworthy and interesting has reached Estonian literature from across the sea. Its exact nature could shortly be called good style" ${ }_{30}$ (Suits 1910, 58).

Such difference between the viewpoints has, mutatis mutandi, been preserved throughout history. In Finland, supported by feminist literary studies, the talk is about the fate of women, especially creative women; in Estonia, it can be examined as the style-creating basis for Estonian historical prose.

\section{Notes}

1. [Aino Kallas on neid haruldasi eesti kirjanikke, kelle peateosed ei ole sündinud eesti keeles.]

2. The Tartu Renaissance refers to the appearance of Estonians in the politics formerly influenced by Germans and Russians. Its leading forces were Estonian students at the University of Tartu who had gathered in the Estonian Students' Society. It was a national and cultural movement; its members founded different societies, economic enterprises, Estonian schools, and demanded equal social and political rights for Estonians. These people were the first educated Estonians who consciously used the Estonian language as their home language (up to that time, educated Estonians had spoken German at home).

3. The so-called "church-kitchen-children" model defined and limited women's role in the $19^{\text {th }}$ century and early $20^{\text {th }}$ century Baltic German families. The church, housework (the kitchen) and childcare constituted the spheres that were deemed appropriate for women Baltic German society.

4. [Minulla ei ole enää isänmaata - ei isänmaata! Se on surua, suurta, pohjatonta, epätoivoista surua! ... minun maani, minun kansani, minun kallis kansani!]

5. [... virolainen nainen, virolaisen miehen vaimo ja yksi Eestin tyttäristä.]

6. [Minä olin kasvatettu fanaatikoksi, ainakin kansallisuusasiassa, - vähitellen olen muuttunut täysin tolerantiksi, silti urhaamatta kosmopolitismille. En tahtoisi sanoa suvaitsvaisuuden taipumukseni olevan väliäpitämättömyyttä, se on seuraus siitä, että olen vasten tahtoani tullut irtirevityksi omista oloistani ja sentähden pakoitettu niitä objektiivisesti katselemaan, samoin kuin niitä vieraita oloja, joihin en voi niin orgaanisesti eläytyä, että kadottaisin kriitillisen kannan. On yksi sana, jolla minulle on yhä enemmän viehätystä, se on sana „humaani”, - se kangastaa edessäni kaukaisena ihanteena, ymmärtävä, rakastava, korkea humaanisuus, joka ihmistä semmoisenaan ylinnä pitäen...]

7. [ ... taiteen kannalta toisen luokan teokseen.]

8. [Syksyllä olen joutuva kirjailijapiireihin, ja tiedän edeltäpäin, että tulen niissä viihtymään.]

9. [...mutta jos kerran joku on pannut johonkin teokseen kaikki voimansa,mitkä hänellä sillä kehituskaudella on, niin on yleisön velvollisuus auttaa häntä sen ke- 
hityskauden yli lukemalla hänen kirjansa ja arvostelemalla sitä. Ei mikään niin hyödytä ja kasvata kirjailijaa kuin tulla julkisesta kritiikistä osalliseksi. Minäkin tarvitsen tätä kirjaani välttämättä portaaksi, josta sitten voin sekä taitellisuudessa että aiheen puolesta korkeamalle asteelle kohota. Jos se jäisi makamaa laatikkoon, olisi kehitykseni pitkiksi ajoiksi katkaistu.]

10. [sisin, syvin, vuorenvarma (tiedo taiteilijankutsumuksestan).]

11. [ taistelu äidinrakkauden ja taiteilijanlahjani välillä...]

12. [ Siitä ei tulisi kuiteenkaan onnea, lasten kasvatus ja kansallisuussuhteet muodustuisivat liian vaikeiksi.]

13. [ Sähköä kulki läpitseni, mutta hervahdin pian taas. Miksei sanottu tätä kaikkea kerran ennen, kahdeksan, yhdeksän vuotta takaperin, silloin kun sitä niin kaipasin ja salaisesti tunsin ansainneeni. ...Ei kukaan ole minua maininnut missään, ja nyt yhtäkkiä: kirjaani on ododettu ,suurin toivein.” ...Minulla ei ole aiheita, siinä on syvin syy; sieluni ei ole sittenkään pohjia myöten järkkynyt, mistä kirjoittaisinkaan? Ulkonaisista aiheista en enää halua kirjoittaa, mutta mikä on minun sisäinen elämykseni, jollei ehkä juuri elämättömyys, jonkunlainen alituinen, kaikkea tappava teoreettisuus?]

14. [käsitellä yleisinhimillisiä probleemoja, mutta virolaisin henkilöin.]

15. [Kuna meie Ants Raudjalas nõnda siis suure hulga relativilisi väärtusi oleme võinud kätte näidata, on meile kõigest eelolevast selge, et sel mitte absolutilist meistritöö väärtust ei või olla.] This review was published only in the newspaper Elu through five issues (No 109-12 and 114/ 22-31.12.1907). In general, Suits repeats his views about the novel in a wider overview of Aino Kallas' works (see Suits 1910).

16. [ - kõik muu on dilenttantismus. See oli minu enese meelest minu arvustuse juhtiv mõte.]

17. [Kaunisti tuntud ...kuid vähe uduselt mõeldud.]

18. [Mida sügavamale teie aga tungite ja mida kõrgemale tõusete, seda vähem võite Teie kusagil koduneda, üheks „neistsinastest” saada, olgu see siis Eestis või Soomes. Kõige vähem võite Teie aga Tartu kodanlise ringkonnaga koduneda - ei, ei, ialgi, kui Teie enesele tahate ustavaks jääda! Enesele ja oma kunstile!]

19. [hüplik, üldistav vaatlus vaheldumas isikuvastaste rünnakutega.]

20. [Ligi kaks tundi kestnud kõne ei olnud niivõrd eelmise jätk, kuivõrd katse kogu teemat uuesti ja õnnestunumalt sarvist haarata.]

21. [Pr. Kallasest on viimasel ajal NE parema tiiva eestvõtja saanud. ... Ma saaksin aru, kui pr. Kallas Napoleoni imetleja oleks. Aga Tõnissoni imetleja - ! Vahest ei ole sõber Aavik oma paradoksidega tõesti mitte väga kaugele trehvanud seletades, et pr. Kallas oma meest isegi oma töödes kardab! - Sõber Aavik on küüniker.]

22. [ Eilen oli Noor-Eestissä pitkä keskustelu Suitsin Tõnissonia koskevan puheen johdosta. Minun illusioonini Noor-Eestin suhteen ovat menneet, tunnen jääväni yksin, kuten aina olen ollut.]

23. Based on this correspondence, Aino Kallas wrote two essays in 1911, and characteristically to her, published them in two different publications: in the magazine Noor-Eesti No 5/6 and in the collection of articles Eesti kultura I [Estonian Culture I], issued by Tõnisson's wing. In Finnish, these essays appeared in the magazine Valvoja 1912 (No 1 and 11). All these essays were titled "Koidula ja Kreutzwald" [Koidula and Kreutzwald].

24. [valloittaa Lontoo.]

25. An article written by August Alle titled "Jaanalinnu sulgedega" [With the Ostrich's Feathers] 1924 provides a good example (see also Laitinen 1995b, 50-52). How she represented Estonia in her travels was also seen problematic (Laitinen, 1995b, 53-54) and finally, her play Mare ja hänen poikansa [Mare and Her Son] was prohibited (see Laitinen, 1995b, 351-360).

26. [Talvikoti Suomessa, kesä+työkoti Virossa, välillä joku kuukausi suuressa maailmassa.] 
27. [ . ..aika yksinäinen kirjailija.]

28. [vapautti minut ainaiseksi.]

29. [Eesti kirjandusloos ja eestlase teadvuses on Kaldal märksa kaalukam koht kui Soomes. Oma panuse selleks andis tõlkija Friedebert Tuglas, kes stiliseeris suurema osa Kalda jutte rütmiliseks ja sõnajõuliseks eesti proosaks. Ilma Tuglase tõlgeteta ei oleks mõeldav Jaan Krossi kujunemine ajaloolise proosa viljelejaks.]

30. [Kuna Soome arvustus tähelepanekut pääasjalikult selle pääle on juhtinud, et Aino Kallas omade Eesti ainetega midagi uut ja huvitavat Soome kirjandusse on toonud, vôiks Eesti poolt selle pääle rôhku panna, et Mere tagant novellide ja Ants Raudjala tôlgete kaudu ka midagi tänuväärilikku ja huvitavat ka Eesti kirjandusse on tulnud. Mida nimelt, seda vôiksime lühidalt ehk hääks stiiliks nimetada.]

\section{References}

\section{Research Objects}

Kallas, Aino 1952: Päiväkirja vuosilta 1897-1906. [Diary from the Years 1987-1906.] Helsinki: Otava.

Kallas, Aino 1953: Päiväkirja vuosilta 1907-1915. [Diary from the Years 1907-1915.] Helsinki: Otava.

Kallas, Aino 1955: Päiväkirja vuosilta 1922-1926. [Diary from the Years 1922-1926.] Helsinki: Otava.

Kallas, Aino 1956: Päiväkirja vuosilta 1927-1931. [Diary from the Years 1927-1931.] Helsinki: Otava.

Kallas, Aino 1957: Vaeltava vieraskirja vuosilta 1946-1956. [Wandering Guestbook from the Years 1946-1956.] Helsinki: Otava..

Kallas, Riitta 1988: Kolme naista, kolme kohtaloa. Aino Kallaksen kirjeenvaihtoa Ilona Jalavan ja Helmi Krohnin kanssa vuosina 1884-1913. [Three Women, Three Destinies. The Correspondence of Aino Kallas with Ilona Jalava and Helmi Krohn from the Years 1884-1913.] Helsinki: Suomalaisen Kirjallisuuden Seura.

\section{Archival sources}

Letter of Aino Kallas to Oskar Kallas (6. 03. 1902). KM EKLA f 186, m 57:61.

\section{Research literature}

Andresen, Nigol 1976: Gustav ja Aino Suitsu kirjad Friedebert Tuglasele. [The Letters of Gustav and Aino Suits to Friedebert Tuglas.] In: Paar sammukest eesti kirjanduse uurimise teed. uurimusi ja materjale IX. [A Few Steps on the Road of the Study of Estonian Literature. Studies and Sources IX.] Tartu: Eesti NSV Teaduste Akadeemia F. R. Kreutzwaldi nimeline Kirjandusmuuseum.

Andresen, Nigol 1996: Gustav Suitsu kirjad Aino Kallasele. [The Letter of Gustav Suits to Aino Kallas] In: Eesti Kirjandusmuuseumi aastaraamat. Paar sammukest XIII. 
[The Yearbook of Estonian Literary Museum. A Few Steps XIII.] Tartu: EKM.

Haug, Toomas 2004: Isad ja pojad. Gustav Suitsu kõne Jaan Tõnissonist aastal 1913. [Fathers and Sons. The Speech of Gustav Suits on Jaan Tõnisson in 1913.] In: Troojamäe tõotus. 33 kirjatööd [The Oath of Troojamäe. 33 Essays.] Tallinn: EKSA.

Laitinen, Kai 1995: Aino Kallas 1897-1921. Tutkimus hänen tuotantonsa päälinjoista ja taustasta. [Aino Kallas 1897-1921. [A Study of the Main Topics and Background of her Work.] Helsinki: Otava. (1995a)

Laitinen, Kai 1995: Aino Kallaksen mestarivuodet. Tutkimus hänen tuotantonsa päälinjoista ja taustasta 1922-1956. [The Master Years of Aino Kallas. A Study on the Main Topics and Background of her Work 1922-1956.] Helsinki; Otava. (1995b)

Leskelä-Kärki, Maarit 2006: Kirjoittaen maailmassa. Krohnin sisaret ja kirjallinen elämä. [The Krohn sisters: Lives in writing.] Helsinki: Suomalaisen Kirjallisuuden Seura.

Lotman, Juri M. 1992. O semiosfere. Isbrannõe statji I. Statji o semiotike I tipologii kulturõ. [On the Semiosphere. Collected Works I. Works on the Semiotics and Typology of Culture.] Tallinn: Aleksandra.

Melkas, Kukku 2006: Historia, halu ja tiedon käärme Aino Kallaksen tuotannossa. [History, Desire and the Serpent of Knowledge in the Works of Aino Kallas.] Helsinki: Suomalaisen Kirjallisuuden Seura.

Olesk, Sirje 1992: Aino Kallas ja Koidula. Autor ja tema kangelanna. [Aino Kallas and Koidula. The Author and her Heroine.] Keel ja Kirjandus 5.

Olesk, Sirje 2003: Aino Kallas ja noor eesti kriitika. [Aino Kallas and Young Estonian Criticism.] Keel ja Kirjandus 8.

Suits, Gustav 1907: Aino Kallas. Ants Raudjalg. Elu 114, 2

Suits, Gustav 1910: Aino Kallas novellikirjanikuna ja luuletajana. [Aino Kallas as a Novelist and and a Poet.] Noor-Eesti 1910:1.

Undusk, Jaan 2008: Aino Kallas. Reigi õpetaja. [Aino Kallas. The Rector of Reigi]- Eesti Päevaleht 28. XI 2008. 


\title{
"The suitcases in my room"
}

\author{
Aino Kallas as a Traveller and a Travel Writer
}

The simple phrase "the suitcases in my room" is to be found in Aino Kallas' diary entry for the $23^{\text {rd }}$ of May $1930(1956,255)$. Only a few words but full of meaning and symbolism: suitcases referring to travelling and the room to a place of her own, a place between journeys. Seventeen years later, at the age of sixty-nine she looked back on her life, remembering her homes in four different countries: Finland, Tsarist Russia, Estonia and Great Britain. It is touching to read her description of the last years in Stockholm, Sweden. She felt that she had ended up totally homeless, living in "reed cottages" (Kallas 1946, 220). Kallas summarises her life in her book Kolmas saattue kanssavaeltajia ja ohikulkijoita [The Third Group of Travelling Companions and Passers-By], published in 1947:

My whole life has been like a swing of a pendulum between two opposites: a strong attachment to home and an irresistible wanderlust. One after another I have heard their call and obeyed it, as if it were an ancestral command, and I cannot tell which one has been the strongest. Both have given me total and profound satisfaction, and by obeying them I have made real my true, my inner self. (Kallas 1947, 176.) $)^{1}$

Kallas regarded these opposite forces - a strong need to settle down and an urgent need to travel - as the basic polarities of her life, as elementary parts of her self-identity. She explained that this restlessness was due to her bloodline, the 'vagrant' Krohn family. In her diaries she refers to her sister Aune Krohn's comment that their family is able to sleep soundly both on feathers and on straw, and recognizes this adaptability in herself, too.

Texts dealing with Kallas' travels are found in her diaries, letters and memoirs and, especially, in her three books Langatonta sähköä [Wireless Electricity] (1928), Löytöretkillä Lontoossa [Exploring London] (1944) and Marokon lumoissa [Under the Spell of Morocco] (1931). Of her constant wanderlust, even Weltschmerz, she wrote as early as 1908 in her diary, wondering what will be left to long for, when the earth has no charms of novelty to offer anymore. The stars? $(25.6 .1908,1953,86$.) She expresses a similar worry twenty years later by predicting that when the last corner of the earth has been explored and The Unknown has ceased to exist, the planet will 
become all too small. (Kallas 1928, 62.)² She begins Marokon lumoissa by questioning man's need to travel: Why do people travel? To escape from themselves, from others? Or are they driven by eternal curiosity and their inner insatiable nature - or do they want to find themselves, or the volcano of Indrapoera on the island of Sumatra? (Kallas 1931, 8.) ${ }^{3}$

How did Aino Kallas answer the call of her wanderlust? What was she searching for? To answer these questions I continue representing Kallas first as a traveller and then as travel writer, though these two sides are interwoven. In the last part of my article I focus on her representations of Moroccan women. Her texts remind us that travel narratives are written by strangers. It is the outsider's point of view that dominates such texts. One of the main questions is how the narrator confronts the foreign and the unfamiliar, and how she textually produces sameness or difference.

\section{Conquering London and gaining peace in Kassari}

A journey can, in short, be conceptualised as the movement and space between leaving and returning home. In Aino Kallas' case it is important to consider where her home was and how its changing locations influenced her journeys. The title phrase - the suitcases in my room - was written in London; the Estonian Embassy, at 167 Queen's Gate, Kensington was the place for the departures and arrivals described under it. The Kallas family settled there in January 1924 when Oskar Kallas was appointed the ambassador of Estonia in Britain and Holland. They stayed in London until the summer of 1934 . The family had to adapt to the British aristocratic way of living and the etiquette required, and this, at times, could be quite suffocating. Later Aino Kallas visited London three times, in 1936, 1938 and finally, in 1953, only three years before her death. In spite of her sometimes very ambiguous feelings towards the city, the London period was of great importance to her.

In the 1920's, Britain and London were still rather unknown in Finland, The Finnish Embassy in London (2 Moreton Gardens, South Kensington) was a meeting place for a small but influential group of Finns. With their articles and books they made Britain familiar to their countrymen. In London studied also Elsa Enäjärvi who later was one of the first Finnish female scholars and also known as an active debater. It was agreed that she would write Kallas' biography, but her early death prevented it. ${ }^{4}$ She even lived for a while with the Kallas family before moving into Crosby Hall, a residence hall for academic women. She fell in love with London and with everything English and published a book called Vanha iloinen Englanti [Merry Old England] (1929). The book was received enthusiastically, the critics praising it for introducing to Finnish readers a then rather unknown subject. A similar reception was granted to Kallas' sister Helmi Krohn's Englantia oppimassa [Learning England/English], (1931) and Kersti Bergroth's and Alex Matson's short-lived cultural magazine Sininen kirja [The Blue Book] (1927-1930).5 Alex Matson was a very important acquaintance for Kallas, and later became her English translator. 
Besides her diplomatic duties Kallas also worked actively to promote her own literary career. She understood that if she wanted to gain public recognition as a writer she needed contacts and access to the literary circles. Kallas' biographer Kai Laitinen has listed her London societies, her most important personal contacts and the different clubs to which she belonged. Laitinen describes these circles as aristocratic; Kallas' contacts with more bohemian groups were notably fewer. (Laitinen 1979, 37-86.)

Kallas' diaries highlight how determinedly she acted to 'conquer London'. She describes her relationship with the city as a wrestling match with a giant. In 1923 she wrote that she had beat him, and the beast was transformed from hostile to friendly and supportive $(22.6 .1923,1955,95 .)^{6}$ At the beginning of the next year she felt that she was standing on the doorstep of fame, engaged with this amazing giant $(17.1 .1924,1955,137) .^{7}$ A couple of months later she again thought that there were only two possibilities left: either she overcomes the city or it will kill her $(2.3 .1924,1955,150)^{8}$. A year later she notes that her honeymoon with London was over, $(3.3 .1925,1955$, $172)^{9}$ only to, three weeks later, again declare her love for the city and praise its vastness, which had enabled her to grow $(24.3 .1925,1955,177)^{10}$.

Kallas' journeys were closely connected with both writing and promoting her career. She worked hard to get her books translated into different languages. Another important aspect of her travels were the public lecture tours on Estonia and its culture. Kallas made her first tour of England as early as 1924. This seems almost unbelievable, because the members of the Kallas family knew hardly any English when they arrived in the country. Kallas had studied the basics of English for two years at school and taken some private lessons. Despite this, she was soon admired, not only for her looks, but also for her exceptional language skills. During her grand tour across the Atlantic in 1926 she also gave lectures in the United States and Canada.

Kallas can be regarded as an unofficial 'Estonian cultural diplomat.' Lecturing had many levels of meaning. It might have been easier for a woman to describe her travels as a national duty rather than as means to pursue her own career or pleasure. However, naturally the tours gave Kallas many opportunities to satisfy her wanderlust and advertise her books. She was also able to leave behind her other roles and obligations which for a woman was not otherwise easy or considered suitable.

As a travelling female subject, Kallas implicitly violated gender norms and ideals of motherhood, inviting accusations of being selfish and careeroriented, which still overshadow her reputation as a writer. The diaries illuminate her ambiguous feelings during travelling. Family was the solid basis of her life, and it was hard to leave it behind. In spite of sad feelings at the hour of departure she would soon find pleasure in being on the move again. On the other hand, only the picture of Oskar Kallas could give her comfort and strength in the midst of weariness and excitement. Absence made clear the value of the nearest and dearest, and the importance of the shelter they offered. Kallas never left her home totally, and her journeys both changed and deepened her feelings towards it. It is worth wondering if the divide between home and travels really was as extreme as noted earlier. Were it so, we would have no need for the concepts of homesickness or nostalgia. 
Kallas writes that the tours allowed her to meet ordinary people and to see more of the everyday life in foreign countries, not only museums, churches or street life that a common tourist would experience. With this comment she reveals a very important aspect of modern travelling. When travelling abroad became democratised, it became more important to differentiate oneself from the passive mass of ordinary tourists and to regard oneself as an authentic, active traveller.

The lecture tours were also a good way to finance travelling. Money played an important role, because Kallas wanted to secure her old age and independence and also to free Oskar Kallas from the pressures of work. It is worth pointing out that the family of the Estonian Embassy lived in constant need of money. Kallas faithfully noted down all the income and expenses during her journeys. In 1930 she counted that in three years she had saved 1755 pounds, which was a small fortune, but still insufficient as capital (Kallas' diary 9.4.1930, 1956, 249; see also Leskelä-Kärki 2006, 463-471). Constant touring began to take its toll. Lectures were demanding and timeconsuming. It seems that Kallas learned her speeches by heart, reading them through several times beforehand. Tours became more and more exhausting and even boring, so she decided to give them up, settle down and concentrate on her writing.

During the London period Kallas travelled not only around the 'great countries', she also made frequent trips to Estonia that had a special meaning. It is possible to argue that she travelled between two homes. During her first London years, she was fascinated by the vastness opening up in front of her eyes. She mentions several times that after diving in the ocean she cannot be satisfied with pools anymore. But soon enough she started to suffer from her societal duties and inner restlessness, longing for a room of her own and peace to write. Realising that writing demanded complete isolation, she finally found a place of her own in Kassari, on the island of Hiiumaa. There she had peace, freedom, inspiration and a daily rhythm that she faithfully followed. She praises Kassari and her loyal maid Marie Vets in her book Uusia kanssavaeltajia ja ohikulkijoita [New Travelling Companions and Passers-By] (1946, 55-63). Marie Vets had eagerly adopted the role of gatekeeper, protecting her mistress from all disturbing factors. The recount of Kallas' arrival to Kassari without stopping in Helsinki or Tallinn on the way reveals finely her love for opposites and contrasts: from London and its swirling parties straight to the silence of the sauna and swimming in the sea at Kassari.

It is easy to agree with Kallas when on the 19th of July 1952 she writes in the diary that Kassari and London mirrored the opposite sides of her own character. At that time she feared she had lost them both, "sunken down to the bottom of the sea" (diary 19.7.1952, 1957, 185.) ${ }^{11}$ But she had still got one more opportunity to return to London the next year. She looked for her past and her former self, but had to admit that they were beyond reach, although shadows of the past seemed to meet her at every footstep (Kallas 1957, 256-264.) ${ }^{12}$ Kassari, too, was beyond reach. As an Estonian refugee living in Stockholm, she could return to Kassari only in her memories and imagination. In later years, especially during the sum- 
mer, her longing became nearly unbearable and added to her general feelings of loss.

\section{Life's electricity and memories of the journeys}

How, then to describe Kallas as a travel writer? Travel writings tell not only about places 'not-home' but also about their writers. It is about their choices, values and interpretations. They translate the views and scenes into texts and consider what is worth telling. (See. e.g., Löytty 2006, 210, 255-277.) Concerning Kallas, she herself provided one and very central answer by alluding to herself as a reader of books and an observer of foreign places. She has written widely about the importance of books in her life. Books have sheltered and comforted her in loneliness, sorrow and illness. Considering this, the following confession is worth noting. Kallas reveals that books took second place whenever she got an opportunity to "read a human being, the core of all books" (Kallas 1946, 18). ${ }^{13}$ She describes this further in Marokon lumoissa [Under the Spell of Morocco] writing that all the so-called 'wonders of the East' - the architectural monuments, the ruins from the glorious past, the traditions, national habits and social problems - have paled in comparison with the wonders of human destinies. (1931, 144. ${ }^{14}$ Her interest in human beings overcomes everything else: it reflects Kallas' way of approaching unfamiliar circumstances and characterises her as a travel writer. She concentrated on describing people she met, their destinies and, when at her best, presented through them something more universal and general about the country and its traditions. Using details to evoke a culture as a whole can be seen as a common strategy in travel literature.

Kallas' preoccupation with human destinies is distinctive in Langatonta sähköä, [Wireless Electricity], published in 1928. It consists of nine articles in which Kallas describes the people she has met and the meetings of the International PEN Club, which she regarded as oasis in the middle of the official societal desert.

However, the last article is an exception as it describes Kallas in the melancholy of an English November, reading a biography of the writer Robert Louis Stevenson. Kallas did not especially admire Stevenson as a writer, but esteemed him highly as a wanderer and dreamer who had made his dreams come true. Most of all, she applauded him as a courageous fighter rebelling against destiny, sickness and death. According to her, Stevenson's way of life was a strengthening and empowering example. (Kallas 1928, 122-137.)

Kallas calls her own writings sketches, shallow momentary fragments or 'small letters' about passers-by and travelling companions. This kind of belittling, underestimating can be regarded as a double-edged strategy. Her comments can be interpreted as her gendered mistrust of her own agency and talent as a writer. On the other hand, it can also be a strategy to free her from the conventions of travel literature. Thus she negotiates the position of omnipotent observer. (See, e.g., Lawrence 1994, 15-29.) In the beginning of Wireless Electricity Kallas humbly wishes that she had been able to capture 
in her writing at least a tiny spark of the electricity that has enlivened the objects she describes. This explains the slightly odd sounding title, 'wireless electricity'.

When describing people Kallas emphasises the importance of first impressions because they are the ones that stick in memory. She describes people in careful detail, because she believed that the truth reveals itself through physical acts and gestures, the exterior revealing or hiding their interior world. She confesses that she has often observed human faces so keenly that she has forgotten to listen to what was being discussed.

Her comments about people she met are usually full of admiration and respect, but less so in her description of the writer James Joyce. She does not hide her antipathy in the following sentences:

A man, mousy, timid and furtive, like an animal, which will suddenly sneak into its burrow underground. Or it could also be a mollusc, carefully putting out its antennae. (...)

A man who does not smile, laugh, or talk. (Kallas 1928, 114, 116.) $)^{15}$

Kai Laitinen has pointed to two chapters in Kallas' Wireless Electricity that deal with married couples: in "Me kaksi" [The Two of Us], Lady and Lord Aberdeen (Kallas 1928, 47-61.) and in "Bernard Shawn seurassa" [In the company of Bernard Shaw], Beatrice and Sidney Webb, the founders of the socialist Fabian Society. When visiting them Kallas met George Bernard Shaw, who seems to have dominated the meeting with his long monologues. But Kallas thanks him for his selfishness, because he made such an interesting object of study. (Kallas 1928, 21-37.) Laitinen regards these two articles as examples of Kallas' interest in influential people and the choices they make in life, regardless of their political ideologies. (Laitinen 1978, 48-52.) ${ }^{16}$ The Aberdeens and the Webbs represent clearly opposite views of society and the world.

Furthermore, Kallas has dedicated two chapters to female travellers: Lady (Lilian Mabel Roussel) Richmond Brown and Mrs. Alec Tweedie. While reading her texts it is tempting to think that these women represented her ideals, women who had realised Kallas' own dreams. Both had found their own ways of satisfying their wanderlust. Not only that, it is obvious that Kallas also admired them for their beauty. She calls Lady Richmond Brown "the female explorer searching for The Unknown"(Kallas 1928, 62). ${ }^{17}$ Kallas refers to her work Unknown Tribes, Uncharted Seas (1925), considering it to be as exiting as a thriller. The book describes an adventurous journey. According to Kallas it exposes how thin the layer of civilisation actually is and how easily one can slip back to nature, to the original condition of man. Kallas had met Richmond Brown at a tea-party and was surprised at the contrast between her looks and actions. This adventurous and brave woman turned out to be a very elegant beauty queen. In her, Kallas met a woman who had lost her heart to the 'jungles' and become a stranger in her old social circles. Her words on how for a short moment she had managed to enjoy the glimmering richness of life seem to have moved Kallas. (Kallas 1928, 62-70.) 
Kallas also met Ethel Brilliana Tweedie several times, as one of her regular guests. Mrs. Tweedie's varied and rich life offered much material for a writer interested in human destinies. Through her marriage Tweedie had risen from the middle class to wealth. Her husband went bankrupt and shot himself, leaving his young wife an empty-handed widow with two sons. In order to support her family she started travelling and writing books about her journeys. She travelled to Finland in 1896 and published the story of the journey the next year. ${ }^{18}$ It is worth noting that Through Finland in Carts was the beginning of Tweedie's successful career as a travel writer. Life did not spare Mrs. Tweedie from additional hard blows. She lost both her sons, to the First World War and to an aviation accident. After this she gave up travelling.

According to Kallas, Mrs. Tweedie was born to be a traveller. She portrays her as a woman who still carried traces of astonishing beauty. She recognised a woman who was used to taking care of herself and to taking command. Kallas begins her article by wondering whether to describe Mrs. Tweedie's three rooms as a home, a museum and a world fair or just pieces of the tropical and exotic East in the middle of London; all of her souvenirs demanded that their stories be told. Kallas comments that she could not understand how anyone could write in such intense and noisy surroundings. What did this reveal about the soul of the woman who had created it all, Kallas wondered. (Kallas 1928, 88-102.) In her interesting literary portraits Kallas blends her talent as a novelist and as a travel writer.

Another description of London life occurs in Löytöretkillä Lontoossa [Exploring London], published in 1944. Despite the title she also leads her readers down memory lane, to her travels in the United States and Holland. Two sentences, almost hidden in the text describing the court of England, highlight Kallas' melancholy spirits in her late years:

With tough hands has destiny worn out the once so bright colours of my life. Sometimes it feels like an escape from the hard reality to dwell upon the past, glimpses of the past life under the cut-glass chandeliers of Buckingham Palace offering momentary escape from the harsh realities of everyday life. (Kallas $1944,25.)^{19}$

The years passed and the withdrawal from the diplomatic career allowed Kallas to reveal things she had earlier kept hidden. Her role as the wife of the ambassador had enabled her to see but not to speak aloud. Such is, for example, the case of the slums of East End in London. Very early Kallas wrote in her diary that she wanted to see all parts of the city, and revealed that she had been wandering all around London. On February 61924 she writes that she had finally been to East End in the company of some nurses working there. (Diary 6.2.1924, 1955, 142-144.) Some days later she went to Petticoat Lane, which aroused an almost physical revulsion in her - feelings of pity awoke much later. She saw the people there not as poor workers but as representatives of the masses, even of a lower race. They were beyond help and could not be drawn into daylight. According to Kallas the whole area should have been burned down. (Kallas' diary 11.2.1924, 1955, 
145-146.) When describing the East End and Petticoat Lane she articulates the rhetoric of Other as a social threat, and declares the horrors associated with poverty. Her wanderings in the slums can be regarded as a kind of 'class tripping' or 'slumming', which was popular among the middle class visitors to London. The narrowness, dirtiness and greyness of the quarters terrified but also attracted them. (See, e.g., Stallybrass \& White 1986, 2-5, 126-132.)

Kallas does not hide her horror in Exploring London but is more restrained than in her diary, where she writes that the whole area was a hotbed of criminals, prostitutes and members of the mob. In spite of official efforts to clean the area, "the seeds of slum disease" ${ }^{20}$ kept spreading over and over again. The chapter "Pelastusarmeijan lastenkodissa" [Salvation Army Orphanage] also deals with this horror. Kallas reveals that she had expected the home to be an orphanage and was shocked to find out that the children's destinies may even been harder. The home was a shelter for sexually abused girls. (1944, 112-114.) However, Exploring London is not only about terrifying experiences. Its forty chapters also contain descriptions of the glamour of the court, private homes, the general strike in May 1926, public auctions, warehouses, schools, theatres and restaurants.

Having experienced much of London from high to low levels of culture, Kallas moved on across the Atlantic. The descriptions of her journeys to the United States form an independent part of the book. In her diaries she mentions that she had learned that there were many truths about the States. She remarks that the word 'young' best described the country that contained traces of arrogance, self-satisfaction, insatiability, courage and a bold and experimental spirit. Kallas was especially impressed by the women's colleges - Vassar and Wellesley - at which she lectured. She regarded them as pioneers of internationality, filled with the vital spirit of future. She was taken with the students' healthy outlook, physical fitness and self-awareness. They seemed to have realised the social value of women and were ready to stand for their rights.

Kallas was very sceptical, even hostile to the Chinese and Jewish immigrants but very interested in the circumstances of black people, which she regarded as the most urgent social problem the United States had to face and to solve. Although years had passed since the abolition of slavery, black people were still pariah and the gulf dividing them from white people seemed insurmountable. Bitterly Kallas points out that the coloured seemed to be good enough only as servants. She remarks that she never got proper answers to her questions about the reasons of this racial revulsion, and drew the conclusion that the separations had become an organic part of the white people's unconscious and that changing it would take many generations. Kallas enthusiastically mentions W. E. B. DuBois' work The Souls of Black Folk (1903). According to her, DuBois managed to open windows into the secrets of these souls. He gave language to the mutes. She was satisfied with his historical and social explanations for the problem. The scars of slavery were still deep; the past had destroyed not only the black people's self-respect but also their possibilities for education and a better future. (Kallas 1944, 184-196.) 
After all her travels, Exploring London concludes in Holland, because as the Ambassador of Estonia, Oskar Kallas was obliged to visit The Haque at least twice a year. Kallas recalls their visits to the court, and reminisces how the dancer Anna Pavlova had lain dying at the hotel where they were staying. The book ends with Kallas' calm gratitude towards her way of life. She writes that during a wintry walk on an empty beach with her husband she realised that, after all, they had chosen the best share in life.

\section{The spells of Morocco}

It is possible to regard Under the Spell of Morocco as the most traditional of Kallas' travel writings. The book describes a journey from the middle of December 1929 to the end of March 1930. It tells about Kallas' meetings with a foreign and for her even exotic culture. She describes these meetings with her special way via human destinies. The book is a collection of articles, 'small letters', which were also published in the leading Finnish newspaper Helsingin Sanomat. They were not written during the journey but only after Kallas had returned to London. They were based on carefully detailed diary notes. She writes in the present tense, which erases the time passed between the moment of experiencing and that of writing. (About this kind of strategy see e.g., Melberg 2006, 15-18.) The present tense strengthens the sense of the narrator's immediate participation and her role as an eyewitness.

The reason for this journey is not explicit in the book, but Kallas reveals it in her diary, and later on also in Exploring London and in Kolmas saattue kanssavaeltajia ja ohikulkijoita [The Third Group of Travelling Companions and Passers-by] in the article called "Jouluaatto kesän maassa" [Christmas Eve in the land of summer] $(1947,61-64)$. The main reasons were intrigues in the Estonian Embassy and attacks against Oskar Kallas that weighed heavily on him, calling for a vacation, a quick and total change of climate, a restorative sick leave. Kallas does not publicly reveal her own tiredness, joylessness and dismal spirits. In Tangier she continued writing her short stories Imant ja hänen äitinsä [Imant and his mother] and Pyhän joen kosto [The Revenge of the Holy River]. She could finally relax and write in her diary: "Like a worm I come crawling into the sun from under the pressing floorboards" (29.12.1929, 1956, 209). ${ }^{21}$

Under the Spell of Morocco is a good example of how ambiguous travel stories can be, yet it is just these inner contradictions that are so challenging and rewarding to a researcher. The one and the same text can reveal both the writer's eager curiosity and her reservations, fears and revulsions. It is a kind of duet between fascination and critical attitudes, nearness and distance. Kallas fell under the spell of Morocco, but that did not stop her from naming the chapter that describes their visit to Marrakech's Jewish quarters, mellah, "Löyhkien helvetti" [The Hell of Stenches]. The same ambiguity can be traced through out the book.

The researcher is confronted with difficult questions and forced to consider the term contextualisation. How to distinguish between racism, curiosity and ignorance? Is it possible to write about a foreign culture 
without the personal yardstick against which everything is measured, without automatically considering one's own values as superior? Under the Spell of Morocco raises such questions on its first pages. Kallas wonders at the sight of the Malay crew onboard the ship they are sailing. The strange looking Malayans, "those tropical human beings", ${ }^{22}$ fascinated her so much that she could hardly take her eyes off them. She had to acknowledge the limits of her understanding; she tried to decipher what she saw but failed. The crew remained strange and unfathomable. She calls them children and creatures of nature. For a modern reader it is embarrassing to read Kallas' confession that she was barely convinced of their humanity. (Kallas 1931, 7-13.)

On arrival, Aino and Oskar Kallas first settled in Tangier where they stayed at a hotel crowded with Western tourists. Tangier turned out to be only a threshold between Europe and Morocco. According to Kallas it was not enough for those who wanted to see 'the authentic East'. The travellers moved on to Casablanca, only to find that it too was too westernised and modern for their needs. Only in Marrakech did they find the mysteriousness for which they had been searching. Kallas observed and described everything she saw as a constantly changing play. It was like experiencing a fairy tale. Everything looked magical - people, buildings, arcades. She repeats and renews the Western travellers' traditional way of experiencing the East, through the Bible and The Thousand and One Nights. (See Behdad 1999, 25-29; Melman 1995, 63-76.) The books create a curtain between the observer and the views and sights observed. Seeing the actual landscapes and people makes the images of her readings come alive. The strange and the unfamiliar become familiar, but the curtain also freezes everything into timeless, solid and unchangeable objects. This is the imagined, authentic East that the travellers hope to find.

The Inferno of craft shops and the Jewish quarter, mellah, formed the opposites to the country of a thousand and one nights. In the filthiness and dirtiness of the streets Kallas thought to detect even a hint of bragging immodesty. She does not directly call the local inhabitants dirty, but names it a cultural difference; a difference between ways of displaying and hiding. She ponders whether everything that the west kept hidden was here on display. In the chapter "The Hell of Stenches" it is interesting to notice how Kallas represents the universal through the individual in describing a young Jewish man who had acted as their guide.

\section{Glimpses of the female world}

Kallas writes that she realises what fortunate travellers they have been. In Marrakech an encounter with an Estonian doctor, Mr Peets, and his wife gives a totally new direction to their journey; this meeting opens the doors into private homes. Kallas wonders how different their journey would have been without this coincidence. Once more she is able to make a distinction between herself and other travellers. She remarks that they could have wandered around and looked at the famous sights, but the walled-in private 
world would have remained closed to them. The secrets of the city would have remained as hidden as the faces of women behind their veils. ${ }^{23}$ Becoming acquainted with Dr Peets was the key to private homes which, according to Kallas, were built imitating the work of the shellfish: coarse-grained on the outside, bright mother of pearl on the inside.

In the company of Mr Peets and his wife Aino Kallas gained access to the world of women. Women's closed spaces have inspired travel writers' fantasies about harems full of unrestrained lust, depicted even as disguised versions of western brothels or sites for lesbian passions. The word Harem means sections of buildings accessible only to women, so male travel writers have been forced to turn to second hand sources or their own imagination for their descriptions.

It is possible to read Under the Spell of Morocco in the context of women's orientalism. Its pioneer is Lady Mary Wortley Montagu (1689-1762) and her work Turkish Embassy Letters, 1708-1720 was published posthumously in 1763. She was fully aware that her sex guaranteed her access into the women's interiors, such as Turkish bath-houses. (See Melman 1995, 77-98; Basnett 2002, 229-230.) There has been no common agreement on the interpretations of women's role in orientalism or the value of their role as eyewitnesses. Are they necessary supplements for the masculine orientalist text? Or did women gain in prestige by adopting the male position and thus supplementing masculine orientalist texts? Did women realise the desire tormenting Western people, to lift the veils and penetrate the space, where the final truth about the East was believed to exist? This desire was yet to be fulfilled. (See Yeğenoğlu 1998, 68-94.) Is it possible that the presence and participant observations of the female travellers could lead to a sense of cross-cultural solidarity between women, to mutual understanding and thus to normalising and familiarising their circumstances? Is there not also a danger of interpreting women writer's descriptions literally, as only innocent transcriptions of their personal experiences? It should be remembered that descriptions of experiences are the result of many textual and linguistic strategies. (See Lewis 1996, 127-184.)

Indra Ghose's thoughts about what it means to look at other women from a woman's point of view can be considered to be somewhere between these two standpoints. She writes about fascination between women, but also remarks that the pleasure of looking at differences does not diminish the power of the gaze. It is never only a question of identifying with or relating to another woman, nor desiring her in the strictly erotic sense of the word. According to Ghose, it is also a question of desiring to see, to know and to become more like the idealised feminine Other in a context where the difference between women is repeatedly re-established. (Ghose 1999, 56-60. $)^{24}$

Kallas' work can certainly be interpreted through these different points of view and emphases. She wanted to 'lift the veil' even by resorting to cunning and tricks. She reveals that they had lied about Oskar Kallas also being a doctor, thus managing to persuade two women to expose their faces in the presence of two strange men without being ashamed. According to Kallas, the women agreed to this while blushing and shyly flirting. As for 
many western travellers, so also for Kallas the unveiling was a privileged sign of reform and progress. She interpreted it as a symbol of a new beginning, comparable to western women's rights to vote and be elected to the parliament.

She writes about women at two opposite extremes. In the chapter "Muftin haaremi" [The Harem of the Mufti], the emphasis is on envy between women and the isolation of the favourite, nameless wife of a wealthy potentate. The wife is surrounded by other women but still very lonely. Kallas hints at the possibility that the other wives would eventually poison her. She describes the wife as a victim and a prisoner, comparing her to a gold fish in a stone cold pond. Kallas, who was very aware of her own beauty, described the wife as a perfect "human work of art" ${ }^{25}$, beside whom all the western beauties paled. (1931, 55-66.) The remark is simultaneously an admiring confession and a condescending, objectifying act.

"Lalla Mulatin pidot" [The Banquet of Lalla Mulat] emphasises women's sociability and friendship, describing a banquet before Ramadan. Billie Melman has pointed out that the eyewitness descriptions of women's lives are full of details. From the mass of details emerge four main themes: the features and physiques of the women, costumes, eating and table-manners, and hygiene. The three first are also found in Kallas' texts. Melman emphasises that eating is the main way in which women interact. In harem literature food is socialised and women are mainly depicted as eaters. (Melman 1995, 99-126.) Kallas describes the meals and the participants in detail, revelling in the colourful richness of their clothes and adornments. She summarises the sight in a few words: "But in front of our eyes we have a whole flower bed from the garden of thousand and one nights. (...) But all of them, ugly and beautiful, young and old, shine brilliantly, like tulips, roses and carnations" ${ }^{26}$ (Kallas 1931, 48).

Kallas remarks that she was looking at a varied group of women who differed from the western ideal of female beauty. These women were exuberant and magnificent. In a fascinating way they combined sensuality and purity, and could be called "voluptuous Madonnas" (Kallas 1931, 49). ${ }^{27}$ It is notable that just before Kallas starts describing the women she reverses. She realises that she is also a participant in the viewing process and the dialect of gazes. She too is an object of gazes. She wonders how she and her Estonian companion appear in the Moroccan women's eyes: "What, for God's sake, is there worth looking at in these practical and rational black dresses" ${ }^{28}$, she sighs (Kallas 1931, 48).

So, the eastern women's otherness turns into a mirror of self-observation. Even clothes can be interpreted as signs of difference between the East and the West. It is obvious that Kallas thinks that eastern women represented a way of life that European women had just left behind. She returns to this question in her description of the Mufti's favourite wife. While mentioning that she has great respect for the achievements of western women, she sadly comments that simultaneously with the achieved equality the bloom of femininity seems to be vanishing. Can a whiff of envy be detected here, envy of colours and accessories? We may wonder if Kallas really thought that women's social equality would diminish their basic femininity. 
She confesses that she felt a kind of closeness with the eastern women but that in the end they still remained radically different:

This is simultaneously the culmination and the end of the banquet - unforgettable, mysterious and even melancholy. Now, in the twinkling dim light of coal fire and candles they gradually sink back into their own world, unavoidably. They are the East, we are the West - forever.

So far and so near, at the same time! There they sit, colourful and beautiful like flowers, like birds - and out of reach. One could as easily read the movements and secrets of their souls as one could those of golden pheasants or blossoming orchids. (Kallas 1931, 53-54.) ${ }^{29}$

Kallas was not satisfied with her own observations, but wanted to know more about Moroccan women. An English woman, Emily Keen, turned out to be a valuable resource. She had gained the respect of the locals through her marriage. Her life story was a turbulent love story in which a wild and independent Moroccan autocrat lost his heart to a golden haired woman and was tamed, at least for a while. Kallas questioned this 81 years old widow about the women's circumstances and future. She was informed that the change was slow in coming, but the women were quite satisfied with their lives at presently. There was no need to pity them. Kallas was also reminded that family lives were individual and could not be generalised. (Kallas 1931, 144-170.) She manages to convince her readers with this message. We should be very careful in judging other people's lives.

In Under the Spell of Morocco we find the question that reveals Kallas' own personal impressions of the journey. First she lists everything they have seen, but finally wonders if she really has seen all that with her own eyes or has everything only been a hashish dream? Was it a dream from which she had woken up to find herself back in the middle of the city, in the midst of dirt and fog?

\section{Aino Kallas' cosmic longing}

As a whole these Kallas' texts tell a story about a woman trying to find herself among her many roles and needs. In spite of all her travels it seems obvious that her wanderlust was not totally satisfied. In 1946, in the book Uusia kanssavaeltajia ja ohikulkijoita Kallas writes how limited and incomplete her experiences have been. She had not made all her dreams come true. She had not travelled around the world, not even been to India. As Maarit Leskelä-Kärki has pointed out, Kallas' longing crossed all borders. (Leskelä 1998, 160-168.) We might call it cosmic longing. Kallas, in her early diaries, called it Weltschmerz, which finally seeks relief beyond the stars.

On the other hand, Kallas also longed for the permanence of home. After returning from Morocco she wrote that she had a desperate need of a home. She did not have any place in sight, where she could raise the clay walls of her nomadic tent. As noted earlier, during her late years Kallas feared that she would end up in a reed cottage, forced to accept the role of an eternal 
wanderer (Kallas 1946, 220). The two opposite sides of her life gave her much but also exhausted her strength. She wanted to be a world citizen and yet also to belong somewhere. But, as she herself wrote, this moving between the opposites of travelling and staying in one place was nevertheless her truest self, the way to realise her inner being and essence.

\section{Notes}

1. [Koko elämäni kulku on ollut heilurin liikuntaa kahden tuiki vastakkaisen päätepisteen kanssa: lujan kotikiintymyksen ja kaukokaipuun, vastustamattoman vaellushalun. Olen vuoron perään kuullut kummankin kutsun ja totellut sitä kuin verenperinnän vaatimusta enkä pystyisi valalla vannomaan, kumpi niistä on toistaan väkevämpi. Molemmat ovat suoneet minulle elämän eri vaihekausina täyden ja syvän tyydytyksen, molempia totellessani olen tiennyt toteuttavani sisintä, ominta itseäni.]

2. [En tiedä minne kerran suuntautuu ihmisen ikävä, kun joskus joka paikka tätä avaruudessa kieppuvaa maapalloamme on tutkittu, mitattu ja kartoitettu, jokainen viidakko perattu, jokainen alkuasukassaatettu sivistyksen siunaukseen osalliseksi, ja valtamerensyvyydet luovuttaneet viimeisetkin salansa. Sinä hetkenä, jolloin Tuntematon lakkaa olemasta, käy maapallo meille ahtaaksi.]

3. [Miksi ihmiset matkustavat? Itseäänkö pakoon, muitako pakoon? ikuisen uteliaisuuden vaiko kyltymyksen kiirehtimänä? - löytääkseen itsensäkö vai löytääkseen Indrapoeran tulivuoren Sumatran saarelta?]

4. Elsa Enäjärvi-Haavio died of cancer in 1951, after finishing the preliminary research for the biography.

5. This article is based on my study of the Finnish female travellers, see Hapuli 2003.

6. [Lontoo! Olen taistellut jättiläisen kanssa, mutta voittanut. Se ei ole enää pahansuopa, suunnaton hirviö, vaan ystävällinen, suopea ja valmis kohottamaan minut kuten lukemattomat muut ennen minua.]

7. [Tällaiselta siis tuntuu olla kuuluisuuden ovella. Niin kuin olisi kihloissa tämän ihmeellisen Jättiläisen kanssa, jonka nimi on Lontoo.]

8. [On kysymys vain kahdesta: joko voitan minä Lontoon tai tappaa Lontoo minut.]

9. [Lontoolainen kuherruskuukausi - honeymoon - on lopussa.]

10. [Rakastan tätä laajuutta, hankauksen puutetta, niin, juuri sitä. Täällä on tilaa kasvaa joka suunnalle.]

11. [Ja nyt - yhä syvymmälle meren pohjaan vajonneina molemmat.]

12. The journey started on the 1st of April and ended on the 20th of April 1953.

13. [Mutta olen ollut aina valmis - lienenköhän sanonut tämän jo kerran ennen? - panemaan kirjan syrjään ja lukemaan ihmistä, kaikkien kirjojenkin alkusolua.]

14. [Kaikki Idän ihmeet, rakennustaiteen valtavat muistomerkit, menneen loiston rauniot, yhä kivettyneisyydessään säilyneet perintätavat, jotka sallivat katsella ikään kuin toiselta tähdeltä vuosituhansien takaista elämää, joka jo muualla on sammunut, monet kansalliset, uskonnolliset ja valtiolliset probleemat, - kaikki tämä käy sittenkin kalpeaksi ja toisarvoiseksi niitten ihmeitten rinnalla, mitä tarjoavat ihmiskohtalot näissä jo itsessään niin poikkeuksellisissa oloissa.]

15. [Mies, arka, pelokas kuin peto, joka minä hetkenä hyvänsä voi livahtaa maanalaiseen loukkoonsa. Mahdollisesti myös kuorieläin, nilviäinen, joka vain varovaisesti pistää esiin tuntosarvensa. Mies, joka ei hymyile, ei naura, ei puhu.]

16. About Kallas's political views see also Rauhala 2009. According to Rauhala, Kallas 
could be regarded as a representative of the liberal right-wing and absolutely as a pacifist.

17. [Lady Richmond Brown on muudan niistä monista anglosakseista, joka on kuullut Tuntemattoman kutsun ja seurannut sitä.]

18. It is astonishing that Tweedie's work was not translated into the Finnish until 1989.

19. [Kovin ottein on kohtalo kauhduttanut elämäni kerran kirkkaat värit. On joskus ikäänkuin pakoa kovasta todellisuudesta viivähtää muistoissaan vaikkapa vain hetkinen Buckinghamin palatsin kristallikruunujen alla.]

20. [slummitaudin itiö.]

21. [Tulen kuin toukka päivänvaloon litistävän laudan alta.]

22. [troopillisia ihmisolentoja.]

23. The Finnish historian Seppo Sivonen refers to Valerie Smith's introduction in the Host and Guest. The Anthropology of Tourism (Oxford: Oxford University Press, 1978) and names Kallas as a representative of ethnic tourism. The tourist is impressed by homes, villages and also by different cultural traditions. (Sivonen 2002, $1,38-61$.

24. Ghose draws on Jackie Stacey's theories on active female spectatorship in her book Star Gazing. Hollywood Cinema and Female Spectatorship (London: Routledge, 1994.)

25. [Muftin haaremin lempivaimo on täydellinen ihmistaideteos.]

26. [Meillä sen sijaan on silmäin edessä kokonainen kukkalava tuhat ja yhden yön yrttitarhasta. (..) Mutta kaikki, niin rumat kuin kauniit, niin nuoret kuin vanhat, loistavat koreina kuin tulppaanit, ruusut ja neilikat.]

27. [Heitä varten olisi luotava sana 'hekumallinen madonna', niin eroamattomasti yhtyvät heissä puhtaus ja aistillisuus.]

28. [Mitä, Luojan nimessä, on katselemista käytännöllisessä ja järkevässä kävelypuvussa $[--]$.

29. [Tämä on pitojen huippukohta ja loppu samalla kertaa - unohtumaton, salaperäinen ja yhtaikaa kuin alakuloinen. Nyt vasta, tässä hiilivalkean ja kynttilöiden lekuttavassa hämärässä he vajoavat lopullisesti takaisin omaan maailmaansa, auttamattomasti. He ovat Itää, me Länttä, - ikuisesti.

Lähellä ja etäällä, yhtaikaa! Tuossa he istuvat, kirjavina ja kauniina kuin kukat, kuin linnut, - ja yhtaikaa saavuttamattomissa. Yhtä hyvin taitaisi kysyä kultafasaanilta, tai orkidealta heidän sielunsa liikkeitä ja salaisuuksia!]

\section{References}

\section{Research objects}

Kallas, Aino 1928: Langatonta sähkö̈̈. Pieniä kirjeitä Lontoosta. [Wireless electricity. Brief Letters from London.] Helsinki: Otava.

Kallas, Aino 1931: Marokon lumoissa. Pieniä kirjeitä Marokosta. [Under the Spell of Morocco. Brief Letters from Morocco.] Helsinki: Otava.

Kallas, Aino 1944: Löytöretkillä Lontoossa. Kaksitoista vuotta Viron Lontoon-lähetystössä vuosina 1922-1934. Muistelmia Englannista, Amerikasta ja Hollannista. [Exploring London. Twelve Years in the Estonian Embassy in London. Memoirs 
from England, United States and Holland.] Helsinki: Otava.

Kallas, Aino 1946: Uusia kanssavaeltajia ja ohikulkijoita. Muistoja ja muotokuvia. [New Travelling Companions and Passers-By.] Helsinki: Otava.

Kallas, Aino 1947: Kolmas saattue kanssavaeltajia ja ohikulkijoita. Muistoja ja muotokuvia. [Third Group of Travelling Companions and Passers-By.] Helsinki: Otava.

Kallas, Aino 1953: Päiväkirja vuosilta 1907-1921. [Diary from the Years 1907-1921.] Helsinki: Otava.

Kallas, Aino 1955: Päiväkirja vuosilta 1922-1926. [Diary from the Years 1922-1926.] Helsinki: Otava.

Kallas, Aino 1956: Päiväkirja vuosilta 1927-1931. [Diary from the Years 1927-1931.] Helsinki: Otava.

Kallas, Aino 1957: Vaeltava vieraskirja vuosilta 1946-1956. [Wandering Guest Book from the Years 1946-1956.] Helsinki: Otava.

\section{Research literature}

Bassnett, Susan 2002: Travel writing and gender. In Peter Hulme and Tim Youngs (eds.), The Cambridge Companion to Travel Writing. Cambridge: Cambridge University Press.

Behdad, Ali 1999: Belated travelers. Orientalism in the Age of Colonial Dissolution. (2. pr.). Durham and London: Duke University Press.

Ghose, Indira 1998: Women Travellers in Colonial India. The Power of the Female Gaze. Oxford: Oxford University Press.

Hapuli, Ritva 2003: Ulkomailla. Maailmansotien välinen maailma suomalaisnaisten silmin. [Abroad. Finnish Women Travelling Between the Two World Wars.] Suomen Kirjallisuuden Seuran Toimituksia 911. Helsinki: Suomalaisen Kirjallisuuden Seura.

Laitinen, Kai 1978: Aino Kallaksen maailmaa. Kuusi tutkielmaa Aino Kallaksen vaiheilta. [The World of Aino Kallas. Six Essays on Aino Kallas' Life.] Helsinki: Otava.

Lawrence, Karen 1994: Penelope Voyages. Women and Travel in the British Literary Tradition. Ithaca \& London: Cornell University Press.

Leskelä, Maarit 1998: Päiväkirjojen Aino Kallas. Naissubjekti modernin murroksessa. [Aino Kallas in her Diaries. The Female Subject at the Turn of Modernity.] Kulttuurihistoria, Turun yliopisto. (Unpublished thesis for FL)

Leskelä-Kärki, Maarit 2006: Kirjoittaen maailmassa. Krohnin sisaret ja kirjallinen elä$m \ddot{a}$. [The Krohn Sisters: Lives in Writing.] Suomen Kirjallisuuden Seuran Toimituksia 1085. Helsinki: Suomalaisen Kirjallisuuden Seura.

Lewis, Reina 1996: Gendering Orientalism. Race, Femininity and Representation. London \& New York: Routledge.

Löytty, Olli 2006: Ambomaamme. Suomalaisen lähetyskirjallisuuden me ja muut. [Our Ambomaa. We and the Others in Finnish Missionary Literature.] Tampere: Vastapaino.

Melberg, Arne 2006: Resa och skriva. En guide till den moderna reselitteraturen. [Travelling and Writing. A Guide to the Modern Travel Literature.] Göteborg: Daidalos.

Melman, Billie 1995: Women's Orients. English Women and the Middle East, 1718-1918. Sexuality, Religion and Work. (2nd ed.). Houndsmill \& London: Macmillan.

Rauhala, Pirkko-Liisa 2009: Elämä ja politiikka Aino Kallaksen päiväkirjassa 18971931. [Life and Politics in the Diary of Aino Kallas, 1897-1931.] In: Maarit Leskelä-Kärki, Kukku Melkas, Ritva Hapuli (eds), Aino Kallas. Tulkintoja elämästä ja tuotannosta. [Aino Kallas. Interpretations of her Work and Life.] Helsinki: BTJ. 
Sivonen, Seppo 2002: Afrika kallar. De findlänska Afrikaresenärernas motiv och reseintryck före massturismens tid. [Africa is Calling. Motives and Impressions of Finnish African Travellers Before the Age of Mass Tourism.] Historisk tidskrift för Finland 1.

Stallybrass, Peter \& White, Allon 1986: The Politics and Poetics of Transgression. London: Methuen.

Yeğenoğlu, Meyda 1998: Colonial fantasies. Towards a feminist reading of Orientalism. Cambridge: Cambridge University Press. 


\title{
Songs of Comfort and Lamentation
}

\author{
Autobiographical Connections in the Texts \\ of the Ageing Aino Kallas
}

One particular topic in the texts of Aino Kallas is the notion of the connection between the lived and the written account of it. This notion seems to be at the core in her view of her own identity as a writer. She herself analysed this connection in her memoirs in a short autobiographical sketch titled "Eräs kanssavaeltaja" [A certain fellow traveller]:

It seems clear to me, that the most objective writer and artist always draws from her own experiences, from the well of her own views. She can, as in masquerade, veil herself in the rags of a beggar or in a purple cape, with the help of her imagination she can wander through vast, dangerous and dazzling destinies like in her dreams, but the core cell remains the same, it is rooted in herself. (Kallas 1945a, 248. $)^{1}$

In this analysis of an artist, Kallas saw that whatever roles and identities had to be taken during the process of writing, the core of writing was within the writer herself, in his or her personality and experiences - despite what kind of literature he or she wrote. At the end of this self-portrait she connects herself and her writing to the main character of Aalo in her most famous novel Sudenmorsian [The Wolf's Bride] (1928). She writes that Aalo describes “... in the most perfect way her deepest, most hidden self, which yet aspires to be exposed again and again throughout a creative process." ${ }^{2}$ According to Aino Kallas, her double-sided soul was shaped in the character of Aalo, who “... hovers between two opposite powers, as she yearns for the company of the wolves and to the enchantment of the Diabolus Sylvarum [the spirit of the forest], and, yet, in spite of the threat of being killed, returns to her children and her husband from her odyssey." (Kallas 1945a, 249.)

In this autobiographical portrait, as in many other writings, Aino Kallas portrayed herself as an author, who had to live the life of an artist. She was very conscious of her identity as a writer, and the aim of becoming an acclaimed author can be traced already from her early diaries, written when she was 18-20 years old (Makkonen 1999). She thought that a fully lived life was the ground for creative work and art. This viewpoint was strengthened 
in 1908 when she, in her thirties, experienced a crisis in her literary work; she wanted to turn her gaze from the outer world to the inner life. ${ }^{4}$ She wrote in her diaries and in her letters to her colleagues, how her "rich inner life" demanded that she would not anymore write any lines, which would not be lived in some sense. Yet, she departed herself from the tradition of "confession writing", and saw that she had a long journey ahead until she could write from a distance, so, that the inner experiences would be objective enough (see Kallas' diary 19.12.1908, 1953, 121-122).

Kallas herself used the term 'confession literature', with which she seems to have referred to the tradition of autobiographical literature that has its roots in the Confessions of St. Augustine (written in 397-401). ${ }^{5}$ It seems that Aino Kallas very strongly defended the close connection between the lived and the written, but nevertheless wanted to distance herself from autobiographical writing as such. From her point of view, confession meant a very straightforward connection to the life of the author, or confessing the secrets of one's life in fiction. From 1908 onwards Kallas' production showed more symbolistic and impressionistic tones, but as Kukku Melkas (2006 and 2007) has pointed out, her production continued to deal with social topics such as power relations between the genders and production of knowledge, also in her famous novels of the 1920s, although they have earlier (see e.g., Laitinen 1995b) been interpreted more or less as stories of forbidden love.

Against these interpretations it is even more interesting to notice the many autobiographical connections that are being constructed in Kallas' writings throughout her life. My aim in this article is not to interpret the fictional writings of Aino Kallas as reflections of her own life and her experiences, but I am interested in this connection she herself so powerfully proclaimed. My viewpoint derives from the notion, that the borders of "fictional" texts and "autobiographical" accounts are complex and shifting. No text is fully fictional or fully autobiographical. Every kind of text uses various textual ways of plotting, conventions etc. We should analyse different kinds of texts as more related to each other, and, as Liz Stanley argues, see how the supposed binaries of self and other, fact and fiction, past and present, reality and representation, autobiography and biography overlap and intersect in different narratives. (Stanley 1992, 59-88; Tuohela 2008, 42-45; Leskelä-Kärki 2008. $)^{6}$

The overlapping of genres is a particularly important notion in the case of an author such as Aino Kallas. She did not write an autobiography of herself during her lifetime, but produced various kinds of texts, which could be called autobiographical. She published both memoirs and diaries before she died. The memoirs written during the 1940s, and partly already before, consist of short sketches of various people, places and events during her life - they do not form an autobiography with a linear story of a life lived, but offer glimpses of her life and, what is even more important, her surroundings. An important part of these three-volume memoirs are the travel writings she actively produced in the 1920s and after (see Hapuli 2003 and in this book). The diaries from the years 1897-1931 were published during the 1950 s at the publisher's request, but Kallas herself edited those and was very conscious of the process of publishing her intimate texts. 
In her memoirs and diaries she often makes remarks on her fiction and refers to the autobiographical connections in them. This happened also in the interviews made by literary critic, folklorist Elsa Enäjärvi-Haavio and literary historian Kai Laitinen during the 1940s and 1950s. ${ }^{7}$ Quite straightforwardly Kallas related some characters to real persons saying for example, how the priest of Reigi was her husband Oskar Kallas, or how the Spirit of the Forest (Diabolus Sylvarum) in Wolf's Bride was the poet Eino Leino, with whom she experienced a love affair in the late 1910s (Laitinen 1995b, 321-322). Kallas also wrote biographies, one on the Estonian national poet Lydia Koidula (Tähdenlento, [The Shooting Star] (1915)) and another one on Oskar Kallas (Elämäntoveri [Companion for Life] (1957)) - a work that remained unfinished and was published after her death by her niece as an edited book.

As a genre autobiographical texts are always under negotiation. Research done in the late $20^{\text {th }}$ century concerning autobiographical writing has made important connections between autobiography and the concept of truthfulness. Philippe Lejeune has launched the term autobiographical pact (le pacte autobiographique), which refers to an agreement between the writer and the reader of the text, where the author promises the reader to tell his or her whole life-story or parts of it. The pact consists of an idea that the story to be told will be truthful, at least from the viewpoint of the author. ${ }^{8}$ Swedish literary historian Lisbeth Larsson points out that all autobiographical writings (diaries, letters, autobiographies, biographies, memoirs) are constructions and thus also stories. She also refers to a special truth pact the author makes with the reader thus rendering the texts "true accounts" regardless of whether their content can be proven to be true or not. (Larsson 2001, 16).

Kallas' texts relate to the idea of truthfulness in various ways as they imply a conscious construction of her literary identity in different textual forms, for example in her diaries. As Lynn Z. Bloom argues, no professional writer has intimate texts as such - he or she is always faced towards the readers, and aims at telling a story (Bloom 1996; see also Makkonen 1999). Thus, the textual spaces of fiction and autobiography overlap in a very concrete way. The autobiographical references increase in the different texts of Aino Kallas, as she gets older. During the 1940s and 1950s writing and its meanings to her self-identity crystallise in a new way. I shall now look more closely at her different texts from this period, and analyse the ways she connects her life-story and her writing. I shall also consider the many (often autobiographical) meanings she gives to the actual act of writing.

\section{Poetry during wartime}

Old age has not been a popular topic when discussing authors, especially female authors, although many writers keep up with writing until their death, or might produce their masterpieces, when past the usual age of retirement. ${ }^{9}$ Aino Kallas has been portrayed as a powerful, beautiful talent in the prime of her life. Age has not been an issue when talking about her, not at least after her literary debut that happened when she was, at the age of 19 the young- 
est female debutante in the Finnish literary field so far. Her late production from the 1940s and 1950s has not been the main interest of Kallas' researchers, maybe because it does not connect to questions of modernity as does her production from the 1920s.

The latter part of her life, particularly from the beginning of the 1940s onwards, highlights her literary identity from the autobiographical viewpoint. If we look at her last fifteen years from the point of view of the practice of writing, we can see a writer, who is almost compelled to write and produce texts. She published several collections of poems and memoirs, started to write the biography of her deceased husband Oskar Kallas as well as edited her diaries, and corresponded constantly with her closest relatives and friends. She also continued her work on Estonian ballads and legends, and published three collections of short stories. In her letters and diaries she constructed writing as a necessary means of survival, simultaneously the meanings of writing gain new dimensions and the autobiographical connections become more visible than before.

As in any writer's case, Kallas' literary work and identity as a writer was formed as part of the historical and cultural context of her times. Important background for Kallas' writing and her literary work during the 1940s can be found in the tragic changes in the family's life. Both the topics of her writing and, even more so, her compulsion to write in the 1940s and 1950s were based in the wartime and her own experiences during those years.

Kallas had been severely ill from early 1939 onwards, and she was practically lying in bed for 14 moths after an infection in her heart. In 19401942 the whole family stayed in Estonia, except for the youngest boy Hillar who lived in England. They faced the Soviet occupation and the horrors of deportations. A notebook from Kallas remains, where she has written the names of their closest relatives and friends who were deported to Siberia. The total number reached 300. (Laitinen 1995b, 379.) Kallas' son Sulev Kallas was interrogated, and under pressure he committed suicide in early 1941. In August of the same year, Kallas' younger daughter Laine was shot accidentally by a Russian soldier. It was not until the end of 1942, that Kallas was able to visit Helsinki, and she stayed there until the next summer. In October 1943 she left Estonia, and never returned. Her husband Oskar Kallas and their daughter Virve with her children were able to follow Aino Kallas to Finland only in March 1944. In October 1944 they escaped to Stockholm via Turku. The long years of exile were ahead. Oskar Kallas was already severely ill and died in January 1946. The whole core of Aino Kallas' life changed in a few years time. She remained living at the same address in Stockholm until 1953, when she was finally able to return to Finland officially, after regaining her citizenship that she had lost over 50 years ago due to her marriage.

During the most turbulent years, 1942-1945, Kallas published three collections of poems, which she had not done since 1915. As Kai Laitinen (1995b, 384) notes, Kallas wrote most of her poems at times of crisis in her life. After the first published collection of poems in her youth in 1897, she published a collection Suljettu puutarha [Enclosed garden] in 1915, when she was in the middle of a literary and personal crisis, looking for a 
new direction for her writing (see also Aune Krohn's letter to Aino Kallas 18.5.1947, FLS LitA). Subsequent poems were not published until these three collections during the 1940s. Poems were not a continuous literary work for Kallas, but, rather, an intensive speech, outburst at times of crisis. This becomes evident when reading the poems from the collections Kuoleman joutsen [Swan of Death] (1942), Kuun silta [Moon Bridge] (1943) and Polttoroviolla [At the Funeral Pyre] (1945). They reflect the atmosphere of war from an individual perspective, occasionally almost in a documentary way: the topics range from the deaths of her children to ageing, being a refugee and the insanity of war. ${ }^{10}$

In The Swan of Death she, for example, remembers the death of her children in an almost macabre poem called "Taivaallinen rekiretki" [Sleigh Ride in Heaven]. She uses the rhyme typical of children's poetry "hopoti hopoti hoi" ${ }^{11}$ from a poem by her own father, Julius Krohn from the 1860s as she imagines her three ${ }^{12}$ dead children riding in a sleigh among the sun and the moon watched by the angels and god. Occasionally, she also refers to her own mortality, but death is most vividly, and devastatingly, described in the poems, where she refers to the deaths of her children. Like in the poem "Varjo" [The Shadow], where she, in the end, sees only "mould, mould/only eyes shut,/mouth forever silent"13 (Kallas 1942, 146).

Kallas also reflects on her position in exile, away from both homelands, aged and surrounded by destruction in poems such as "Maanpakolaisen hauta" [Grave of an exile], "Ihmiskunnan inhuus" [Abomination of humankind] or "Verinen kuu" [Bloody moon]. Her deep pacifism gained attention also among the Finnish critics; for example, Lauri Viljanen saw her sharp pacifism as exceptional in the field Finnish literature at that time (cit. Laitinen 1995b, 394). Loneliness and analyses of her self-identity and position in the world are part of the topics as in the poem "Myrskyn sydän" [The heart of the storm], where nature and herself are vividly seen as part of each other, as in so many other works of Kallas (see Melkas 2006 and her article in this volume). The "I" in the poem escapes to an island in the sea, as in the heart of a storm, and describes how she rests among the sheep, and vanishes to a grey stone. The sun bleaches her to driftwood, and the poet writes: "... my worries escape, like a shoal of fish in the low water" (Kallas 1942, 130). ${ }^{14}$

When The Swan of Death was published Kallas wrote to her sister Aune Krohn, that she would find there what she already knew: “... I have been living in 'The land of the shadows of the death' for almost two years now" (Aino Kallas' letter to Aune Krohn 21.12.1942, FLS LitA ). ${ }^{15}$ Some of the poems date back to earlier years in the 1930s, but in an interview with her biographer to-be Elsa Enäjärvi-Haavio Kallas pointed out, that she wrote tens and tens of poems during the early years of the 1940s. ${ }^{16}$

The autobiographical connections of the poems were also visible on the book covers; for example on the cover text to Moon Bridge it is stated: "The muse of Aino Kallas can never be that of a carefree and light-hearted muse, since the time behind her poems is full of distress and grief, without a single day of joy". ${ }^{17}$ It is pointed out how Kallas' poetry is not without consolation or courage, but it awaits proudly and calmly the moment of liberating atone- 
ment. ${ }^{18}$ (Kallas 1943, cover text.) The text does not merely refer to Kallas' own experiences, but also to the wider context of wartime, where feelings of sorrow and mourning could be collectively shared.

\section{The meanings of writing and mourning in Kallas' letters}

As a writer, Aino Kallas escaped to her work as can be read from the remains of her diaries and letters during those years. The life lived and her writing were connected in a totally new way, as a force, which at last gained enough room in her life, and made it possible to devote herself to writing. In her letter to Elsa Enäjärvi-Haavio, she wrote:

I work like a person, who knows her remaining time is limited. Everything else must be kept away, - the demand of work is even more unquestionable than before. Work has at last, in this late phase of life, taken me indivisibly. This kind of speed is dangerous and it prefigures the end, - it is also clear to me.... But I am already outside everything, I feel it. (Aino Kallas' letter to Elsa Enäjärvi-Haavio 14.5.1948, cit. Eskola 2003, 435. ${ }^{19}$

Work becomes compulsive, and mourning an inseparable part of it. Writing and especially poetry offered a way of handling and managing her bereavement. In a letter to Aune Krohn, she added, that it would be: "... difficult to try and live the everyday life without the comfort of a song" (Aino Kallas' letter to Aune Krohn 14.12.1944, FLS LitA). ${ }^{20}$ In her letters she constructed her identity as related to writing and mourning, in an almost obsessive way. Other parts of her identity became more and more unstable as her closest ones died, and her whole social and cultural context changed. Writing offered a means to construct a whole identity.

Letter writing was an important part of Aino Kallas' life from early childhood as it was for most of the educated class during the late $19^{\text {th }}$ and early $20^{\text {th }}$ century. Kallas' remaining archives cover correspondence to her relatives, friends, colleagues, and other professionals from nearly seven decades. Some of the material has gone missing, but there are around 1500 letters from Aino Kallas to her sisters Helmi and Aune Krohn. The numbers are not any smaller in the case of letters to her husband, children and other close relatives. Correspondence was a means to stay in touch, to tell about the everyday events and to organise practical things, but it was also about bonding with the closest ones, constructing relationships, and constituting one's self-identity. ${ }^{21}$

It is, however, notable that for Aino Kallas letters did not take the place of mourning and handling the losses and tragedies. The correspondence during the 1940s for example with her sisters Aune and Helmi Krohn are nearly totally devoid of the notions about the deaths, the losses and the grief. It is merely in between the lines. It seems, that the grief was written in different forms and in different documents than one might assume. Poetry offered a genre to handle the losses; it offered a literary space to overcome the experiences. 
Instead of pouring her grief in the letters, Aino Kallas constantly referred to the meanings and practices of writing in her life in her letters, especially to her sister Aune Krohn and her close friend Anna-Maria Tallgren. These correspondences also reveal new perspectives on the personality of Aino Kallas. Instead of the somewhat canonised picture of the self-centred, creative person, who yearns to become a praised author, and reflects other parts and roles in her life only against the identity of a writer, these letters reveal a more "downto-earth" Kallas, who reflects herself in a dialogue with other women.

Aune Krohn, also a writer and translator, found similarities between the sisters in that they both loved "a short poem", and yearned for poetry (Aune Krohn's letter to Aino Kallas 6.7.1952, FLS LitA). The sisters shared the need to pour the difficulties and tragic events to work. Aune Krohn used words such as "outlet" [laskuoja] and "demolition channel" [purku-uoma], which refer to writing as an aid to unload one's emotional burden. The notion of the therapeutic elements of work and the almost compulsive admiration of work connected the epistolary sisters. Aino Kallas referred in her letters again and again to the compulsion of creativity, which helped her to cope:

I have sweated and proofread the pages for my new book, and tomorrow I will send it to the press. But the old Estonian folk poem is correct: laulu laulisteist murehi! $!^{22}$ As soon as you get rid of one, another one is already at the door, lasting satisfaction is never possible. My compulsion to create has been like a fever from 1942 onwards, and still I don't feel any alleviation. Poems, memoirs, just recently prose legends. Poems for the collection At the Funeral Pyre are also now in press and will be out this Autumn. (Aino Kallas' letter to Aune Krohn 16.9.1945, FLS LitA.) ${ }^{23}$

Work becomes her sole "comfort and joy" as well as "everyday medicine" in her lonely daily life. (Aino Kallas' letter to Aune Krohn 11.3.1945 and 28.10.1945, FLS LitA.)

Aune Krohn remained one of the most important persons, with whom Kallas corresponded until her own death in 1956. The letters were important in strengthening the self-identity and maintaining the family roots while in exile with only a few family members around her. In 2007 the picture of Kallas' social network was enlarged when the letters between her and AnnaMaria Tallgren, a critic, journalist and writer, were found in the archives of Kallas' publisher Otava. The women had become acquainted in 1919 in Copenhagen at the International Congress for Writers, and their friendship remained close and strong until Tallgren's death in 1949. These letters were published in 2008 in an edited collection by Silja Vuorikuru, and they renew the picture of Aino Kallas. Aino Kallas shared her thoughts about the meanings of writing also with Tallgren, although the letters are fewer than to Aune Krohn. In these letters writing also has very practical dimensions, for example when she writes of the connection between writing and needlework:

I suffer from the darkness of Autumn as always - this time even more. I fight against it with every possible means, and the most effective is work. During the 
last couple of weeks I have written legends and chronicles in prose, they will be connected with each other by The Tale of the Seven Virgins. My new fellow travellers will soon reach you, I asked the publisher Otava to send them to you. - I also knit gloves and wool shawls, it is calming and does not tire your eyes - wasn't there already les tricotoeuses who knitted, while heads were falling? (Aino Kallas' letter to Anna-Maria Tallgren 10.10.1946, 301, in Vuorikuru [ed.] 2008. $)^{24}$

Kallas made an interesting connection, when she compared her situation to that of the women, who sat beside the guillotine knitting and counting the executions that were done during the Reign of Terror after the French Revolution. Kallas compared that to her own position as a refugee, who was surrounded by the aftermath of a terrible wartime and by the deaths of her closest ones. Knitting and writing offered a peaceful, enjoyable work, which helped to cope with the worries and difficulties.

\section{Wandering sorrows}

The previously important form of diary became a necessary tool as well. The last diary of Aino Kallas was started in 1946 as a guest book where Kallas' friends would write a few lines after visiting her in Stockholm. Very soon it changed into writing a personal diary although the lines of the visitors remained in the book. This notebook was not published until after Kallas' death by her niece Annikki Setälä, and it covers the last ten years of her life 1946-1956. It was then entitled Vaeltava vieraskirja [Wandering Guest Book]. This volume offers a valuable glimpse of the last decade of Aino Kallas. ${ }^{25}$ In the texts she contemplates her work and her remaining family members, remembers the lost ones, and ponders her difficult situation in Stockholm as she yearns to return to her home country Finland.

Wandering Guest Book develops into a touching document of an ageing woman writer, and it often solidifies the connection between writing and mourning. In these diary notes Kallas continuously marked the days of birth and death of her children, and remembered the tragic moments over and over again. On August $16^{\text {th }}, 1950$, she remembered the day her daughter Laine had been killed, and noticed, how the writing of a new short story had helped her in her mourning: "Although I have managed to write only eight lines, already the restless, gripping pain has eased" (Kallas 16.8.1950, $1957,51) .^{26}$

Anxiety caused Kallas to write even more intensively. She remembered when:

... there was a time - after the deaths of Sulev and Laine - when pain and grief were so hard that they had to burst into poetry, otherwise I would have suffocated. My present, continuous diary writing, which often happens at nighttime, is related to those. (Kallas 26.7.1953, 1957, 303.) ${ }^{27}$

Her poems from the first half of the 1940s can be interpreted as an artistic way of escaping sorrow, of dealing with pain and the deepest anxieties. It is 
interesting that later Kallas reflected on writing poems and diary as similar activities. Since the Wandering Guest Book begins in 1946, and the diaries after 1931 have disappeared, we do not know for sure whether Kallas even wrote diaries at the early 1940s. From this extract it is possible to conclude, that poems were the main method of writing at the time of deepest sorrow. ${ }^{28}$ Her letter to Anna-Maria Tallgren also confirms this: “... I have moved in the field of pure lyrics when inner pain and grief have been too heavy a burden to carry, and it has been easier when it has gotten a form. That is the birth story of my three latest collections of poetry." (Aino Kallas' letter to Anna-Maria Tallgren 29.9.1947, in Vuorikuru [ed.] 2008. ${ }^{29}$

Just as Kallas could not (or choose not to) write about her sorrow in her letters, she perhaps could not write a diary at the time of the actual losses in the early 1940s. As a more artistic genre poems may have offered a more distanced way of handling the deepest feelings; this is evident when Kallas points out the importance of form in the citation above. Finnish sociologist Tuija Saresma (2000), who has analysed autobiographical writing, has pointed out that people can reject dealing with losses in personal writings at least at the time when the actual tragedies happen although writing in general can be regarded as an important method of coping. This could have been the case with Aino Kallas as well: she could not dwell on her losses in her most personal writings. Only later did she return to the tragic events by regularly remembering them in her diary - at that time already five years had passed since the deaths of her children. Wandering Guest Book could thus be viewed as a book of remembrance and recollection - beside it Kallas also started to write the biography of Oskar Kallas, which was also about remembrance.

The above-mentioned autobiographical sources, letters and the diary, tell about a constant dialogue between work and mourning. The textual webs between her poetry, fiction, letters and diaries reveal a continuous, and at times, very conscious construction of literary identity, which overlaps her personal identity in ways that escape strict genre definitions.

\section{"Out of my grief I carved a singing tree for bird, for the joy of the morning sun and the evening moon." ${ }^{\circ}$}

For Aino Kallas in many ways writing was a way to mourn. On the one hand, it offered a place to escape from the daily mourning, and on the other hand, a space to deal with the losses, to write about her grief. Continuous working, production of memoirs and fiction offered a means to escape from distressing thoughts, and she found consolation and relief from work. At the same time she used her experiences as a source for creative work, and poetry and the diary were places where she concretely remembered, grieved and cried. In the poem "Bird of poetry" [Runon lintu] she speaks to the bird of poetry, and claims that there is no other comforter than this bird, who is able to listen to her grief and weeping (Kallas 1943, 9). The motif of the bird is important and varied in her poems. A bird can be an inspiration for creativity, or a bird of sorrow, or a carrier of grief. ${ }^{31}$ 
The ability to be creative, to write and to publish offered Aino Kallas a liberated space and it also gave meaning to the losses she experienced. Tuija Saresma (2007, 151-199) has also written about the healing power of writing, when dealing with death, and feelings of anxiety and sorrow. Writing can become a liberating, therapeutic strength in the midst of sorrow. Writing is then also about remembrance, and a means to keep up with meanings and ties with the lost ones. Saresma does not want to emphasise the positive, healing power of death and mourning as such, but rather wants to locate the different ways people try to handle losses, and maybe also find new meanings to them. In Aino Kallas' case, writing in relation to her own experiences as well as using autobiographical genres such as memoir, diary, and biography gained more room in her literary practice during the 1940s. Her literary practice became much more diverse as she also enthusiastically continued more fictional writing and still used historical sources in her collections of short stories, which were based on old ballads and legends and other historical material.

The question of personal and/or autobiographical writing is, of course, rather different in the case of Aino Kallas than for example in the case of those women Saresma writes about in her research on autobiographical writing. Saresma uses mostly texts of "ordinary" people, who participated in different kinds of collections organised by the Finnish Literature Society's Folklore Archives. These people did not aim at publishing their writings or acting as writers as such. Comparing to those, Kallas was an established, canonised writer, who wrote and formed her literary identity against publicity. For Aino Kallas writing was an essential part of her self-identity; she had written all her life and was born in to a literary family, where writing and acting in the society were regarded as obvious and important tasks, also for women. (See more in Leskelä-Kärki 2006.) The last decades of her life, the 1940s and 1950s open up the importance of writing in a totally new way, since grief, losses and mourning became such an essential part of her literary work. Simultaneously she wrote more than ever before about the meaning of writing in her letters, diary, poems and memoirs. Thus, one can regard this as an exceptional phase in her life.

Kallas' poetry and the process of mourning through writing can also be compared to Finnish lyrical folklore, where the central topic is the work of mourning, as Senni Timonen (2004, 307-308 and 350-354) argues. The most common version is the plaint [valitus], which is strongly expressed in the so-called songs of sorrows [huolilaulu] as well as in lamentations [itkuvirsi]. Timonen has found in the poems the verb "winnow" [tuultaa], which refers to an active position of the subject, to an activity, where worries are carried out. ${ }^{32}$ Singing the "songs of worries" is simultaneously about winnowing out the agony and distress [tuskien tuultamista], thus it is a way to banish sorrows, or at least a way to begin to ponder them.

Thus, the tradition of folklore seems to possess a similar idea of an "outlet" [laskuoja] to which Kallas and her sister Aune Krohn referred. Winnowing has the idea of intersubjectivity in it, since singing the songs of sorrow is collective. Writing does not necessarily have a similar kind of idea of collectivity, since all of the texts might not be meant for the public (for example, a 
diary). Nevertheless, writing for oneself can also be intersubjective in a way; it is about producing one's thoughts over and over again, maybe also to an imaginary self in the future. "Winnowing out" the worries is about talking to someone in a similar way as writing a poem, letter or an entry to diary. When worries are somewhere out there, you can ponder them together and remove the worst agony from them. From this perspective Timonen points out, how all the songs of sorrow are, even in their darkest mood, a movement away from the sorrows, an active detachment from oppressive worries. (Timonen 2004, 350-354.)

In relation to Timonen's comments, we can note that in the collection Moon Bridge Kallas also used the rhythm of lamentation [itkuvirsi] in mourning her children and visualising their lives in the everafter (see also Laitinen 1995b, 390). In the poem "Itku" [A lament] she speaks tenderly to her children: ${ }^{33}$

When we meet again in the bright lit starry realms, will you know your mamma, your bearer, your poor birthmother?

Not an hour have I not wept for you, my sweet beloved, not a moment have I not mourned my brown-eyed, dark-haired darling. I cry for your golden heart, long bitter sweetly for your joyful tenderness.

You took to unknown roads before your mother, to travel strange paths in a silent land.

Or do you live there, in the lands of the blessed?

Glide as a white swan on the river of dreams?

Do you yearn for the pleasures of people?

Do you still remember the one who mourns for you, blissful as you are, beyond pain and trouble? ${ }^{34}$

There is also a short poem called "Itkuvirsi" [Lamentation] in the collection. It must be remembered that Kallas was very much aware of the tradition in which she wrote her poems as she was also when writing her prose ballads. Her writing was professional throughout her life, as she collected material for her works from archives and libraries. She could also use the knowledge of folklore of her husband Oskar Kallas and her brother Kaarle Krohn in searching for background material for her novels and short stories. The same professionalism can be seen in her work as a poet.

In the end, Kallas' poetry reflects the meaning of creativity in the midst of mourning. In her three collections of poems she comes to a certain conclusion, where personal losses are also a source for creativity. What remains, is the joy of working and creation as is evident in the poem, where she carves a singing tree for a bird from her grief. She assures this also in a letter to Anna-Maria Tallgren: "I still love sitting in the sun, children playing and, above all, the compulsive, often painful, but yet joyful feeling of artistic creativity" (Aino Kallas' letter to Anna-Maria Tallgren 12.8.1948, 309, in Vuorikuru [ed.] 2008). ${ }^{35}$

The autobiographical references that Aino Kallas constantly and throughout her life made form an integral part of her identity as a writer. These 
references reflect the ways she constructed herself as an author and the formation of her literary identity. It is, though, important to note that literary identities are not fixed and permanent as no identities are. They change and vary throughout one's life. The ageing Aino Kallas wrote her literary identity in her diary entries in a different manner than the young, ambitious writer, who had only started to construct her literary identity.

What is overlapping in these literary identities of different ages are the connections between the lived and the written that are expressed in Kallas' various documentary and more fictional texts. She wrote her poems in the context of war and personal tragedies - in her most personal poems, as well as in her letters and diary entries, she is strongly attached to the historical moment in which she writes. This imaginary horizon of a certain historical time (Kosonen 2004, 9-10) defined what she as an author was able and forced to imagine and also that which she could not imagine. Thus, her texts can also be viewed from a more general view point, as reflections of a woman, who through her most personal experiences also wrote about war, violence and historical changes.

\section{Notes}

1. [Selviö lienee, että näköjään kaikkein objektiivisinkin kirjailija ja taiteilija aina kuitenkin ammentaa omien kokemuksiensa, omien näkemyksiensä säiliöstä. Hän voi, kuten naamiaishuveissa on tapana, verhoutua mielensä mukaan joko kerjäläisen ryysyihin tai purppuravaippaan, hän voi toiveuniensa mukaisesti mielikuvituksensa siivittämänä vaeltaa halki huimaavien, vaarallisten ja häikäisevien kohtaloiden, mutta alkusolu on kuitenkin aina sama, se piilee hänessä itsessään.] All the original diary, letter and poem extracts are translated by the author, except for the poem "Itku", that was translated by Dr. Phil Kalle Pihlainen. I also want to thank the research group "Gender, writing and textuality" at the Department of Cultural History for their insightful comments (Kirsi Tuohela, Ilana Aalto, Annikka Konola, Reija Lång, Anna-Leena Perämäki).

2. [ ... kuvastuu parhaiten sisin, visuimmin salattu ja aina kuitenkin yhä uudelleen ilmaisuun pyrkivä itseni.]

3. [... vaappuu kahden vastakkaisen voiman välillä, ikävöi sutten seuraan ja Metsien Hengen ... lumoihin ja kuitenkin kuoleman uhallakin palaa harharetkiltänsä lapsensa ja miehensä luo.]

4. Kallas had started her literary career with a collection of poems in 1897, after that she published a collection of short stories (1899) and her first novel Kirsti in 1902. After moving to Tartu, Estonia in 1903 she started to use Estonian history, myths, ballads and legends as the source material for her literary work. Two collections of short stories Meren takaa I and II [From beoynd the Sea I and II] were published in 1904 and 1905, and in 1907 a novel Ants Raudjalg. Many of her texts from this era tell the stories of the repressed bondsmen of Estonia under the rule of the German upper-class and Russian government. See more in Laitinen (1973) 1995a, 45-100.

5. Confessions [Confessiones] is generally seen as the (pre)historical starting point for the development of modern autobiographical writing. Traditionally the heyday of this genre has been situated in the $18^{\text {th }}$ century and onwards. There is, however, a rich and various tradition of autobiographical writing already from the early 
Antiquity onwards. In this context Confessions can be seen as an outcome of this long tradition. The autobiography is thus not a genuinely modern, $18^{\text {th }}$-century phenomenon. (Kosonen 2007, 14-25, 132-141.)

6. Liz Stanley uses the term 'auto/biography' referring to this intersectionality (Stanley 1992).

7. The process of writing Aino Kallas' biography is an interesting one since Elsa Enäjärvi-Haavio was the first one to plan a biography on Kallas. She knew the writer, and they were quite close friends. The project ended, however, when EnäjärviHaavio died in 1951. She had already made extensive interviews with the writer, and the notes were handed out to a young literary student Kai Laitinen, who continued the work during the 1950s. The first part of Laitinen's work was published in 1973 as his dissertation under the topic "Research on the Main Topics and Background of her Work". It is a thorough literary analysis of Kallas' production. In the title, her life is rendered only as a background, but, in fact, Laitinen made quite extensive research on her biography and the book also tells the life story of Aino Kallas. The latter part of the biography was not published until 1995. For a long time Laitinen's work remained the authorised analysis of Kallas' life and production, but during the 1990s feminist literary scholars such as Lea Rojola and Päivi Lappalainen started to analyse Kallas' production from different perspectives. See also Leskelä-Kärki 2009.

8. Lejeune launched his theory in the 1970s, and has continued to develop it further. It is a classical, often referenced theory. See Lejeune 1975; Kosonen 2000, 84 and 2007, 22. See also Lejeune's webpage "Autopact", where he explains his theory briefly in "Qu'est-ce que le pacte autobiographique?" http://www.autopacte.org (12.8.2010).

9. Simone de Beauvoir points out how energetic creativity is exceptional among older writers, usually old age does not favour literary creativity. For her, Voltaire and Hugo are lucky exceptions, as "... others pour water on to old tea leaves, or remain silent". She does not, though, reflect age and creativity from a gender perspective. (de Beauvoir [1970] 1992, 287-294.) In her interviews and psychoanalytical interpretations on female writers' creativity Pirkko Siltala, however, notices the meaning of creativity for older women writers (Siltala 1993, e.g., 133-135).

10. Kallas' poems have not been a key interest of researchers, and they have remained in the margins of Kallas' production regarded as somewhat old-fashioned poetry as compared to the renewal of Finnish poetry few years later. Modernists like Lassi Nummi, Lasse Heikkilä, Lauri Viita, Viljo Kajava, Helvi Juvonen and EevaLiisa Manner started publishing in 1949, and poetry was renewed in many ways (Enwald 2006, 11-14). Kallas' poems have, however, inspired composers: Tauno Pylkkänen, who composed several operas on Kallas' plays, also composed several poems from The Swan of Death for voice and piano in 1943. In 2009 a Finnish gay chorus Out ' $n$ loud uncovered a live recording of Touko Laaksonen's (later known in the United States as Tom of Finland) songs from 1949 and reconstructed it. In this collection there was a composition of Kallas' poem "Vihmalintu" [Drizzle Bird] from the collection Moon Bridge. Sixty years later, Out ' $n$ loud performed the song in London and in several places in Finland. (http://www.outnloud.fi/indexen. htm, 15.8.2010)

11. Onomatopoetic word used in many children's poems and songs referring to a command to a horse to hurry on.

12. Kallas had lost her newborn baby Lembit in 1906. Only one of her five children remained after she died in 1956, since also her daughter Virve died of cancer in 1954. The youngest of the children, Hillar lived until 1976.

13. The entire poem in Finnish: "Ah, surman luodit, jotka teihin sattu/ne mulle sinkos suoraan sydämeen/En kuollut; vain kuin elää varjo,/niin elän edelleen, kuin aave rauhaton./On kaipuu lohdutusta vailla,/se yhä viipyy kuolon mailla.//En vehreyttä 
enää näe maan,/en kukkaniityn kultaa,/en armautta suviauringon,/vain multaa, multaa, - /vain silmät suljetut,/suun iäksi vaienneen." (Kallas 1942, 146.)

14. The stanza of the poem in Finnish: "Katso, minä pakenin meren saarelle/niin kuin myrskyn sydämeen,/lammasten seassa minä lepään,/eivätkä ne säiky,/minä haihdun harmajaksi kiveksi,/eikä kukaan minua eroita,/kimalaiset kimpoavat hiuksistani,/ja vähät kukat povestani kurkoittuvat,/aurinko valkaisee minut ajopuuksi,/murheeni pakenevat, niin kuin kalaparvi matalassa/vedessä./Kuka taitaa minut löytää?” (Kallas 1942, 130.)

15. [... kai sen, minkä muutenkin tiedät: että olen elänyt "Kuoleman varjojen maassa", kohta kaksi vuotta.]

16. See Aino Kallas' letters to Aune Krohn 22.5.1942, 3.12.1944, 14.12.1944 and 4.2.1945, FLS LitA. See also Laitinen 1995b, 385 and 388.

17. [Aino Kallaksen runotar ei voi olla huolettomuuden eikä kepeän laulun muusa, koska se aika, joka on hänen runojensa taustana, on ollut täynnä ahdinkoa ja murhetta, vailla ilon päivää.]

18. [... vaan se odottaa ryhdikkäänä, ylväänä ja seestynein katsein vapautuksen kaikki sovittavaa hetkeä.]

19. [Teen työtä sellaisen ihmisen vauhdilla, joka tietää jäljelle jääneen aikansa lyhyyden. Kaikki muu saa väistyä tieltä, - työn vaatimus on entistä ehdottomampi. Se on nyt viimeinkin näin myöhäisessä elämässä ottanut minut jakamattomasti. Tämä vauhti on vaarallinen ja tietää loppua, - sekin on minulle selvää. ... Olen jo kaiken ulkopuolella, siltä tuntuu.]

20. [On niin kuin en jaksaisi kestää jokapäiväisen elämän menoa ilman "laulun lohdutusta".]

21. See more about the letter writing practices of Kallas and her family in LeskeläKärki 2006, 57-77 and passim; also Leskelä-Kärki 2007.

22. There is no direct translation for this sentence. According to Sirje Olesk from the Estonian literary museum it might be that this is some verse Oskar Kallas had told to his wife, maybe from the Estonian folksong tradition. It might also refer to a common verse "Ma laulan läbi murede", which could be translated: "I sing and grieve at the same time". Email from Sirje Olesk 24.6.2010.

23. [Olen 'hiki hatussa' kaksi päivää lukenut uuden kirjani korjausarkkeja, ja huomenna lähetän sen lopullisesti painoon. Mutta vanha virolainen kansanruno on oikeassa: laulu laulisteist murehi! Heti kun on yhdestä irtautunut, on jo toinen ovella, pysyvää tyydytystä ei milloinkaan. Luomispakkoni on ollut vuodesta 1942 alkaen suorastaan kuin kuumetila, enkä vieläkään tunne mitään lievennystä. Runoja, muistelmia, nyt viimeksi taas suorasanaisia legendoja. Polttoroviolla -runot ovat nyt myös painossa ja ilmestyvät tänä syksynä.]

24. [Kärsin syksyn pimeydestä, kuten aina, - tällä kertaa vielä tuntuvammin. Taistelen sitä vastaan kaikin keinoin, joista tehoavin on työ. Olen parina viime viikkona kirjoitellut suorasanaisia legendoja ja kronikoita, joitten yhteiseksi nimittäjäksi pitäisi tulla Seitsemän neitsyen tarina. Uudet kanssavaeltajani saat kai pian, pyysin Otavaa lähettämään ne suoraan Sinulle. - Kudon myös ahkerasti, sormikkaita ja villaröijyjä, se on rauhoittavaa eikä rasita silmiä - kutoivathan aikoinaan jo les tricoteuse't, vaikka päät putoilivat!]

25. Kallas' diaries from 1931 onwards have been missing from the 1940s on. She herself tried to locate them when starting to edit her diaries, but they were not found. Evidently, they had gone missing during the chaotic times in Estonia at the beginning of the 1940s. It is most probable that the diaries of the 1930s have been destroyed.

26. [Vaikka en vielä ennättänyt panna paperille kuin kahdeksan riviä, niin se jo helpoitti sydämen levotonta, kouraisevaa kipua.]

27. [... oli aika - Sulevin ja Lainen kuoltua - jolloin tuska ja kipu olivat niin ankaria, että niitten oli pakko purkautua runoksi, muuten olisin pakahtunut. Nykyiset yhtämittaiset, useinkin yölliset päiväkirjamerkintöni ovat sukua niille.] 
28. Kallas herself has mentioned only the diary from the 1930s, when discussing the missing diary extracts.

29. [ . .. puhtaan lyriikan alueelle olen lähtenyt silloin kun sisäinen tuska ja kipu on ollut liian raskas taakka kannettavaksi ja on hetkeksi helpoittunut saadessaan muodon. Se on kolmen viimeisen runokokoelmani syntytarina.]

30. Verse from the poem "Kuoleman lahjat" [Gifts of death], [Murheestani veistin linnun laulupuun,/iloks aamun auringon ja illan kuun] (Kallas 1942, 152).

31. See e.g., poems "Vihmalintu" [Drizzle bird], "Ihmelintu" [Miracle bird], "Säikkyneet linnut" [Scared birds]. Kallas 1943, 40, 42, 51.

32. The word "tuultaa" has been translated in several ways by e.g., Aili Nenola, a wellknown folklorist in her analysis of lamentations. She has used words such as alleviate, assuage, and relieve, but according to Senni Timonen "air out" could be the closest one. It does not, however, have the original meaning of the Finnish word in it. Originally the word was connected to the handling of grain and berries, to the process when they were cleaned, winnowed. The original, concrete meaning has gained a new symbolic meaning. (Timonen 2004, 350-354; email conversation with Senni Timonen 14.1. and 17.1.2010). Since the word 'winnow' has in it the concrete meaning as well, I decided to use it here. I would also like to thank Marlene Broemer for advicing me on this.

33. In the book I borrowed from the Turku University Library there is written under this poem: "Lamentations processed to lyric poetry." [Itkuvirsiä lyriikaksi jalostettuna] (Kallas 1943, 46-47). Since the book is part of the collection of V. A. Koskenniemi situated at the University Library of Turku, it is most probable that the comment is made by this influential literary figure, poet, and critic, who worked as the professor of Finnish Literature at the University of Turku in 1921-1948.

34. Original poem "Itku" translated by Dr.Phil Kalle Pihlainen in July 2010. This is the first translation to English of this poem. [Kun tulet vastaani tähtien valoisilla tanhuvilla,/tunnetko maammosi, kantajasi, poloisen synnyttäjäsi?/En ole tuntiakaan ollut sinua, ihanaistani, itkemättä,/sinua, ruskeasilmäistäni, mustakulmaistani, murehti-/matta.//Itken sinun kultaista sydäntäsi,/sinun heleätä hellyyttäsi katkerasti kaipaelen./Ennen emoasi lähdit teille tuntemattomille,/vaeltamaan outoja polkuja vaikenevassa maassa./Vai asustatko siellä autuaitten asuinsijoilla?/Uitko valkoisena joutsenena unelmien joella?/Ikävöinetkö takaisin ihmisten iloihin?/ Muistanetko vielä murehtijaasi,/itse autuaana, vaivoja vailla?//]

35. [Rakastan yhä vielä auringossa istumista, leikkiviä lapsia ja ennen kaikkea taiteellisen luomiskulun pakottavaa, usein tuskaisaakin, mutta sentään riemullista olotilaa.]

\section{References}

\section{Research objects}

Kallas, Aino 1942: Kuoleman joutsen. [Swan of Death.] Helsinki: Otava.

Kallas, Aino 1943: Kuun silta. [The Moon Bridge.] Helsinki: Otava.

Kallas, Aino 1945: Kanssavaeltajia ja ohikulkijoita. Muistoja ja muotokuvia. [Fellow

Travellers and Passers-by. Memories and Portraits.] Helsinki: Otava. (1945a)

Kallas, Aino 1945: Polttoroviolla. [At the Funeral Pyre.] Helsinki: Otava. (1945b)

Kallas, Aino 1953: Päiväkirja vuosilta 1907-1913. [Diary from the Years 1907-1913.] 
Helsinki: Otava.

Kallas, Aino 1957: Vaeltava vieraskirja vuosilta 1946-1956. [Wandering Guestbook from the Years 1946-1956.] Helsinki: Otava.

Vuorikuru, Silja (ed.) 2008: Elämisen taiteesta. Aino Kallaksen ja Anna-Maria Tallgrenin kirjeenvaihtoa. [The Art of Living. Correspondence of Aino Kallas and AnnaMaria Tallgren.] Helsinki: Otava.

\section{Unpublished sources}

Finnish Literary Society, Literary Archives (FLS LitA)

Aino Kallas' letters to Aune Krohn, from 1896-1956.

Aune Krohn's letters to Aino Kallas, from 1900-1956.

\section{Research literature}

de Beauvoir, Simone 1992: Vanhuus. Translated by Mirja Bolgár. Orig. La Vieillesse, 1970. Helsinki: Art House.

Bloom, Lynn 1996: 'I Write for myself and Strangers': Private Diaries as Public Documents. In: Suzanne L. Bunkers and Cynthia Huff (eds.), Inscribing the Daily: Critical Essays on Women's Diaries. Ed. Amherst: University of Massachusetts Press.

Enwald, Liisa 2006: Pohjajään ilo. Helvi Juvosen runoudesta. [The Joy of Ground Ice. On the Poetry of Helvi Juvonen.] Helsinki: Suomalaisen Kirjallisuuden Seura.

Eskola, Katarina 2003: Autius lehtipuissa. Elsa Enäjärvi-Haavion ja Martti Haavion päiväkirjat ja kirjeet 1942-1951. [Desolation of Deciduous Trees. Diaries and Letters of Elsa Enäjärvi-Haavio and Martti Haavio 1942-1951.] Helsinki: WSOY.

Hapuli, Ritva 2003: Ulkomailla. Maailmansotien välinen maailma suomalaisnaisten silmin. [Abroad. Finnish Women Travelling Between the Two World Wars.] Helsinki: Suomalaisen Kirjallisuuden Seura.

Kosonen, Päivi 2000: Elämät sanoissa. Eletty ja kerrottu epäjatkuvuus Sarrauten, Durasin, Robbe-Grillet'n ja Perecin omaelämäkerrallisissa teksteissä. [The Lived and Narrated Discontinuation in the Autobiographical Texts of Sarraute, Duras, Robbe-Grillet and Perec.] Helsinki: Tutkijaliitto.

Kosonen, Päivi 2004: Elämisen taidosta. Esseitä modernin kirjallisuuden tunnoista. [On the Art of Life. Essays on the Senses in Modern Literature.] Tampere: Tampereen yliopistopaino.

Kosonen, Päivi 2007: Isokrateesta Augustinukseen. Johdatus antiikin omaelämäkerralliseen kirjallisuuteen. [From Isocrates to Augustinus. Introduction to the Autobiographical Literature in Antiquity.] Jyväskylä: Atena.

Laitinen, Kai 1995: Aino Kallas 1897-1921. Tutkimus hänen tuotantonsa päälinjoista ja taustasta. [Aino Kallas 1897-1921. Research on the Main Topics and Background of her Work.] First edition in 1973. Helsinki: Otava. (1995a)

Laitinen, Kai 1995: Aino Kallaksen mestarivuodet. Tutkimus hänen tuotantonsa päälinjoista ja taustoista 1922-1956. [The Master Years of Aino Kallas. Research on the Main Topics and Background of her Work 1922 -1956.] Helsinki: Otava. (1995b)

Larsson, Lisbeth 2001: Sanning och konsekvens. Marika Stiernstedt, Ludvig Nordström och de biografiska berättelserna. [Truth and Consequence. Marika Stiernstedt, Ludvig Nordström and the Biographical Stories.] Stockholm: Nordstedts.

Lejeune, Philippe 1975: Le Pacte autobiographique. Paris: Seuil.

Leskelä-Kärki, Maarit 2006: Kirjoittaen maailmassa. Krohnin sisaret ja kirjallinen elämä. [The Krohn Sisters: Lives in Writing.] Helsinki: Suomalaisen Kirjallisuuden Seura.

Leskelä-Kärki, Maarit 2007: Constructing sisterly relations in epistolary practices: The writing Krohn sisters (1890-1950). NORA 2007/1. 
Leskelä-Kärki, Maarit 2008: Narrating life-stories in-between the fictional and the autobiographical. Qualitative Research, 2008/8.

Leskelä-Kärki, Maarit 2009: Aino Kallas suomalaisessa kulttuurissa. Kokemuksia, muistoja, tulkintoja. [Aino Kallas in the Finnish Culture. Experiences, Memories, Interpretations.] In: Maarit Leskelä-Kärki, Kukku Melkas and Ritva Hapuli (eds.), Aino Kallas. Tulkintoja tuotannosta ja elämästä. [Aino Kallas. Interpretations of Work and Life.] Helsinki: BTJ.

Makkonen, Anna 1999: “My own novel, Yes, Really!” The Early Diary of Aino Kallas and Reading for the Plot. Scandinavian Studies 71: 4.

Melkas, Kukku 2007: A Struggle for Knowledge: The Historical Novel and the Production of Knowledge. In: Päivi Lappalainen \& Lea Rojola (eds.), Women's Voices. Female Authors and Feminist Criticism in the Finnish Literary Tradition. Helsinki: Suomalaisen Kirjallisuuden Seura.

Melkas, Kukku 2006: Historia, halu ja tiedon käärme Aino Kallaksen proosatuotannos$s a$. [History, Desire, and the Serpent of Knowledge in the Works of Aino Kallas.] Helsinki: Suomalaisen Kirjallisuuden Seura.

Saresma, Tuija 2000: “On sattunut niin paljon ikävää." Kuolema, suru ja kirjoittamisen voima. [Death, Sorrow and the Power of Writing.] In: Maaria Linko, Tuija Saresma ja Erkki Vainikkala (eds.), Otteita kulttuurista. Kirjoituksia nykyajasta, tutkimuksesta ja elämäkerrallisuudesta. [Writings on Present, Research, and Biography.] Jyväskylä: Nykykulttuurin tutkimusyksikkö.

Saresma, Tuija 2007: Omaelämäkerran rajapinnoilla. Kuolema ja kirjoitus. [On the Borders of Autobiography. Death and Writing.] Jyväskylä: Nykykulttuurin tutkimusyksikkö.

Siltala, Pirkko 1993: Haen sanojani kaukaa. Naiskirjailijan luovuus. [I Search for My Words from Far. Woman Writer's Creativity.] Helsinki: Yliopistopaino.

Stanley, Liz 1992: The Auto/Biographical I. The Theory and practice of Feminist Auto/ Biography. Manchester and New York: Manchester University Press.

Timonen, Senni 2005: Minä, tila, tunne. Näkökulmia kalevalamittaiseen kansanlyriikkaan. [Self, Space, Emotion. Aspects of Kalevala-metre Folk Lyric.] Helsinki: Suomalaisen Kirjallisuuden Seura.

Tuohela, Kirsi 2008: Huhtikuun tekstit. Kolmen naisen koettu ja kirjoitettu melankolia 1870-1900. [April Texts. Three Women Writers Encountering Melancholia, 1870-1900.] Helsinki: Suomalaisen Kirjallisuuden Seura. 


\title{
The Aino Kallas Iconography
}

\author{
Interactive Self-Presentation
}

Today in both Finland and Estonia, in the eyes of the general public at least, Aino Kallas is probably more readily known by her physiognomy than through first-hand knowledge of her literary production. Her elegant looks have become familiar through a set of professional studio photographs, dating mainly from the 1920s and early 1930s when she was dwelling in London as the spouse of the Estonian ambassador, Oskar Kallas. ${ }^{1}$ These carefully posed and skilfully retouched photographs have made her image little short of iconic. The same images that were circulated in the Estonian, Finnish and British press, and also reproduced as advertisements and postcards provided by her publishing houses, sometimes drawn after photographs, are still constantly encountered as embellishments on book covers and on the pages of literary histories. The most commercialised example of these, perhaps, is a 1920s image recycled in a series of paper labels for "Alvaro" cigars, found in the archive of Otava, her publisher in Helsinki.

In photographs from the inter-war years we see an Aino Kallas moderately stylised as an emancipated New Woman, in a hairdo that almost looks bobbed although it is the case that her long hair has been curled and knotted at the back of her head, sometimes with a large black comb that almost became her trademark (fig. 1), ${ }^{2}$ or collected on both sides of her face. Born in 1878, Kallas most certainly did not belong to the generation of the young 'flappers' of the 1920s. Another main variant is a more youthful Kallas from the turn of the century through the 1910s, with a much more visibly built up hairdo, and a very distinct Art Nouveau air, a strongly feminised style that was, as such, widely popularised already in its own time (see e.g., Verhagen 1995). Both variants more often than not comprise a modest décolleté outlined with a decorative collar or a shawl, and in contrast to her dark hair, a white neck accentuated with jewellery. A mild exoticism around her darkness, signalling both spiritual depth and danger, is an integral part of the Kallasian mystique, and a direct link to a continentally inspired rhetoric of Decadence. ${ }^{3}$

However, three quite divergent early portrait paintings of Aino Kallas were brought out from the depths of the archives for a Kallas seminar organised in 2008 at the Estonian Literary Museum in Tartu. At first, it was relatively difficult to identify them as her portraits, and we were in fact 


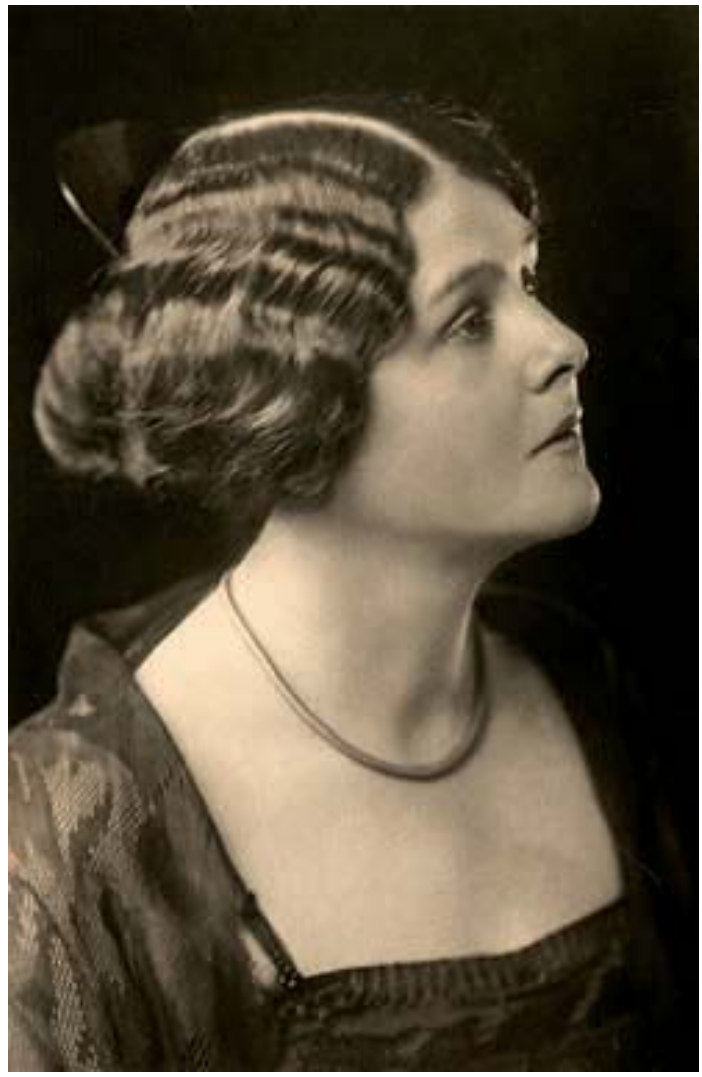

1 Photographic portrait of Aino Kallas, London, 1922, $13,9 \times 9 \mathrm{~cm}$. The Literary Archives of the Finnish Literature Society, Helsinki (Kia 2002:686:1). Photo: The Literary Archives of the Finnish Literature Society.

informed that their attribution was indeed somewhat uncertain. ${ }^{4}$ As we glanced through published material and did preliminary research through Google, we soon discovered that a few later portrait paintings of Kallas also existed, two of them at her publishing house, Otava in Finland.

Kallas' control of her images is reminiscent of another, more strongly mediatised female figure of the same era; the German actress Marlene Dietrich never cared to be painted but chose, instead, to be photographed in situations that enabled her to control the angles and lighting used for her portraits (Rewald 2006, 5). By the inter-war years at the latest, photography was generally seen as a more modern and up-to-date medium for portraiture than painting. Yet it could be expected that Aino Kallas, as a person more than twenty years senior to Dietrich, with a profession far less demi-monde than that of the film star, and positioned as a member of a prominent family amongst the Finnish cultural elite who was also the wife of a national figure in Estonia, would have had a certain proneness - coupled with the means - to follow the age-old tradition of having her portrait painted. Since she seems to have had a strong will, and obligation, to control her public image and even her afterimage, the fact that none of the painted portraits were ever circulated as photographic or drawn reproductions, is probably intentional. Many of them were also left behind when they moved from one country to another, in the case that they belonged to the Kallases at all. When diving into the archives, we also found some photographs that we did not remember ever having 
2 Photographic portrait of Aino Kallas, Studio Peeter Parikas, Tallinn, 1930 or before, $14 \times 9 \mathrm{~cm}$. The Estonian Literary Museum, Tartu (Fk A-37:3144). Photo: The Estonian Literary Museum / Alar Madisson.

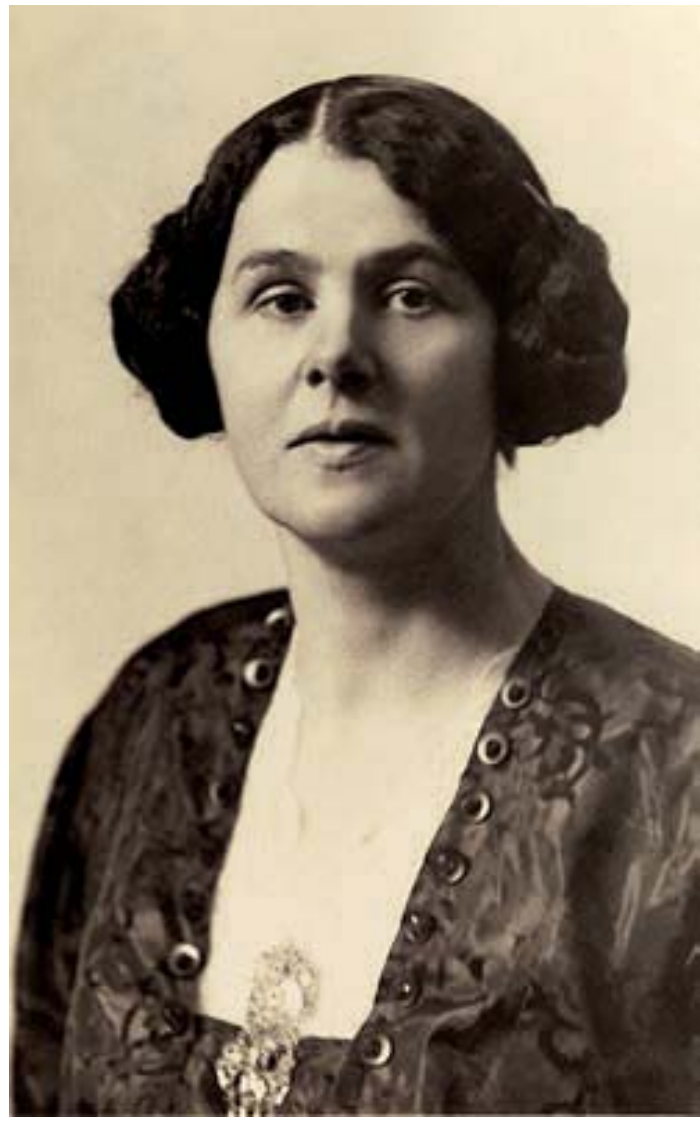

seen, such as a close-up taken in 1930 or at the end of the 1920s in Tallinn at the Parikas studio (fig. 2), the largest and most progressive Estonian studio of the time (Teder 1972, 69-73, 83-85; see also Linnap 2010, 527, 532-534, 693-694). The remaining prints of this particular image at the Otava archive bear a notation that they should not be used because the author was not fond of this particular image. ${ }^{5}$ Moreover, this indicates that Kallas was quite successful in controlling her public image.

What we found next was that her archive, that was donated to the Suomalaisen Kirjallisuuden Seura [Finnish Literature Society] in fact includes a hand-written list of her portraits, by Kallas herself (SKS, Kia; mentioned in Kallas 1989, 274). The manuscript is undated but can be traced back to the time in the 1950s - most probably early 1950s - when she was editing her diaries for publication and otherwise finalising her heritage for future generations. It contains a few numbers that are unknown today and neglects at least one that is mentioned elsewhere; whether this was done wilfully or by mistake is difficult to know. Equipped with this list, her other writings and the remaining images themselves we set out to decipher the Kallas iconography, at least partially, and to reflect on her own role in shaping it. ${ }^{6}$ Our hypothesis is that visual self-presentation was an integral part of her authorial strategies and that she set out to experiment with both 'traditional' and 'modern' female types and feminine styles. 
In her monograph on Kallas' prose production, Kukku Melkas (2006) analyses the ways in which Kallas created a thoroughly contemporary poetics through bringing historical and mythical female figures into new contexts and hybridising them in a fruitful way. She also identifies an autobiographical stance in this play with female characters. However, in fixing her own visual image Kallas needed to negotiate with others - professional artists and photographers - in more concrete terms. Fine art was a battleground of its own: a $20^{\text {th }}$ century artist, even when working on commission, tended to see a portrait as representative of her/his oeuvre and not only, or even predominantly, of the sitter. A painter may have had other viewers and viewing practices in mind than the ones that the sitter wished to address. Another factor, which further complicates the constellation, was the divergent notions and practices of authorship implicated by different visual techniques and technologies. The subject effects of the mediums of oil painting, drawing and photography would vary from one another and from situation to situation. While the intentions of the agents involved may be impossible to track down, some traces of these contested processes of presenting the modern woman remain to be investigated.

\section{The pleasures and shortcomings of sitting for a genius}

In her diaries, Aino Kallas refers to at least seven different artists for whom she sat at some point in her life. In addition, one more painter is mentioned in the biographical literature. However, only five remaining works can be identified with certainty as her portraits and attributed to a certain painter. Three of them, a pastel and a lithographic print by Väinö Hämäläinen (1917) and an oil painting by Martta Helminen (1952) are owned by her publisher Otava. One is an early painting by the French artist Antonie Boubong (1899), now at the Estonian Literary Museum in Tartu. The fifth one is a paradox: a work by the Latvian painter Janis Rozentāls that is no longer a portrait of Aino Kallas (1916, private coll.). Yet there is a version of it, partly copied and partly refashioned into a portrait of the author by Martta Helminen in 1950 (private coll.). In addition to these, we can with far less certainty identify four portraits and/or their makers.

Like so many sitters in the long history of portrait painting, Kallas had a very critical view of most of the portraits painted of her. In her diary, which she later edited herself, there is an entry on 18 February 1917:

Väinö Hämäläinen made a request to paint me. This means that I should sit for a third time within one half of a year, and on top of this Jaan Koort wanted to sculpt my portrait, yet I declined.

Rosenthal, Kuutola, Hämäläinen ...

Why, why did not Jan paint a true portrait of me! To him - and him only could I have shown my soul instead of my mere countenance!

He did not do it, and nothing else matters. Being "painterly" in this way of course flatters my ego, but at the same time each new sitting is a bittersweet remembrance to me. (Kallas 1954, 60.) ${ }^{7}$ 


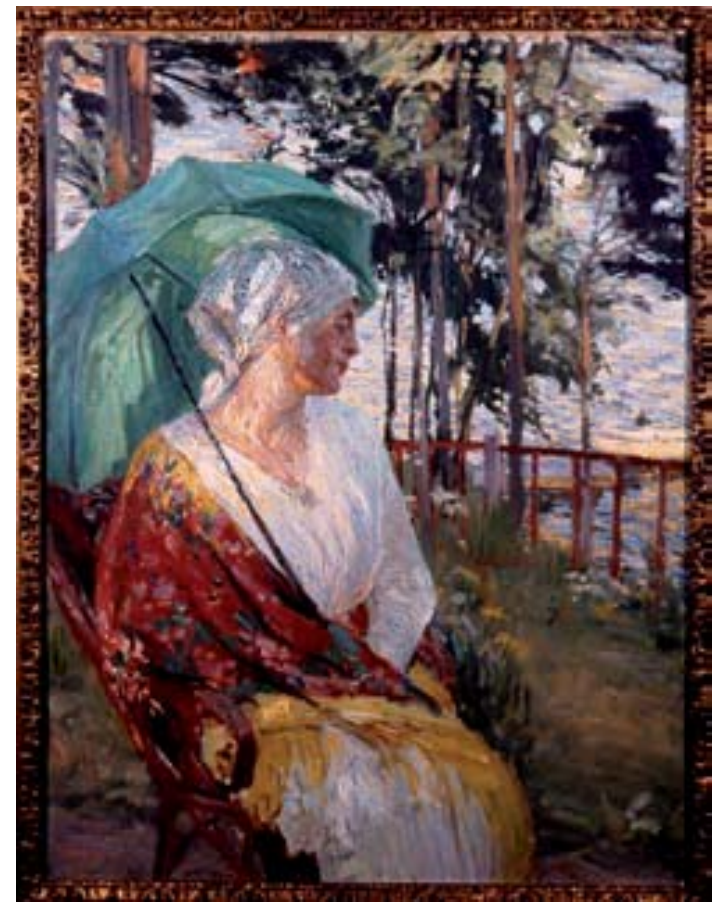

3 Janis Rozentāls, transformed portrait of Aino Kallas, 1916, oil on canvas, $70 \times 54,2 \mathrm{~cm}$. Private collection, Finland. Photo: The archive of Otava.

"Jan" here refers to Janis Rozentāls (1866-1916) who had with his family fled Latvia in fear of the approaching war and settled in his wife's home country, Finland; Kallas tends to use the German version of his name, Jan Rosenthal, as German was their language of communication. ${ }^{8}$ Part of her emotionality can in this case be attributed to the specificities of the situation: Rozentāls had unexpectedly died in Helsinki just a few months earlier, and their meeting in the preceding summer, of 1916, had involved intense flirting, at the least. ${ }^{9}$

In the list of her portraits written in the 1950s Kallas, in retrospect, laconically mentions that since the portrait remained unfinished, Rozentāls replaced the head with that of another person (fig. 3). To this she adds that she lost track of the painting after his death but rediscovered it in Finland ${ }^{10}$ and had Martta Helminen copy it (fig. 4) and re-enter her head into the copy with the help of a photo taken in London (cf. e.g., fig. 15) ${ }^{11}$ (SKS, Kia; see also Kallas 1989, 274). The annotation has a cool and documentary tone but tells in practice a more passionate story: after so many decades Kallas still wanted to repair this symbolic defacement made by an artist she respected and to whom she felt attached. This is indeed the way that a defacement of a portrait functions in almost any circumstances, but the incident may tell us something more specific about Kallas' ways of managing her identity in visual terms. It at least refers to a more intimate side of this self-management. Although the document was probably written to be found by future researchers and biographers, the therapeutic act itself - of letting the painting be copied and repaired - seems quite personal in nature. The copy with the facial re-replacement was kept by Kallas herself and has remained in the family (Kallas 1989, 274). 


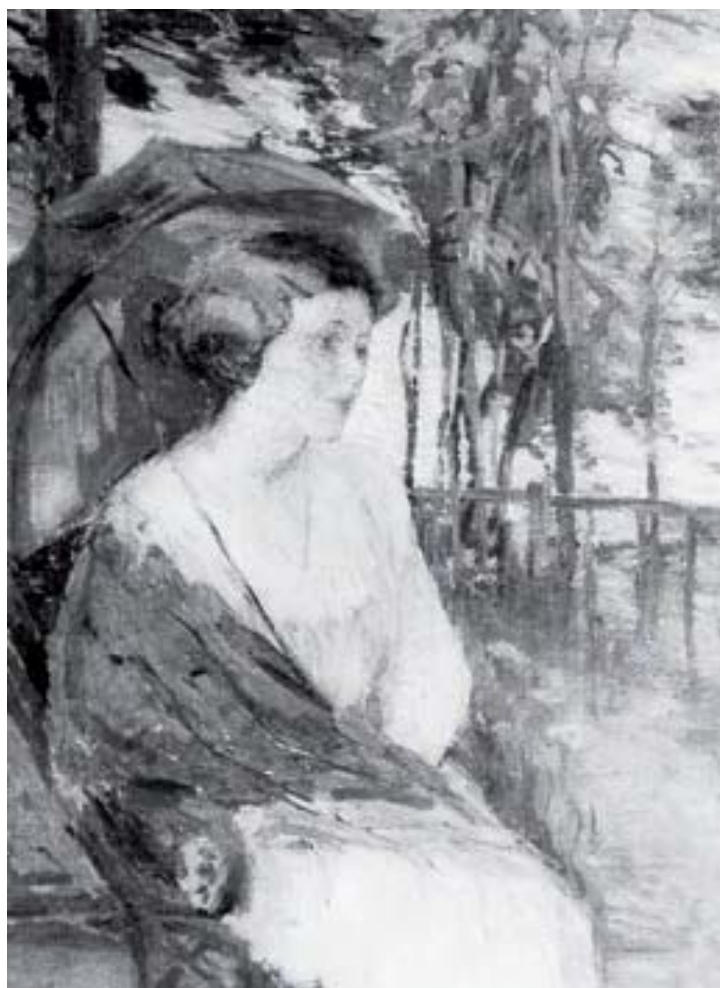
4 Martta Helminen, portrait of Aino Kal- las painted after Janis Rozentāls, 1950, oil on canvas, sight size $67,5 x$ $50,5 \mathrm{~cm}$. Private collec- tion, Finland. Photo: The archive of Otava.

The motive for the effacement is unclear, but the process described above indicates that it was a question of insulting the sitter; the insult is especially clear in that her face was replaced by that of the painter's housemaid (Kallas 1957,36 , cf. note 10). In an anthology of literary portrait sketches published soon after Oskar Kallas' death in 1946, and dedicated to him, she recounts in a much more light-hearted mode her meeting with the painter and denies the personal attachment between them by stating that at the height of the intensity of the painting act, towards the waning of the day, she understood that she had become "just a painter's model"12 for him (Kallas 1946, 134). She also claims that the painting remained unfinished because of her own engagements elsewhere and explicitly underlines the surprisingly "classical pure features", "Hellenic" even, of her replacement, a maid from the province of Savolax who always wore a white headscarf - a reference to a nationalistic folklore discourse that seeks to de-eroticise the painter's move. ${ }^{13}$ The melancholy, dreamy "Finnish" face is depicted from a strained full-profile angle that makes it sit quite uneasily on the body seated comfortably in a willow chair under a parasol. This awkwardness seems to be a result of the fact that the face is a direct citation from another painting from the same year, known by the title Finnish Maiden. ${ }^{14}$ In this pastel, the half-closed eyes and impractical white clothing suit equally awkwardly the figure of a robust maid carrying a coffee tray. In the Finnish Maiden, too, the motif seems more of a pretext for studying the bodily presence and facial features of a youngish woman.

Kallas' account of her first sitting with Rozentāls, on 26 June 1916, had a very different tone. Kallas had promised to stay two weeks with the 
Rozentālses in the vicinity of Helsinki in their Kulosaari villa that functioned as a combination of studio and boarding house, and where the artist "presumably" wanted to paint her (Kallas 1954, 13). This meeting is still coloured by the ending of Kallas' 13-year long attachment to the Estonian psychiatrist and literary critic Juhan Luiga (Kallas 1954, 15):

\begin{abstract}
My soul is yearning and hot, it is only my body which has never experienced a sensual rush.

Yesterday I encountered a great enjoyment: Right away as Jan Rosenthal entered [his studio] I noticed that the painter, the artist in him was awakened. I was wearing a white dress, my hair pinned up on my ears. [...] Jan let his daughter go and fetch different kinds of colourful scarfs in which he draped me.

"I never wear anything colourful," I said, "it does not suit my soul, I always wear just black and white".

"No, a contrast should be added to do justice to your fine, gentle colours." (Kallas $1954,13.)^{15}$
\end{abstract}

What is especially characteristic of Kallas here is her way of carefully describing her attire and hairdo. She was never ashamed of directly judging the appearance of either herself or others. In 1946 she, for example, published an essay titled "Estonian Beauties" [Virolaisia kaunottaria], trying to specify the characteristics of the particular ethnic type (Kallas 1946, 124-126). Some features of the description remind the reader of Kallas' own preferences. According to her, Ants Laikmaa, Nikolai Triik and August Jansen were the Estonian portrait painters who were most willing to follow their female sitters' most secret desires: "with exposed arms, wearing necklaces of genuine - or why not! - artificial pearls, in the way that they circulated at the receptions given by the riigivanema [the President of Estonia], the Minister of Foreign Affairs and the embassies of foreign states"16 (Kallas 1946, 125). During the following year, in the spring of 1947 she self-consciously wrote in a letter to her friend Anna-Maria Tallgren that her own "silk-black' [hair]" is but a memory any more, having turned - and also been left - genuinely mousegray" ${ }^{17}$ (Stockholm, 7 April 1947, printed in Vuorikuru 2008, 302). It is at this time that she finally had her hair bobbed, too. In this way she acknowledged having given up her tendency of fetishising feminine hair in the manner that was more or less shared by the whole Symbolist movement.

Kallas also seemed quite consistent in her "monochromatic" inclination which may be one reason why the rather happily impressionistic, softly colourful image - containing warm red and yellow hues - refashioned by Martta Helminen never became publicised. It is a very feminised and private view of the person and underlines rather her position as a member of the "leisured class" instead of her personal qualities, such as the intellectual rigour demanded by her profession. The reparative gesture achieved with the help of her artist friend Helminen did not change the fact that Kallas was just one part of Rozentāls' artistic experimentations with painterly techniques and generalised female imagery. Moreover, as her diary entry from February 1917 indicates, Kallas was conscious of the artist's potential to produce much more individualised and captivating portraits, if he so willed 
5 Martta Helminen, Portrait of Aino Kallas, 1952, oil on canvas, $46,5 \times 39 \mathrm{~cm}$. The archive of Otava, Helsinki. Photo: The archive of Otava.

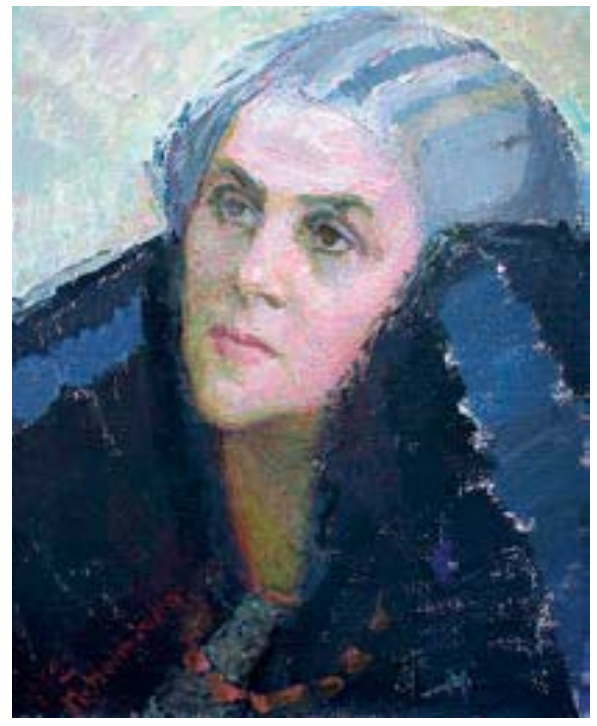

(Kallas 1954, 60). This becomes manifest in his portraits of another Finnish female author, Maila Talvio - his wife's cousin - from 1904 and 1916 (both today in the collections of the Satakunta Museum in Pori, Finland).$^{18}$

\section{Various attempts at approaching the female writer}

Martta Helminen (1890-1983) was an artist who moved from Tampere to Helsinki at the end of the 1920s and settled in a wooden villa by the coastline in Meilahti together with the journalist and women's movement activist Göta Sinervo (b. Salovius). In the 1930s they both worked for a cultural journal titled Aamu [Morning], while Helminen also painted portraits by commission (Kallas 1989, 339; Martta Helminen 1999). Kallas contributed to the journal from London. ${ }^{19}$ As can be seen from a later text describing the hospitality and convivial atmosphere at the "Meilahti 13" villa, ${ }^{20}$ the author counted them among her good friends (Kallas 1947, 89-91). She mainly visited them in Meilahti in the late 1940s and early 1950s (Kallas 1989, 339) when Helminen may also have executed the other two portraits of Kallas mentioned in her hand-written list (SKS, Kia). ${ }^{21}$ In 1949 she possibly stayed with them for a bit longer while attending to a health problem at her doctor's in Helsinki (Kallas 1989, 349). Sinervo and Helminen both contributed to Kallas' career as loyal members of a sort of women's network that possibly also included the author L. Onerva and the critic Anna-Maria Tallgren. Except for Sinervo they did not partake actively in the women's movement, but discussed in many direct or indirect ways burning issues concerning gender and sexuality.

Helminen's late portraits seem to have satisfied the author to some extent at least. The finalised oil painting owned by Otava, signed in 1952, is just a simple head, however, but manages with the upraised fur collars, visible make-up and a piece of bright red jewellery to present the sitter as an extravagant and dramatic woman of the world (fig. 5). ${ }^{22}$ With the means of painting, 


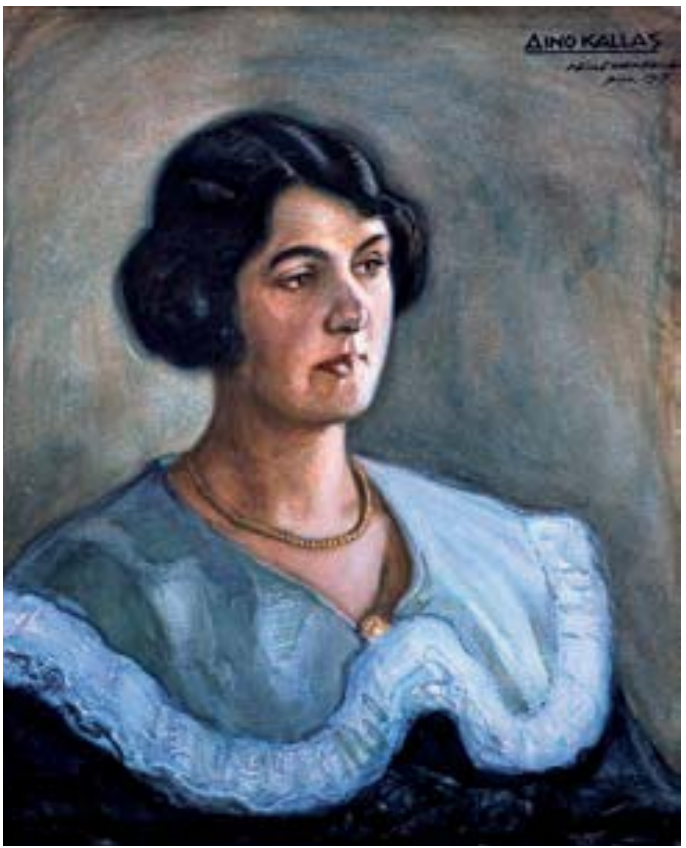

6 Väinö Hämäläinen, Portrait of Aino Kallas, 1917, pastel on paper, $62 \times 51 \mathrm{~cm}$. The archive of Otava, Helsinki. Photo: Toimituskuva / Matti Ruotsalainen.

this piece probably comes closest to the kind of contemporaneity and glamour that Kallas was aspiring to with the means of professional studio photographs. Still it is far less known than the photographs. Two other portraits, or rather sketches made in oil, by two Finnish women painters mentioned in Kallas' list (SKS, Kia), namely Anna Snellman-Kaila and Meri Genetz, both from approximately 1920, have not been located. In her memoirs Kallas in fact mentions Snellman-Kaila more as the spouse of the philosopher Eino Kaila, rather than as an artist, and mainly expresses her amazement at the painter's charmingly girlish way of "twittering" like a bird (Kallas 1946, 157158; Kallas 1954, 61) ${ }^{23}$ Of the portrait she, moreover, states that it probably remained only a sketch and was made "in the same year" during which she was sitting for so many others as well (Kallas 1946, 158).

The majority of the portraits or portrait sketches made of Kallas by professional artists indeed centre around the years 1916-1917 and 1920. This is the period when she was becoming increasingly well-known as a writer, and therefore a more lucrative object of portrayal, also in terms of professional reference. The male painter Väinö Hämäläinen probably met her through her sister Helmi Krohn, or otherwise in the context of the publishing house Otava. At the time when he requested to paint her likeness, in 1917, he was doing illustrations for publications in which Helmi Krohn was involved (see Lohi 2005, 158-160). Since both of the portraits by him, executed in two different bust-length versions, one in pastel and the other in lithography, ended up at the publisher's, they probably represented part of the artist's livelihood; the times were hard for the profession. As her fame grew, this - coupled with genuine admiration for her as an author - was most certainly behind many other requests, as well. One must say that it is no wonder that the pastel by Hämäläinen (fig. 6) did not become a favourite of Kallas. The dramatic 


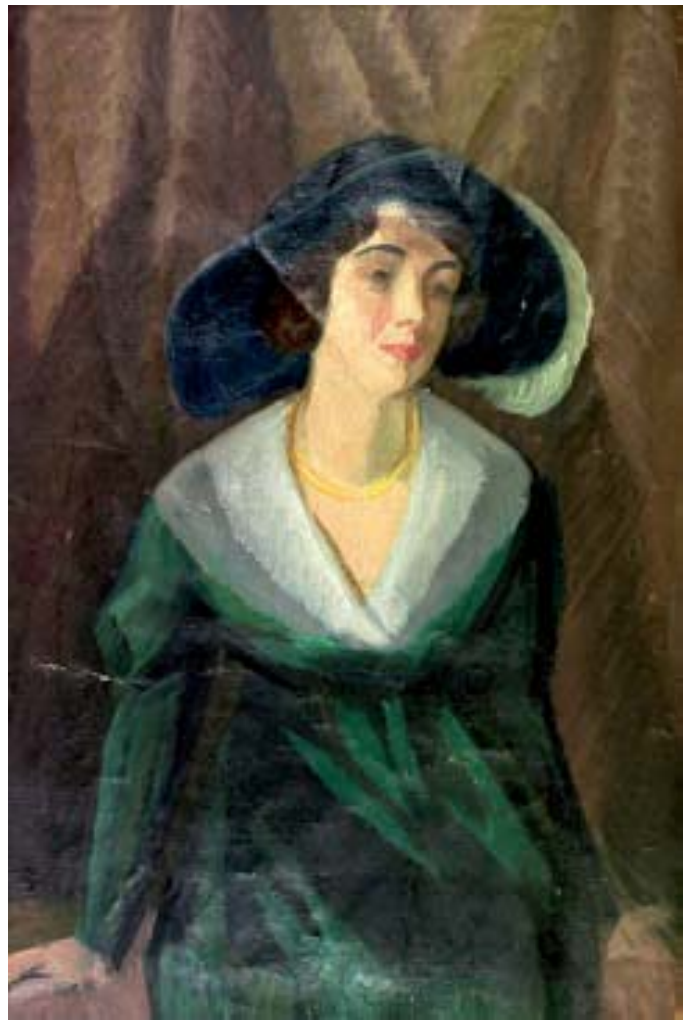

7 Kalle Kuutola (?), Portrait of a Lady (portrait sketch of Aino Kallas?), 1917, oil on canvas, $42,8 \times 29,2 \mathrm{~cm}$. The Estonian Literary Museum, Tartu (KM 18). Photo: The Estonian Literary Museum / Alar Madisson.

yet clumsy white collar dominates the image rather absurdly, questioning the precedence of the face as the key instrument in presenting the sitter's personality, and manifests an insensitive and disrespectful interpretation of Kallas' interest in matters of style.

There are a couple of more ambitious approaches to the Aino Kallas iconography, also in terms of Modernist aesthetics. One of these is probably by the Finnish painter Kalle Kuutola (1886-1974) whom Kallas mentions, together with "Rosenthal" and Hämäläinen, in her diary entry of 18 February 1917. In a previous entry of 7 October 1916 she had explained how on that evening at an opening of an exhibition in Helsinki an artist "completely unknown" to her had had himself presented to her in order to make a request to portray her (Kallas 1954, 36). The plan progressed swiftly since by 12 October she had already given him two days. Kuutola had the severe disadvantage of a fresh comparison to Janis Rozentāls of whom Kallas exclaims: he "would have been able to paint me; he knew me", whereas the picture by Kuutola had scarce chances of catching her interest with its, according to the sitter herself, "alien and probably superficially done facial expression" (Kallas 1954, 36-37). ${ }^{24}$ In her 1950s document on her portraits, she claims that the picture remained with the artist (SKS, Kia). Still it seems possible that it might be connected to an unattributed, unsigned and undated oil painting of an unknown lady at the Estonian Literary Museum in Tartu (fig. 7), that has ended up in the archive in 1946 through a collection donated by Aino and Oskar Kallas. 


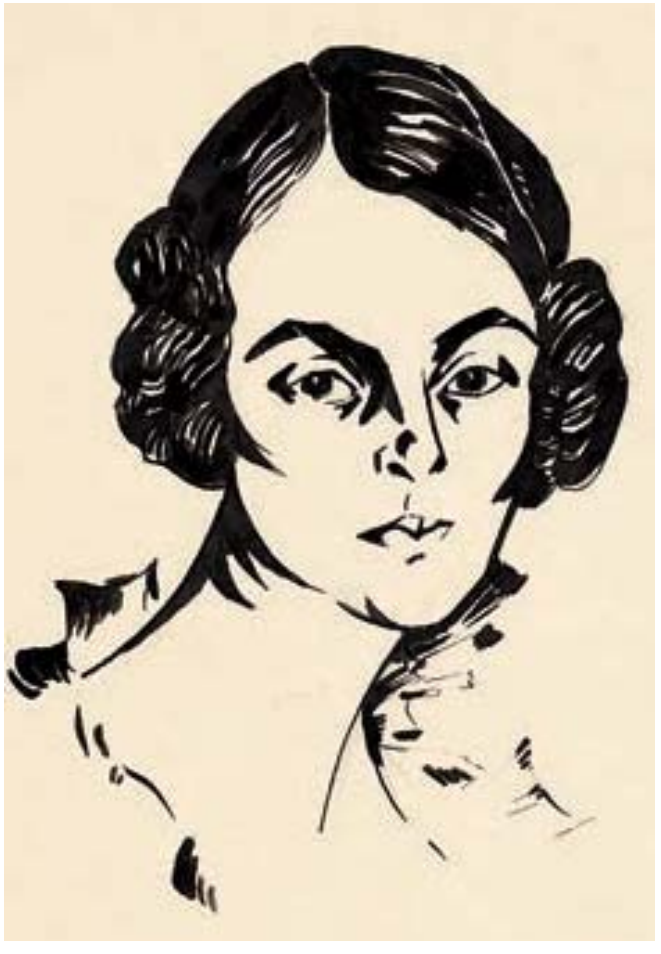

8 Konrad Mägi, Portrait of Aino Kallas, 1918, ink on paper, $34,6 \times 25,3 \mathrm{~cm}$. The Art Museum of Estonia, Tallinn (EKM G 19328). Photo: The Art Museum of Estonia / Stanislav Stepashko.

This collection comprised material left in Tallinn as the family fled the war to Stockholm. ${ }^{25}$

This unframed and slightly rumpled canvas of 42,8 by 29,2 centimetres has been classified by the museum staff as a sketch; it is plausible that it would have been taken off the frame and transferred in haste, or carelessly stored for a longer time. Aino Kallas could have either strategically or genuinely forgotten about this. The style of the painting that represents a woman in a darkish green dress rounded by a white collar, wearing a handsome plumed hat, with her dark hair pinned up to frame her face, could be described as modestly Cubist. In its emotional detachment, the painting does not really make an attempt at catching a likeness. Still there is a detail that is analogous with many portrait photographs of Aino Kallas: the lady wears around her neck a heavy piece of golden jewellery, crafted in the form of a snake. The broken colour scheme as well as the particular - rather unanalytic - way of adapting a Cubistic method of composition remind us of figure paintings, usually of women, that Kuutola made between 1916-1917 (cf. Räty 1990, 12-13). Moreover, the curator of a recent Kuutola retrospective, Leena Räty, has kindly expressed her view that the method of execution in this painting (which she saw as a reproduction) is well in concordance with Kuutola's production of the mentioned years. She also added that Kuutola usually only signed his paintings when he considered them finished. ${ }^{26}$ While the matter cannot be clearly ascertained, this analysis suggests quite strongly that this piece should be identified in the least case as a sketch for the portrait that Kallas mentioned in her diary.

Another, more serious and successful attempt at Modernist experimentation with Aino Kallas' likeness can be documented in Estonia. Sympto- 


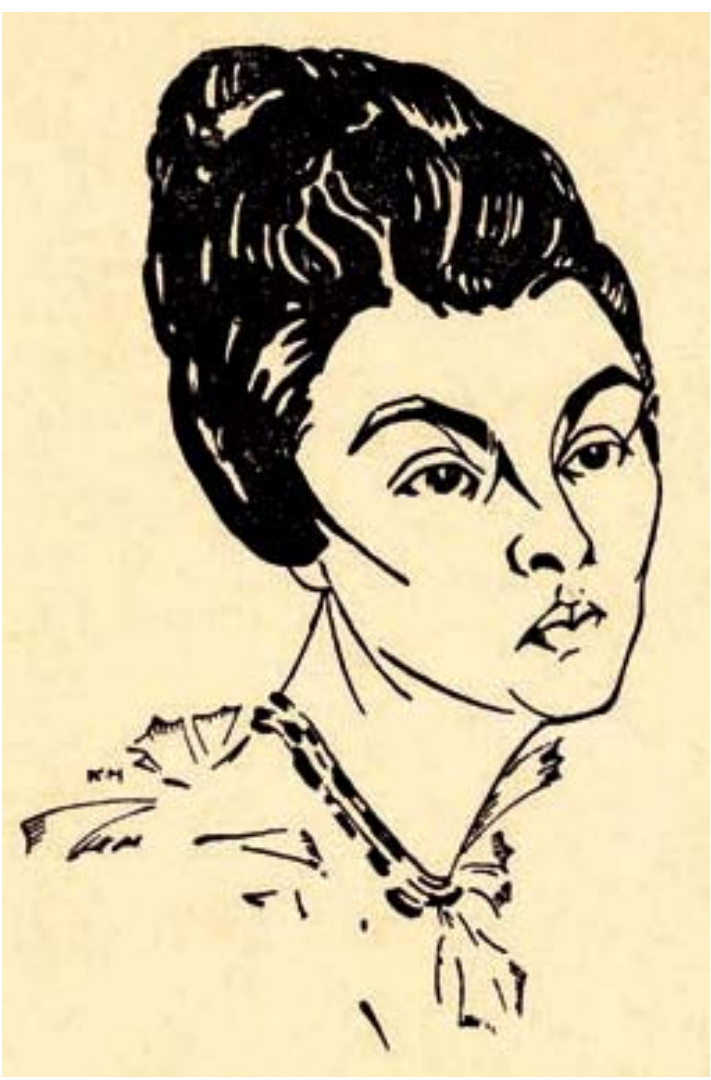

9 Konrad Mägi, postcard of Aino Kallas, $14 \times 9 \mathrm{~cm}$. The Estonian Literary Museum, Tartu (F $1 M$ 2:17, pp 6/6). Photo: The Estonian Literary Museum / Alar Madisson.

matically enough, this was done in an altogether different genre, that of illustrative drawing, with a larger, culturally minded audience in mind. In 1918 the Estonian artist Konrad Mägi (1878-1925) made two interesting ink drawings of her. One of them is preserved as an original drawing in the collection of the Art Museum of Estonia in Tallinn (fig. 8), while the other one is only known as a postcard in a series comprising thirteen authors and artists, printed by the publisher Odamees between 1918-1920 (fig. 9). Interestingly enough, one of the portrayed figures was altogether fictive. ${ }^{27}$ The drawings chosen for the postcards also appeared in the journal Odamees, but the preserved original drawing of Kallas never seems to have been published. Taking likenesses in ink was something that Mägi took up during a visit to a writers' colony in Pühajärve in Southern Estonia in the summer of 1918. In the 1930s the art historian Rudolf (Rud) Paris compared this undertaking with a series of artistic physiognomies that were made of French Symbolist writers by the painter Félix Vallotton and circulated in Estonia through a Russian translation of Remy de Gourmont's Le Livre des Masques that originally appeared in two volumes in 1896-1898 (Paris 1932, 194-197). ${ }^{28}$ This was the first and only explicit visual link to Symbolism and Decadence in the Aino Kallas iconography that is known to us. However, the more contrastive style of the drawings by Mägi also seems to allude to later Russian Formalist adaptations of French Cubism. 
In his portrayals of Kallas, Mägi emphasises her eyes and eyebrows in a way that can be read as a sign of intellectual capacity, while the elongated neck and the delicate neckline, not visible in the male portraits, function as a gender attribute. The printed image - with its high and lavish hairdo - corresponds to the 'Art Nouveau' Kallas type described earlier, whereas the original drawing - with her hair collected on the ears - comes closer to the 'New Woman' variant of her iconography. Mägi based his series of author portraits either on live situations or photographs, but might have also worked from memory (Pihlak 1979, 117-118). Which is the case in conjunction with the Kallas portraits is difficult to determine.

It is clear, however, that these drawings, advocating authorial integrity for both the sitter and the maker, unlike most of the painted likenesses of Kallas, were the result of intensive professional interaction between cultural agents. During the first decades of the $20^{\text {th }}$ century when Kallas actively partook in the cultural life in Estonia, she was the only female member of the literary circle Noor-Eesti [Young Estonia]. The art historian Alfred Waga $(1938,19)$ has argued that visual artists joined the group of writers through the personal interest that its leading figure, Gustav Suits, ${ }^{29}$ took in the production of the painter Ants Laikmaa (1866-1942, named Hans Laipman until 1935). By 1904 at the latest, Suits and Laikmaa were the key agents in planning the first public art exhibition and the first art society in Estonia (e.g., Tiik 1972, 45, 54-59). The results were to be expected only later, though. In 1912 a new effort at institutionalisation of the art scene was made by the NoorEesti society with Konrad Mägi as the initiator. Mägi had been a student of the now expelled Laikmaa and was himself the only returning artist of the younger generation. This time Noor-Eesti was able to establish continuous exhibition activity in Tartu. Aino Kallas functioned at some point as a jury member, together with the male painters Mägi ${ }^{30}$ and Kristjan Raud. (Hinnov 1972, 20; see also Pütsep 1991, e.g., 342.) At the literary soiree arranged in conjunction with the exhibition, Kallas, as the sole woman, once again, made a "grand" appearance by reading her still unpublished novella from 1908, Bernhard Riives (Laitinen 1973, 125; Pütsep 1991, 330). A few years later, in 1917, Kallas represented Noor-Eesti in the organising committee of a planned art festival (Pütsep 1991, 362).

In her list of portraits (SKS, Kia) Kallas mentions a bust-length oil painting that Mägi made of her in Tartu. According to her note, the artist kept the picture that later was lost. In his extensive monograph on Mägi, Rudolf Paris $(1932,271)$ also mentions that a portrait of Kallas was done between 1918-1921, but he had no knowledge of its whereabouts. Thus, we can only speculate whether the painting looked anything like the two drawings from the same time. According to the art historian Evi Pihlak, Mägi liked to portray emancipated, independent urban women, most preferably in the case that he found their looks dark and exotic; an aspect he could also emphasise through his artistic means (Pihlak 1979, 85-88; see also Kompus 1917). He also shared the fascination with androgyny, characteristic of the Noor-Eesti circle (Raitar 27 November 1998). It is a pity that this portrait, with its possibly more Decadent notion of womanhood, has not survived. However, a charcoal drawing by Mägi in the collections of the Art Museum of Estonia 


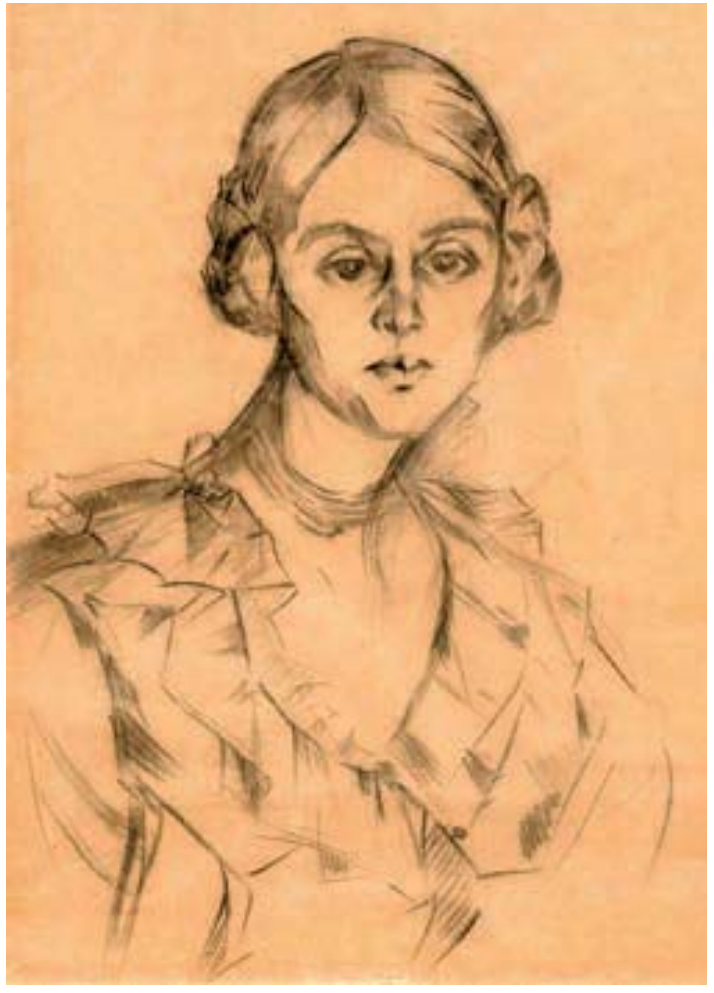

10 Konrad Mägi, Portrait of Aino Kallas, 1918, charcoal on paper, $60 x$ $44,6 \mathrm{~cm}$. The Art Museum of Estonia, Tallinn (EKM G 19327). Photo: The Art Museum of Estonia / Stanislav Stepashko.

(fig. 10) ${ }^{31}$ might just be a sketch for this portrait. The composition is rather similar to the unpublished ink drawing, although slightly shifted in perspective, yet it is not a line drawing but a bit more rounded figure, with fuller psychological characterisation as well.

This more Modernist strand of the Aino Kallas iconography does not seem to have had a following in Estonia either. In the Soviet times, moreover, Kallas was not a politically correct author. It can be noted, though, that the figure of Kallas has incited posthumous admiration. As far as we know, the only portrait bust ever sculpted of her was made in marble in 1978 - the centennial of her birth - by a female artist Erna Viitol (1920-2001). This bust that cites a kind of a Modernist rhetoric is today owned by the Estonian Literary Museum (fig. 11). As a posthumous work, its primary inspiration has been Kallas' texts and less her person..$^{32}$ As for the iconographic type, the younger one with a more lavish hairdo has been chosen.

\section{Depictions of Kallas as a great lady of society}

The three paintings shown during the Kallas seminar at the Estonian Literary Museum have in our investigation turned out to be among the least "literary" in nature. They could rather be characterised as representative portraits in which the social status of the person - as a daughter and a wife - is underlined. In this genre the femininity of a female sitter turns into a marked class attribute signalling an upper or upper middle-class posi- 
11 Erna Viitol, Aino Kallas, 1978, marble, $46 \times 31 \times 54 \mathrm{~cm}$. The Estonian Literary Museum, Tartu (KM Ks 53). Photo: The Estonian Literary Museum / Alar Madisson.

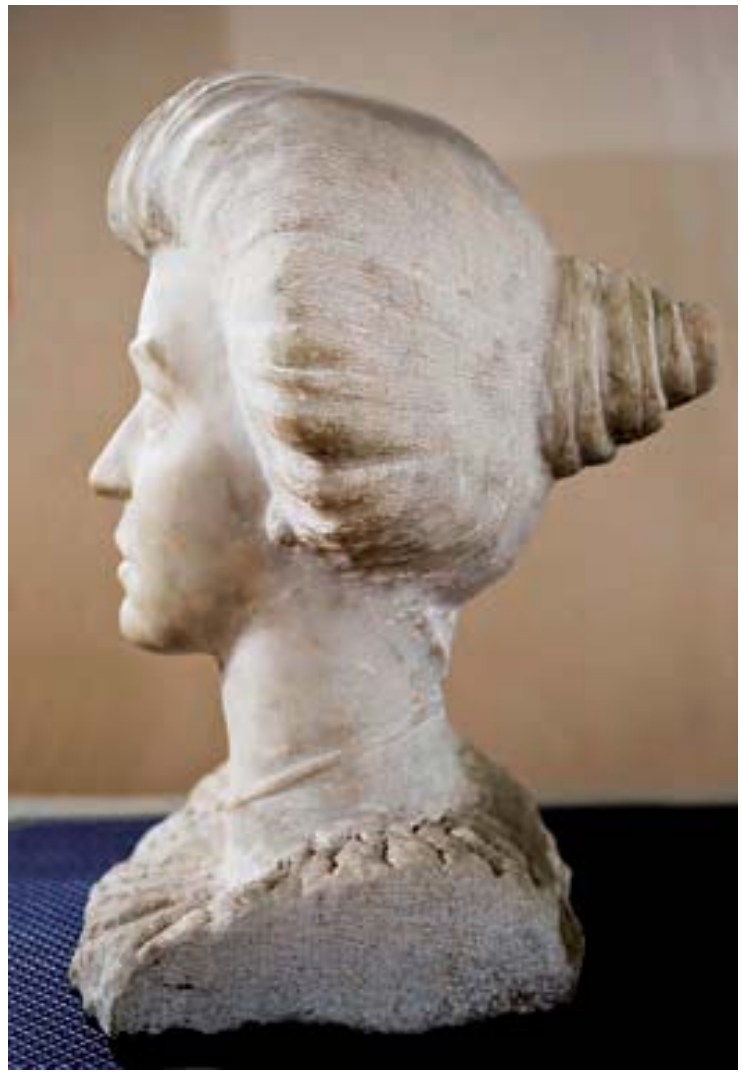

tion. Femininity was simply a luxury that the lower classes could not to the same extent afford. In this particular context, the fact that two of the paintings in Tartu are pastels further strengthens the intersection of class and gender. Within the more representative genre, the tradition of pastel portraits associated specifically with the 18th century - the epoch preceding the French Revolution - and the exquisite femininity of the nobility and court culture, implicating at that time both women and men (see e.g., Wichstrøm 2000).

The earliest pastel portrait of Aino Kallas (née Krohn) is placed in an oval frame likewise connoting earlier centuries (fig. 12). It was made in February 1899, prior to her marriage, in Strasbourg, at that time part of Germany. The author recounts in her diary that "a paintress, miss Boubong" had inquired after the possibility to do a pastel portrait of her, and that she sat for her in her very becoming blue silk dress, which reminded her of many a pleasant evening from the preceding summer (Kallas 1952, 144). Before travelling to Europe, Kallas had been taking leave of a Herman Stenberg, an early object of her powers of fascination. The portrait presents an en face view of a "pretty" young woman with the clearest brown eyes. Antonie Boubong (1842-1908), a painter of portraits, genre pieces and landscapes active in Strasbourg at the time, ${ }^{33}$ has clearly signed the simple but professionally executed portrait ("A. Boubong 1899 Strasbourg") of which we know no more. 


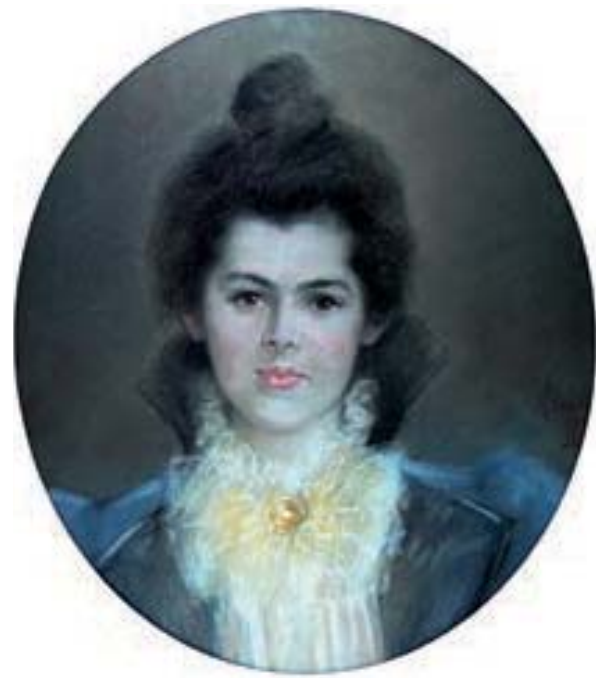

12 Antonie Boubong, A. Kallas, 1899, pastel, $59,5 \times 50 \mathrm{~cm}$. The Estonian Literary Museum, Tartu (KM 15). Photo: The Estonian Literary Museum / Alar Madisson.

The other pastel, likewise in an oval frame, is unsigned (fig. 13). It has been assumed, though, that it might be by Ants Laikmaa who was known for his pastels. This is very plausible indeed, especially since the attitude of the sitter, glancing a bit to the side while standing diagonally at a notable distance from the viewer, seems to belong to a life-sized portrait, originally a state portrait format that was established as a representative genre for the rising capitalist bourgeoisie during the late 19th century. In northern Europe this bold and flamboyant genre was more often assumed for the portraits of self-assured actresses and singer divas, such as Albert Edelfelt's portrait of Aino Ackté, the first Finnish soprano to claim international fame (1901, oil on canvas, Ateneum Art Museum, Helsinki). In her account of her portraits (SKS, Kia) Kallas mentions that Laikmaa painted a full-length portrait of her that was cut down to bust-length after the glass sheltering the pastel broke. The oval portrait could very well be the fragment left over from a larger painting because the voluminous hat that crowns her hairdo simply seems too large for the composition and the pose oddly distanced for such an intimate format.

The art historian Vaike Tiik has summarised on the basis of Kallas' correspondence that Laikmaa's portrait would have been of handsome dimensions $(200 \times 98 \mathrm{~cm})$ and that it was finalised in April 1915 in only a few days (Tiik 1996; see also Kallas 1953, 349). The painting had been begun ten years earlier but left unfinished, which puzzled the artist who was repeatedly in contact with Oskar Kallas over the matter. Mainly the sitter's dress was reworked whereafter the portrait was hung on the wall of the Kallases' Tartu home. (Tiik 1996.)

The painting was probably begun in Tartu in August 1906 when Laikmaa was visiting the city for the first exhibition of Estonian art and the founding meeting of Eesti Kirjanduse Selts [Estonian Literary Society] ${ }^{34}$ where 
13 Ants Laikmaa (?), A.

Kallas, c. 1906, pastel, 49,5 $x$ $40 \mathrm{~cm}$. The Estonian Literary Museum, Tartu (KM 17). Photo: The Estonian Literary Museum / Alar Madisson.

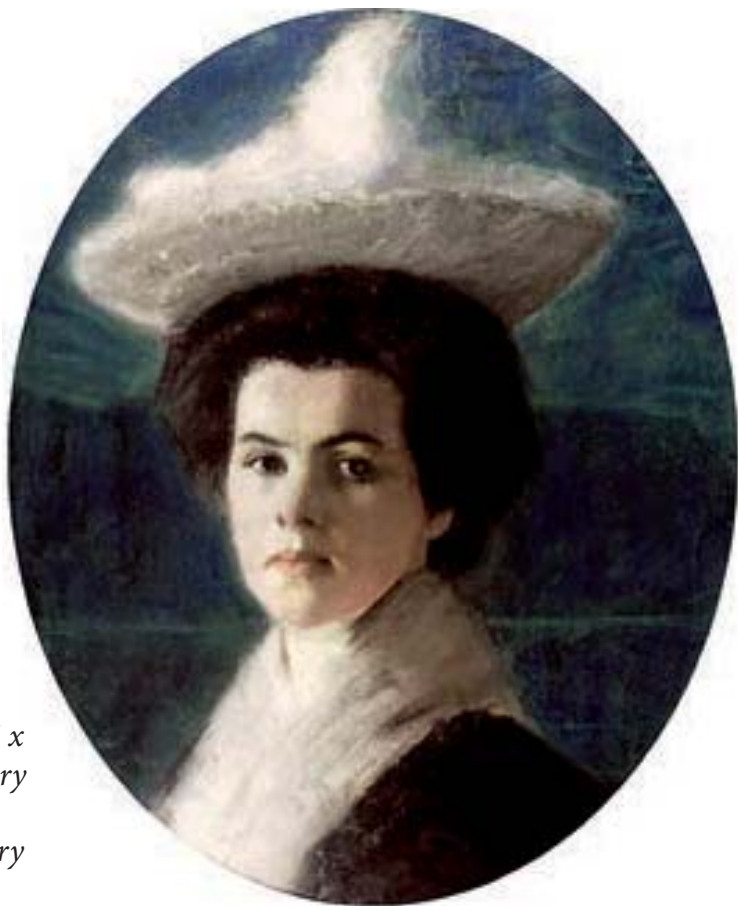

Aino Kallas was also present (Kallas 1988, 267, 395; Nirk 1977, 143). At the beginning of September Kallas informed the painter that the sittings might as well be terminated since she had been unwell so long that the portrait would not turn out as it should (ERA 4060.1.21, 2-10); she lost her son Lembit that summer (Laitinen 1973, 143). The termination was probably a disappointment to Laikmaa who seems to have been impressed by Aino Kallas' exotic presence. As recounted afterwards by Oskar Kallas, Laikmaa had in fact conceded to Gustav Suits that he at first had been so dazzled by her beauty that he was unable to control his brush (Thauvón-Suits 1964, 241). Yet Laikmaa was already an established pastellist at the time, having already portrayed such Estonian cultural figures as the author Marie Under and the composer Miina Härmä, both in 1904.

The paradox that the grand format was chosen precisely at a moment when Kallas was most strongly drawn towards political radicalism (see Laitinen 1973, 88-95) 35 can, perhaps, be understood as a conscious takeover of a powerful formula for a fresh purpose: for showing off the autonomy and subversive energy of a young woman partaking in the formation of a dynamic new cultural field. In a diary entry of 10 December 1917, again most certainly inspired by the course of events in Russia, Kallas reflects favourably but critically on the way that Laikmaa had understood the "dark ground tone of her character". She continues: "As he painted my picture, he had me standing on a red carpet. 'Deep down you are a revolutionary character', he said. Oh yes, deep down indeed, but how many layers of tradition and weakness upon it." (Kallas 1953, 55. $)^{36}$ The diary, of course, is a literary genre with dynamics of its own, and Kallas moreover edited hers for publication decades later. ${ }^{37}$ In an earlier entry, of 21 April 1915, she wrote in a quite different mode: 
Ants Laipman has been here for a couple of days to finish up my picture. He has succeeded in it in bringing out the woman in me, or rather the child in me who never has become a woman. This is exactly how I was eight years ago, quite unawakened, closed into myself, timid, innocent. My countenance has been transformed, but maybe even more my soul. My critical, distrustful scepticism - my intellectual side on the whole, has been missed by him - although it is possible that it was not there yet, not to the same extent anyway. (Kallas 1953, 349.) ${ }^{38}$

Here it is the emancipated woman writer speaking, conscious of the subtlety of the mechanisms of the prevailing gender power order, not the romantic revolutionary inspired by the Russian Revolution.

That her subjectivity circumscribed these somewhat ambivalent motives and contradictory voices - as did the world around her - becomes manifest in various ways. For example, she did not include the Berlin-based painter Arthur Ludwig Ratzka (1869-1958) ${ }^{39}$ in the list of the artists who portrayed her (SKS, Kia) although according to Riitta Kallas $(1989,311)$ he painted a likeness of her at the end of the 1910s. This could either be a Freudian lapse or a conscious choice. Writing in Sweden in the 1940s she did remember him as a "painter of "pretty women" whose "virtuosic but according to the strictest standard slightly too polished portraits" she assumed to be found hanging in many a Helsinki home (Kallas 1944, 82-83). ${ }^{40}$ When the work of this society portraitist was shown in Gösta Stenman's private gallery in Helsinki in December 1920, albeit for a limited audience in a side room, it received altogether smashing criticism. The influential female critic Signe Tandefelt exclaimed in Hufvudstadsbladet, the main Finnish newspaper published in Swedish, that the aesthetics of his portraits equalled that of chocolate boxes. She clearly wished to scandalise the fact that the Finnish sitters who partook in this contemptible "trickery" were prominent representatives of their respective fields. (Tandefelt 2 December 1920.) ${ }^{41}$ While in London during the inter-war years Aino Kallas renewed her acquaintance with the painter's then former wife, the German writer Clara Ratzka, who made a request to translate the English selection of Kallas' writings, The White Ship, into German (Kallas 1944, 83-86; Kallas 1955, 164). Interestingly enough, Clara Ratzka was engaged in the women's movement and generally seen as less politically conservative than her artist husband.

One more mystery remains to be solved: an unsigned, undated portrait - most probably even unfinished - of Aino Kallas at the Estonian Literary Museum (fig. 14). In this oil painting the sitter looks rather submissive and unassuming, presented in a soft Biedermeier or Empire Revival type of aesthetics, ${ }^{42}$ including a blue shawl with floral ornamentation. This is Aino Kallas as the lady of a fine house. This style seems, in visual terms, to refer to the German-speaking ${ }^{43}$ manorial culture of the preceding centuries even though the Kallases probably saw themselves as corresponding to a completely new conception of an - ethnically and linguistically - Estonian and/or Finnish civilisation. The paradox of the traditionalism of the portrait style is that, with his folklorist's background, Oskar Kallas belonged to the generation of Nationalists who took a vital interest in the peasant culture that was seen as more genuinely Estonian than the upper-class culture. In her early production 


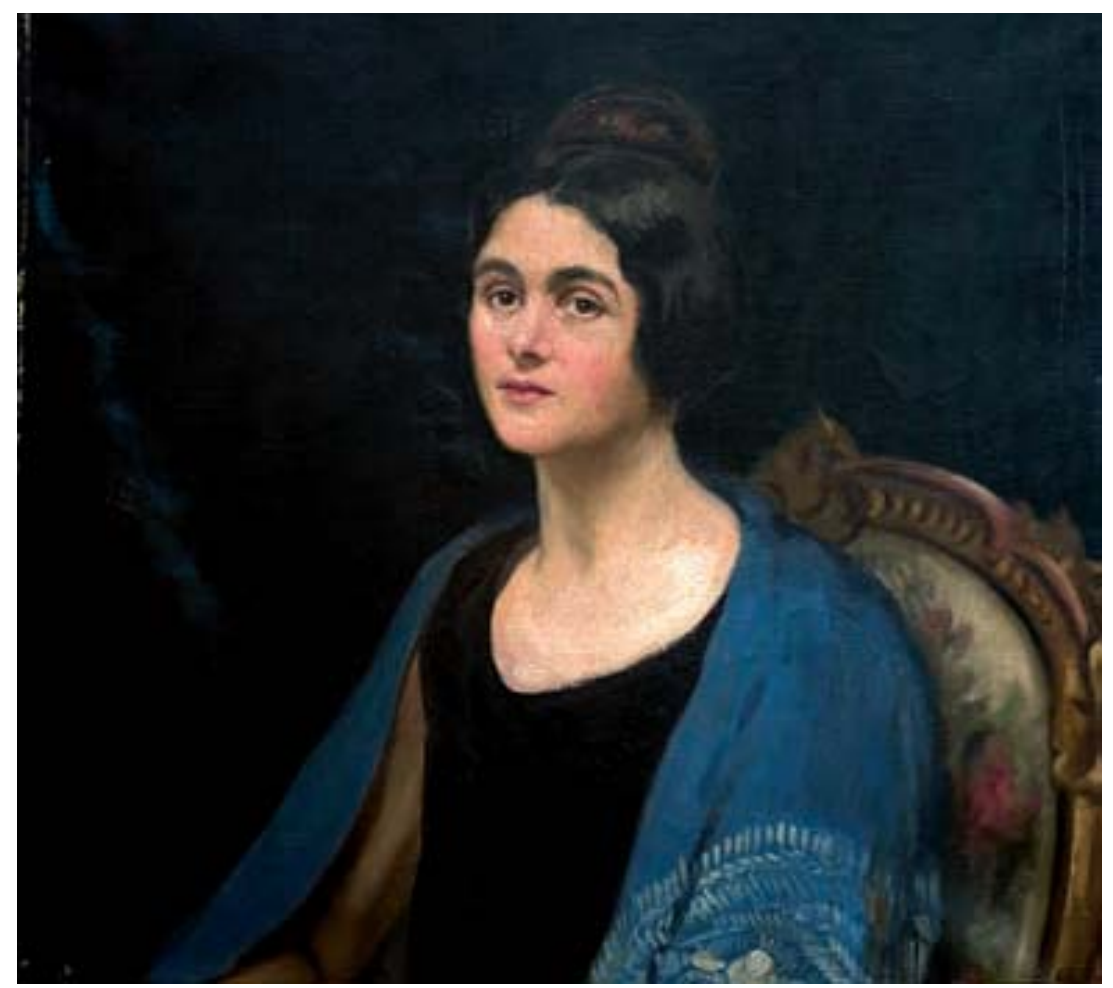

14 René de L'Hôpital (?), A. Kallas, 1920s (?), oil on canvas, 77,5 $\times 77,5 \mathrm{~cm}$. The Estonian Literary Museum, Tartu (KM 16). Photo: The Estonian Literary Museum / Alar Madisson.

Aino Kallas also clearly chose the side of the Estonian peasants rising against the German landowners. On the other hand, from the perspective of the more Modernist Noor-Eesti generation to which Aino Kallas attached herself during their time in Tartu, Oskar Kallas and his circles appeared as conservative. These contradictions unavoidably characterised the life of his wife as well. They were, however, somewhat resolved after Estonia gained independence in 1918. (See e.g., Leskelä-Kärki 2006, 340-341; Olesk 2009, 87-88.)

The portrait of Aino Kallas includes a more contemporary attribute as well: the dark comb crowning her head, clearly the very same one that recurs in her portrait photographs taken in Britain after the Kallases landed there in 1922. In the portrait photos taken in London by Madame Yevonde in 1925 she also wears a very similar sleeveless black dress (fig. 15). In her diary entry of 6 June 1924 there is a mention that a painter called René de L'Hôpital had visited her the previous day and asked her to sit for him (Kallas 1955, 164). At this point, one wonders whether her recurring reference to portraitists' requests was a rhetorical device to ward off accusations of vanity on the part of the sitter. In the case of a society portraitist like L'Hôpital it can only be a question of acquiring commissions. On the other hand, it is possible that through this rhetoric, Kallas wanted to distance herself from the generally unsatisfactory results of the sittings. None of the painted portraits really seemed to correspond with the self-image she wished to convey. 


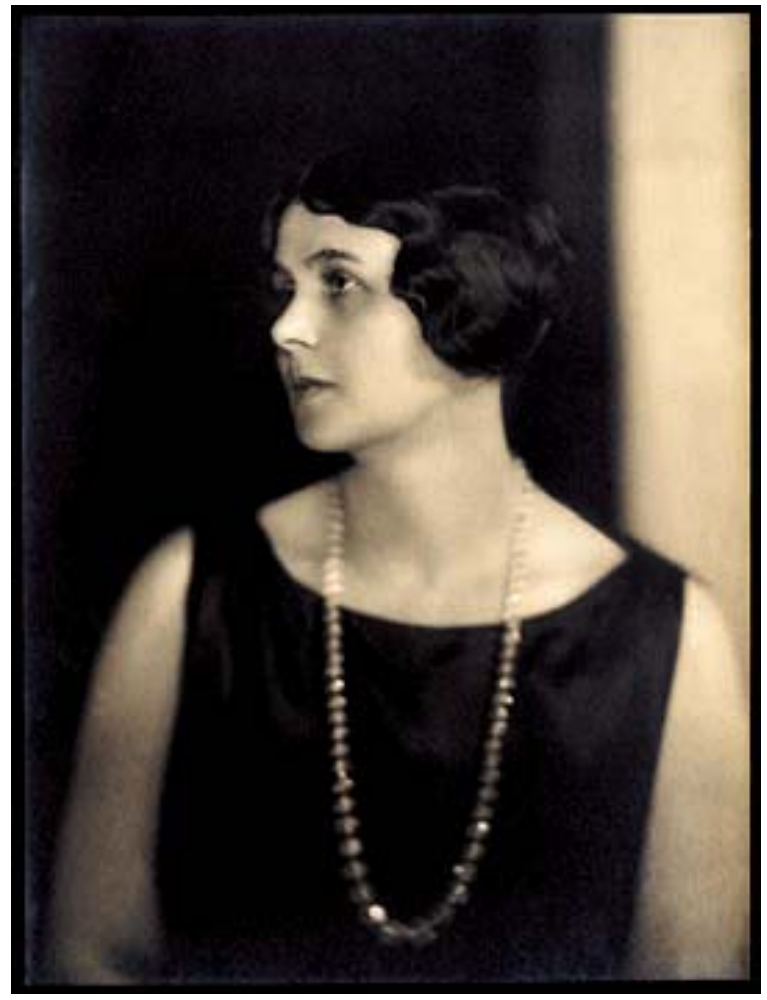

15 Photographic portrait of Aino Kallas, Madame Yevonde, London, 1925, 19,4x $14,5 \mathrm{~cm}$. The archive of Otava, Helsinki. Photo: The archive of Otava.

It seems quite probable that the oil painting at the Estonian Literary Museum that we find difficult to connect with the oeuvre of any Estonian or Finnish painter might have been done by René de L'Hôpital in London (if not by Ratzka in Helsinki). Kallas mentions in her list of portraits (SKS, Kia) that L'Hôpital painted a portrait of her that was left in Tallinn as the family fled the war to Sweden. This painting belongs to the Aino and Oskar Kallas donation made to the Estonian Literary Museum in 1946, based on what was left behind in Tallinn. ${ }^{44}$

On 13 June 1924 Kallas writes in her diary that she is presently sitting for L'Hôpital:

Too late in life, however. I should have been painted at the time when my soul was a sphin $x^{45}$ even to myself and my body that of a young girl, despite my many pregnancies. Now I am content, satisfied and almost 46 years of age and weigh 78 kilos. I am very well aware that I am beautiful but it is a beauty of another kind - - without any yearning or mystery. It is of an abundant and worldly sort. Seeing how L'Hopital had "seen" me made me think all this. A lot of white flesh - - and very little of a soul. (Kallas 1955, 167-168.) ${ }^{46}$

Kallas terms the artist a "society painter" 47 and explains how much easier it was to sit for a photographer, "Mr. Hoppe", on the request of a magazine 
16 Photographic portrait of Aino Kallas, Studio Carl Schulz, Tartu, 1914, 16,3 $x$ 10,6. The Estonian Literary Museum, Tartu (Fk B-85: 156). Photo: The Estonian Literary Museum / Alar Madisson.

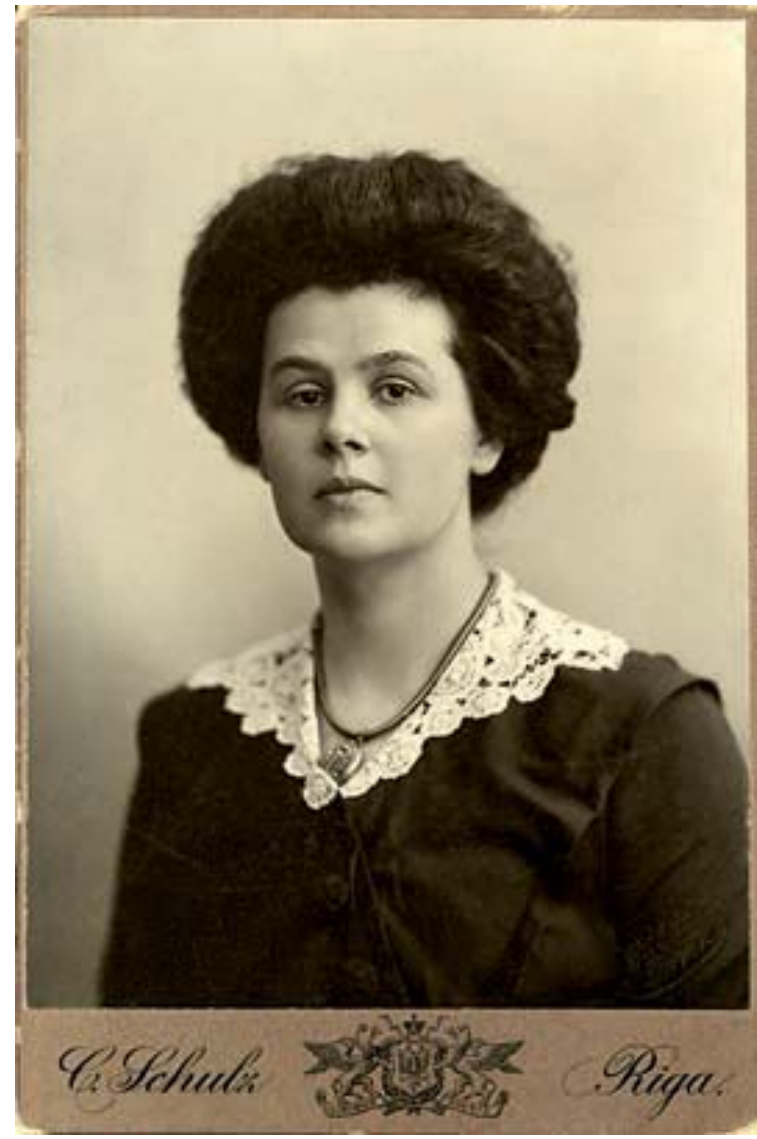

(Kallas 1955, 168). This must have been the studio of E. O. Hoppé, one of the most renowned - and Modernist - portrait photographers of the 1920s; ${ }^{48}$ however, we have not encountered any prints signed with this name.

\section{The art of having her photograph taken}

The Finnish and Estonian press did not at this stage employ quite as renowned photographers as E. O. Hoppé. It seems, rather, that it was very often the sitters themselves who provided the material to be circulated and published. ${ }^{49}$ In the case of a writer, a publishing house may have had author portraits done, too. Whoever was the active party, it is clear that wherever Aino Kallas lived, she always used fine studios - and wanted to control the material used. From Helsinki we know of portraits by the highly professionalised studios of Daniel Nyblin, Atelier Apollo (K. E. Ståhlberg), Atelier Rembrandt, Atelier Universal, Tyyne Savia and Studio Ina Roos (Pauli Huovila). In Tartu and Tallinn she employed the studios of C. Schulz and Peeter Parikas. The prestigious studio of Carl Schulz in Tartu was responsible for the today most canonised 'Art Nouveau' style images (especially that from 1914; fig. 16),,$^{50}$ together with an early portrait of her as a laurel-binder 


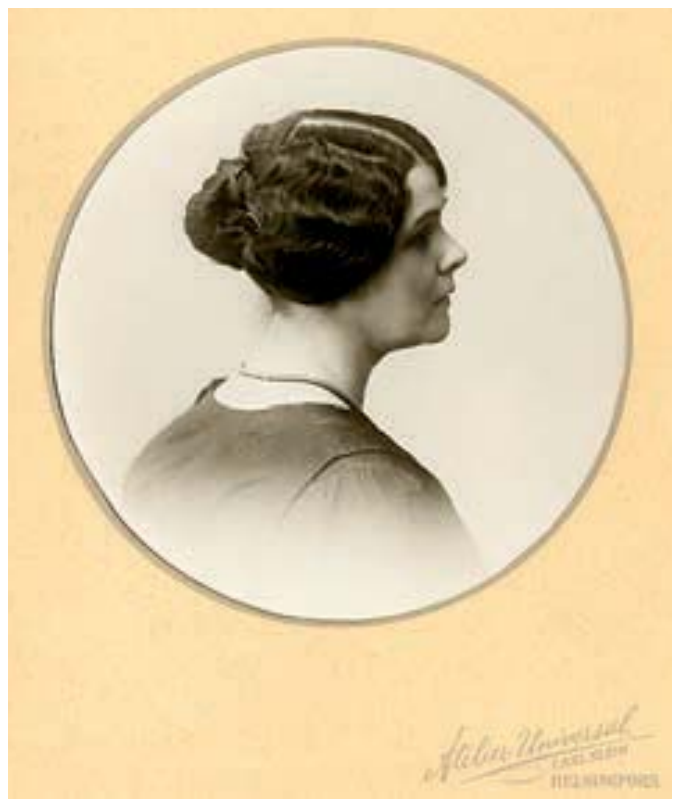

17 Photographic portrait of Aino Kallas, Studio Atelier Universal, Helsinki, 1921, cardboard 25,6 20,4 cm, print 14,4 $\times 12 \mathrm{~cm}$. The Literary Archives of the Finnish Literature Society, Helsinki (Kia 2002:646:1). Photo: The Literary Archives of the Finnish Literature Society.

at the laureation ceremonies of the University of Helsinki in 1897, taken by Daniel Nyblin..$^{51}$ The most circulated inter-war images derive either from the Atelier Rembrandt and the Atelier Universal (fig. 17) studios in Helsinki, dating from a period when Oskar Kallas was stationed as the Estonian Ambassador in Finland between 1918-1922, or from London after 1922.

Salon Strindberg, an art gallery complemented with commerce in reproductions of art and photographic prints, was selling in about 1919 a handsome photograph of Aino Kallas, probably as part of a series of portrait postcards of prominent Finns that was started in 1918 and became very popular (fig. 18)..$^{52}$ The photos for this series were especially commissioned from the Atelier Universal in Helsinki. (Pakkanen 2004, 88-89). In the collections of the Finnish Literature Society there are also two prints that could almost derive from the same sitting but have both been estimated to have been taken in 1921 by two different studios in Helsinki. ${ }^{53}$ From this time on it becomes very difficult to distinguish photographic originals from reproductions. In London Kallas was photographed by the commercial companies Lafayette (1922), ${ }^{54}$ Val L'Estrange (1922), ${ }^{55}$ Swaine (1924), ${ }^{56}$ Hay Wrightson (1923) ${ }^{57}$ and Madame Yevonde (1925). ${ }^{58}$ The first three were granted a royal warrant or were otherwise specialised in court portraiture, as was befitting the spouse of a Minister Plenipotentiary to the Court of St. James. The last two, on their part, were known more as society portraitists with the help of whom Kallas was able to stylise herself as a mondaine New Woman, clad in a black-and-white aesthetics that she also wore when lecturing in public. The image by the Lafayette studio shows her in a ball 


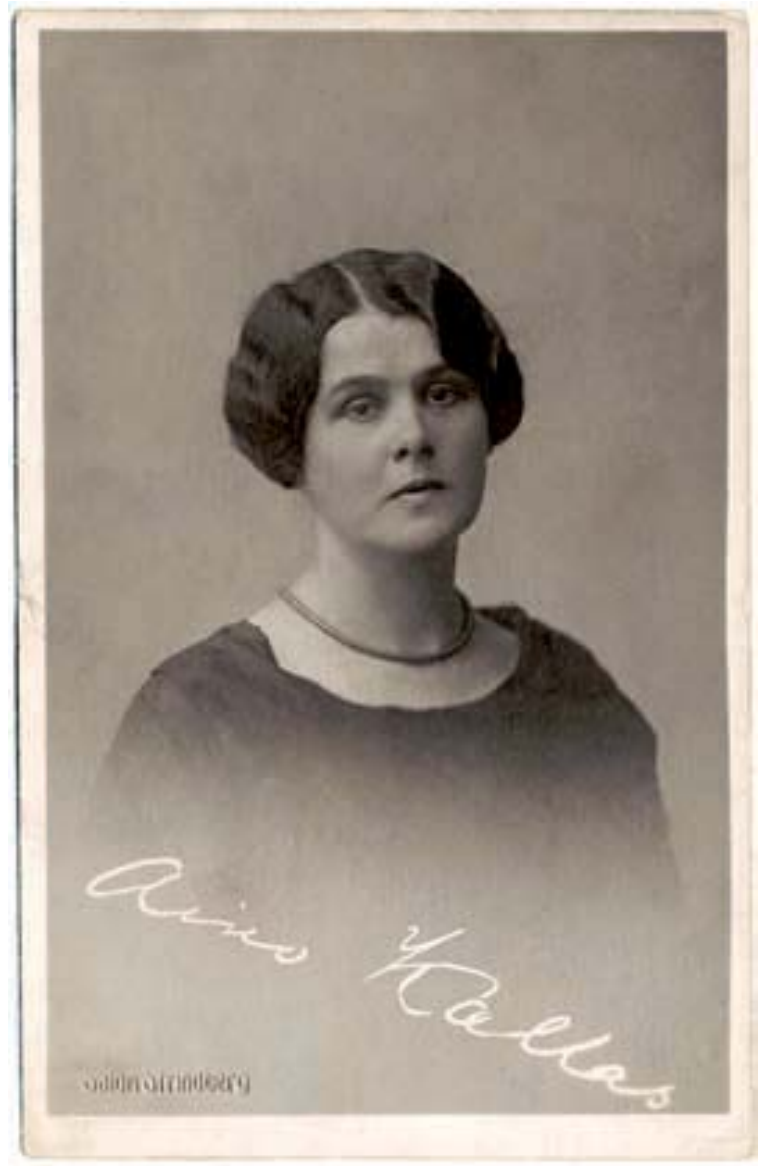

18 Postcard of Aino

Kallas, Salon Strind-

berg, Helsinki, c. 1919, cardboard 13,9 $\times 8,7 \mathrm{~cm}$, print $13 \times 8,1 \mathrm{~cm}$. The archive of Otava, Helsinki. Photo: The archive of Otava.

gown and shawl befitting her years and position, whereas the images by Val L'Estrange and Swaine studios present her in full length Court attire, including a train, a veil and three plumes. Instead of appearing as portraits in the full sense of the term, these images seem to be there to document the unique way of dressing up at the diplomats' receptions that was required by the Court etiquette. In the more republican settings of Finland and Estonia they had a clear curiosity value.

Most of these images have been published on various occasions, beginning with the cover of Suomen Kuvalehti (36/1922), the foremost Finnish illustrated family magazine. On the occasion of her first Court reception, Kallas herself sent in a photograph depicting her in gold brocade, gold lace and tulle to be published. ${ }^{59}$ Her readiness in circulating these images from the Court (e.g., fig. 19) in the Finnish and Estonian press made her, in fact, an easy target for ridicule and moral indignation. It was all too obvious that the required formality - and the good of the young Estonian nation - served as a mere pretext for her to indulge in the luxury and exuberant visuality of it all. In a letter to her Finnish friend Anna-Maria Tallgren she in fact confessed this openly (London 11 June 1922, printed in Vuorikuru 2008, 43): "Shameless me, I forgot everything about democracy and just enjoyed!"60 Another Court photograph, by Hay Wrightson, which had already appeared 


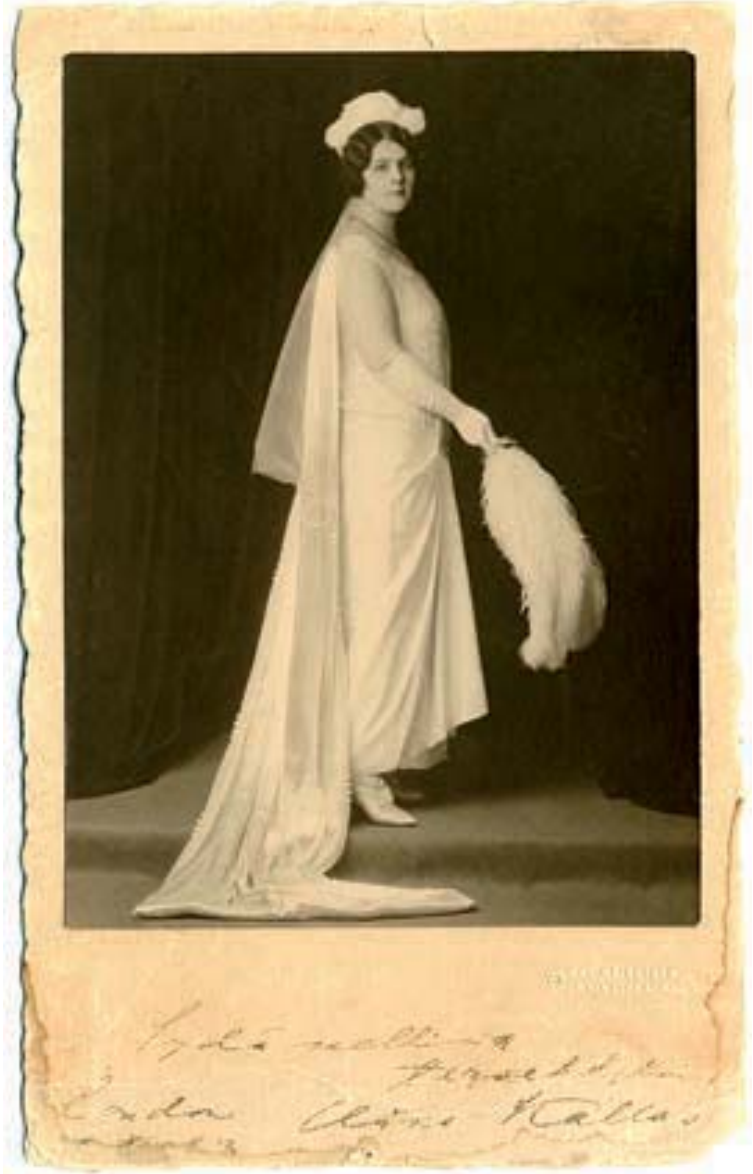

19 Photographic portrait of Aino Kallas, Studio Hay Wrightson, London, 1923, cardboard 20,1 $x$ $12,9 \mathrm{~cm}$, print $15,1 \times 10,9$ $\mathrm{cm}$. The Literary Archives of the Finnish Literature Society, Helsinki (Kia 2005:99:1). Photo: The Literary Archives of the Finnish Literature Society.

on the cover of Odamees (8/1923), was sent in by herself, among other photos, to advertise her literary reading tour in Estonia. In reaction to the vanity professed by this image, her colleague August Alle published a biting article in the newspaper Vaba Maa (13 January 1924), and in another issue of the paper the caricaturist Gori (Georg Tõnisson) commented on the debate in a cartoon that presented Kallas in slightly less unfavourable light (24 January 1924).$^{61}$ She had earlier, too, been pictured in cartoons, ${ }^{62}$ but always rather gently, with a due respect to her courage as a pioneering champion of female intellectualism and her all-but-provincial style. In writing her person was attacked more directly.

Aino Kallas' way of embracing cosmopolitanism - geographical and intellectual mobility - as an aspect of modernity was more congenially received in Finland than in Estonia, perhaps partly because she was not a representative of the Finnish state, and did not in her oeuvre depict Finnish but Estonian ethnicity and mythology (see Haavisto 2009). Kukku Melkas (2006) has convincingly argued for the vital role of the rethinking of "tradition" within modernity and, more specifically, in Kallas' novels of the 1920s. According to Melkas, Kallas did not give up politics after the Noor-Eesti period, but instead transformed her political thinking by envisioning complex and multivocal ethnic and gender identities. ${ }^{63}$ Moreover, both Melkas 
20 Set of photographic proofs of Aino Kallas portraits, Pauli Huovila / Studio Ina Roos, Helsinki 13.10 .1953 , sheet $23,7 \times 17,9 \mathrm{~cm}$. The archive of Otava, Helsinki. Photo: The archive of Otava.
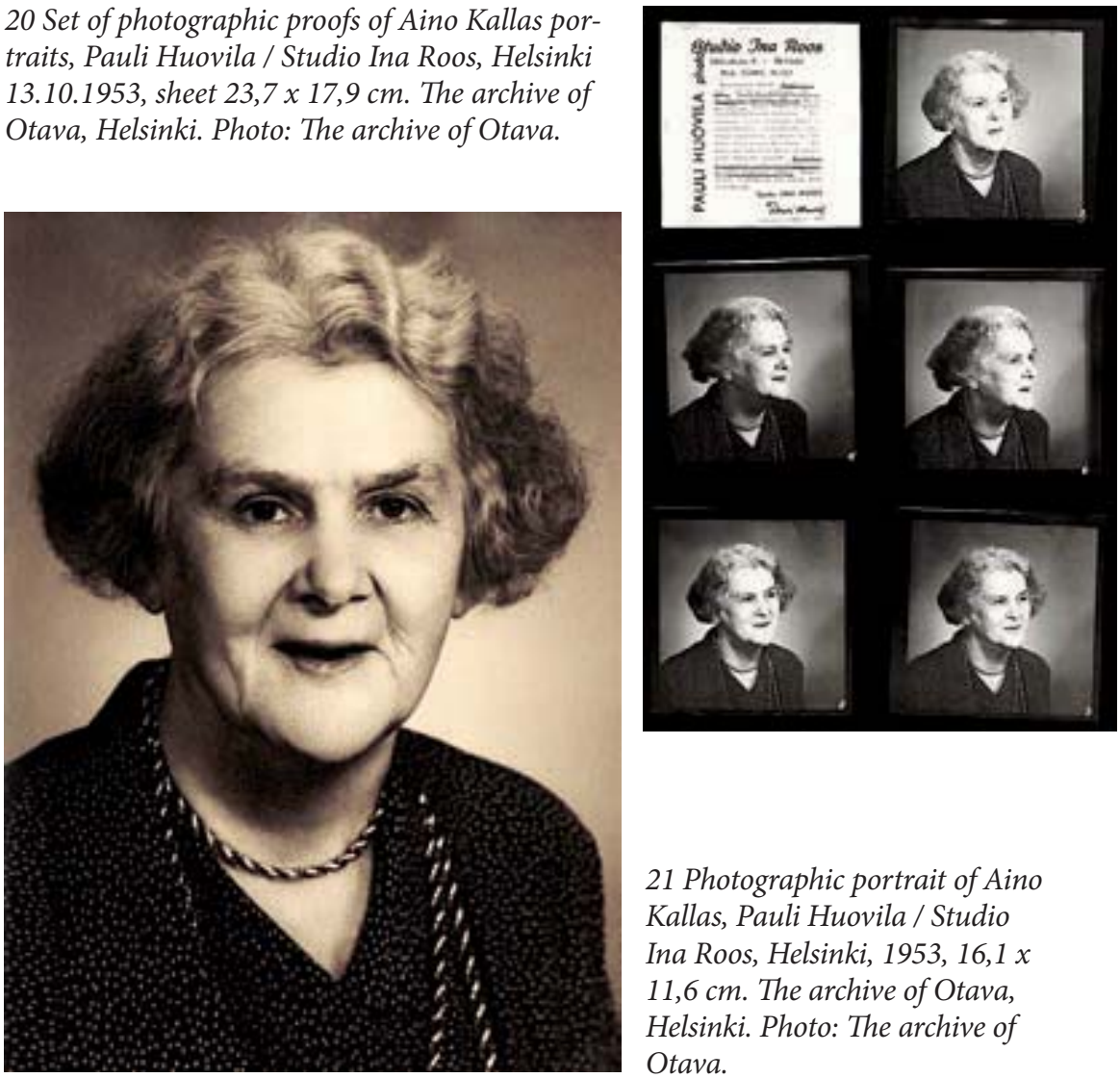

21 Photographic portrait of Aino Kallas, Pauli Huovila / Studio Ina Roos, Helsinki, 1953, 16,1 x $11,6 \mathrm{~cm}$. The archive of Otava, Helsinki. Photo: The archive of Otava.

on the basis of the novels, and Leena Kurvet-Käosaar (2006) through her close analysis of the diaries, underline Kallas' emphatic ways of presenting womanhood as something strongly embodied. It is not so much Kallas' way of just controlling her public image, but her way of demonstrating her enjoyment of her own body as the visual and material site of her existence that can today be seen as a liberated and even subversive gesture. Moreover, it is no longer so impossible to see how a Madame Yevonde would first show an interest in the women's movement and in the next moment start carnevalising and commercialising images of women. However, in Kallas' case, sexual orientation was not something to be played with. ${ }^{64}$

One more interesting axis of difference remains to be noted: that of age. As Aino Kallas was aging, her representations aged with her. She was already in her forties in the early 1920s "glamour" photos. During the 1950s a set of contemporary photographs of a Kallas in her seventies were used for publicity in Finland. Yet today we hardly see them any more, which is a pity since the set of photographs by Pauli Huovila (1916-1969), dated 13 October 1953, is a fine one and lends the Kallas iconography a new perspective (figs $20 \& 21$ ). ${ }^{65}$ The incentive for having these photographs taken was quite clearly to advertise her series of diaries (1952-1956).

With the maturing of Modernism, some important changes had taken place in studio practices and the norms governing the field of photography. 
Studio photographers were now seen as too professional, i.e. commercial, whereas artistic photography was to be found in the camera clubs of amateurs. (Saraste 2004.) Pauli Huovila belonged to the first generation of Finnish portraitists who had been trained as art photographers and were active in camera clubs (Saraste 2004, 78-79). In his studio practice, Huovila needed to combine technical proficiency with the spontaneity of an amateur; Huovila's theory was that taking the wishes of the client too much into account made portraiture dry and conventional (Saraste 2004, 212-213). Although it is a fact that something first felt as unconventional tends to turn into a new convention, in the case of Aino Kallas this new practice produced new kinds of images: less stern and more convivial in nature. We see her countenance from new angles - quite concretely - and her facial gestures seem more communicative. One of the pictures also resulted in a sensitive drawing by the painter Tapani Raittila (1957, Otava, Helsinki) one year after her death. It is this less melancholy and "black and white" image of Aino Kallas that we would like to return as one more variant into her iconography.

Through its exceptional character, this set of photographs also further outlines and nuances her rhetorical choices and circumventions concerning self-presentation. As a female public figure, she needed to maintain a careful balance between a set of identity factors that could turn harmful for her reputation if acted out too blatantly. Her appearance needed to be well groomed and refined in order not to signal sloppiness and availability, while on the other hand norms governing femininity would require a sensuousness that should not equal outright carnality. A dose of mysterious Decadence would be desirable as long as its erotic undercurrent would remain half-veiled in the least. Some ladylike extravagance and cosmopolitan airs were harmlessly entertaining, as long as an overt association with the Swedish and German upper classes of Finland and Estonia, respectively, could be avoided. An independent modern spirit would get sadly compromised by an unreflected traditionalism, but some allegiance to Finno-Ugrian Nationalist causes was to be proclaimed. And, as an aging female star, the risk of appearing callous and too polished - too iconic in fact - should be avoided; a certain softness rounding the features would be in order.

This said, we do not mean to conclude that the management of a public image was only a question of warding off threats and turning down unsatisfactory offers and attempts at representation. It becomes quite clear from Aino Kallas' visual and literary legacy that a great deal of joy and enjoyment was also involved in bodily embracing and articulating a self. 
NOTES

1. Oskar Kallas was stationed in London from 1922-1934. He had married Aino Krohn in 1900 while doing his doctorate in Folkloristics under the supervision of her brother Kaarle Krohn in Helsinki. From 1903 he worked as a teacher and journalist in Tartu and in 1918-1922 he represented - directly after independence - the Republic of Estonia in Finland. After his retirement in 1934 the couple lived first in Tallinn and from 1944 in exile in Stockholm, Sweden, until his death in 1946. In 1953 Aino Kallas returned to Finland.

2. In some of the reproductions, as e.g., on the cover of the anthology Aino Kallas (2009) this black comb disappears in the dark background. This has also happened in a posthumous ink drawing (coloured in watercolours) done after the same photo by the illustrator Ronald Westrén-Doll (1927-1980) in 1959 (The archive of Otava, Helsinki).

3. Cf. Lyytikäinen 1997, 129. For further interpretations of Decadence in Finnish and Estonian literature, see e.g., Lyytikäinen 2003; Parente-Čapková 1998; Hinrikus 2006; Sisask 2009. In the field of visual arts, Decadence is, both as a historical phenomenon and critical category, more pervasive in Estonia than in Finland. In art historical research in Finland the concept is seldom used at all (see Tihinen 2008, 66-67). For a recent elaboration of the notion in the context of the visual arts in continental Europe, see Urban 2006.

4. This happened during the seminar "Aino Kallas kõnetamas oma aega / Aino Kallas puhuttelemassa omaa aikaansa" (Aino Kallas Addressing Her Contemporaries) on 3 October 2008, organised by the Tallinn University and the Estonian Literary Museum. We thank Leena Kurvet-Käosaar for her hospitality and for the idea of writing this article, and Rutt Hinrikus and Vilve Asmer for information on the paintings.

5. One possibility is that the dismay could have been caused by the lighting that underlines the roundedness of her chin; in the published photographs she always holds her chin up. Peeter Parikas wanted to make portrait photography a modern art form in its own right through capturing lively, natural gestures and postures and through underlining by lighting the most characteristic features of each sitter's physiognomy (Teder 1972, 71-73, 83-85). A bit similar pose is found in another photo (by an unidentified studio) from 1932 at the Otava archive that also has the word "no" marked on its backside.

6. At this point we want to mention that in our intellectual vicinity at the Department of Art History at the University of Turku, Finland, M.A. Minna Ijäs is working on a Ph.D. project on the theme of the (co-)authorship of the sitters of portrait photographs, with material from early $20^{\text {th }}$ century Turku. See e.g., Ijäs 2009.

7. [Väinö Hämäläinen pyysi saada maalata minut. Puolen vuoden kuluessa siis kolmatta kertaa mallina, ja paitsi sitä tahtoi Jaan Koort keväällä veistää kuvani, vaikka en suostunut. Rosenthal, Kuutola, Hämäläinen ... Miksi, miksi ei Jan maalannut oikeaa muotokuvaa minusta! Hänelle - ja hänelle yksin olisin voinut näyttää sieluni enkä vain kasvojani! Hän ei sitä tehnyt, ja kaikki muu on yhdentekevää. Itserakkauttani tietysti hivelee tämä "maalauksellisuus", mutta samalla on jokainen mallina istuminen minulle katkeransuolainen muisto.] Translations of citations from Finnish by Tutta Palin. The word "painterly" (maalauksellinen) here probably equals such attributes as 'picturesque', or 'photogenic', but with slightly more of a "high-art" connotation.

8. The German orthography (also as "Jan Rozentals") is commonly used in other Finnish and Estonian texts of the era as well. In Finland this may have been partly due to the fact that "Jan Rosenthal" sits well in the mouth of someone learned in Swedish (another Germanic language, unlike Latvian). 
9. Anto Leikola (2006: 76-77), a descendant of the Rozentāls-Forssell family, has explicitly remarked how cruelly the artist's spouse Elli Rozentāls (b. Forssell), a childhood acquaintance of Aino Kallas, was forced to witness their romance (cf. also Kallas 1989, 274). His interpretation is mainly based on Kallas' diaries.

10. In her "wandering guestbook" commented and edited by herself (i.e., half a diary) she writes on 28 February 1950: "Judge [Aulis] Rydman brought here the picture which was painted of me by Jan Rozentals in Kulosaari in the summer of 1916 - and remained unfinished. However, still prior to his death [which was to happen within a few months], he had replaced my head with the classical profile of his family's Finnish maid. The whereabouts of the picture was long unknown and I already thought it lost forever. Rydman refuses to give the picture to me, but Martta Helminen has promised to copy it for me." [Tuomari Rydman toi tänne taulun, jonka Jan Rozentals maalasi minusta Kulosaaressa kesällä 1916 - taulun jäädessä keskeneräiseksi. Ennen kuolemaansa hän kuitenkin ehti asettaa minun pääni sijalle perheen suomalaisen kotiapulaisen klassisen profilin. Taulu on ollut kauan kadoksissa, ja luulin sen jo joutuneen hukkaan. Rydman ei suostu luovuttamaan taulua, mutta Martta Helminen lupasi sen kopioida minua varten.] (Kallas 1957, 36). The painting is still owned by the Rydman family and the copy/variation by the Kallas family. In Kallas' diary entry on 22 February 1917 it already reads: "This is how [warmly] I still think of him! I would want to purchase my picture, as ruined as it is." [Näin minä siis yhä ajattelen häntä! Tahtoisin ostaa oman kuvani, niin pilalla kuin se onkin.] (Kallas 1954, 61.) One feels tempted to draw the conclusion that Rozentāls' widow was not willing to sell the painting to her.

11. The photograph used by Helminen was most likely one taken by Madame Yevonde in 1925 (see further below).

12. [... olin hänelle tällä hetkellä yksinomaan vain malli.] The Finnish word malli makes no distinction between a 'sitter' and a 'model' but our interpretation is that she here refers to the latter sense of the term.

13. [... klassillisen puhtaat piirteet.] The comparison between "Finnish" and "Hellenic" 'races' was surprisingly common at the time, mainly in the context of the oeuvre of the male sculptor Wäinö Aaltonen whom Kallas at least later on mentioned in a very favourable light (see Kallas 1957, 36). It is interesting, too, that for example in a letter written to Anna-Maria Tallgren a few years after the Rozentāls incident, Kallas refers to her own "restless racial heritage" [rauhattomaan rotuperintööni] (Helsinki, 21 December 1920, printed in Vuorikuru 2008, 35). This, perhaps, means her Fennoman father's background in a German family from St. Petersburg (see Laitinen 1973, 23-25). This kind of a romantic idea of both physical and intellectual nomadism (cf. also "my nomad's blood" in Kallas 1957, 106) was well in accordance with the ideology of the Noor-Eesti group that Kallas had become part of (Laitinen 1973, 123). In this context, and in the more general cultural imagination of the time, the notion of 'Classical' (pure/sound) and 'Decadent' (hybrid/morbid) are often used contrastively.

14. For an illustration of the painting, see Mela 2006, 114. The same head position suits much better a bather figure, or a woman at her toilette, titled Semi-nude (Elly, private coll.) from the same year 1916. This one, however, seems to have been modelled after Elli Rozentāls (at least the face). For a reproduction, see Pujāte 1990, nr. 199.

15. [Sieluni on hekumallinen ja kuuma, ainoastaan ruumiini ei koskaan ole tuntenut hekumaa. Eilen oli minulla suuri nautinto: Heti kun Jan Rosenthal tuli sisään, huomasin, että maalari, taiteilija hänessä heräsi. Ylläni oli valkea musliinileninki, hiukset sykeröinä korvilla. ... Jan antoi tyttärensä juosta tuomaan erilaisia kirjavia huiveja, joilla hän draperoi minua. "En koskaan käytä kirjavaa", sanoin, "se ei sovi sieluuni, käyn aina vain mustissa ja valkoisissa". ”Ei, teillä pitää olla jokin vastavaikutus, niin että kaikki teidän hienot, hennot värinne pääsisivät oikeuksiinsa."]

16. [... käsivarret paljaina, oikeat tai - miksikä ei! - keinotekoiset helmiketjut kaulassa, 
sellaisina kun he liikkuivat riigivaneman, ulkoministerin ja vieraitten valtojen lähetystöjen vastaanotoissa.]

17. [Ei "silkkimustaa" enää ole muuta kuin muistoissa vain, kyllä minä olen rehellisesti ja värjäämättä hiirenharmaa.]

18. Cf. also the very mondaine en face portrait of a half-reclining dark-haired lady from the year 1910 (Woman in Black) who wears a black dress and a long chain around her neck, much reminiscent of the style later favoured by Kallas. For a reproduction, see Janis Rozentāls 1866-1916 1966, 101.

19. See e.g., Aino Kallas' letter to Anna-Maria Tallgren, 10 February 1932, printed in Vuorikuru 2008, 149.

20. The villa $\mathrm{Nr} 13$, also called Vårberga, later burned down and has been replaced by a 1990s villa.

21. On the side of the variation on the Rozentāls painting, she mentions one portrait "in bust length" and another one in "full length". The latter one is not known; as she was not a specialist in fine art, it is also difficult to know what exactly is meant by a "full-length portrait".

22. A black-and-white reproduction of a quite different portrait sketch, albeit also in the bust format, was published in the autumn 1949 in an interview with Juha Nevalainen in the newspaper Helsingin Sanomat (Nevalainen 30 October 1949). In this sketch the sitter's attire is much less mondaine and even her hair looks grayer under the elegant headgear reminiscent of a mourning hat (although Aino Kallas had been widowed already three years earlier). It can anyhow be characterised as a sympathetic depiction of a friendly elderly lady - and as such not part of the canonical Kallas iconography. In the later painting at Otava the sitter looks distinctly younger. It may also be worth pointing out that at the Finnish Literature Society (SKS, Kia) there exists - in two copies - an undated photograph by the studio of Tyyne Savia in Helsinki which combines features from both of these pictures (a mourning hat and a fur collar). This small photograph has the characteristics of a passport photo. (For information on Tyyne Savia who opened her Helsinki studio in 1917, see e.g., Savia, Tyyne Elisabeth s.a.) Kallas also wears very similar attire in a black-and-white photograph documenting a party thrown in Tartu in 1938 on the occasion of her $60^{\text {th }}$ birthday (TKM-B85-169). The photo is published in Kallas 1989, photo appendix.

23. Art historian Margareta Willner-Rönnholm has described how Snellman-Kaila who was six years senior to her husband was belittled beside him - as just another high-society lady - even in visual representations such as photographs (WillnerRönnholm 2004, 69-71).

24. [Jan Rosenthal olisi voinut minut maalata; hän tunsi minut.] [... sen ilme on minulle vieras ja kai ulkoinen.]

25. Vilve Asmer's email reply to Kai Stahl on 13 August 2009.

26. Email reply to Kai Stahl on 3 September 2009. See also Räty 1989.

27. Arthur Valdes was a contrivance by the author Friedebert Tuglas and the art critic Hanno Kompus (Pihlak 1979, 117). A reproduction of the postcard image can be found in Laitinen 1973, photo appendix.

28. An English translation appeared in 1921 as The Book of Masks.

29. Suits was one of the Estonian translators of the works of Aino Kallas, Eino Leino and Juhani Aho.

30. In 1912 Mägi also illustrated Kallas' book Lähtevien laivojen kaupunki [City of Departing Ships] and the Estonian edition of Eino Leino’s Päivä Helsingissä [A Day in Helsinki] (Pihlak 1979, 71).

31. The first lead to this drawing was a photographic reproduction among art historian Evi Pihlak's remaining study material (private coll., Tallinn). This is presumably a copy of a photograph that used to belong to the collections of the Institute of History at Tallinn University but is not there today. We want to thank researcher 
Helen Bome from the Department of Art History at the Tallinn University for this information, and the head of the Prints and Drawings Collection, Anne Untera from the Art Museum of Estonia for detecting the original drawing at the depositories of the museum with the help of this reproduction.

32. According to her daughter, the literary historian Livia Viitol, the artist had at her disposal especially Kallas' memoirs of Oskar Kallas, Elämäntoveri [Life's Companion], and some early photographs of Kallas. On the cover of the mentioned book is a photograph of 19-year-old Aino Kallas as a laurel-binder at the laureation ceremonies of the University of Helsinki in 1897. The somewhat different plaster and bronze versions of the portrait sculpture are still in the artist's family. (Livia Viitol's email replies to Kai Stahl on 7 and 14 August 2009. For Viitol as an artist, see Kivimäe 2000.)

33. Boubong was an Alsacienne schooled in Stuttgart and Munich, exhibiting mostly in Germany and Austria (Munich, Berlin, Vienna, Düsseldorf). See Vollmer 1910.

34. The exhibition and the meeting took place at the just inaugurated Vanemuise theatre and concert hall, designed by the Finnish architect Armas Lindgren. The Estonian Literary Society is still based in Tartu, at Vanemuise 19.

35. It may be mentioned that the novella Bernhard Riives is based on the tragic fate of Laikmaa's brother Bernhard Laipman, a peasant who was shot and killed in January 1906 after revolting against the landowners (Laitinen 1973, 93-94).

36. [... aavistaneeko tällä monikaan minun olentoni tummaa pohjasäveltä? Laipman sen käsitti. Kun hän maalasi kuvani, hän pani minut punaiselle matolle seisomaan. "Pohjalta te olette revolutsionääri luonne", hän sanoi. Niinpä niin, pohjalta, mutta kuinka paljon traditsioonien ja heikkouden kudosta onkaan sen yllä!] See also the entry on 6 December 1908: “Laipman said to me: 'You are proud!' I replied: But humble in front of every assertion of power" [Laipman sanoi minulle: "Te olette ylpeä!" Minä vastasin: "Mutta jokaisen voimanosoituksen edessä nöyrä!"] (Kallas 1953, 114).

37. For Kallas' diaries, see e.g., Kurvet-Käosaar 2006, esp. p. 66.

38. [Ants Laipman on ollut tälllä pari päivää kuvaani viimeistelemässä. Hän on saanut siinä esiin naisen minussa tai pikemmin lapsen, josta ei koskaan ole tullut naista. Juuri sellainen olin kahdeksan vuotta sitten, aivan heräämätön, suljettu, arka, viaton. Kasvoni ovat muuttuneet, mutta sieluni ehkä vielä enemmän. Minun arvostelevaa, epäilevää skeptillisyyttäni - ylipäänsä älyllistä puolta hän sen sijaan ei ole saanut ilmi - ehkä sitä ei silloin ollutkaan, ainakaan samassa määrin.]

39. Ratzka was a painter and engraver born in the village of Andrejevá in present-day Slovakia. He studied in Vienna and Munich and worked in Berlin from 1901 and in New York from 1923 (see Bénézit 2006b). According to Bénézit 2006 he is said to be a Slovak; in earlier sources he was always a Hungarian.

40. [Hän oli lyhyenä Suomen oleskeluaikanaan jo ehtinyt saavuttaa maineen "kauniitten naisten" muotokuvamaalarina, ja uskon hänen taiturillisia, vaikkapa ehkä ankarimman mittapuun mukaan hieman liian silostettuja muotokuviaan riippuvan monenkin helsinkiläiskodin seinällä.]

41. This is not idiosyncratic to the critic but a rather standard reaction to a portrait practice that the cultural elite judged compromisingly commercialised (see Palin 2007, 33-35).

42. It must be noted, however, that the chair on which she is seated, should rather be characterised as Rococo Revival.

43. Or, in the case of Finland, Swedish-speaking.

44. The problem with this attribution is that Kallas claims that the portrait was made in full length (kokovartalokuva). It, however, seems possible that Kallas would have been careless enough to characterise this half-length portrait as full-length; it is more than a mere bust anyhow, and could also have been cut at some point.

45. For the sphinx as a version of the femme fatale and an important symbol for free- 
dom and creativity in Symbolist and Decadent literature, see Lyytikäinen 1997; Lyytikäinen 2003, 16.

46. [Liika myöhään tosin. Minut olisi pitänyt maalata silloin, kun sieluni oli sfinksi minulle itsellenikin ja ruumiini monista lapsistani huolimatta nuoren tytön. Nyt olen tyytyväinen, tyydytetty ja kohta 46 vuoden vanha ja painan 78 kiloa. Tiedän vallan hyvin, että olen kaunis, mutta se on toista lajia kauneutta - siinä ei ole enää kaipausta eikä salaisuutta. Se on rehevää ja maallista. Ajattelin tätä kaikkea, kun näin, miten L'Hôpital oli minut "nähnyt". Paljon valkeaa lihaa - ja vähän sielua.]

47. At another time, Kallas mentions him as an example of the descendants of French Huguenots in Britain, more precisely a descendant of the Duke of Guise (Kallas 1944, 46). It is true that L'Hôpital was known as a society portraitist as well as an illustrator. According to the Benezit Dictionary of Artists (Bénézit 2006a), Count René Le Brun de L'Hôpital was the son of the $6^{\text {th }}$ Duc de Vitry, trained at the Royal Academy and employed as a portrait painter by members of the British nobility and Pope Leo XIII, and as an illustrator by the Encyclopaedia Britannica.

48. For the German-born photographer Emil Otto Hoppé who opened a studio in London in 1907, see e.g., Hoppé, Emil Otto, 1878-1972, Photographer and Writer 2004.

49. For Finland, see Leino-Kaukiainen 1992. It was only in the 1950s when photojournalism really started to flourish in the form of illustrated reportages etc. See also Henna Haavisto's $(2009,166)$ note on the fact that almost all of the pictures published of Kallas were close-ups.

50. On the cardboard frames of the Schulz studio it reads Riga but the photos themselves bear a relief stamp from the studio in Tartu (see e.g., a copy of the portrait from 1914 at the The Manual Department of Archival Library of Estonian Literary Museum, Tartu, KM B-85:156). It is most probable that Aino Kallas was photographed, in 1908 and 1909 with her children, by Carl Schulz Junior in Tartu (cf. Asmer 1998; Teder 1972, 33-34). According to one cardboard frame (SKS, Kia 2002:672:1-2) C. Schulz - - in two generations - - had activity in "Wien, Paris, Moscou, Peterburg, Riga, Milan, Dorpat, Wenden". Most of the photographers active in Estonia were German or Russian and often worked at least in the nearest big cities, such as Riga, Tallinn, Moscow and Helsinki. The cardboard materials may have been older than the photos themselves. (Email reply by Mall Parmas from the photo history collections of Tallinn City Museum to Kai Stahl on 31 August 2009).

51. Leena Kurvet-Käosaar $(2006,49-50)$ has analysed this photograph as an example of the pleasure taken by young Aino Krohn in corresponding to the norms of female beauty.

52. Copies of a photograph mounted on thick cardboard or printed on a postcard can be found e.g., in the archive of Otava in Helsinki and at the Estonian Literary Museum (KM) in Tartu. The signature of the writer has been printed on white on the photograph.

53. See the very "artistic" prints, one hand-signed at the Atelier Rembrandt (SKS, Kia 2002:645:1), and another mounted in a handsome cardboard frame with the name of Atelier Universal (SKS, Kia 2002:646:1). For both of the commercial studios, in 1921 owned by Swedish entrepreneurs, see e.g., Salo 2005.

54 . For the company founded in Dublin by James Lafayette, granted a royal warrant and practising in London between 1897-1952, see A Brief History of the Lafayette Photographic Studios s.a. For Kallas photos, see e.g., the archive of Otava; KM D-85:19.

55. Riitta Kallas (1989, photo appendix) has interpreted the photographer's hand-written signature as Val L'Estrange, 67, Knightsbridge. We have not so far been able to track down a studio with this name. Original, signed photos can be found in the archive of Otava.

56. For F. A. Swaine, a commercial photographer active in London around 1919-1938, 
see Swaine, F A, fl 1919-1938, Photographer 2004. For a Kallas photo, see e.g., SKS, Kia 2002:662:1.

57. For Hay Wrightson (1874-1949) who photographed royalty in the 1920s, see Wrightson, Hay, fl 1920-1929, Photographer 2004. For Kallas photos, see the archive of Otava; KM A31:83, A-85:274, A-2:619, D-37:287; SKS, Kia 2005:99:1.

58. Yevonde Cumbers Middleton (1893-1975) was a doyenne of British society portrait photographers, active 1914-1975, and a pioneer in photographic techniques, such as solarisation and - from the 1930s - the Vivex colour process. She used the professional name Madame Yevonde, and moved to larger premises in London in 1921, turning increasingly to commercial work from 1925 onwards. See Gibson \& Roberts 1990.

59. See Aino Kallas' letter to Helmi Krohn, London 16 July 1922, printed in Kallas 1989, 52.

60. [Häpeä sanoa, unohdin kaiken kansanvaltaisuuden, ja vain nautin!]

61. For the whole incident, see e.g., Kallas 1946, 160-164; Kallas 1989, 294-295. Georg Tõnisson (1894-1944) changed his name into Vello Agori in 1935.

62. See e.g., Laitinen 1973, photo appendix.

63. See e.g., Leppänen 2009 for how, on another level, women's organisations were at the same time combatting the question of intersecting gender and national identities.

64. In her memoirs of her time in London Kallas recounts having met Radclyffe Hall at the PEN Club and having gained access to her banned lesbian novel The Well of Loneliness (1928). In her characteristic style Kallas very carefully describes the looks of the "homosexual woman" [homoseksuaaleja naisia] as she frankly calls her. The novel she evaluates as "an honest, unembellished book, well written, although instinctively repulsive to every sexually normal individual" [... rehellinen, kaunistelematon kirja, hyvin kirjoitettu, vaikka jokaiselle sukupuolellisesti normaalille yksilölle vaistomaisesti vastenmielinen] (Kallas 1944, 163). In terms of sexual orientation, Madame Yevonde's 1930s heavily staged colour photographs where aristocratic women pose as "Goddesses" in the $18^{\text {th }}$ century bucolic or turnof-the-century Decadent manner, are truly baffling.

65. The original proofs as well as several signed prints are preserved in the archive of Otava. At this time Huovila was still using the studio label "Ina Roos" which he had purchased when starting his own studio in 1942. For Huovila, see e.g., Honkonen 2001. 


\section{References}

\section{Unpublished sources}

The archive of the publishing house Otava, Helsinki

Kallas, Aino (folder)

The Literary Archives of the Finnish Literature Society (Suomalaisen Kirjallisuuden Seuran kirjallisuusarkisto, SKS, Kia), Helsinki

Kallas, Aino: "Portraits of Aino Kallas" (undated list of portraits made of herself) (box 4:2)

The Manual Department of Archival Library of Estonian Literary Museum (KM), Tartu

Kallas, Aino

The State Archives of Estonia (Eesti Riigiarhiiv, ERA), Tallinn

Laikmaa, Ants - maalikunstnik. Kirjad Aino Kaldalt, Aino Tammelt, Kristjan Raualt, Friedebert Tuglaselt, Natalie Mey'lt jt ning Marie Underi luuletus [Laikmaa, Ants - A Painter. Letters from Aino Kallas, Aino Tamme, Kristjan Raud, Friedebert Tuglas, Natalie Mey et al. and a poem by Marie Under] (original manuscript) (ERA 4060.1.21)

University of Jyväskylä, Department of Art History

Räty, Leena 1989: Kalle Kuutola suomalaisen kubismin edustajana. [Kalle Kuutola as an Exponent of Finnish Cubism.] Unpublished Master's thesis

Asmer, Vilve, email to Kai Stahl, 13 August 2009

Parmas, Mall, email to Kai Stahl, 31 August 2009

Räty, Leena, emails to Kai Stahl, 31 August - 4 September 2009

Viitol, Livia, emails to Kai Stahl, 7 August 2009 and 14 August 2009

\section{Published sources and research literature}

Alle, August 13 January 1924: Jaanalinnu sulgedega. Kirjanduslik följeton. [Plumed. A Literary Feuilleton.] Vaba Maa 10.

[Bénézit, Emmanuel] 2006: L'Hôpital, René Le Brun de (Count). In: Benezit Dictionary of Artists 8. Paris: Gründ. (2006a)

[Bénézit, Emmanuel] 2006: Ratzka, Arthur Ludwig. In: Benezit Dictionary of Artists 11. Paris: Gründ. (2006b)

Gibson, Robin \& Roberts, Pamela 1990: Madame Yevonde: Colour, Fantasy and Myth. London: National Portrait Gallery.

Gori [Georg Tõnisson] 24 January 1924: Mõndasugust. [Sorts of Things.] Vaba Maa 19.

Haavisto, Henna 2009: "Kirjallisuutemme pikkuhelmiä". Aino Kallas ja modernin naiskirjailijan ongelmallinen julkisuuskuva. ["Small Pearls of Our Literature". Aino Kallas and the Problematic Public Image of the Modern Woman Writer.] In: Maarit Leskelä-Kärki, Kukku Melkas \& Ritva Hapuli (eds), Aino Kallas. Tulkintoja elämästä ja tuotannosta. [Aino Kallas. Interpretations of Life and Works.] Helsinki: BTJ Kustannus.

Hinnov, Virve 1972: Esimesed Eesti kunstinäitused. [The First Art Exhibitons in Estonia.] In: Tartu Riikliku Kunstimuuseumi almanahh III. [Almanac of The National Art Museum of Tartu III.] Tartu: Tartu Riiklik Kunstimuuseum.

Hinrikus, Mirjam 2006: Spleen the Estonian Way. Estonian Literary Decadence in J. Randvere's Ruth (1909), Friedebert Tuglas' Felix Ormusson (1915), and Anton Hansen Tammsaare's Novellas Noored hinged (1909) and Kärbes (1917). Interlitteraria 11. 
Ijäs, Minna 2009: Esittää ja esittäytyä. Ihmisiä valokuvamuotokuvissa 1920-luvulla. [To Perform and to Present Oneself. People in Photographic Portraits of the 1920s.] In: Taina Erävaara \& Ilona Tanskanen (eds), Välissä. Valokuvat ymmärtämisen välineinä. [In Between. Photographs as a Medium of Understanding.] Turun ammattikorkeakoulun oppimateriaaleja 43. [Course Materials of the Turku University of Applied Sciences 43.] Turku: Turun ammattikorkeakoulu \& Valokuvakeskus Peri.

Janis Rozentāls 1866-1916 1966. Text by Miķelis Ivanovs. Rìga: Liesma.

Kallas, Aino 1944: Löytöretkillä Lontoossa. Kaksitoista vuotta Viron Lontoon-lähetystössä vuosina 1922-1934. Muistelmia Englannista, Amerikasta ja Hollannista. [Exploring London. Twelve Years in the Estonian Embassy in London During the Years 1922-1934. Memoirs from England, America and Holland.] Helsinki: Otava.

Kallas, Aino 1946: Uusia kanssavaeltajia ja ohikulkijoita. Muistoja ja muotokuvia. [New Travelling Companions and Passers-By. Memories and Portraits.] Helsinki: Otava.

Kallas, Aino 1947: Kolmas saattue kanssavaeltajia ja ohikulkijoita. Muistoja ja muotokuvia. [Third Group of Travelling Companions and Passers-By. Memories and Portraits.] Helsinki: Otava.

Kallas, Aino 1952: Päiväkirja vuosilta 1897-1906. [Diary from the Years 1897-1906]. Helsinki: Otava.

Kallas, Aino 1953: Päiväkirja vuosilta 1907-1915. [Diary from the Years 1907-1915]. Helsinki: Otava.

Kallas, Aino 1954: Päiväkirja vuosilta 1916-1921. [Diary from the Years 1916-1921]. Helsinki: Otava.

Kallas, Aino 1955: Päiväkirja vuosilta 1922-1926. [Diary from the Years 1922-1926]. Helsinki: Otava.

Kallas, Aino 1957: Vaeltava vieraskirja vuosilta 1946-1956. [Wandering Guest Book from the Years 1946-1956.] Helsinki: Otava.

Kallas, Riitta (ed.) 1988: Kolme naista, kolme kohtaloa. Aino Kallaksen kirjeenvaihtoa Ilona Jalavan ja Helmi Krohnin kanssa vuosina 1884-1913. [Three Women, Three Destinies. Aino Kallas' Correspondence with Ilona Jalava and Helmi Krohn from the Years 1884-1913.] Helsinki: Suomalaisen Kirjallisuuden Seura.

Kallas, Riitta (ed.) 1989: Kolme naista, kolme kohtaloa. Aino Kallaksen kirjeenvaihtoa Ilona Jalavan ja Helmi Krohnin kanssa vuosina 1914-1955. [Three Women, Three Destinies. Aino Kallas' Correspondence with Ilona Jalava and Helmi Krohn from the Years 1914-1955.] Helsinki: Suomalaisen Kirjallisuuden Seura.

Kompus. J. [Hanno] 1917: Eesti kujutav kunst 1916. [Art in Estonia in the Year 1916.] In: Eesti Kirjanduse Seltsi aastaraamat IX (1916). [Yearbook of the Estonian Literary Society IX (1916).] Tartu: Eesti Kirjanduse Selts.

Kurvet-Käosaar, Leena 2006: Embodied Subjectivity in the Diaries of Virginia Woolf, Aino Kallas and Anaïs Nin. Dissertationes litterarum et contemplationis comparativae Universitatis Tartuensis 6. Tartu: Tartu University Press.

Laitinen, Kai 1973: Aino Kallas 1897-1921. Tutkimus hänen tuotantonsa päälinjoista ja taustasta. [Aino Kallas 1897-1921. A Study of the Main Characteristics and Background of Her Work.] Helsinki: Otava.

Leikola, Anto 2006: Janis Rozentāls ja hänen kaksi kotimaataan. [Janis Rozentāls and His Two Home Countries.] In: Marjo Mela (ed.), Janis ja Elli Rozentāls - - elämää ja taidetta. [Janis and Elli Rozentāls - - Life and Art.] [Helsinki:] Rozentālsseura.

Leino-Kaukiainen, Pirkko 1992: Aikakauslehdistön itsenäistymisvuodet 1918-1955. [Magazines: The Years of Gaining Independence 1918-1955.] In: Päiviö Tommila et al. (eds), Aikakauslehdistön historia. Aikakauslehdistön kehityslinjat. [The History of Magazines. The Lines of Development of the Magazine.] Suomen lehdistön 
historia 10. [The History of Finnish Press 10.] Kuopio: Kustannuskiila.

Leppänen, Katarina 2009: The Conflicting Interests of Women's Organizations and the League of Nations on the Question of Married Women's Nationality in the 1930s. NORA - Nordic Journal of Feminist and Gender Research 17:4.

Leskelä-Kärki, Maarit 2006: Kirjoittaen maailmassa. Krohnin sisaret ja kirjallinen elämä. [The Krohn Sisters: Lives in Writing.] Helsinki: Suomalaisen Kirjallisuuden Seura.

Linnap, Peeter 2010: Eesti fotograafiast 1900-1940. [Estonian Photography 19001940.] In: Mart Kalm (ed.), Eesti kunsti ajalugu - History of Estonian Art 5. 1900 1940. Tallinn: Eesti Kunstiakadeemia.

Lohi, Jyrki 2005: Väinö Hämäläinen. Taidemaalarin elämä. [Väinö Hämäläinen. The Life of a Painter.] Helsinki: Suomalaisen Kirjallisuuden Seura.

Lyytikäinen, Pirjo 1997: Narkissos ja sfinksi. Minä ja Toinen vuosisadanvaihteen kirjallisuudessa. [Narcisse and the Sphinx. Self and Other in Fin-de-siècle Finnish Literature.] Helsinki: Suomalaisen Kirjallisuuden Seura.

Lyytikäinen, Pirjo 2003: The Allure of Decadence. French Reflections in a Finnish Looking Glass. In: Pirjo Lyytikäinen (ed.), Changing Scenes. Encounters between European and Finnish Fin de Siècle. Studia Litteraria Fennica I. Helsinki: Suomalaisen Kirjallisuuden Seura.

Martta Helminen 1999. Martta Helminen. Hiekan taidemuseo 7.10.-19.12.1999. [Martta Helminen. Hiekka Art Museum, 7 October - 19 December 1999.] Text by Anna Eskola \& Anne Paldanius. Hiekan taidemuseo, Tampereen taidemuseo - - Pirkanmaan aluetaidemuseo, Tampereen Taiteilijaseura ry. Julkaisu 3. Tampere: Hiekan taidemuseo.

Mela, Marjo (ed.) 2006: Janis ja Elli Rozentāls - - elämää ja taidetta. [Janis and Elli Rozentāls - - Life and Art.] [Helsinki:] Rozentāls-seura.

Melkas, Kukku 2006: Historia, halu ja tiedon käärme Aino Kallaksen tuotannossa. [History, Desire, and the Serpent of Knowledge in the Works of Aino Kallas.] Helsinki: Suomalaisen Kirjallisuuden Seura.

Nevalainen, Juha 30 October 1949: Ihminen katsoo taakseen. Aino Kallasta tapaamassa. [A Retrospective View of Life. A Meeting with Aino Kallas.] Helsingin Sanomat.

Nirk, Endel 1977: Kaanekukk. Lugu Ants Laikmaa elust ja ettevõtmistest. [The Rooster on the Cover. A History of the Life and Endeavours of Ants Laikmaa.] Tallinn: Kunst.

Olesk, Sirje 2009: Aino Kallas - - Virolainen kirjailija? [Aino Kallas - - An Estonian Author?] In: Maarit Leskelä-Kärki, Kukku Melkas \& Ritva Hapuli (eds), Aino Kallas. Tulkintoja elämästä ja tuotannosta. [Aino Kallas. Interpretations of Life and Works.] Helsinki: BTJ Kustannus.

Pakkanen, Veikko 2004: Strindberg kuvakauppiaana. [Strindberg as Reproduction Dealer.] In: Erkki Anttonen (ed.), Salon Strindberg. Helsinkiläisen taidegallerian vaiheita. [Salon Strindberg. Chapters in the History of an Art Gallery in Helsinki.] Kuvataiteen keskusarkisto 10. [Central Art Archives 10.] Helsinki: Kuvataiteen keskuarkisto.

Palin, Tutta 2007: Modernin muotokuvan merkit. Kuvia 1800- ja 1900-luvuilta Taidekoti Kirpilässä. [Signs of the Modern Portrait. 19th and 20th Century Images in the Kirpilä Art Collection]. Taidekoti Kirpilän julkaisuja 4. [Publications of the Kirpilä Art Collection 4.] Helsinki: Suomen Kulttuurirahasto.

Parente-Čapková, Viola 1998: Decadent New Woman? NORA - - Nordic Journal of Women's Studies 6:1.

Paris, Rud 1932: Konrad Mägi. Tartu: Roosi kirjastus.

Pihlak, Evi 1979: Konrad Mägi. Tallinn: Kunst.

Pujāte, Inta 1990: Janis Rozentāls. Rīga: Liesma.

Pütsep, Ervin 1991: Kunstielu Eestimaal I. Kuni 1920. aastani. [Art Life in Estonia I. Until 1920.] Studia Baltica Stockholmiensia 7. Stockholm: Almqvist \& Wiksell 
international.

Rewald, Sabine 2006: “I Must Paint You!” In: Sabine Rewald (with essays by Ian Buruma \& Matthias Eberle), Glitter and Doom: German Portraits from the 1920s. New York / New Haven \& London: The Metropolitan Museum of Art / Yale University Press.

Räty, Leena (ed.) 1990: Kalle Kuutola. Unohdettu kubisti. Etelä-Karjalan taidemuseossa 16.2.-25.3.1990. [Kalle Kuutola. A Forgotten Cubist. South Karelia Art Museum, 16 February - 25 March 1990.] Lappeenranta: Etelä-Karjalan taidemuseo.

Saraste, Leena 2004: Valo, muoto vai elämä. Kameraseurat kohti modernia 1950-luvulla. [Light, Composition or Life. Art Photography in Finland in the Mid 20th Century.] Kuvista sanoin 7 / Suomen valokuvataiteen museon julkaisuja 18. [Publications of the Finnish Museum of Photography 18.] Helsinki: Musta Taide \& Suomen valokuvataiteen museo.

Sisask, Kaia 2009: Noor-Eesti ja esprit fin-de-siècle. Puhta kunsti kreedo maailma- ja inimesetunnetust restruktureeriv roll 20. sajandi alguse Eestis. [The Noor-Eesti Movement and Esprit Fin-de-Siècle. The Role of Literary Aestheticism in Estonia at the Beginning of the 20th Century.] Humanitaarteaduste dissertatsioonid - - Dissertations on Humanities. Tallinn: Tallinn University.

[Tandefelt, Signe] (S. T-lt) 2 December 1920: Porträttmåleri. [Portrait Painting.] Hufvudstadsbladet.

Teder, Kaljula 1972: Eesti fotograafia teerajajaid. Sada aastat (1840-1949) arenguteed. [Pioneers of Estonian Photography. A Hundred Years (1840-1949) of Development.] Tallinn: Eesti Raamat.

Thauvón-Suits, Aino 1964: Gustav Suitsu noorus. Kirjade, luuletuste ja mälestuste põhjal. [The Early Life of Gustav Suits. Based on Letters, Poems and Memories.] Lund: Eesti Kirjanike Kooperatiiv.

Tihinen, Juha-Heikki 2008: Halun häilyvät rajat. Magnus Enckellin teosten maskuliinisuuksien ja feminiinisyyksien representaatioista ja itsen luomisesta. [The Uneasy Borders of Desire. Magnus Enckell's Representations of Masculinities and Femininities and the Question of How to Create the Self.] Taidehistoriallisia tutkimuksia - Konsthistoriska studier 37. [Studies in Art History 37.] Helsinki: Taidehistorian seura.

Tiik, Vaike 1972: Eesti kunst ja "Noor-Eesti” [Estonian Art and "Noor-Eesti”.] In: Tartu Riikliku Kunstimuuseumi Almanahh III. [Almanac of The National Art Museum of Tartu III.] Tartu: Tartu Riiklik Kunstimuuseum.

Urban, Otto M. 2006: In Morbid Colours: Art and the Idea of Decadence in the Bohemian Lands, 1880-1914. Prague: Municipal House \& Arbor Vitae Press.

Verhagen, Marcus 1995: The Poster in Fin-de-Siècle Paris: "That Mobile and Degenerate Art". In: Leo Chamey \& Vanessa Schwartz (eds), Cinema and the Invention of Modern Life. Berkeley: University of California Press.

Vollmer, H.[ans] 1910: Boubong, Antonie. In: Ulrich Thieme \& Felix Becker (eds), Allgemeines Lexikon der Bildenden Künstler von der Antike bis zur Gegenwart 4. Leipzig: Wilhelm Engelmann.

Vuorikuru, Silja (ed.) 2008: Elämisen taiteesta. Aino Kallaksen ja Anna-Maria Tallgrenin kirjeenvaihtoa kolmelta vuosikymmeneltä. [On the Art of Life. Correspondence between Aino Kallas and Anna-Maria Tallgren from Three Decades.] Helsinki: Otava.

Waga, Alfred 1938: Ants Laikmaa. Tallinn: Kultuurkoondis.

Wichstrøm, Anne 2000: Gendered Representation. Asta Nørregaard's Upper-Class Portraiture 1890-1905. Konsthistorisk Tidskrift LXIX:1.

Willner-Rönnholm, Margareta 2004: Under traditionens täckmantel. Kvinnliga banbrytare i modernismens konstkultur i Åbo. [Tradition as Camouflage. Women Pioneers in the Modernist Art Culture of Turku.] In: Tutta Palin (ed.), Modernia on moneksi. Kuvataiteen, taideteollisuuden ja arkkitehtuurin piirteitä maailmansotien välisen ajan Suomessa - - Det moderna är mångahanda. Texter om bildkonst, 
konstindustri och arkitektur mellan första och andra världskrigen i Finland. [Many Kinds of Modern. Features of Visual Art, Applied Art and Architecture of the Inter-War Years in Finland]. Taidehistoriallisia tutkimuksia - - Konsthistoriska studier 29. [Studies of Art History 29.] Helsinki: Taidehistorian seura.

\section{Electronic sources}

Asmer, Vilve 1998: Esimestest piltnikest Eestimaal ja nende fotodest Eesti Kultuuriloolises Arhiivis (1844-1900), 11.2.1998 [The First Estonian Photographers and Photos Made by Them in the Estonian Archive of Cultural History (1844-1900), 11.2.1998], available at: http://www.kirmus.ee/Asutus/Valjaanded/ekmar/esimest. html\#Nyblin (13 August 2009).

A Brief History of the Lafayette Photographic Studios s.a. In: Lafayette Photography (Dublin), available at: http://www.lafayette.ie/html/history.htm (30 September 2009).

Honkonen, Päivi (ed.) 2001: Verkkonäyttelyn valokuvaajat [The Photographers of the Virtual Exhibition]. In: Sumusta sommitteluun - - From Misty Morning to Composition - - Från morgondimma till komposition. Taidevalokuvauksen käänteitä sodanjälkeisessä Suomessa (an exhibition curated by Leena Saraste for The Finnish Museum of Photography, Helsinki; internet version of the exhibition by Päivi Honkonen), available at: http://www.fmp.fi/sumusta/esitt/kuvaajat.htm (30 September 2009).

Hoppé, Emil Otto, 1878-1972, Photographer and Writer 2004. In: RCS Photographers Index (Cambridge University Library) available at: http://www.lib.cam.ac.uk/rcs_ photographers/entry.php?id=248 (30 September 2009).

Kivimäe, Juta 2000: Viitoli realistlikud portreed [Viitol's Realistic Portraits], available at: http://www.sirp.ee/2000/11.08.00/Uudis/uudis1-1.html (28 July 2009).

Raitar, Maie 27 November 1998: Naised Konrad Mäe elus ja kunstis. [Women in the Life and Art of Konrad Mägi.] Eesti Ekspress, available at: http://paber.ekspress. ee/arhiiv/1998/48/Areen/Kunst.html (30 September 2009).

Salo, Merja 2005: Muodin ikuistajat: muotivalokuvaus Suomessa. Biografiat. [Making Fashion Eternal: Fashion Photography in Finland. Biographies.] In: Uutuuksia (Suomen valokuvataiteen museo, Helsinki) [New Items (Finnish Museum of Photography, Helsinki)], available at: http://www.fmp.fi/fmp_fi/muvieras/mukauppa/ liitteet/muodin_ikuistajat_biografiat.htm (30 September 2009).

Savia, Tyyne Elisabeth s.a. In: Valokuvaajat 1839- (Suomen valokuvataiteen museo, Helsinki) [Photographers 1839- (Finnish Museum of Photography, Helsinki)], available at: http://www.valokuvataiteenmuseo.fi/fi/tietopalvelu/valokuvaajat/9403-savia-tyyne-elisabeth (30 September 2009).

Swaine, F A, fl 1919-1938, Photographer 2004. In: RCS Photographers Index (Cambridge University Library), available at: http://www.lib.cam.ac.uk/rcs_photographers/entry.php?id=437 (30 September 2009).

Tiik, Vaike 1996: Ants Laikmaa portreed tartlastest. Kunstniku 130. sünniaastapäeva puhul [Portraits of Citizens of Tartu by Ants Laikmaa. On the Occasion of the Artist's $130^{\text {th }}$ Anniversary], available at: http://luup.postimees.ee:8080/leht/96/05/08/ kultuur.htm\#kolmas (29 October 2008).

Wrightson, Hay, fl 1920-1929, Photographer 2004. In: RCS Photographers Index (Cambridge University Library), available at: http://www.lib.cam.ac.uk/rcs_photographers/entry.php?id=489 (30 September 2009). 


\section{Contributors}

Ritva Hapuli, PhD, is a Docent at the Department of Cultural History at the University of Turku. She has recently conducted research on the texts of Finnish female travellers and published two monographs on the subject: Ulkomailla. Maailmansotien välinen maailma suomalaisnaisten silmin [Abroad. The World between the two World Wars seen by Finnish Women] (2003) and Matkalla kotona. Kyllikki Villan matkapäiväkirjoista [Travel - A Way of Being at Home. About Kyllikki Villa's travel diaries] (2008). She is now focusing on travelogues as eyewitness testimonies.

Mirjam Hinrikus, MA, is a PhD student of Estonian literature at the University of Tartu and a Researcher at the Under and Tuglas Literature Centre of the Estonian Academy of Sciences. Her dissertation focuses on the analysis of decadence and anti-feminism in the work of A.H. Tammsaare, J. Randvere's essay "Ruth" and F. Tuglas' novel Felix Ormusson. She has edited two volumes in the series "Seminar in Modern Estonian Literature" focusing on key texts of Estonian literature, J. Randvere "Ruth" 19.-20. sajandi vahetuse kultuuris. [J. Randvere's "Ruth" in the Context of the Turn of the $19^{\text {th }}$ Century] (2006) and with J. Undusk, Armastus ja sotsioloogia. A. H. Tammsaare romaan "Ma armastasin sakslast" [Love and Sociology. A. H. Tammsaare's Novel I loved a German] (forthcoming in 2011).

TiIna Kirss is currently the Professor of Cultural Theory at the Estonian Institute of Humanities, Tallinn University. Her primary research interests are 20th century comparative European literary history, autobiography and life stories, oral history, and cultural translation. She has published on Siberian deportations in the Baltics, trauma theory, the European historical novel, postcolonialism and modernisms, diaspora-homeland literary relations, and feminist theory. Her most recent publications include Estonian Life Stories (CEU Press 2009)and articles on the core texts of the Estonian autobiographical tradition.

Leena Kurvet-Käosa ar, PhD, is an Associate Professor of Comparative Literature at the Estonian Institute of Humanities, Tallinn University and a Senior Researcher of the Estonian Cultural History Archives, Estonian Literary Museum. Her main research interests are culture and literature of the period of modernity and different periods and textual practices of life writing, including women's life writing, Post-Soviet life writing, corporeality and life writing, and the diary. Her doctoral dissertation titled Embodied Subjectivity in the Diaries of Virginia Woolf, Aino Kallas and Anaïs Nin was published in 2006. She is the holder of ESF grant "Life Writing on Estonian 
Literary Landscapes" (2008-2011) and the editor of recent special issue of Methis on Estonian life writing (5/6 2010).

MaARIt Leskelä-Kärki, PhD, works as a Post-Doctoral Researcher at the Turku Institute for Advanced Studies and at the Department of Cultural History. Her thesis Kirjoittaen maailmassa. Krohnin sisaret ja kirjallinen elämä [The Krohn sisters: Lives in Writing], (2006) analysed the literary lives of Aino Kallas and her two sisters. She has also edited a collection of articles on Aino Kallas (Aino Kallas. Tulkintoja elämästä ja tuotannosta, 2009), and is the chair of Aino Kallas Society, established in 2006. Her current research focuses on women's biographical traditions during the last century. She has published several articles on biographical research, epistolary practises and women writers.

Liina Lukas, PhD, is an Associate Professor of Comparative Literature at the Institute of Cultural Research and Fine Arts, University of Tartu and a Senior Reseacher at the Under and Tuglas Literature Centre of the Estonian Academy of Sciences. She is the leader of the web-based research Project of Estonian older literature EEVA and leader of Estonian Goethe Society. Main areas of research: Estonian-German literary contacts, Baltic-German literature, older Estonian literature.

Kukku Melkas, PhD, works as a lecturer at the Department of History, Culture and Art Studies at the University of Turku. Her thesis: Historia, halu ja tiedon käärme Aino Kallaksen tuotannossa [History, Desire and the Serpent of Knowledge in the Works of Aino Kallas] was published in 2006. She has also written about the significance of the figure of the maid in Finnish literature in Läpikulkuihmisiä. Muotoiluja kansallisuudesta ja sivistyksestä 1900-luvun alun Suomessa. [The Passage People. Formations of Nationality and Civility in Finland in the Beginning of the 20th Century] (2007).

SiRJE Olesk, PhD, is a Senior Researcher of the Estonian Cultural History Archives, Estonian Literary Museum. Her main research interests include different periods of Estonian literature and Estonian-Finnish cultural relations. She is the co-author of Eesti kirjanduslugu [Estonian Literature] (2001) and has published articles and monographs on the life and work of Lydia Koidula, Marie Under, Aino Kallas and edited various ego-documents (diaries, correspondences) of Estonian cultural figures (Ivar Ivask, Ants Oras, Oskar Loorits). She is the co-editor, with Seppo Zetterberg of the volume Kultuurisild üle Soome lahe. Eesti ja Soome akadeemilised ja kultuurisuhted 1918-1944 [Cultural Bridge across the Gulf of Finland. EstonianFinnish Academic and Cultural Relations 1918-1944] (2005).

Tutta Palin, PhD, a Docent, works as an Academy Research Fellow, funded by the Academy of Finland, at the Department of Art History at the University of Turku. This article contributes, on her part, to her ongoing research project "Experiments with Figurative Art in Early $20^{\text {th }}$ Century Finland" that explores dimensions of artistic and social experimentation 
in mainstream Modernism. Her previous publications include two monographs on $19^{\text {th }}$ and $20^{\text {th }}$ century portrait painting in Finland: Oireileva miljöömuotokuva [The Symptomatics of the Milieu Portrait] (2004), and Modernin muotokuvan merkit [Signs of the Modern Portrait] (2007).

Lea Rojola is the Professor of Finnish Literature at the Department of History, Culture and Art Studies at the University of Turku. Her research interests include modernism in Finnish literature, feminist theory and Finnish women's writing. She is the author of several volumes on Finnish literature, literary theory and gender issues, editor of Suomen kirjallisuushistoria. 2, Järkiuskosta vaistojen kapinaan [Finnish Literary History II: From Belief in the Mind to a Rebellion of Insticts] (1999) and (with Päivi Lappalainen) Women's Voices. Female Authors and Feminist Criticism in the Finnish Literary Tradition (2006), and the co-editor of Läpikulkuihmisiä. Muotoiluja kansallisuudesta ja sivistyksestä 1900-luvun alun Suomessa. [The Passage People. Formations of Nationality and Civility in Finland in the Beginning of the 20th Century] (2007).

Kai Stahl, MA, is a PhD student at the Department of Art History at the University of Turku. Her doctoral thesis project focuses on Natalie Mei's artworks from the perspective of female agency and modernisation during the 1910s to the 1930s. Her recent publications include "Prostituutiokuva kulttuurikentän rajan ylityksenä” [Images of Prostitution: Crossing the Border of Cultural Fields], (2010).

Rein Undusk, MA, is a Researcher at the Under and Tuglas Literature Centre of the Estonian Academy of Sciences. He has published on the Estonian literary classics and on the conceptual history of literary theory. He is currently working on the topic of infinity in philosophy and arts. He has edited the volume At the End of the World: Text, Motif, Culture (2005).

Silja Vuorikuru, MA, is a PhD student at the Department of Finnish, Finno-Ugrian and Scandinavian Studies at the University of Helsinki. Her doctoral thesis focuses on the intertextuality of Aino Kallas' oeuvre, in particular on the Bible as a general subtext in Kallas' works from the 1910s to the 1940s. Her recent publications include: "Aino Kallase tundmatu näidend Batseba" [Aino Kallas' Unknown Play Batseba], Keel ja Kirjandus 3/2009 and Elämisen taiteesta. Aino Kallaksen ja Anna-Maria Tallgrenin kirjeenvaihtoa kolmelta vuosikymmeneltä [The Art of Living. The Correspondence Between Aino Kallas and Anna-Maria Tallgren on three decades.] (2008). 


\section{Studia Fennica Ethnologica}

\author{
Making and Breaking \\ of Borders \\ Ethnological Interpretations, \\ Presentations, Representations \\ Edited by Teppo Korhonen, \\ Helena Ruotsala \& \\ Eeva Uusitalo \\ Studia Fennica Ethnologica 7 \\ 2003
}

Memories of My Town

The Identities of Town Dwellers

and Their Places

in Three Finnish Towns

Edited by Anna-Maria Åström,

Pirjo Korkiakangas \& Pia Olsson

Studia Fennica Ethnologica 8

2004

\section{Passages Westward}

Edited by Maria Lähteenmäki \&

Hanna Snellman

Studia Fennica Ethnologica 9

2006

\section{Defining Self}

Essays on emergent identities

in Russia Seventeenth

to Nineteenth Centuries

Edited by Michael Branch

Studia Fennica Ethnologica 10

2009

Touching Things

Ethnological Aspects of

Modern Material Culture

Edited by Pirjo Korkiakangas,

Tiina-Riitta Lappi \&

Heli Niskanen

Studia Fennica Ethnologica 11

2009

\section{Gendered Rural Spaces}

Edited by Pia Olsson \&

Helena Ruotsala

Studia Fennica Ethnologica 12 2009

\section{Studia Fennica Folkloristica}

Creating Diversities

Folklore, Religion and the Politics

of Heritage

Edited by Anna-Leena Siikala,

Barbro Klein \&

Stein R. Mathisen

Studia Fennica Folkloristica 14 2004

\section{Perti J. Anttonen \\ Tradition through Modernity \\ Postmodernism and the Nation- \\ State in Folklore Scholarship \\ Studia Fennica Folkloristica 15 \\ 2005}

Narrating, Doing, Experiencing

Nordic Folkloristic Perspectives

Edited by

Annikki Kaivola-Bregenhøj,

Barbro Klein \& UIf Palmenfelt

Studia Fennica Folkloristica 16

2006

MíchÉAL BRIOdY

The Irish Folklore Commission

1935-1970

History, ideology, methodology

Studia Fennica Folkloristica 17

2007

\section{Studia Fennica Historica}

Medieval History Writing and Crusading Ideology

Edited by

Tuomas M. S. Lehtonen \& Kurt Villads Jensen with Janne Malkki and Katja Ritari Studia Fennica Historica 9 2005

Moving in the USSR

Western anomalies

and Northern wilderness

Edited by Pekka Hakamies

Studia Fennica Historica 10

2005

Derek Fewster

Visions of Past Glory

Nationalism

and the Construction

of Early Finnish History

Studia Fennica Historica 11

2006

Modernisation in Russia

since 1900

Edited by Markku Kangaspuro

\& Jeremy Smith

Studia Fennica Historica 12

2006

Seija-Riltta LaAkso

Across the Oceans

Development of Overseas

Business Information

Transmission 1815-1875

Studia Gennica Historica 13

2007

Industry and Modernism

Companies, Architecture

and Identity in the Nordic

and Baltic Countries during the

High-Industrial Period

Edited by Anja Kervanto

Nevanlinna

Studia Fennica Historica 14

2007 


\section{Studia Fennica Linguistica}

Charlotta WolfF

Noble conceptions of politics

in eighteenth-century Sweden

(ca 1740-1790)

Studia Fennica Historica 15

2008

Sport, Recreation and Green

Space in the European City

Edited by Peter Clark,

Marjaana Niemi \& Jari Niemelä

Studia Fennica Historica 16

2009

Rhetorics of Nordic Democracy

Edited by Jussi Kurunmäki \&

Johan Strang

Studia Fennica Historica 17

2010

The use of pronouns in Finnish
Minna SaArelma-MaunumaA

Edhina Ekogidho -

Names as Links

The Encounter between African

and European Anthroponymic

Systems among the Ambo People

in Namibia

Studia Fennica Linguistica 11 2003

Minimal reference and Estonian discourse

Edited by Ritva Laury

Studia Fennica Linguistica 12 2005

\section{AnTtI LEINO \\ On Toponymic Constructions as an Alternative to Naming \\ Patterns in Describing \\ Finnish Lake Names \\ Studia Fennica Linguistica 13 \\ 2007 \\ Talk in interaction \\ Comparative dimensions \\ Edited by Markku Haakana, Minna Laakso \& Jan Lindström Studia Fennica Linguistica 14 2009}

Planning a new
standard language
Finnic minority languages meet
the new millennium
Edited by Helena Sulkala \&
Harri Mantila
Studia Fennica Linguistica 15
2010

\section{Studia Fennica Litteraria}

\section{Changing Scenes}

Encounters between European and Finnish Fin de Siècle

Edited by Pirjo Lyytikäinen

Studia Fennica Litteraria 1

2003

\author{
Women's Voices \\ Female Authors \\ and Feminist Criticism \\ in the Finnish Literary Tradition \\ Edited by Lea Rojola \& \\ Päivi Lappalainen \\ Studia Fennica Litteraria 2 \\ 2007 \\ Metaliterary Layers \\ in Finnish Literature \\ Edited by Samuli Hägg, \\ Erkki Sevänen \& Risto Turunen \\ Studia Fennica Litteraria 3 \\ 2009
}

\section{Studia Fennica Anthropo- logica}

On Foreign Ground

Moving between Countries

and Categories

Edited by Minna Ruckenstein \& Marie-Louise Karttunen

Studia Fennica Anthropologica 1 2007

Beyond the Horizon

Essays on Myth, History,

Travel and Society

Edited by Clifford Sather \&

Timo Kaartinen

Studia Fennica Anthropologica 2 2008 